
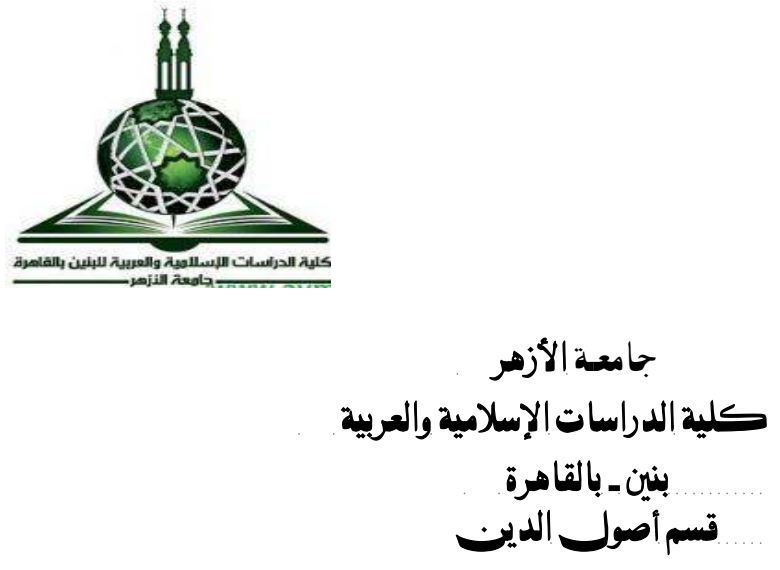

\title{
فلســفة الحـــزنت
}

《دراسة

\section{إعــــلـاد}

محمــل على منصــور مزروعـة

المدرسبكليةالدراسات الإسلاميةوالعربية

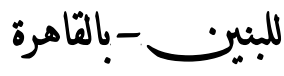

$$
\text { A r.17-ه - Drr }
$$




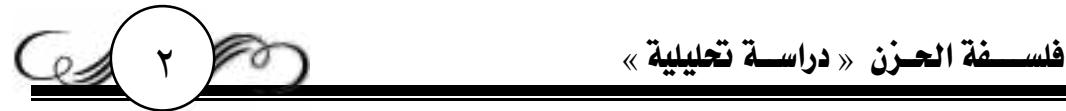

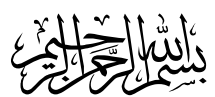

\section{المقدمـــــة}

الحمد لله رب العالمين، والصلاة والسلام على أفضل الأنبياء والمرسلين نبينا محمد، وعلى آله وصحبه والتابعين لهم بإحسان إلى يوم الدين.

\section{أمسا بعــــد}

إنَّ الله سبحانه وتعالى خلق النفس الإنسانية وسو اها في أحسن تقويم، وأودع

فيها بجموعة من المشاعر والانفعالات ، تتجلى في ما يطرأ عليها من تغيرات فسيولوجية داخلية ، وتعبيرات جسمية خارجية .

وإذا كانت المشاعر والانفعالات هي المسؤولة عن الحالة النفسية والمزاجية

للإنسان ، فمن المهم للشخص أن يكتسب مهارات التعبير عن هذه الانفعالات بطريقة إيمابية .

ومن بين تلك المشاعر المستقرة في النفس ، وهذه الانفعالات المتوطنة ، شعور

الحزن الذي يصيب الإنسان بين الحين والآخر؛بسبِ الدواخل والعوارض المصاحبة له ، ويُعَدُ من الانفعالات ذات العو اقب الوخيمة ، التي تسبب الكثير من لئب الأمراض العضوية والنفسية ، خاصة وأن كثيرًا من الناس ليس لديهم من

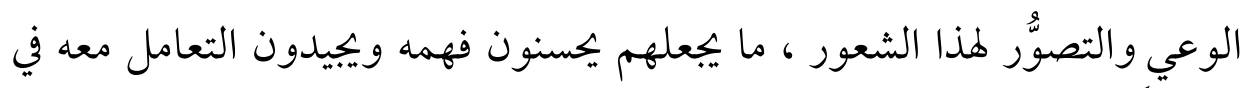
حدود الفهم الصحيح المشروع ·

ومن الحكمة الإلهية ، واللطائف الربانية ، أن جعل هذا الانفعال من المشاعر 


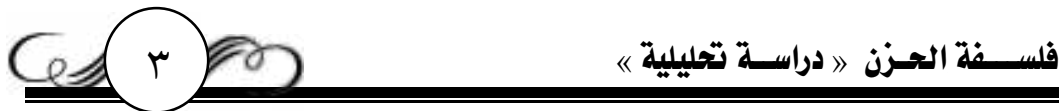

التي تتناوب في التفاعل مع الإنسان على وجه العارض لا على وجه الديمومة ، وإلا لملك الإنسان بدوام الحال، فما هو إلا ألم يلحق بالنفس؛ وهذا لم يأت في القرآن

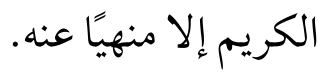

ولقد اهتم الدين الإسلامي بالجانب النفسي، وأولى القرآن الكريم تلك القضية عناية خاصة، وهذا ما دفع علماء المسلمين إلى الاهتمام به خاصة وبعلم النفس عامة، فكان لهم إسهامات قيمة في الدراسات النفسية أثرت تأثيرًا كبيرًا في

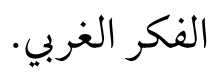

ولما كان الحزن من أكثر الأمراض النفسية انتشارًا ، فقد دعت الحاجة دراسته- لمعرفة: الأسباب الحقيقية للحزن، وموقف الإسلام منه، وآثاره على الإنسان، وكيف عالجه الإسلام- وكان ذلك تحت عنو ان:فلسفة الحزن دراسة تحليلية * سبب اختيار هذا الموضوع .

لقد كان وراء اختياري لهذا الموضوع بو اعث ودوافع كثيرة تآزرت وتعاونت على دفعي لاختياره، أهمها : أولاً : كشف اللثام عن الأسباب الحقيقية وراء سقوط المرء فريسة في شباك

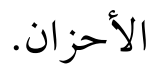

ثانياً : الرغبة في بيان براعة الدين الإسلامي وتفوقه في مساعدة الإنسان وتخليصه من داء الحزن الخبيث. 


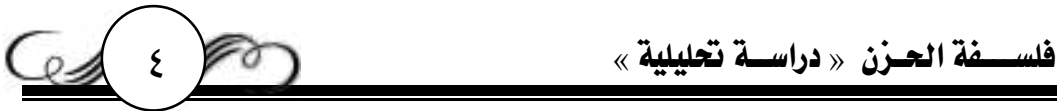

ثالثاً : التنبيه على خطر الانفعالات - خاصة الحزن- على حالة الإنسان النفسية

$$
\text { والجسدية. }
$$

رابعًا : التعرف على آراء واتجاهات وتشخيصات مختلفة - في هذه الحالة - وسبل الخلاص منها.

خامسًا : تكوين صورة صحيحة عن الإنسان وحياته النفسية في التراث الإسلامي. سادسًا : محاولة إيياد دراسات جديدة في علم النفس ذات توجه إسلامي. سابعًا : يبرز هذا البحث فضل السبق لعلماء المسلمين على الحضارة الغربية التي قامت ونهضت على أساس من جهود هؤلاء، ليس في علم النفس فحسب،

$$
\text { بل في جميع فروع المعرفة الإنسانية. }
$$

إن المنهج هو: الطريق المؤدى إلى الكشف عن الحقيقة بواسطة طائفة من

القواعد العامة التي تهيمن على سير العقل، وتحدد عملياته حتى يصل إلى نتيجة

$$
\text { معلومة (1) }
$$

ولما كان المنطق يدرس صور الفكر وطرق الاستدلال السليم، فقد استخدم

$$
\text { "المنهج الاستنباطي"الذي فيه ينتقل الباحث من المقدمات إلى النتائج. }
$$

مناهج البحث العلمي، الدكتور/ عبد الرحمن بدوى، صـه، طبعة سنة ساج19 م، دار النهضة

$$
\text { العربية، مصر. }
$$




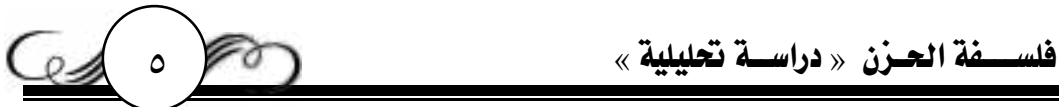

وأسس هذا المنهج الجوهرية هي التعريفات؛ لأن الباحث يبدأ بتحديد معاني

الألفاظ المستخدمة في بحثه، ودائمًا ما يتطلب هذا المنهج استخدام المناهج التالية: أ - المنهج الوصفي:ويهدف هذا المنهج إلى وصف الظواهر وصفًا دقيقًا،

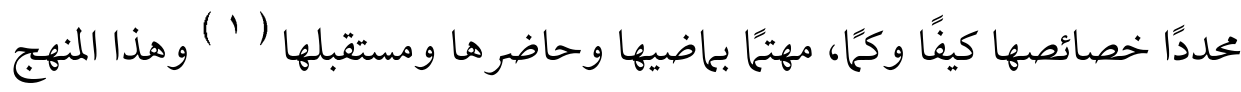
هو القائم بتحقيق وتقديم دراسة علمية للظواهر دون أن يتدخل في حدوثها، باعتباره المختص بدراسة الوضع الراهن ومحاولة تفسير هذا الوضع · ب- المنهج التحليلي:الذي يعنى بتفسير النصوص والآراء الخاصة بالموضع، وتحليلها تحليلًا دقيقًا يجلو الغموض عنها.

ج- كما استخدم الباحث المنهج الذاتي أو الاستبطاني: وهو يقوم على التأمل الباطني أو الملاحظة الداخلية، ويعتبر أقدم مناهج علم النفس وأهمها؛ لكون الحالات الشعورية داخلية لا خارجية مادية، يختبرها الفرد بنفسه، ويحس بها إحساسًا مباشرًا ( r ) فجوهر هذا المنهج هو الملاحظة الذاتية، حيث يقوم الفرد بملاحظة ذاته، وينقسم في ذات الوقت إلى ملاحظ وملاحَظ، فهو الذي يرصد ما يدور بداخله من أفكار ومشاعر وانفعالات، وهو الذي يحدثنا عنها .

(') مناهج البحث الفلسفي، الدكتور/ محمد أحمد مصطفى السرياقوس، صـآ، طبعة سنة

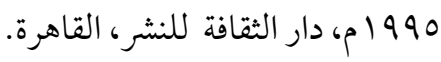

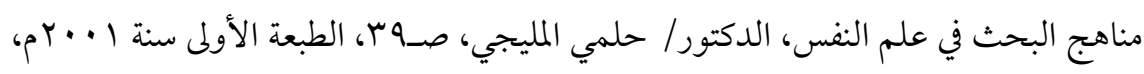

$$
\text { بيروت - لبنان. }
$$




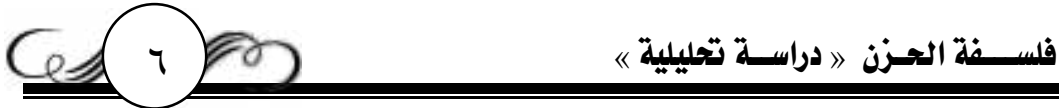

هذه هي المناهج المستخدمة في البحث، أما عرض هذا الموضوع ومعالجته

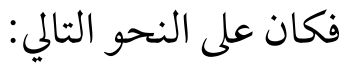

يدور محور هذا البحث في الدرجة الأولى حول ما يعتري الإنسان من أحزان،

وأن ثمة عو امل هي المسئولة عن ذلك، يجب الخلاص منها.

وحول هذه الفكرة قامت دعائم هذا البحث، لتثبت آراء علماء المسلمين في

هذه القضية، وما جاء به الوحي الشريف، وكيفية تخليص الإنسان من مشاعر الحزن و الكآبة، وذلك في جد وتركيز وتسلسل وترابط، كمقدمات منطقية ضرورية لهذه

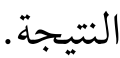

فالفصل الأول وهو يتحدث عن ماهية الحزن، وتعريفاته المختلفة عند علماء المسلمين على اختلاف آرائهم واتجاهاتهم، يجمل في طياته ما يدلل على المعنى الحقيقي للحزن عند الفلاسفة وعلماء النفس والصوفية، كما يتناول التمهيد شرح وتفصيل للأوصاف والمرادفات المختلفة لكلمة حزن، والفروق اللغوية بينهم، ثم تصنف هذه الحقول الدلالية حسب قوتها وعمقها، وتأثيرها في النفس، من الأدنى

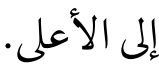

أما الفصل الثاني، فالمبحث الأول فيه يميط اللثام عن حو افز وبو اعث انفعال الحزن والأسى؛ لأن كل ألم لا يعرف سببه لا يرجى شفاؤه، كما يقول فيلسوف العرب"أبو يوسف يعقوب بن إسحاق الكندي" في رسالته "الحيلة لدفع الأحزان"أما موقف الإسلام من هذا الداء، فهو محور المبحث الثاني، وموقف 


\section{Ces $V$}

الإسلام يتجلى من خلال القرآن الكريم، والسنة النبوية، ومن خلال العقل و المنطق، و الفطرة السليمة، فهذه الأمور هي الميزان الذي تعتمده هذه القضية؛ لأنها ميزان عام، وشامل لا يختص بدين دون آخر أو بقوم دون سو اهم، بالإضافة إلى ذلك هي في إمكان الباحث استخدامها، وهى ملزمة للجميع، فلا يعارض فيها إلا بـان جاحد معاند، والمعاندون لا وزن لهم. فمن الذي ينكر العقل؟ وهو الملكة المميزة المدركة التي امتن الله بها على الإنسان لكي يدرك به الحق ويميز به الخبيث من الطيب؟ ومن الذي ينكر المنطق وهو الذي يخاطب الفكر؟وبمساعدة قواعده، وقضاياه، ومقدماته يصل الإنسان إلى النتيجة الصحيحة.

ومن الذي ينكر الفطرة، وهى القوة المدركة للحق ؟ فهي النور الرباني

الذي يقذفه الله في قلب الإنسان، وهى السر الإلهي الذي فطر الله الناس عليها، فإذا لم تلوث هذه الفطرة أدرك الإنسان الخير والحق واجتب الباطل.

أما الفصل الثالث، فالمبحث الأول يرصد الظواهر والآثار التي يسببها الحزن، ومدى تأثيرها على حالتي الإنسان النفسية والجسدية، وهنا يأتي دور العلاج ليسجل لنا المبحث الثاني ما جاء به الإسلام من علاج قبل الإصابة بهذا الداء ويعدها، ليكفل للبشرية كلها الاطمئنان والسعادة، ويؤكد على سبقه - بدستوريه القرآن والسنة، وعلمائه الكرام - كل النظريات والفلسفات التي جاء بها علماء النفس. 


\section{فلســة الحـزن 》 دراسـة تحليلية 《)}

أما الخاتمة فقد تضمنت خلاصة ما تو صل إليه البحث من نتائج.

ولدراسة هذا الموضوع دراسة عميقة ومركزة في ضوء هذا المنهج قسمت

البحث إلى مقدمة وثلاثة فصول وخاتمة.

فأما المقدمة والتي نحن بصددها فتتكون من أسباب اختياري للموضوع وأهميته، والمنهج المتبع فيه وخطة البحث.

و أما الفصل الأول فعنو انه: ماهية الحزن وتفصيل أوصافه.

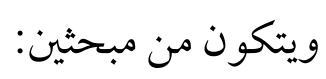

المبحث الأول: تعريف الحزن لغة واصطلاحًا.

المبحث الثاني: تفصيل أوصاف الحزن.

الفصل الثاني: أسباب ودوافع الحزن، وموقف الإسلام منه.

ويتكون هذا الفصل من مبحثين:

المبحث الأول: أسباب ودوافع الحزن.

المبحث الثاني: موقف الإسلام من الحزن.

الفصل الثالث: أعراض الحزن وآثاره، وعلاج الإسلام له

ويتكون هذا الفصل من مبحثين:

المبحث الأول: أعر اض الحزن وآثاره. 


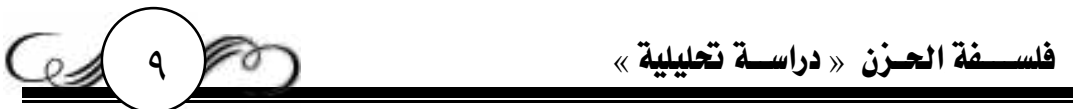

$$
\begin{aligned}
& \text { المبحث الثاني: علاج الإسلام للحزن. } \\
& \text { الخاتمة: وفيها نتائج البحث وفوائده. }
\end{aligned}
$$

هذا ولا يسع الباحث إلا أن يردد مع نبي الله سليمان اليَلِّهِ قول ربنا تبارك وتعالى :

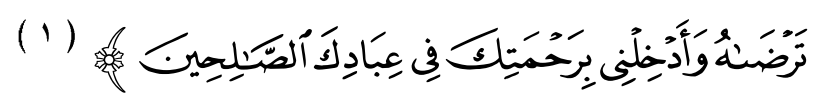




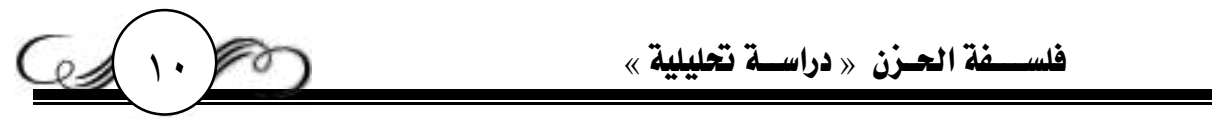

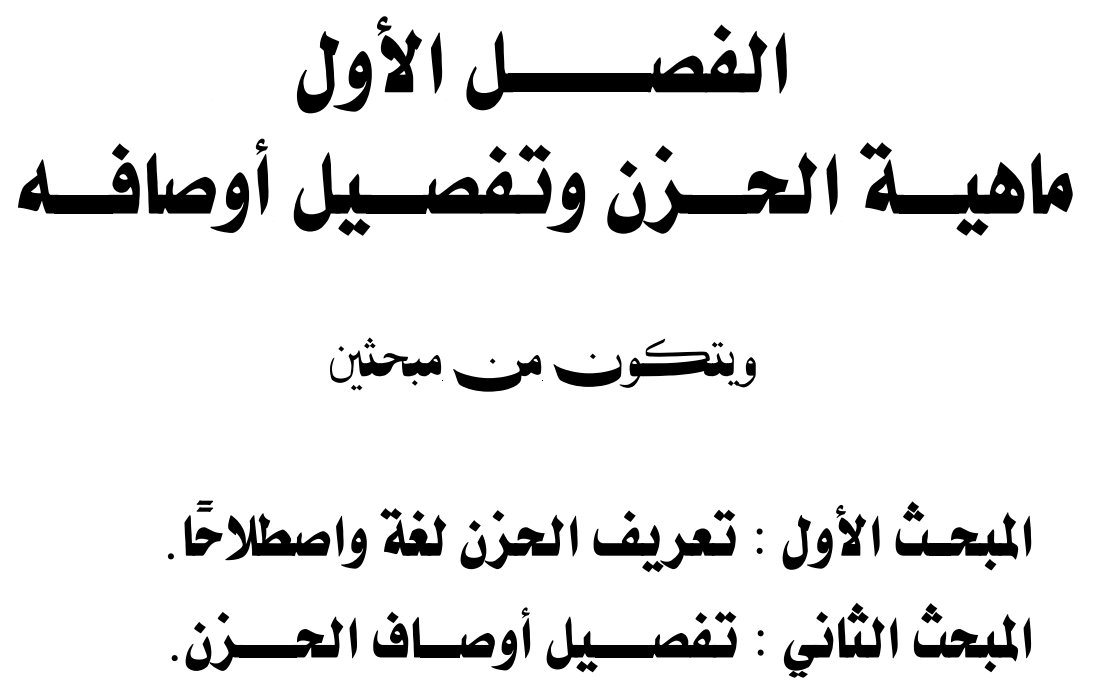




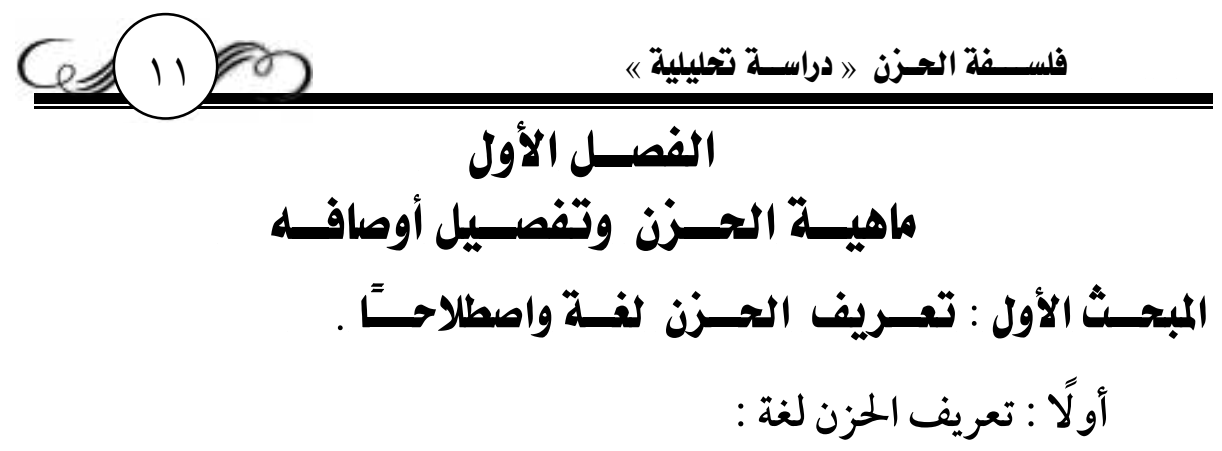

وردت مادة "حزن" وما يشتق منها في اثنين وأربعين موضعًا من القرآن

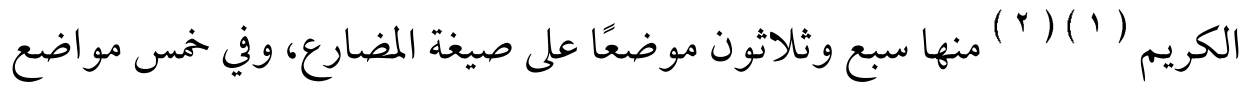

منها خمس وعشرون في آيات مكية، وسبع عشرة موضعًا في آيات مدنية، ووردت بصيغة"تخزن" ( ')

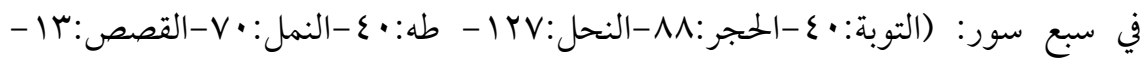

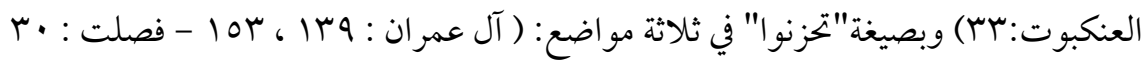

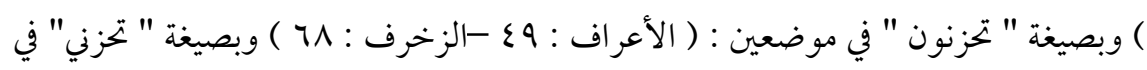

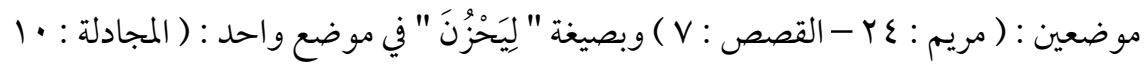

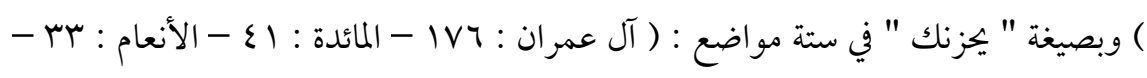

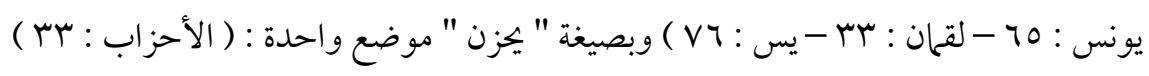

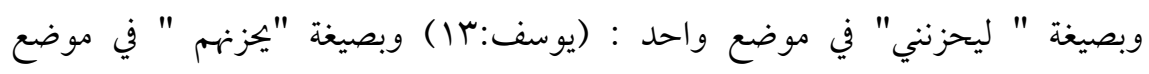

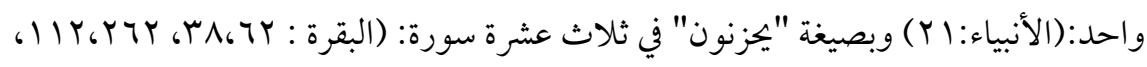

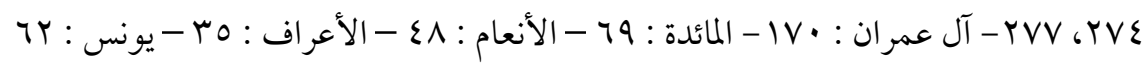

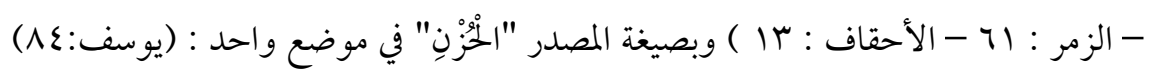

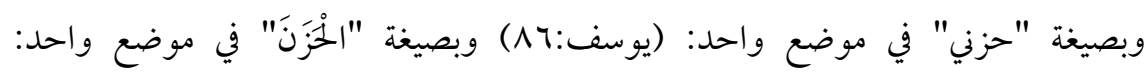

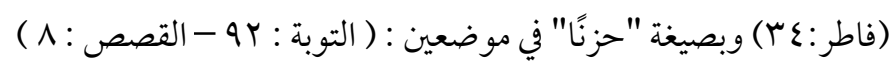

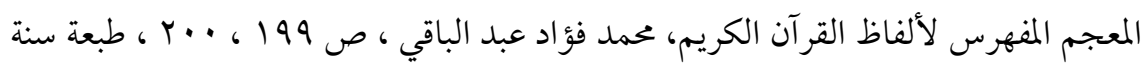

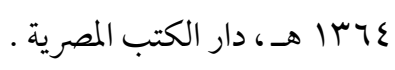




\section{Cen}

على صيغة المصدر، وقد جاءت صيغ المضارع على أسلوبي النفي والنهي؛ لتعطي دلالة الكراهية والتحذير في الحاضر والمستقبل، مع العلم بأن النهي هنا ليس على

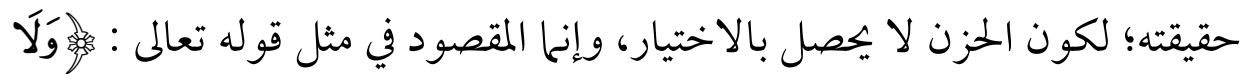

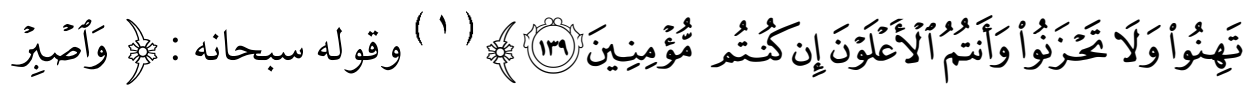

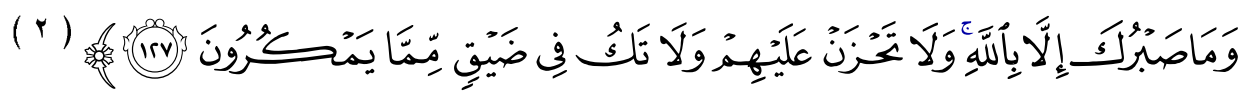
إنها هو النهي عن التعاطي والركون إلى أسبابه وإلى ما يورثه ويكسبه ( " ). أما ما جاء من هذه المادة على المصدر، فإنما يدل على مطلق الحزن، كقوله تعالى : هو

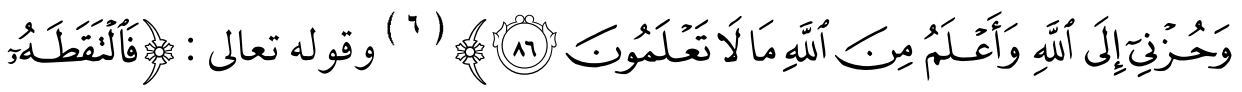

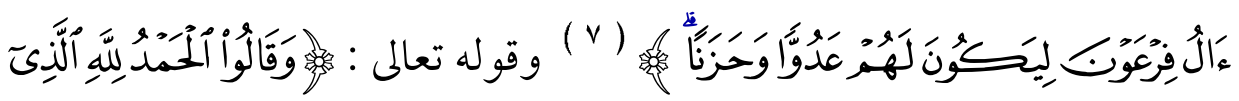

$$
\text { سورة آل عمر ان، الآية:9 س ا. }
$$

(·) انظر المفردات في غريب القرآن، الراغب الأصفهاني، صـابr، تحقيق/صفوان عدنان

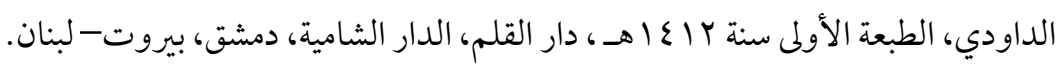

$$
\begin{aligned}
& \text { سورة التوبة، الآية:9r. } \\
& \text { سورة يوسف، الآية:ع^. } \\
& \text { سورة يوسف، الآية:11. } \\
& \text { سورة القصص، الآية:^. }
\end{aligned}
$$




\section{فلســفة الحـزن 》 دراسـة تحليلية 《)}

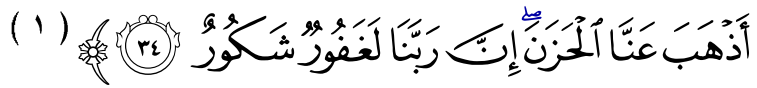

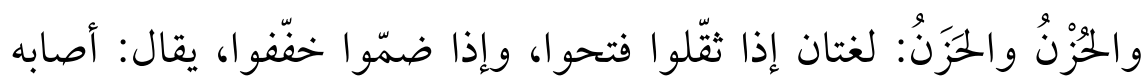

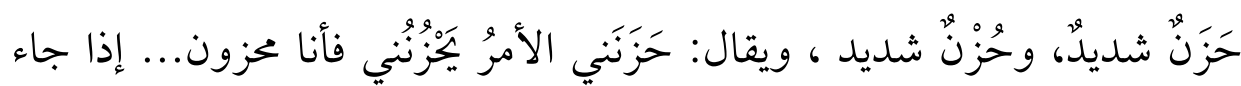
الحَزَنْ منصوباً فَتَحوه، وإذا جاء مكسوراً أو مرفوعاً ضَمَّوه، قال الله عز وجل :

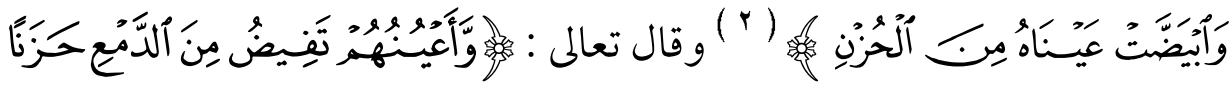

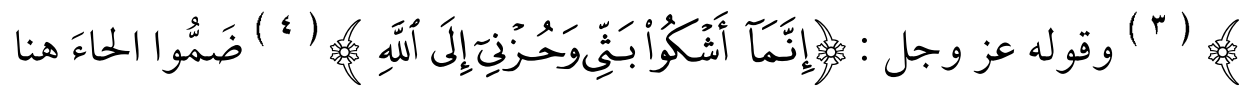

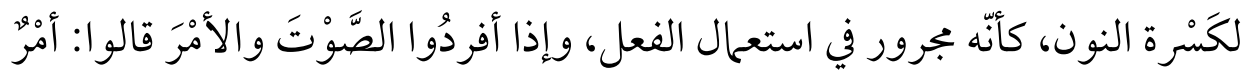

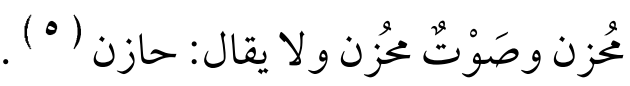

والحزْنْ: نقيضُ الفرَح وهو خلافَُ السُّرور، وقد حَزَنَ بالكسر حَزَنًا وتحازَنَ

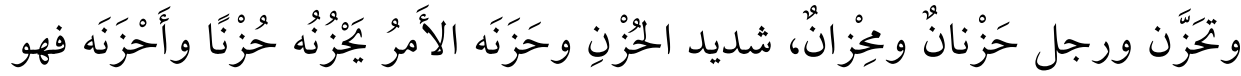

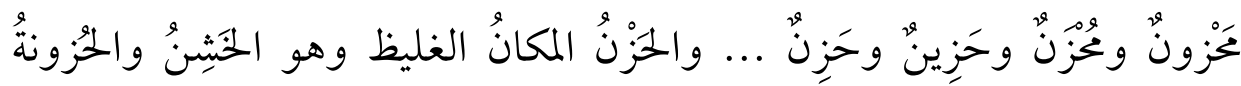

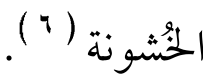

$$
\text { سورة فاطر، الآية:عـ. سورة يوسف، الآية: عـ. }
$$

العين، الخليل بن أحمد الفراهيدي، جـاصــا آم،تحقيق الدكتور / عبد الحميد الهنداوي، الطبعة

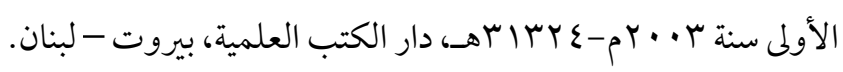

لسان العرب، محمد بن مكرم بن منظور، جــ الص |ل 11 ، ، الطبعة الأولى، دار صادر، بيروت - لبنان. 


\section{Cen}

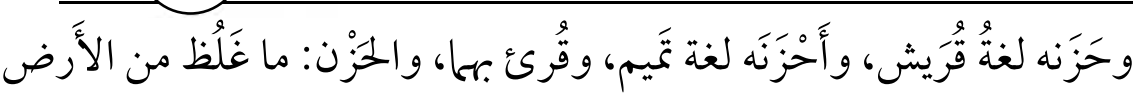

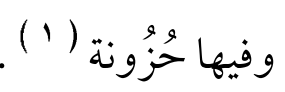

يقول الإمام الراغب (r ) :" الحوزْن والحَزَن : خشونة في الأرض وخشونة في

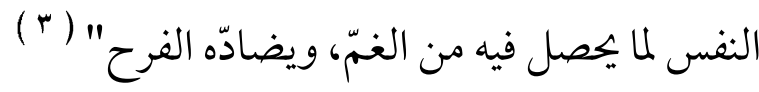

ثانيًا : تعريف الحزن اصطلاحًا . ما

و الحُّزنُ اصطلاحًا: هو عبارة عما يجصل لوقوع مكروه، أو فوات محبوب في

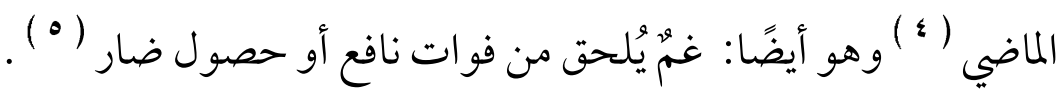

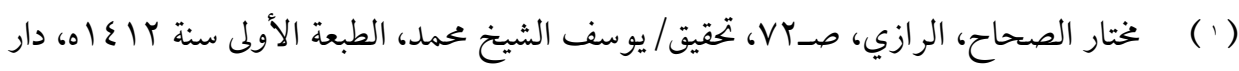

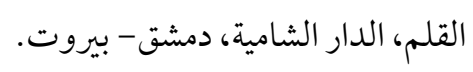

هو الحسين بن محمد بن المفضل، أبو القاسم الأصفهاني المعروف بالراغب أديب من الحكماء

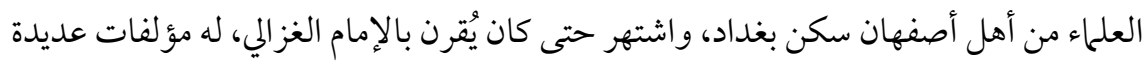

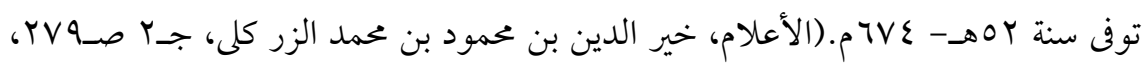

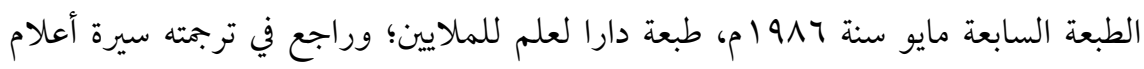

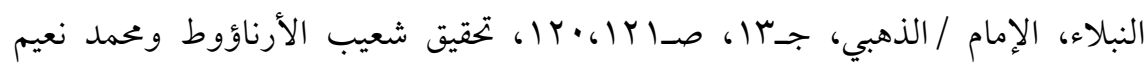
العرقوسى، الطبعة السابعة سنة ، • إ (هـ- • • (199م، مؤسسة الرسالة)

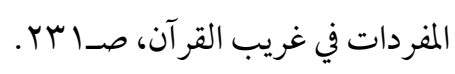

التعريفات، الجرجاني، صـ1،، تحقيق/جماعة من العلماء، الطبعة الأولى سنة بــأهـ-

$$
\text { 1991 19مدار الكتب العلمية، بيروت - لبنان. }
$$

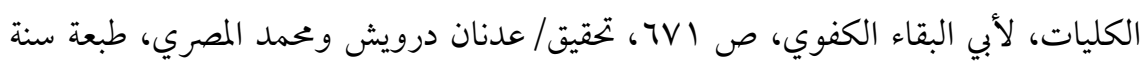

$$
\text { 19 19 إهـ-1991 19، مؤسسة الرسالة. }
$$




\section{C2}

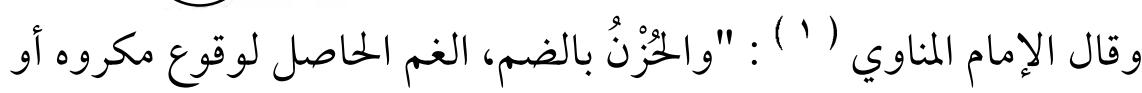

فوات محبوب في الماضي ويضاده الفرح" ( " ).

وقال الإمام ابن القيم ( " ) : " هو انخلاع عن السرور، وملازمة الكآبة

لتأَسف عن فائت أو توجع لممتنع، وهو من منازل العوام لأن فيه نسيان المنة، و البقاءَ في رق الطبع، وهو في مسالك الخو اص حجاب؛ لأن معرفة الله جلا نورها كل ظلمة، وكشف سرورها كل غمة" ( ؛ ) .

عمد عبد الرؤوف بن تاج العارفين بن على بن زين العابدين الحدادي ثم المناوي القاهري، زين

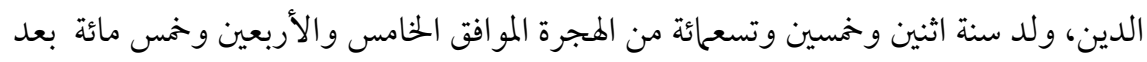

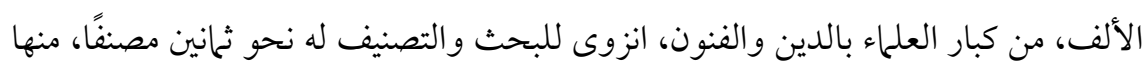
الكبير والصغير والتام والناقص عاش في القاهرة، وتوفى بها سنة إحدى وثلاثين وألف من التين

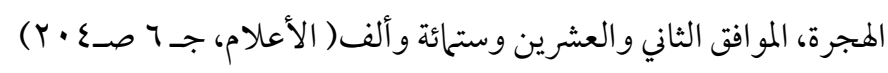

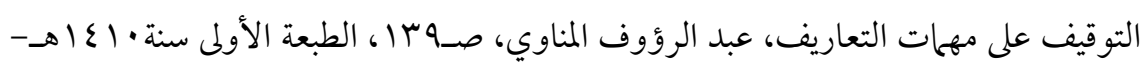

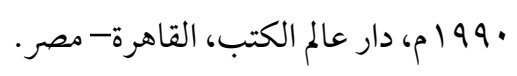

ابن القيم هو: محمد ابن أبى بكر ابن أيوب ابن سعد الزرعى الدمشقي أحد كبار العلماء مولده

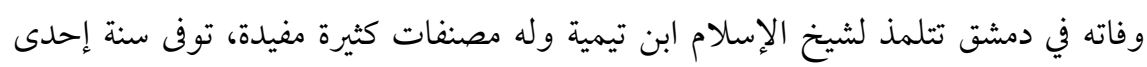

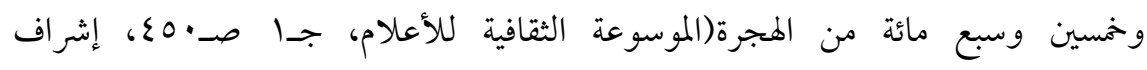
الدكتور / حسين سعيد، طبعة سنة ولن ( م، طبعة دار الشعب).

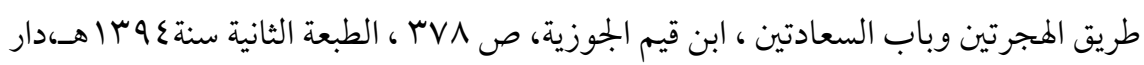
السلفية، القاهرة، مصر 


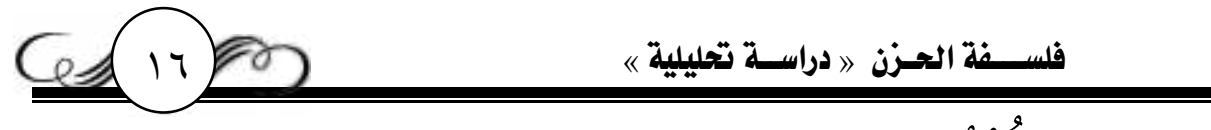 الحُزْنُ في علم النفس.}

هو حالة مؤقته من الغم والهبوط المعنوي ( 1 () وهو أيضًا:انفعال كوني له

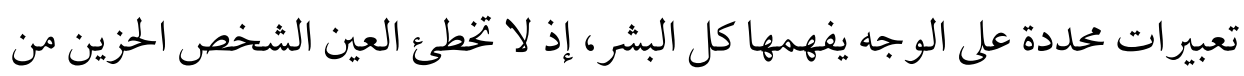
تقطيبه حاجبيه، وضيق عينيه، وربها ارتجاف الذقن بعض الشيء كما تصحب البكاءً غالبًا كل هذه التعبيرات، فالبكاء إثارة واضحة للتعبير عن الحزن وطلب المساعدة

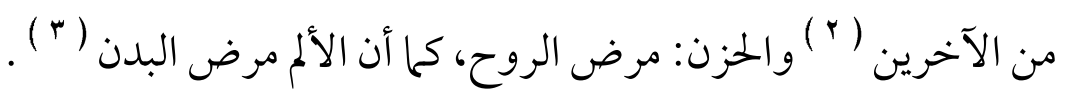

ويمكن أن نقول: إن الحزن عبارة عن حالة انفعالية يصحبها تغير في الحالة

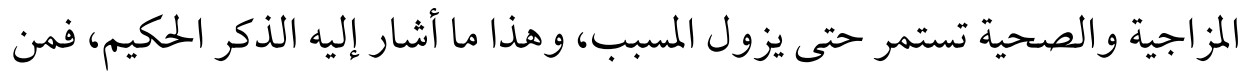

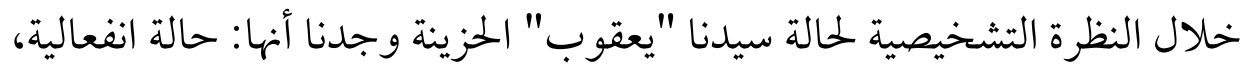

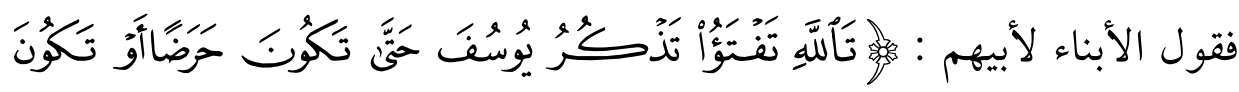

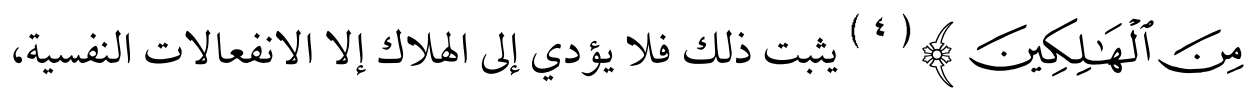

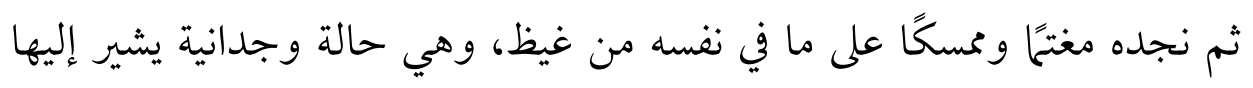

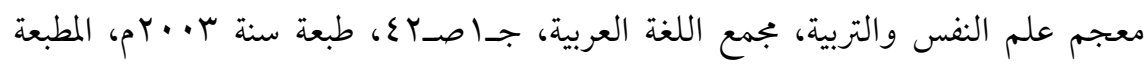

$$
\text { الأمرية ، مصر. }
$$

الحزن الخبيث، لويس ولبرت، صــاع (، ترجمة/ عبلة عودة، مراجعة د/ أمد خريس ، الطبعة

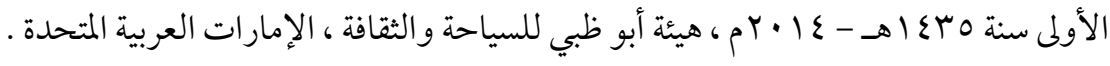

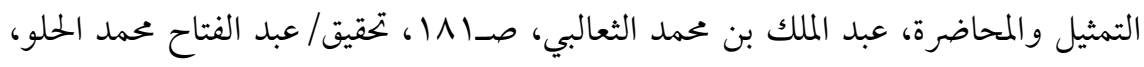

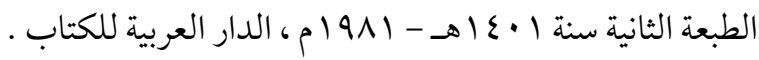

$$
\text { سورة يوسف، الآية:10. (10. }
$$




\section{Gen}

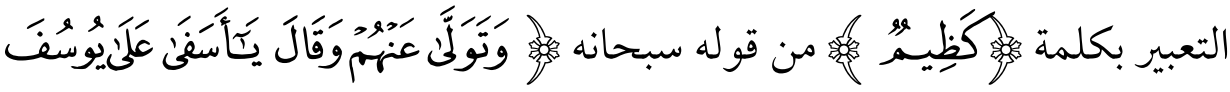

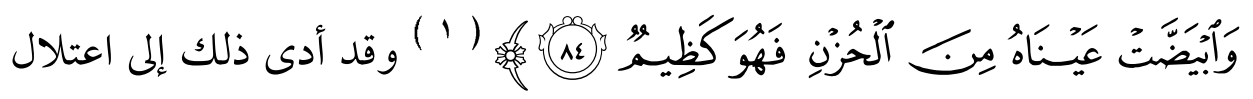

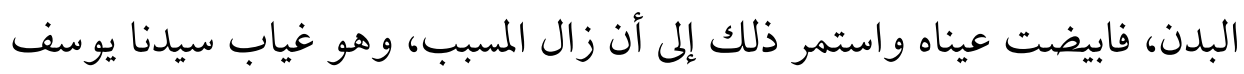

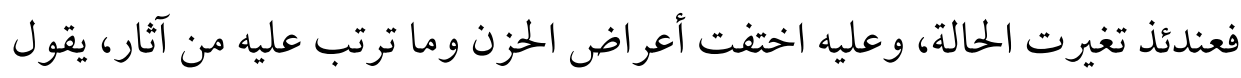

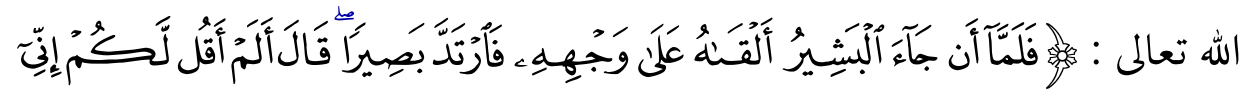

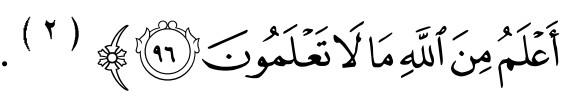
فأمر اض الحزن النفسية والعضوية التي حذر منها الأطباء موجودة في كتاب

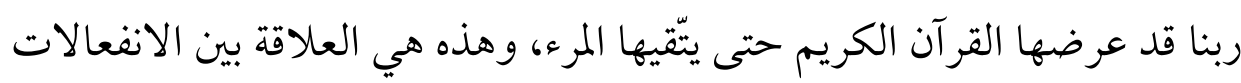
النفسية والأمراض العضوية.

\section{حقيقة الحزن عند الصوفية.}

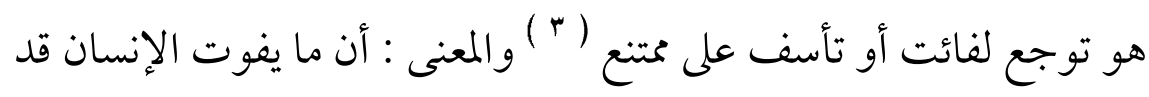

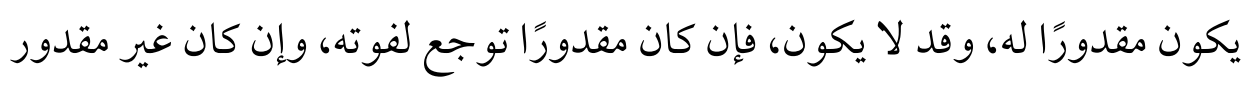

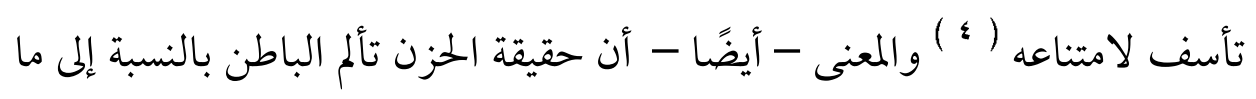

$$
\text { سورة يوسف، الآية:1ع. }
$$

منازل السائرين، عبد الله بن محمد الأنصاري الهروي، صـهب، بالهار الكتب العلمية، بيروت-

لبنان.

مدارج السالكين بين منازل إياك نعبد وإياك نستعين ، ابن قيم الجوزية ، جـ اص ب.0 ،

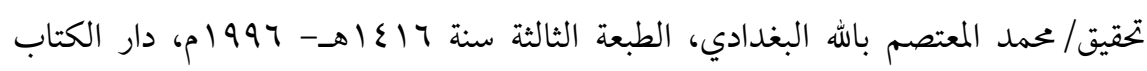

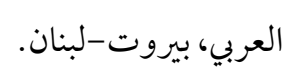




\section{6}

مضى؛ وذلك ' إما لفائت يمكن تداركه - كقضاء الصيام والصلاة - أو فائت يمتنع تداركه - كالتأسف على الميت وإرادة حيوته- و المر اد هـنا الأول ( ' ) . وهو حال يقبض القلب عن التفرق في أودية الغفلة (r ) وهو : انكسار القلب وخشوعه، وعلامته انكسار الجوارح الظاهرة من الانبساط، لانكسار

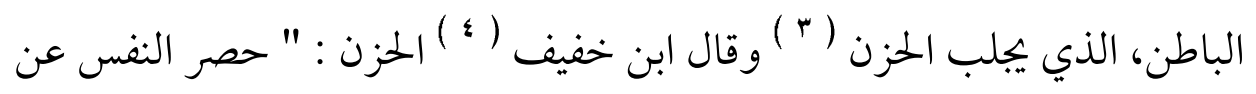

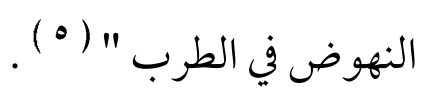
وحقيقته عندهم أنه: قبض بطرق القلب يمنعه من الانبساط ، وقد يكون

شرح منازل السائرين، كال الدين عبد الرازق القاساني، صــــا، تحقيق/ عسن بيداء فر،

$$
\text { مؤسسة التاريخ العبي، ودار حواء. }
$$

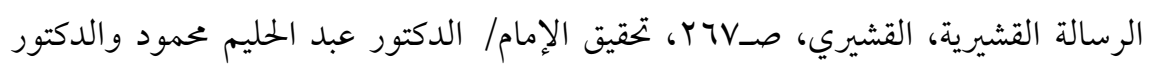

$$
\text { محمود بن الشريف، دار المعارف، القاهرة. }
$$

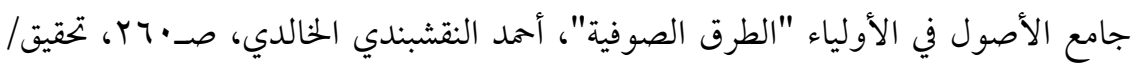

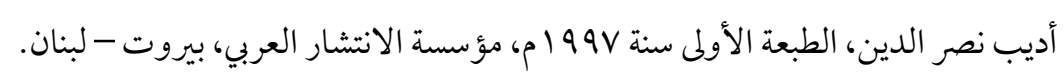

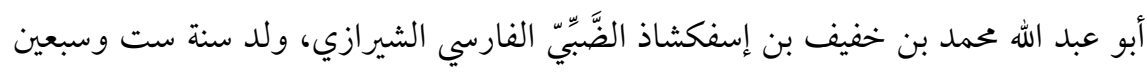

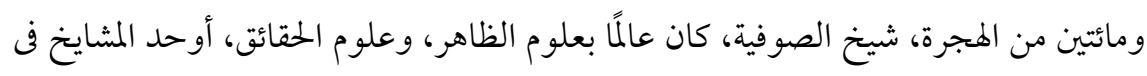

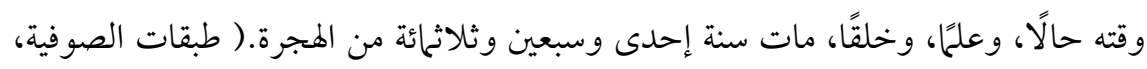

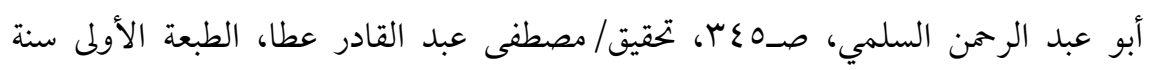

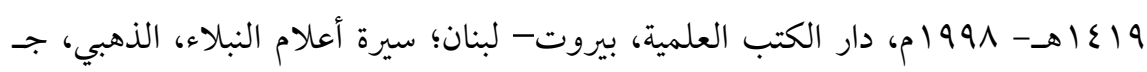

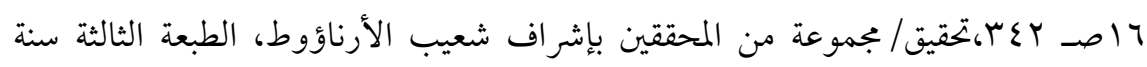

$$
\begin{aligned}
& \text { هـ ـ ( هـ - } 1910 \text { 1م، مؤسسة الرسالة، بيروت - لبنان) } \\
& \text { الر الة القشيرية، صـح؟r. }
\end{aligned}
$$




\section{6.}

معه ألم وقد يكون غمى، ولذا يمنع من الشعور بالألم، ويكون سببه نظرًا في أمر ماض، أو استشعار فوات محبوب حاصل أو مككن الحصول، أو نزول مكروه مؤلم في

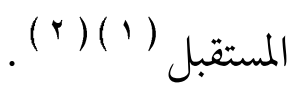
وهو أيضًا عندهم: انكسار الفؤاد لفوات المراد، وقيل: زوال قوة القلب

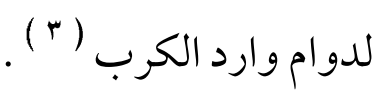

\section{تعريف الفلاسفة للحزن.}

هو ألم نفساني يعرض لفقد المحبوبات، وفوت المطلوبات ( ؛ ) وهنا يلفت الكندي الأنظار إلى أن المرغوبات والمحبوبات من الأشياء المادية الحسية في عالم الشهادة، سبب لشعور الإنسان بالحزن والألم؛ لكونها عرضة للاضمحلال والزوال، فيحزن المرء لفسادها وضياعها، أما الثابت الذي لا يطرأ عليه الفساد والتغير، فالمحبوبات و المطلوبات العقلية، فغالبًا ما تكون دائمة وثابته، وعليه فمن أراد الراحة والسعادة، وتوقي الحزن والألم، فليجعل مرغوباته ومطلوباته المحببة في

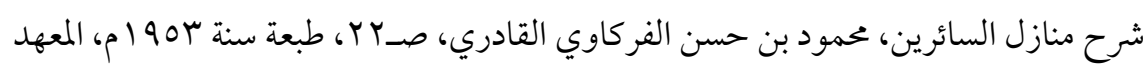
العالي الفرنسي للآثار الشرقية بالقاهرة.

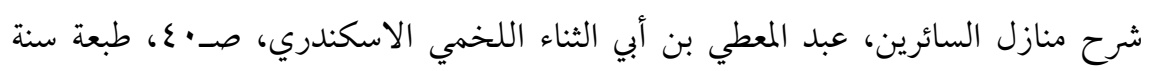
ع 90 1م، المعهد العالي الفرنسي للآثار الشرقية بالقاهرة.

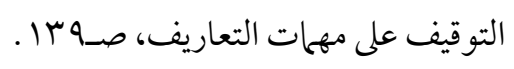

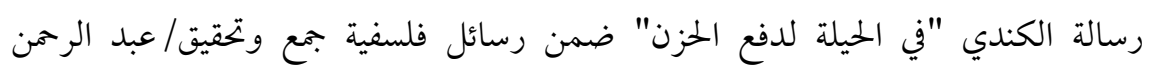

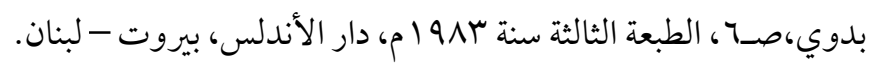




\section{Ges.}

العالم العقلي لا العالم الحسي . - الح

يقول الكندي ( ' ) : " فإنه ليس بممكن أنين الأحد جميع محبوباته ؛ لأن

الثبات والدوام معدمان في عالم الكون و الفساد - الحياة الدنيا -الّذي نحن فيه وإنما الثبات والدوام موجودان اضطرارًا في عالم العقل - ما بعد الموت - الذي هو مككن لنا مشاهدته فإن أحببنا أن لا نفقد محبوباتنا ولا تفوتنا طلباتنا فينبغي أن نشاهد

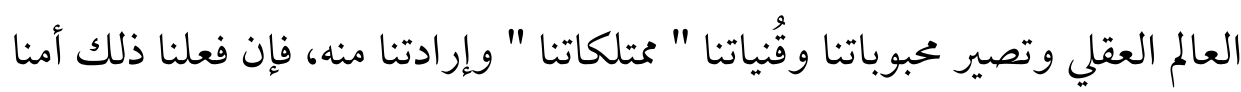
أن يغصبنا قنياتنا أحد أو تملكها علينا يد وأن نعدم ما أحببنا منها إذ لا تناها الآفات و لا يلحقها الممات ولا تفوتنا الطِلبة ، اذا لمطالب العقلية و اقفة غير متحركة ولازائلة ، فهي مدركة غير فائتة ، فأما القنية الحسية والمحبوبات الحسية والطلبات الحسية فإنها موقوفات لكل أحد ومنال لكل يد لا يمكن تحصينها ولا يؤمن فسادها

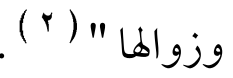

وإذا كان الأمر كذلك، فلا ينغي للإنسان أن يحزن؛ لأن لو حزن لكل مطلوب يقصده، ولكل مرغوب يفوته، لكان دائم الأحزان، وهذا ما أشار إليه

الكندي: أبو يوسف يعقوب بن إسحق الكندي، ولدي بالكوفة في مطلع القرن الثامن الميلادي،

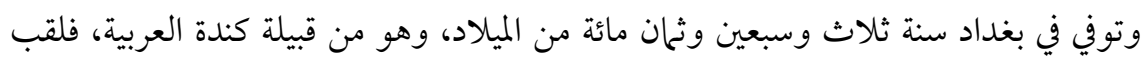

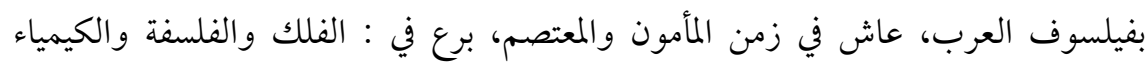
والفيزياء والطب والرياضة والموسيقة وعلم النفس، وقد شغل بترجمة كتب اليونان(معجم

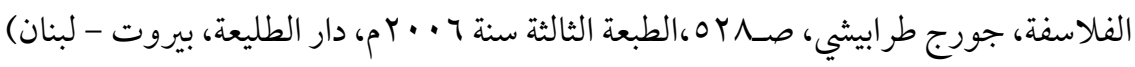

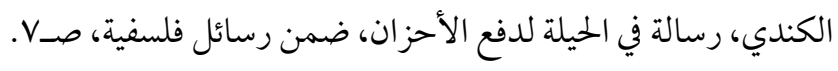




\section{Ge}

الكندي بقوله:" فينبغي إذن أن لا نحزن على الفائتات، ولا فقد المحبوبات، وأن نجعل أنفسنا بالعادة الجمميلة، راضية بكل حال؛ لنكون مسرورين أبدًا" ( ' ). ويقول مسكوية (r ) : " تعجل ألم ومكروه على ما لا يجدي الحزن إليه

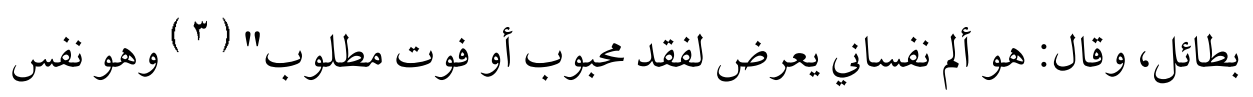
تعريف الكندي.

و الحزن عند الفلاسفة هو: ألم نفساني يغمر النفس كلها وير ادفه: الهم، والغم، والكآبة ( ؛ ) وليس هذا فحسب، بل يرادفه أيضًا: الأسف، الأسى، الابتئاس، الكرب ، الكمد، البث، وبين هذه المترادفات فروق لغوية نوضحها فيما يلي:

$$
\text { المرجع السابق، ص } 9 .
$$

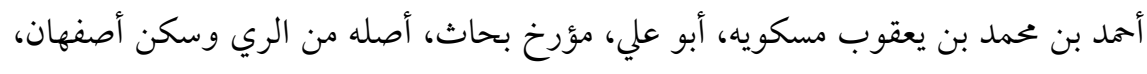

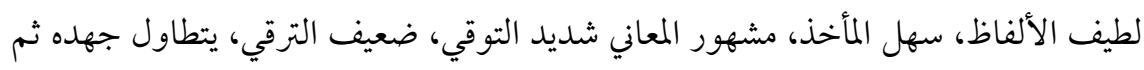

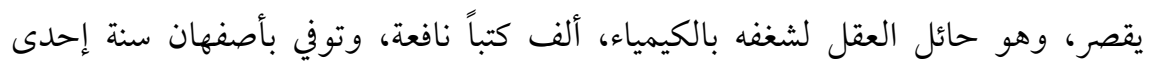

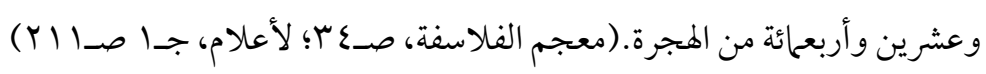

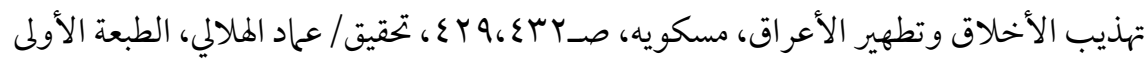

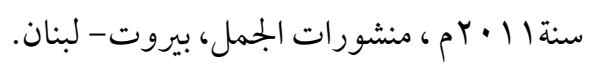

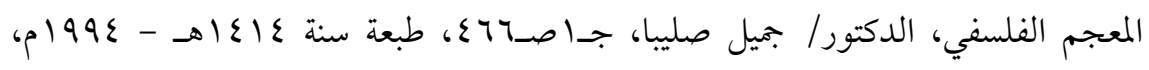

$$
\text { الشركة العالمية للكتاب، بيروت- لبنان. }
$$




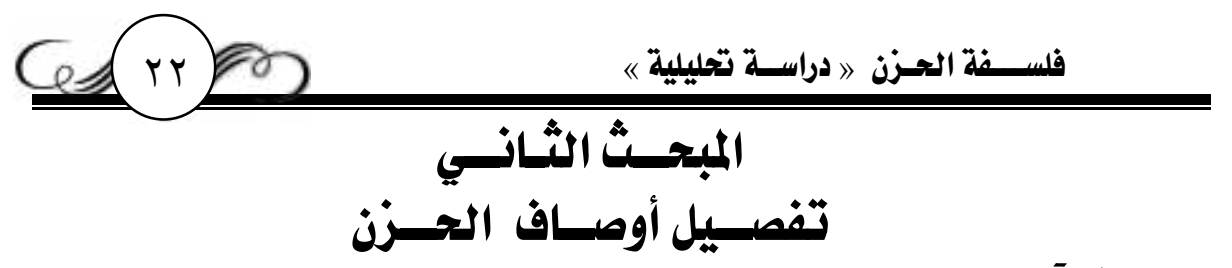

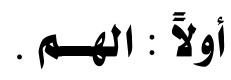

إن المكروه الذي يرد على القلب إن كان لما يستقبل أورثه الهم، وإن كان لما مضى أورثه الحزن ( ' ) فالحزن على الماضي، والهم للمستقبل. وقيل: الفرق في الشدة والضعف، فإن الهم من حيث إن تركيبه أصل في الذوبان، يقال: أهمني المرض بمعنى أذابني، وسنام مهموم مذاب، وسمي به ما

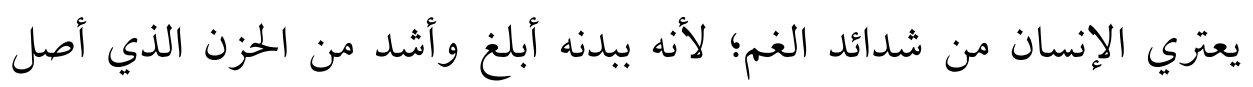

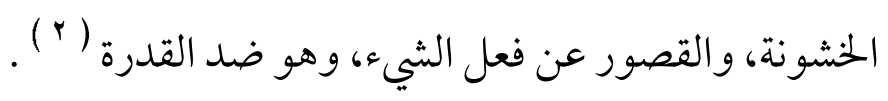
يقول صاحب الفروق اللغوية: "الهم هو الفكر في إزالة المكروه واجتلاب المحبوب....وقد سمي الحزن الذي تطول مدته حتى يذيب البدن همًا واشتقاقه من

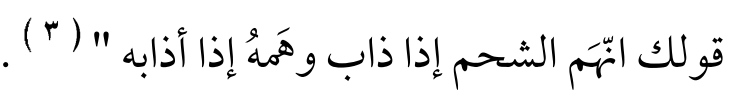

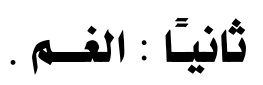

لقد جاء الغم في سبعة مواضع من القرآن الكريم على صيغة المصدر فقط،

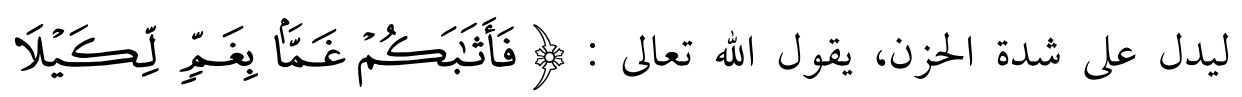

$$
\text { مدارج السالكين بين منازل إياك نعبد وإياك نستعين، صـا م } 0 .
$$

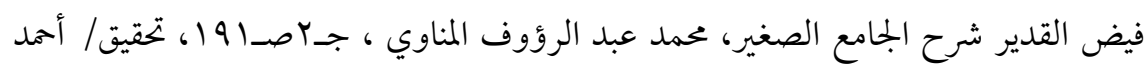

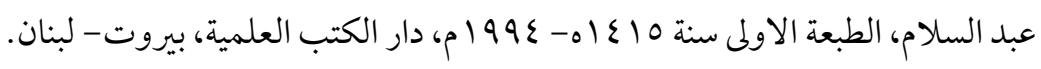

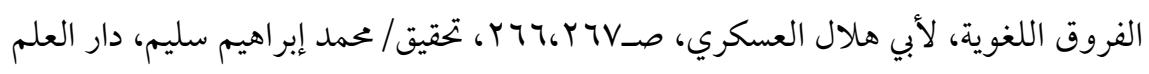

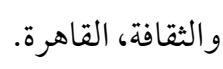




\section{Ges re}

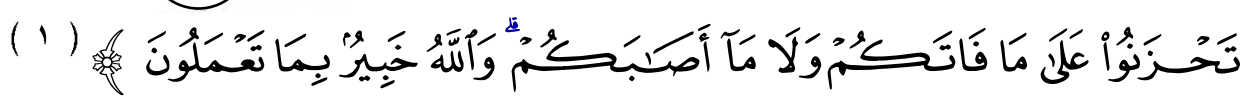

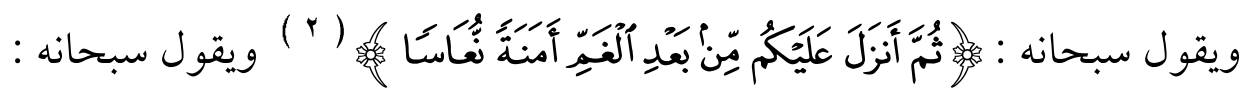

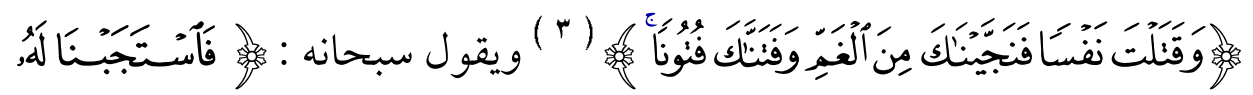

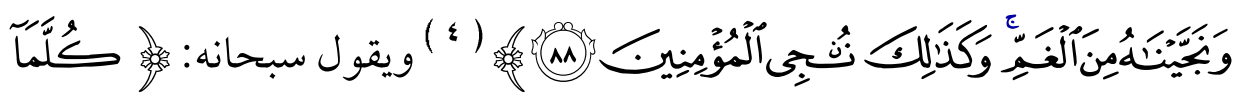

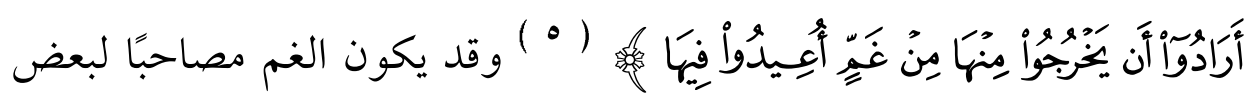

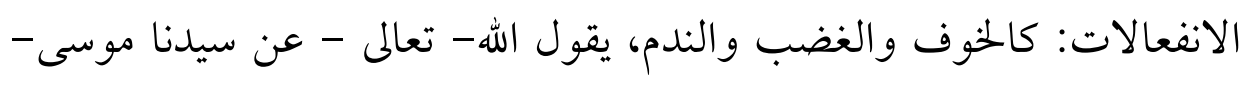

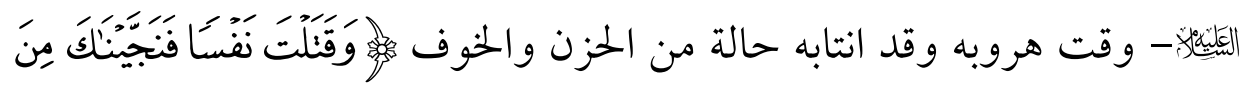

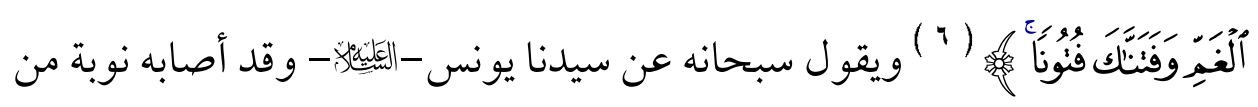

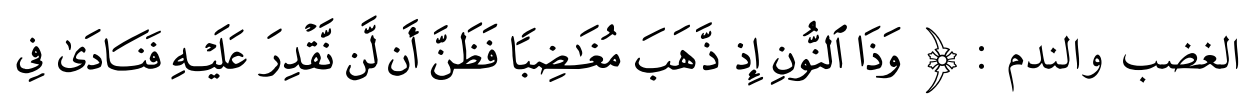

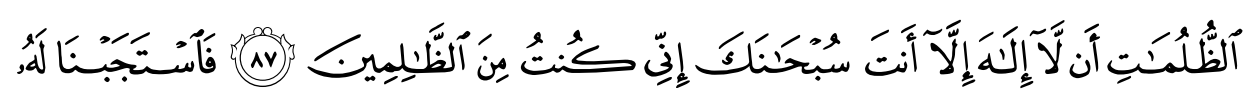

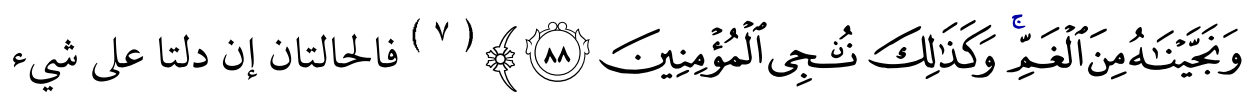
فإنما تدلان على حزن شديد مطبق، لم يستطيعا التخلص منه، والسيطرة عليه.

$$
\begin{aligned}
& \text { سورة آل عمران، الآية:سه } \\
& \text { سورة آل عمران، الآية:؛ } 10 . \\
& \text { سور طه، الآية:•ع. } \\
& \text { سورة الأنبياء، الآية: 1^. } \\
& \text { سورة الحج، الآية:بr. } \\
& \text { سور طه، الآية:••ع. }
\end{aligned}
$$

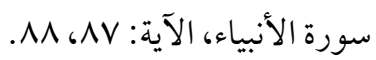




\section{Ges.}

يمكن أن نقول: إن الغم انفعال نفسي يدل على الحزن الشديد المكبوت المصاحب للخوف والندم، مع وجود حالة من الغضب في بعض الأحيان. ويقول الإمام محمد عبده ( 1 ) : " الغم هو الألم الذي يفاجئ الإنسان عند نزول المصيبة، وأما الحزن فهو الألم الذي يكون بعد ذلك ويستمر زمنًا " ( ( ). و الغم قد لا يعرف سببه، ولا تتبين حقيقته بخلاف الحزن، وهذا ما يدل عليه مادته، فإنها تدل على الخفاء والستر، تقول: غَمَّ الشيء إذا أخفاه، وغمي على المريض إذا غشي عليه كأنه سـتر عقله، وغم عليهـمم الهـلال لم يره أحسـ، ومنه قوله تعالى :

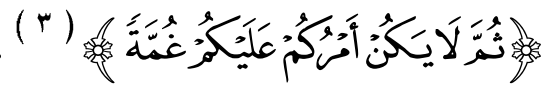

وقيل: الغم أخص من الحزن وهو شامل لجميع أنواع المكروهات، والغم

الإمام محمد عبده: ولد في قرية محلة نصر بالبحيرة عام خمسة وأربعين وثمانمائة وألف من الميلاد، التحق بالجامع الأحمدي، ثم أرسله أبوه إلى الجامع الأزهر إلى أن جاء السيد جمال الدين الأفغاني فأخذ عنه الإمام الكثير حتى أصبح ذا مكانة بارزة، تولى بعض المناصب منها: رئيس تحرير الوقائع المصرية، ثم مديراً للمطبوعات المصرية حتى نفى إلى الشام، ثم عاد فعين مفتياً للديار

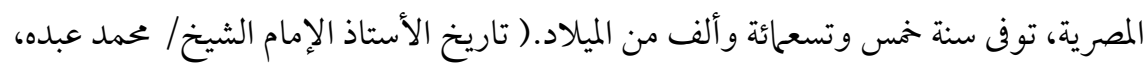
جـr صـ9 1، السيد محمد رشيد رضا، طبعة سنة ع بr اهـ، مطبعة المنار؛ وكذلك كتاب أعلام الفكر الإسلامي، الدكتور/ عثمان أمين، صـع؛، طبعة ستة ا99 ام ، دار الثقافة للنشر والتوزيع) تفسير المنار، العلامة/ محمد رشيد رضا، جــصـا 0 10، طبعة سنة •99 (م، الميئة المصرية العامة للكتاب.

$$
\text { سورة يونس، الآية:VI. }
$$




\section{6}

بحسب ما يصده، والحزن ما يلحقه بسبب حصول مكروه في الماضي، والغم على

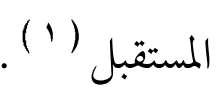

وهذه الحالة من الحزن الشديد يمكن علاجها بالخلود إلى النوم كما أرشد

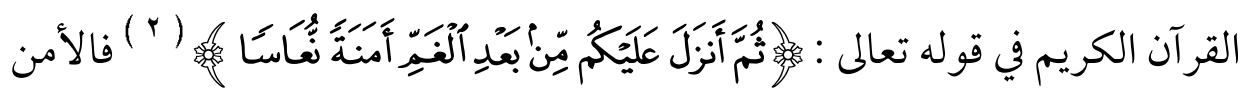
يكون مع زوال سبب الغم وهو الخوف، ولقد أمنهم الله يومئذ بنعاس يغشاهم.

\section{ثالثًاً : الكآبــة.}

هي سوء الهيئة والانكسار من الحزن في الوجه خاصة ( "َ ) فهي أثر للحزن

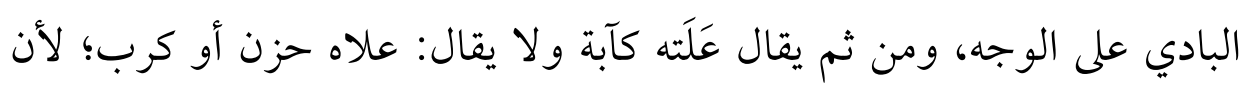
الحزن لا يرى ولكن دلالته على الوجه، وتلك الدلالات تسمى كآبة، والشاهد قول

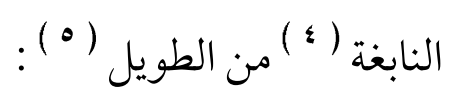

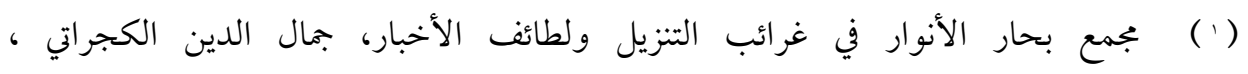

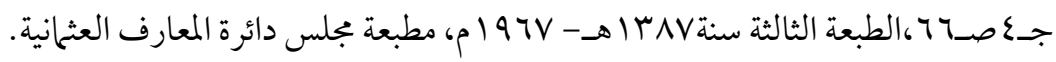

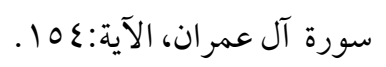

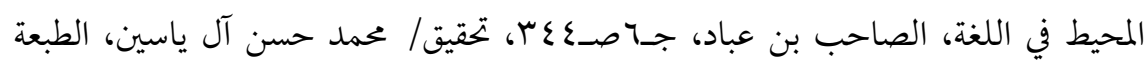

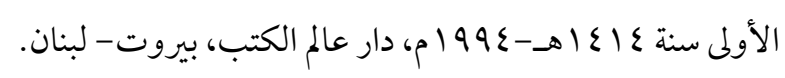

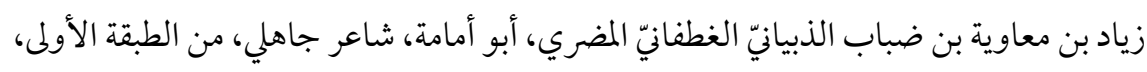

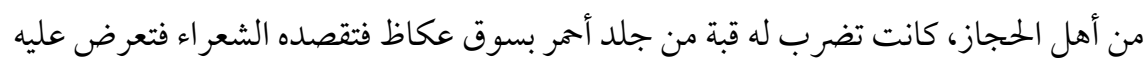

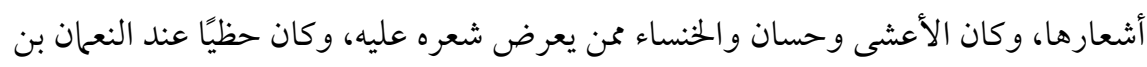

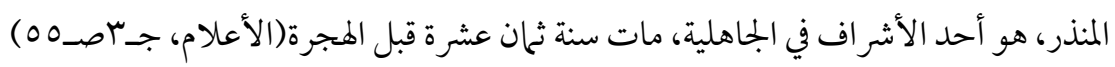

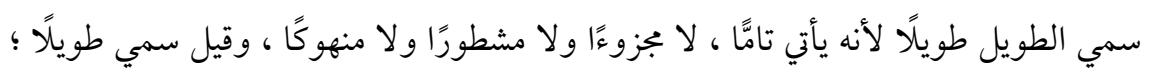
$=$ 


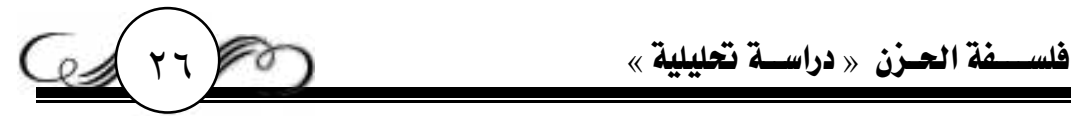

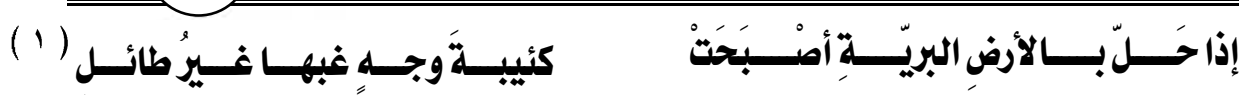 \\ الشاهد أنه جعل الكآبة هنا في الوجه (r (r) ). \\ رابعتًا : الأســف أنهـ}

وردة مادة أسف وما يشتق منها في خمسة مو اضع من القر آن الكريم، أسندت

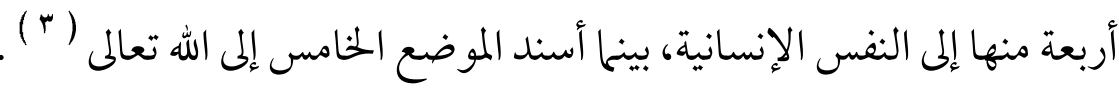

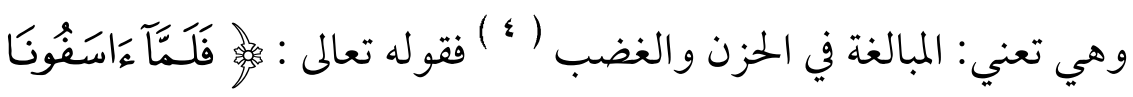

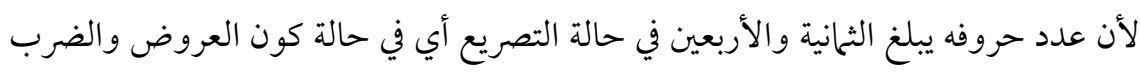

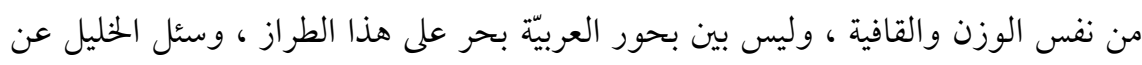

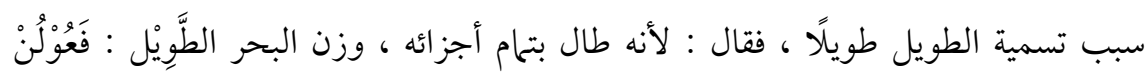

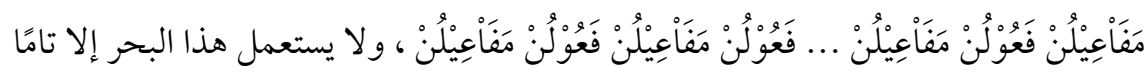
وجوبًا (العروض الواضح وعلم القافية، الدكتور / عمد علي الهاشمي، صـه r، الطبعة الأولى

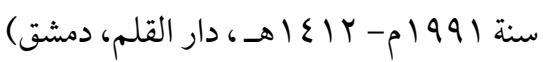

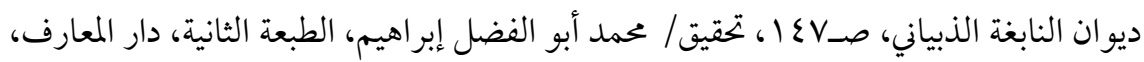
مصر

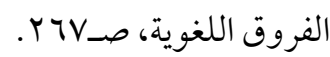

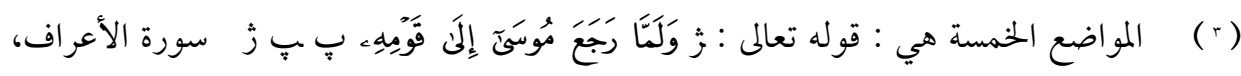

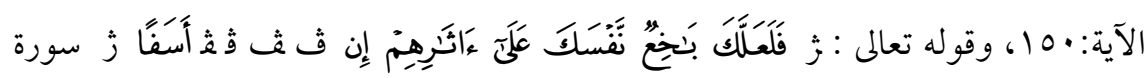

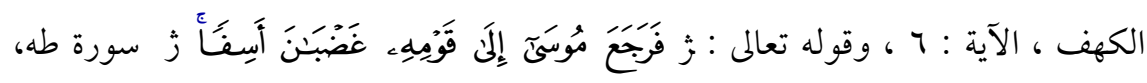

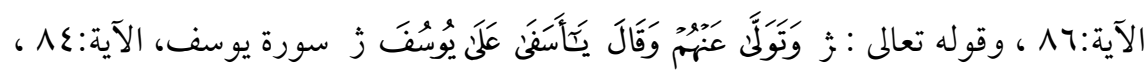

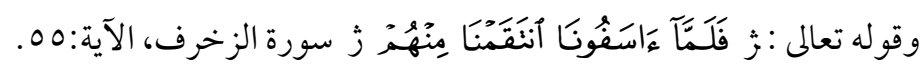

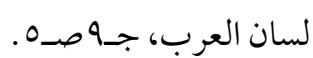




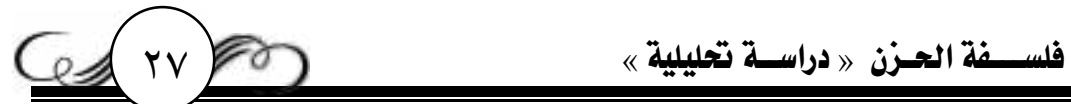

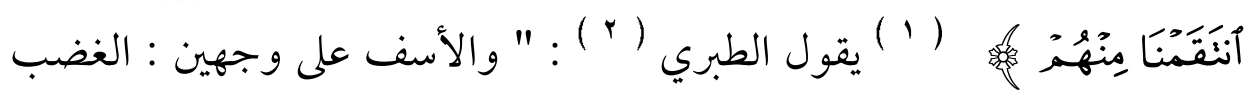

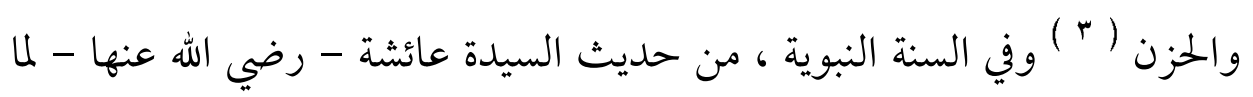

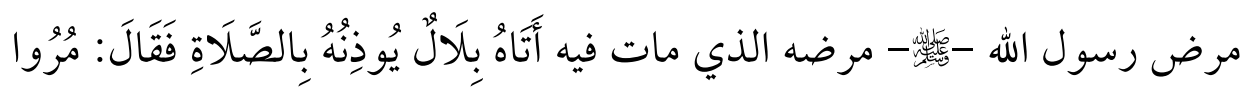

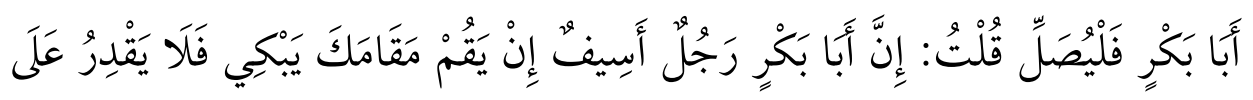

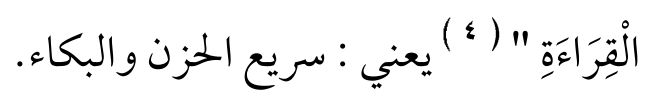

وفي حديث "موت الفجأة " الذي رواه الإمام أحمد ( • ) في مسنده من لئن

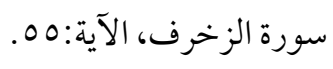

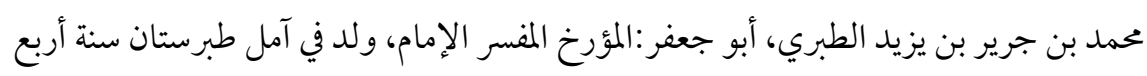

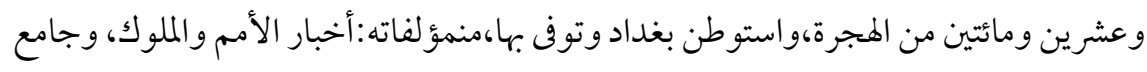

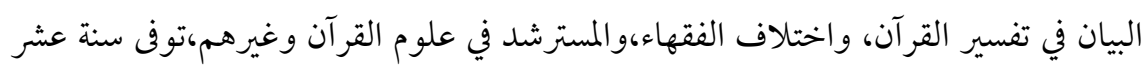

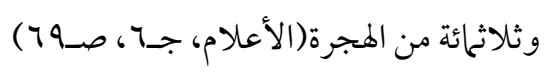

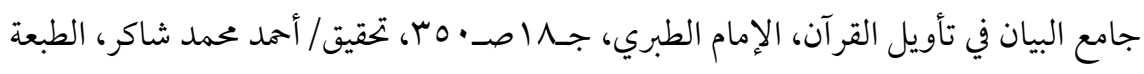

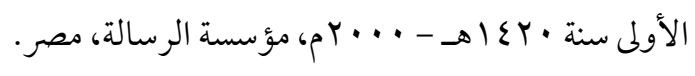

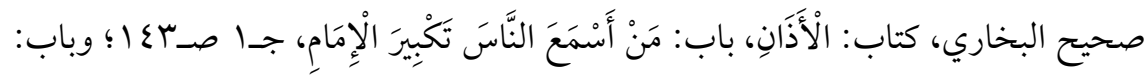

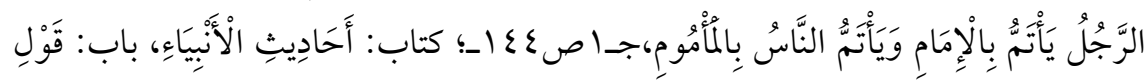

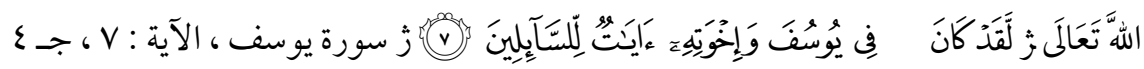

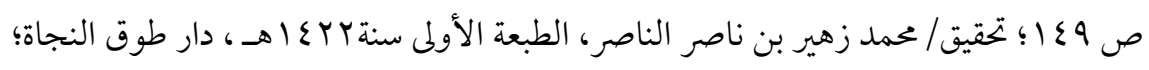

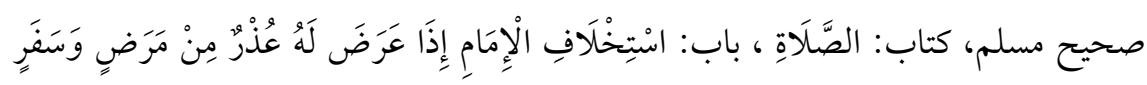

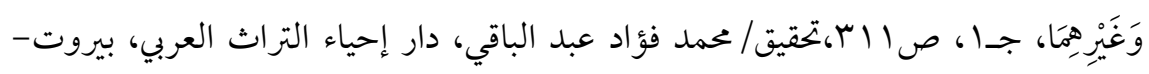

لبنان.

هو أمد بن حنبل ينتهي نسبه إلى إسماعيل بن إبراهيم الخليل - عليهها السلام - أبو عبد الله $=$ 


\section{Con}

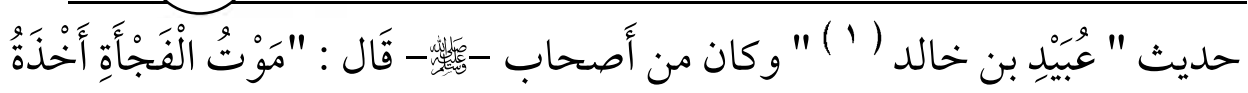

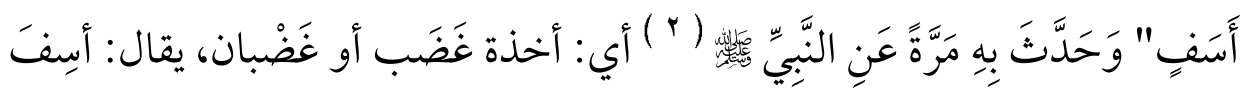

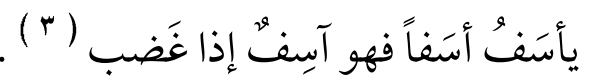
فالأسف: الحزن والغضب معًا، وقد يقال: لكل واحد منها على الانفراد، وحقيقته: ثوران دم القلب شهوة الانتقام فمتى كان ذلك على من دونه انتشر فصار

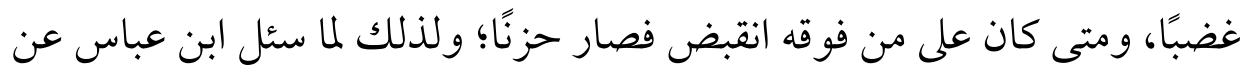
الحزن والغضب قال:""خرجها واحد، واللفظ خختلف، فمن نازع من يقوى عليه

الشيباني المروزي ثم البغدادي قدم به أبوه من مرو مدينة بخرسان وهو حمل فوضعته أمه ببغداد

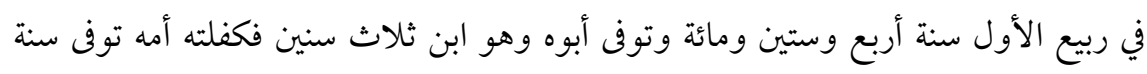
إحدى وأربعين ومائتين وله من العمر سبع وسبعون سنة رحمة الله ( البداية والنهاية ، ابن كثير،

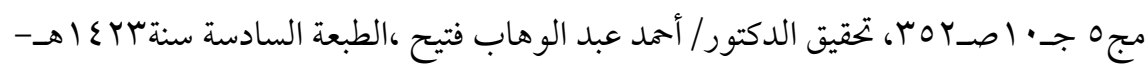

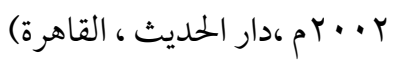

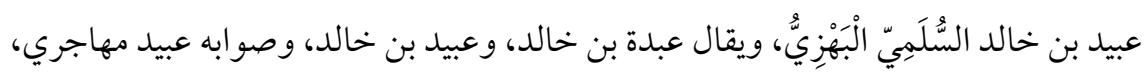
( )

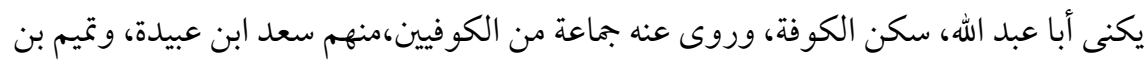
سلمة، شهد صفين مع علي رضي الله عنه. (الاستيعاب في معرفة الأصحاب، ابن عبد

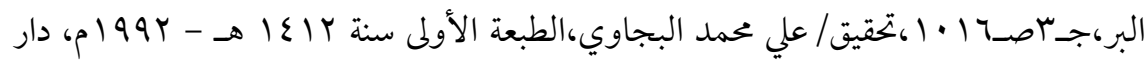

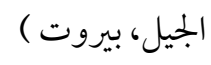

إسناده صحيح ورجاله ثقات رجال الشيخين، المسند، جــrصدهب، تحقيق/ شعيب

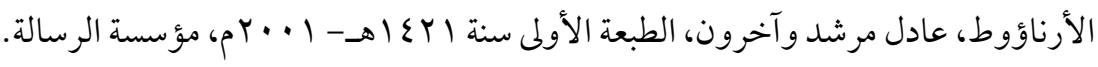

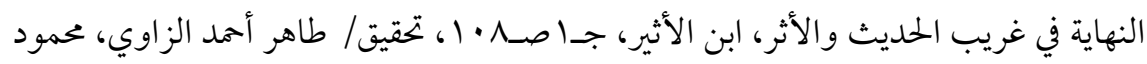
محمد الطناحي، طبعة سنة 99 با هـ- 9 ( 9 م، المكتبة العلمية، بيروت- لبنان. 
أظهره غيظًا وغضبًا، ومن نازع من لا يقوى عليه، أظهره حزنًا وجزعًا" ( 1 ( )

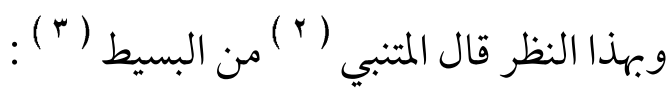

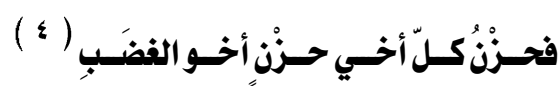

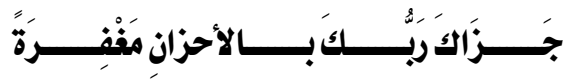
فالأسف حالة تعكس مشاعر الحزن الشديد البالغ منزلة وراء الغضب وأشد منه، يقول الله -تعالى - عن سيدن موسى - الئليَّلمّ - حين انتابته حالة من الحزن

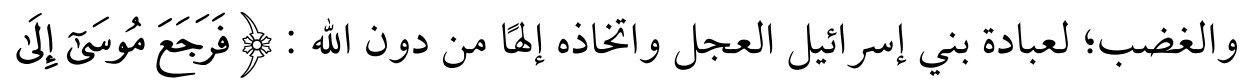

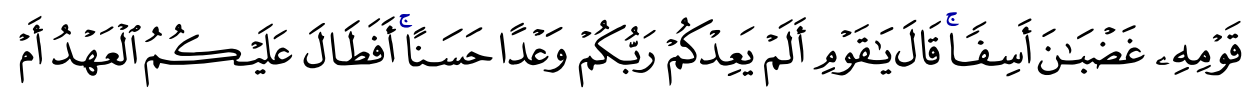

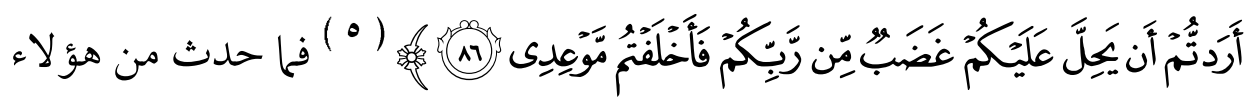

$$
\text { المفردات في غريب القرآن، صـه. }
$$

أبو الطيب أحمد بن الحسين الجعفي، الشاعر المعروف بالمتنبي، ولد بالكوفة، سنة ثلاث وثلاثمائة من الهجرة ، ونشأ بالشام، وأقام بالبادية، وطلب الأدب وعلم العربية، ونظر في أيام الناس،

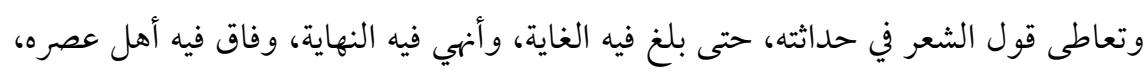

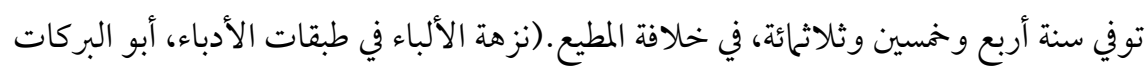

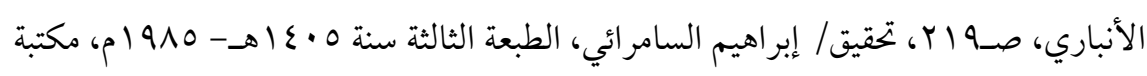

$$
\text { المنار، الزرقاء - الأردن) }
$$

سمي الْبَسِيْط بهذا الاسم: لانبساط أسبابه ، أي تو اليها في مستهل تفعيلاته السباعية، وقيل:

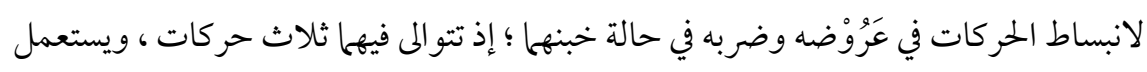

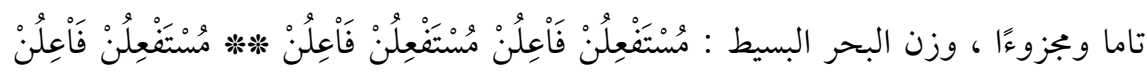

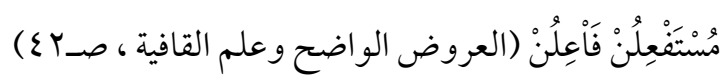

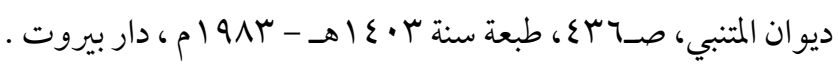

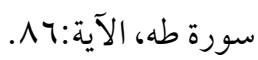




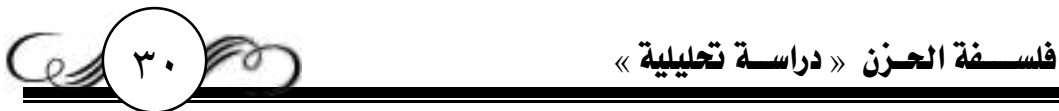

لا يستدعي الحزن الشديد فحسب، بل والغضب أيضًا وهما في الحقيقة متقاربان؛ لأن الغضب من الحزن والحزن من الغضب، فإذا جاءك ما تكره كمن هو دونك غضبت، وإذا جاءك معن هو أعلى حزنت، فتسمي إحدى هاتين الحالتين حزنًا والأخرى غضبًا، فعلى هذا كان موسى -اليَلِّهُة -غضبان على قومه لأجل عبادتهم

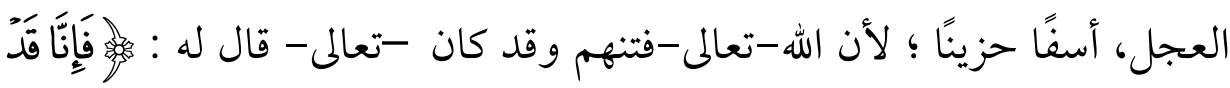

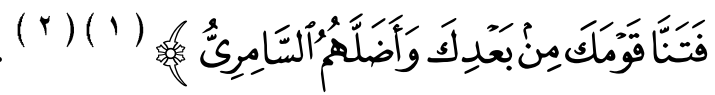 خامسيًَا : الأسبـى .}

جاءت مادة " أسى" وما يشتق منها في أربعة مواضع من القرآن الكريم وكلها على صيغة المضارع المنفي إلا واحدة هي التي سبقت باستفهام. والأسى : هو الحزن الشديد على شيء لم يتحقق ، يقال : أسيت على الشيء آسي أي : حزنت عليه ، وقد أسيت لفلان أي : حزنت له ، قال العجّاج (r ) من

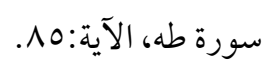

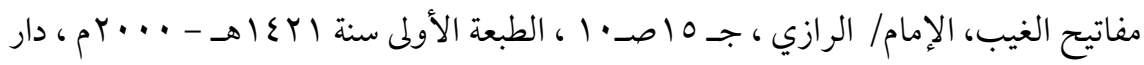

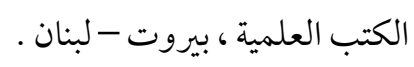

رؤبة بن عبد الله العجاج بن رؤبة التميمي السعدي، أبو الجحّاف أَو أَبو محمد، راجز، من بئن

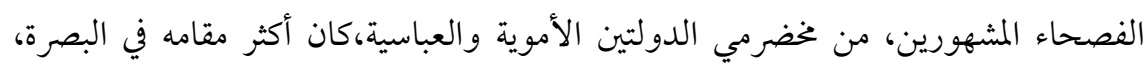
وأخذ عنه أعيان أهل اللغة وكانوا يحتجون بشعره ويقولون بإمامته في اللغة،مات في البادية وقد أسنّ سنة خمس وأربعين ومائة،ولما مات رؤبة قال الخليل:دفنا الشعر واللغة والفصاحة. (وفيات

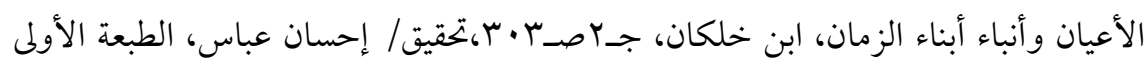

$$
\text { سنة · م9 (1م، دار صادر، بيروت - لبنان) }
$$


Gen

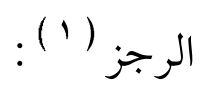

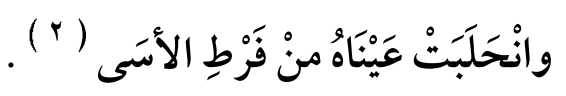

وحقيقته: إتباع الفائت بالغم (" ) وهذه الحالة الانفعالية لها عوامل داخليه،

وعوامل خارجية كحزن وأسى الأنبياء على أقوامهم كما في قول الله - تعالى - غخاطبًا

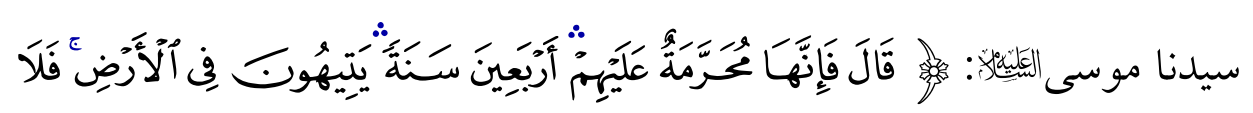

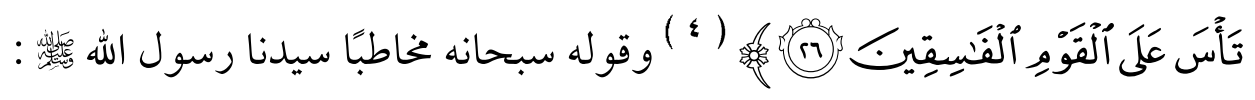

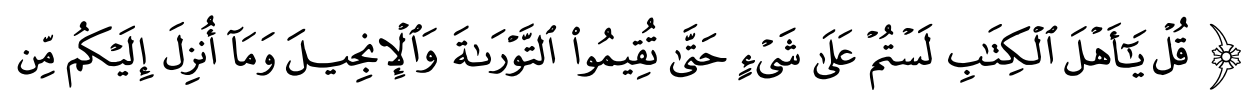

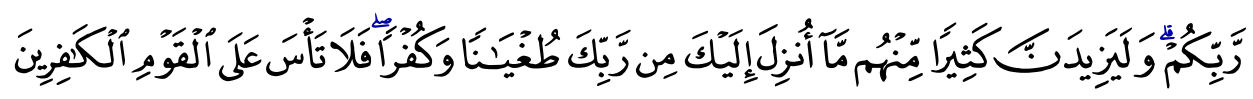

اختلف في سبب تسمية هذا البحر بهذا الاسم ، فقيل : لاضطرابه وهو مأخوذ من الناقة التي يرتعش فخذاها ، وسبب اضطرابه جواز حذف حرفين من كل تفعيلة من تفعيلاته، وكثرة

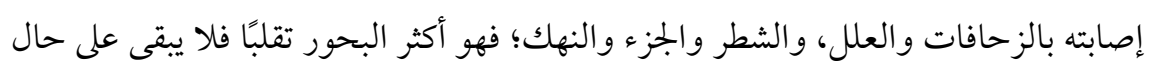

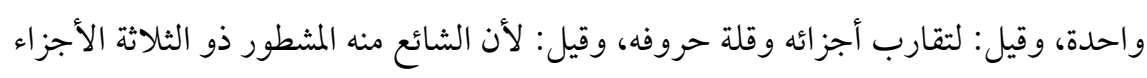
فهو بهذا شبيه بالر اجز من الإبل وهو ما شد إحدى يديه وبقي قائما على ثلاثة قوائم، وزن البحر

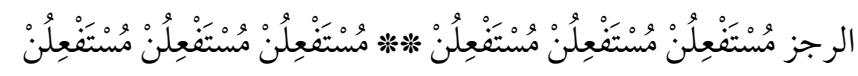

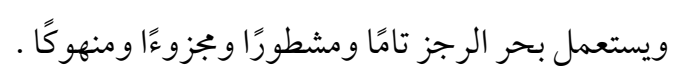

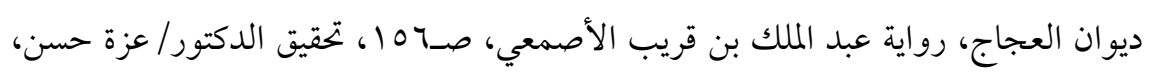

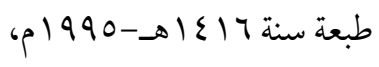

$$
\begin{aligned}
& \text { المفردات في غريب القر آن، صـVV. } \\
& \text { سورة المائدة، الآية:بr. }
\end{aligned}
$$


( غير محله، فهم ليسوا أهلاً للاهتمام؟لكفرهم واستحقاقهم ما نزل بهم، يقول الله

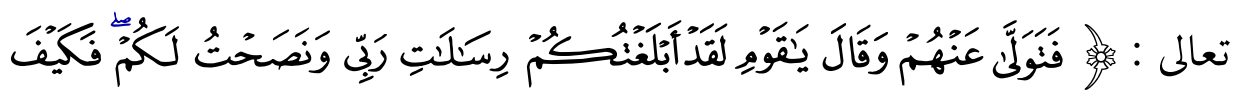

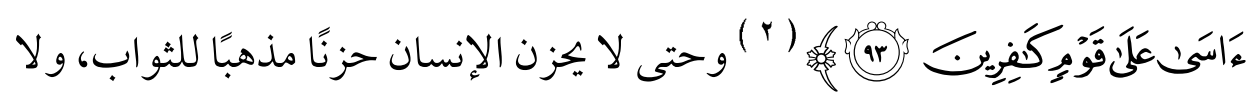

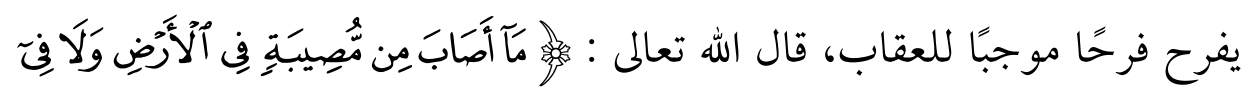

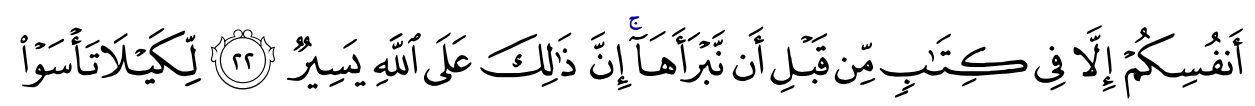

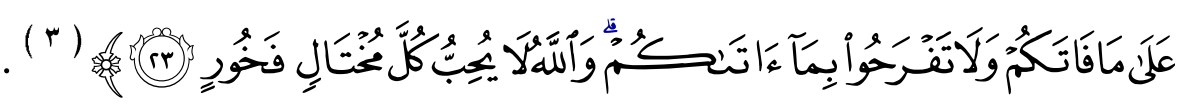
سـادساً: : الابتئساس .

افتعال من البؤس وهو الحزن، يقال: ابتأس الرجل: إذا بلغه شيء يكرهه

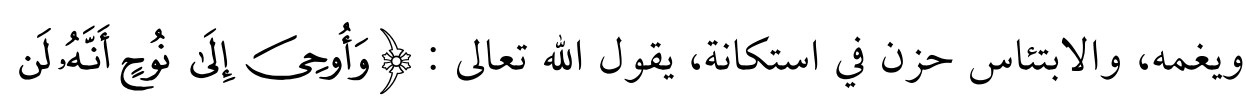

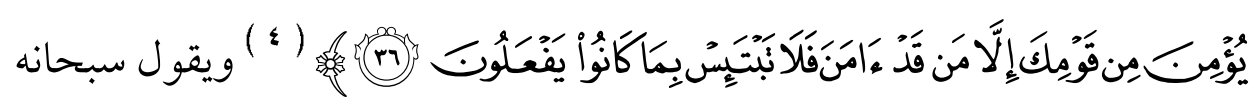
:

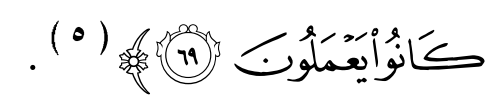

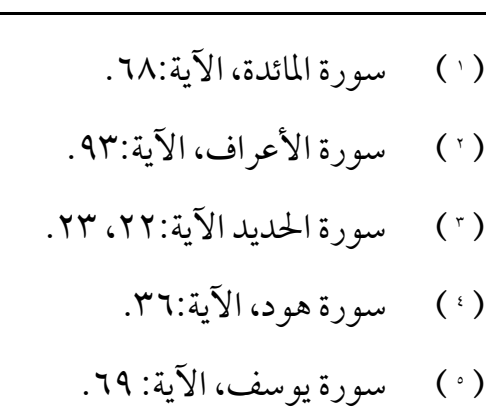




\section{Gen}

يقول الإمام النسفي:" فلا تحزن حزن بائس مستكين، والابتئاس: افتعال من

$$
\text { البؤس وهو الحزن و الفقر " ( ' ) ويقول حسان بن ثابت ( ' ) من البسيط: }
$$

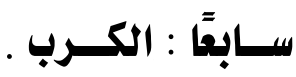

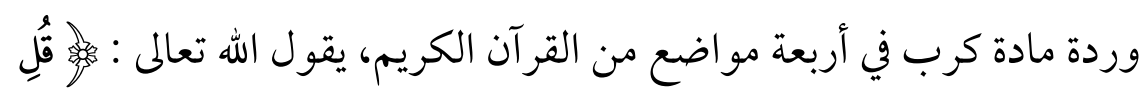

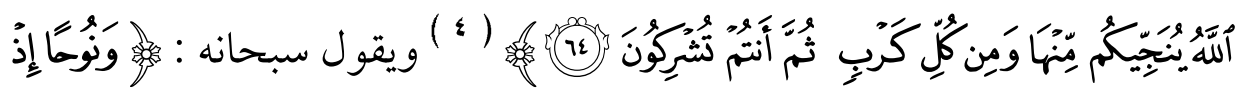

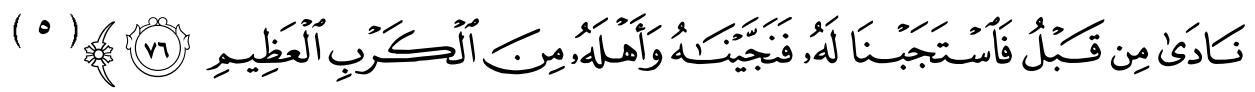

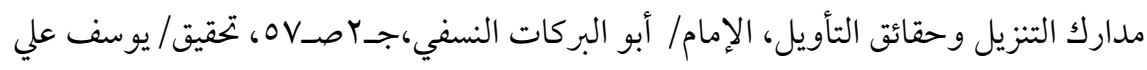

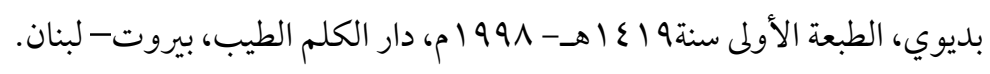

حسان بن ثابت بن المنذر بن حرام بن عمرو بن زيد بن عدى بن عمرو بن مالك بن النجار،

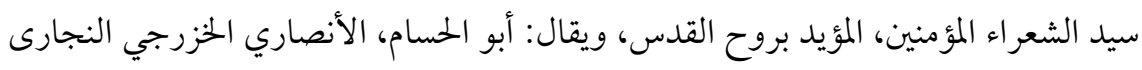

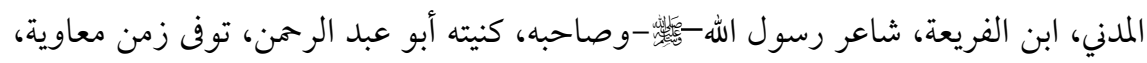

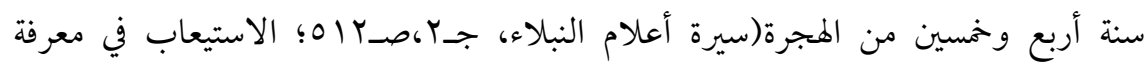

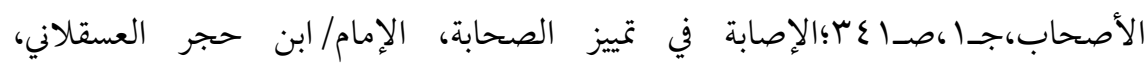

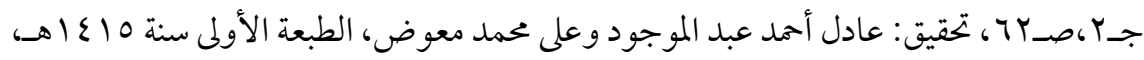

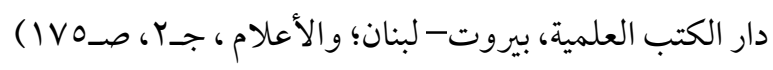

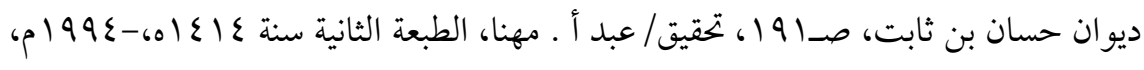

$$
\begin{aligned}
& \text { دار الكتب العلمية، بيروت - لبنان. } \\
& \text { سورة الأنعام، الآية: ؟7. } \\
& \text { سورة الأنبياء، الآية: TV. }
\end{aligned}
$$




\section{6}

ويقول سبحانه

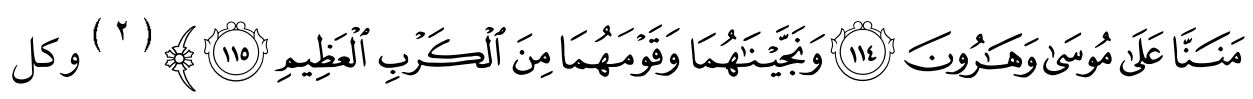

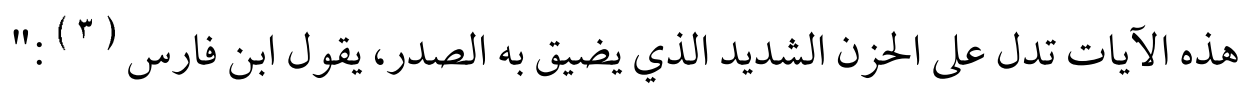
الكاف و الر اءو الباء، أصل صحيح يدل على شدة وقوة ( ؛ ).

و الكرب هو: الحزن والغم الذي يأخذ بالنفس، وجمعه كروب، وكَرَبه الأمر

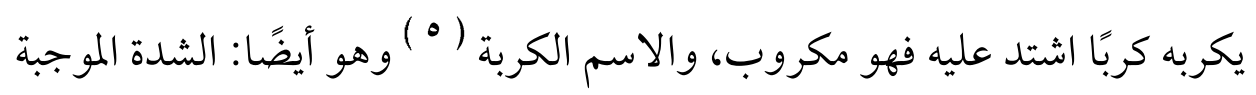

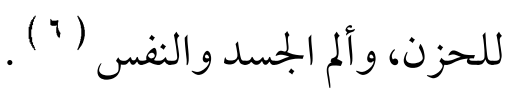
وأصل الكرب: الحبل الذي يُشد على الدلو ( v ) فكأن الكرب حبل أو

$$
\text { سورة الصافات، الآية:V7. }
$$

الإمام العلامة، اللغوي المحدث، أبو الحسين، أحمد بن فارس زكريا بن محمد بن حبيب $(r)$

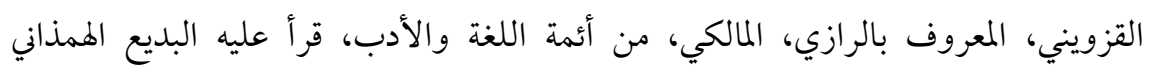
و الصاحب ابن عباد وغيرهما من أعيان البيان، أصله من قزوين، وأقام مدة في همذان، ثم انتقل

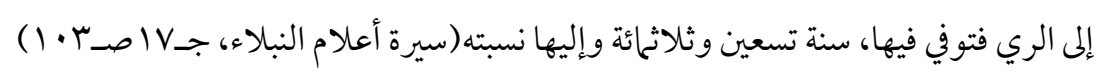

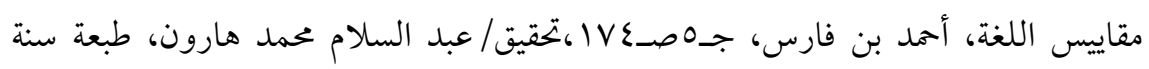

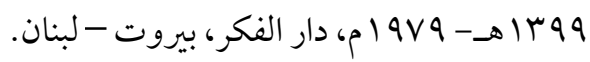

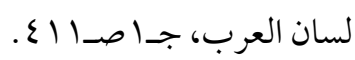

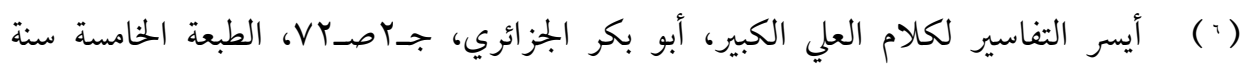

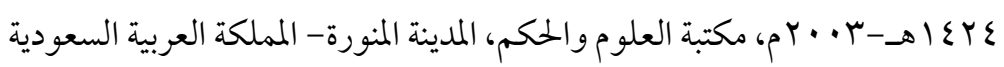

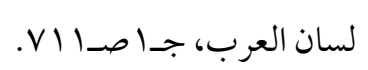




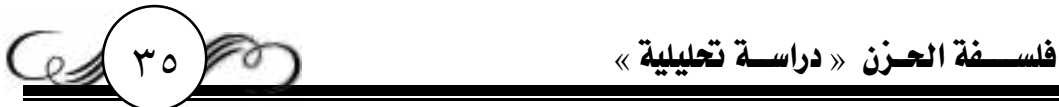

سلسلة تشد على الإنسان شدًا متكررًا دون توقف، فهو ضغط على النفس الإنسانية باستمرار من سيء إلى أسوأ، وهذه المعاني هي ما تحدث عنها القرآن الكريم في الآيات السابقة،فهي تتحدث عن أحداث مؤلمة متلاحقة، من غرق، وقتل، ثم إنها تشتد لحظة بعد لحظة، كحبل الدلو تمامًا، وهذا تصوير بليغ ودقيق لمعنى الكرب في القر آن الكريم.

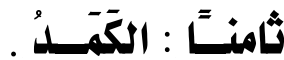

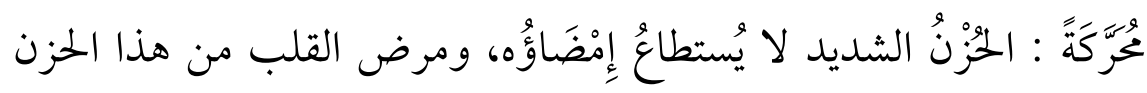
الشديد ( ' ) وهو الحزن المكتوم (r) وهذا الشكل من الحزن، عادة ما يخفيه صاحبه خلف قناع العبوسة و الكآبة.

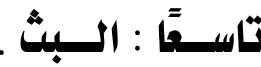

وردت مادة بث في القرآن الكريم في موضع واحد وهو قوله - تعالى- على

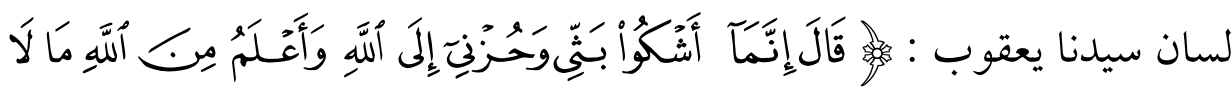

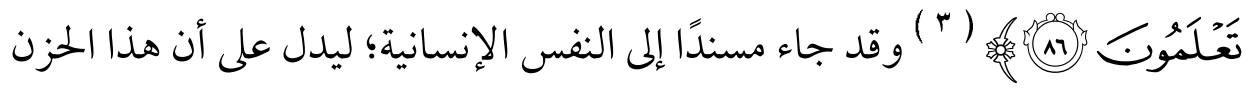
نابع من أعماق الذات، وقد عطف العام وهو: الحزن، على الخاص وهو: البث، تاج العروس من جواهر القاموس، مرتضى، الزَّبيدي،جهوصــ||(1،حقيق/بجموعة من المحققين، دار الهداية.

الصحاح تاج اللغة وصحاح العربية، أبو نصر الجوهري الفارابي،جـاصـاسم،تحقيق/ أحمد

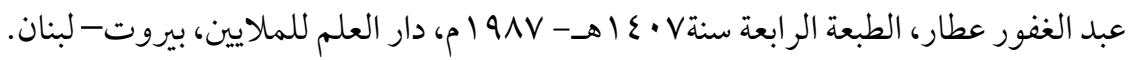

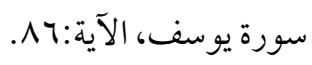




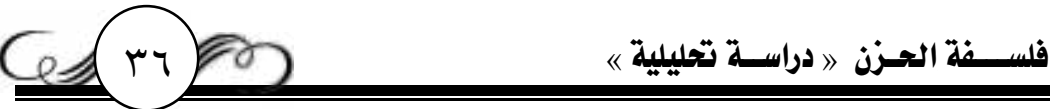

للتعميم، وشمول كل الأفراد: سواء كان حزنًا عظيًا، أو ما دونه، والمعنى: إنها أشكو حزني العظيم، وما دونه إلى الله لا إلى غيره من الناس،وإفراده بالذكر، اهتمامًا

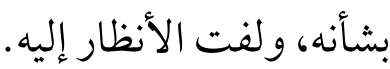

وأصل البث : ما في صدر الإنسان مما هو معتزم أنه يبثه وينشره ( 1 ) وهو أشد الحزن؛ لأن صاحبه لا يصبر عليه حتى يبثه أي: يفشوه (r أ لكونه متى أمكنه

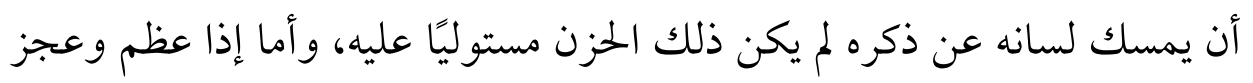
الإنسان عن ضبطه، وانطلق اللسان بذكره شاء أم أبى، كان ذلك بثًا، وذلك يدل

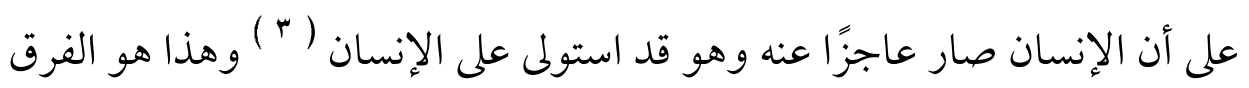
بينه وبين الهم.

بناءً على هذا التفصيل إذا أردنا أن نصنّف هذه الحقول الدلالية حسب قوتها وعمقها، وتأثيرها في النفس، فهي من الأدنى إلى الأعلى كالآتي: الحزن : حالة انفعالية متفاوتة قد تطول أو تقصر، تصاحبها حالة مزاجية سيئة مع تدهور صحي حتى يزول المسبب المادي أو المعنوي.

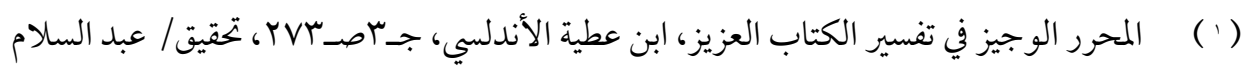
عبد الشافي عمد، الطبعة الأولى سنة Y \& ( اهـ، دار الكتب العلمية، بيروت- لبنان.

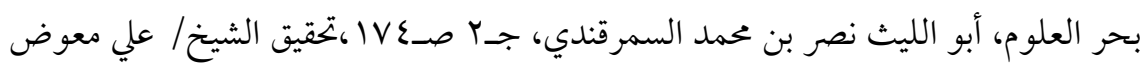

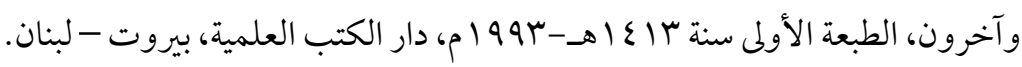

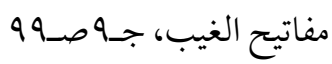




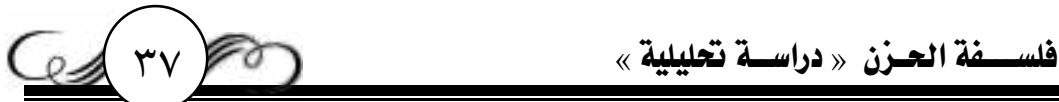

البؤس : حزن شديد قد يستمر في النفس؛ لحدوث مكروه، يصاحبه استكانة.

الأسى : حزن شديد؛ لفوات نافع، يصاحبه الغم و الندم أحيانًا.

الغم : حزن شديد مطبق مكتوم، يصاحبه الخوف والندم، مع وجود حالة من

الغضب في بعض الأحيان، وقد لا يعرف سبب وحقيقته، كما يصعب التخلص منه

و السيطرة عليه.

الكرب : حزن شديد يأخذ بالنفس على سرعة، ويضيق به الصدر، وحقيقته

أنه: الشدة المو جبة للحزن، و ألم الجمسد والنفس، نتيجة حدث خاطف.

الكمد : حزن شديد لا يستطاع إمضاؤه، تظهر آثاره في شكل عبوسة على

$$
\text { وجه الإنسان. }
$$

الكآبة : حزن شديد، تظهر آثاره على هيئة انكسار في الوجه خاصة.

الهم : حزن يطول حتى يذوب البدن، فهو أصل في الذويان، يقال: أهني

المرض، أي: أذابني، وحقيقته: الفكر في إزالة المكروه الذي يرد على القلب في

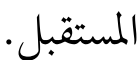

البث : هو أشد الحزن؛ لأن صاحبه لا يصبر عليه حتى يبثه أي: يخبر به

وينشره، وهو أشد من الهم ودون الأسف.

الأسف : حزن قوي، يصاحبه غضب شديد، وأصله حالة تعكس مشاعر

الحزن الأليم البالخ منزلة وراء الغضب، وذلك لحدوث شيء مؤلم غير متوقع، وهو أعلى درجات الحزن، و أشده وطأة على النفس الإنسانية. 


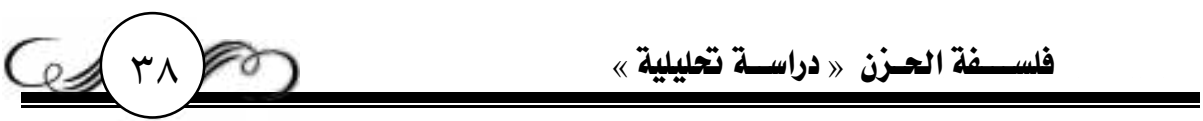

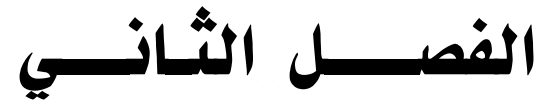

$$
\begin{aligned}
& \text { أسـباب ودوافـع الحـزن ، وموقف الإســلام منــهـ } \\
& \text { ويتكورن مرن مبحثن } \\
& \text { المبحـثُ الأول: أسـبـاب ودوافــع الحـزنز . } \\
& \text { المبحث الثاذي: موقـف الإسـلام مز الحزز . }
\end{aligned}
$$




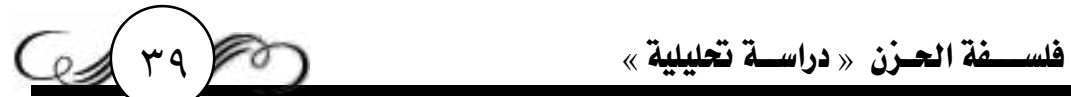

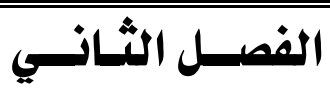

أسـباب ودوافــع الحــزن، وموقــف الإســلام منـــهـ

المبحث الأول : أسـبـاب ودوافـــع الحسـزن .

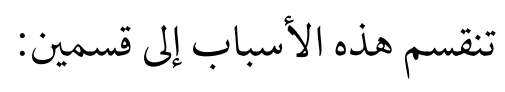

إحداهما: أسباب مستقرة ومتو طنة "باطنية المنشأ وليس لها ححفز ظاهر".

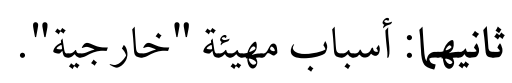

أما الأول : فإن بعض الناس يوجد عندهم استعداد للحزن، ولديهم في فطرهم الميول له، وهذا ما نلمسه في الواقع، ونشاهده في الحياة، وخاصة ما لديهم حساسية مفرطة، ومشاعر جياشة، وعاطفة رقيقة صادقة.

وقصة هذه الأحاسيس العاطفية، تبدأ بحب غخلص أو شعور بالاهتمام ينتهي إلى حزن عندما يتحول الشعور بالاهتحام إلى إحساس عاطفي مخزن - كالشوق

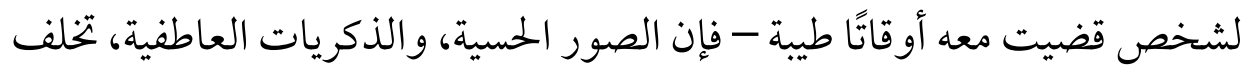
إحساسًا بالخسارة، يمكن أن يجعل القلب يغوص في حزن عميق.

فبقاء هذه الأحاسيس العاطفية أكثر من اللازم، يسبب "نزيفًا للقلب"

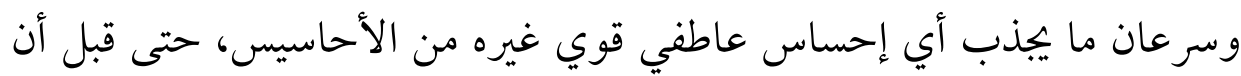
تشعر بأنك غائص في مستنقع الكآبة. فالعقل يفرط في تماثله مع الذكريات وتقمصها - معطيًا أهمية أكبر لما كان

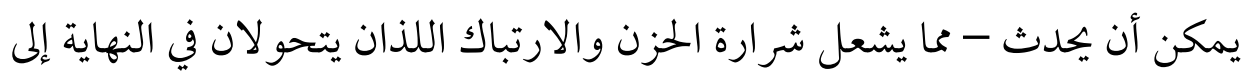


بؤس واكتئاب، وإن التحكم في العاطفة لا يعني القضاء على شعور الحزن أو كبحه، وعلى الإنسان أن يتعلم كيفية التحكم بمشاعره الحساسة، وعو اطفه المتأججة التي لا يمكن أن تتحول إلى حزن.

وهذا التحكم يكون عن طريق تقنية التماسك السريع بحيث تمكّّن قيم قلبك الجوهرية العميقة من التعبير عن نفسها، وبذلك فإنك تكرّم ذكرياتك المتعلقة

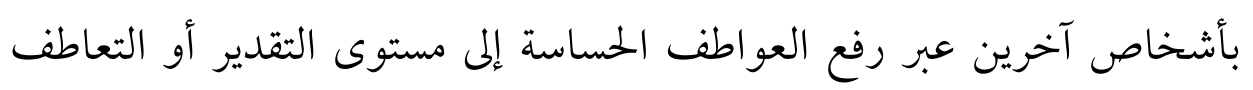

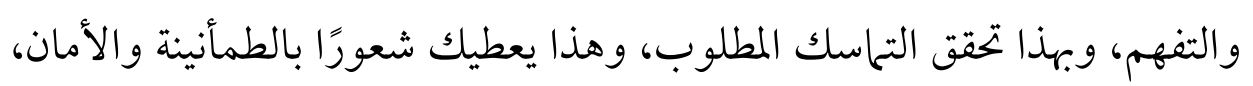
ويشرع في إعادة ترميم قوتك العاطفية المجهدة، كما يمكن أن يزودك بمفاهيم جديدة عن كيفية التحول نحو الأمام ( ' ). من مشكلات العاطفة الجامحة "التعاطف"مع الآخر حال حزنه، وهو أمر قد يوقع في مصيدة الأحزان؛ لأنه يجعل المرء مندبجًا مع المصاب بهذا الداء- اهتمامًا بحاله- إلى درجة المشاركة، وفي الو اقع إن هذا الموقف يُعجز الإنسان عن المساعدة، ويقلص قدرته على الاهتمام، فعندما يرث الذهن حال شخص آخر، فإنه غالبًا

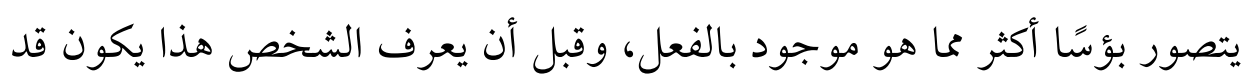

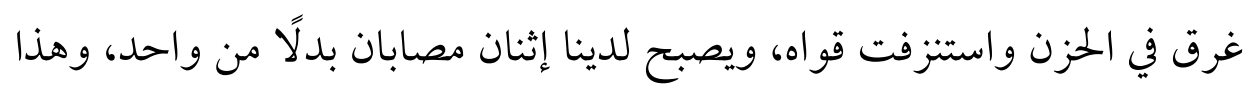
من جراء التعاطف الزائد.

(') التخلص من الاكتئاب، دوك تشيلدر، د.ديبورا وزمان، صــ||(، ترجمة/ عبير الدجاني، طبعة

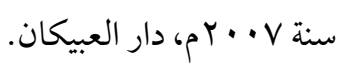




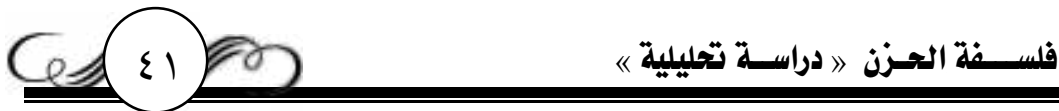

ومن الأسباب المستقرة والموطنة للحزن، عامل الوراثة، فإن الدراسات

تثبت وتؤكد على مدى التأثير الجيني في إمكانية الإصابة بالحزن والاكتئاب، كما

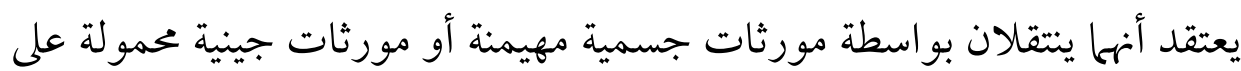

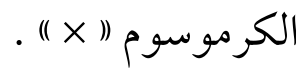

يقول " دوك تشيلدور والدكتور ديبوراروزمان" : " لا بد أن ننظر إلى العوامل الور اثية التي قد تجدد نسبة قابلية الشخص للإصابة بالاكتئاب وذلك عن طريق تفحص التاريخ المرضي للعائلة، وتتبع الإصابة بالاكتئاب عبر الأجيال

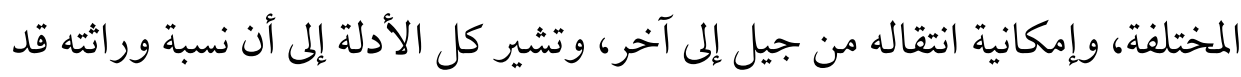
تصل إلى خمسين في المئة، وهكذا فإن إمكانية تعرض أي شخص مرهونة بها ورثه من

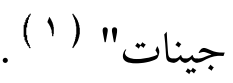
وقد أجريت دراسات بالفعل، وتأكد الباحثون - بها لا يدع بجالًا للشك التأثير الجيني على إمكانية الإصابة بهذه الحالة، فمن هذه الدراسات، ما تم على التو أم المتطابق، ولقد ثبت أن إصابة أحد التوأمين تعني إصابة الآخر بنسبة خمسين بالمائة، معنى هذا أن هناك تأثيرًا جينيًا قويًا يؤكد الدور الكبير الذي تلعبه الجينات في احتمالية الإصابة.

كما تشير الدراسات، أن أقارب الشخص المصاب بالاكتئاب معرضون بدورهم بالإصابة بالمرض بنسبة عشرين بالمئة،أما احتمالية إصابة الأطفال لأبوين (1) الحزن الخبيث، صـوها. 


\section{مصابين، فإنها تتجاوز الخمسين بالمئة.}

و إذا كان أحد الو الدين أو أحد الأشقياء مصابًا بالحزن والاكتئاب، فإِن نسبة

إصابة الابن أو الشقيق تتصاعد عن الشخص العادي، وترتفع هذه النسبة إلى خمسة أضعاف إذا كان القريب قد أصيب قبل عمر العشرين.

كما أجريت دراسة على بعض الأطفال الذين يعيشون مع عائلة لا يتمون إليها، ولا تربطهم بهم صلة قرابه؛وذلك لتوضيح العلاقة بين الحزن والاكتئاب والعامل الجيني الوراثي، وقد أظهرت النتائج أن هؤلاء الأطفال الذين ولدوا من أب أو أم مصابين، معرَّضون للإصابة رغم وجودهما ضمن عائلات أجنبية لا يعاني أفرادها من هذا الداء وذلك بنسبة أكبر من أولئك الذين ولدوا من أب وأم غير

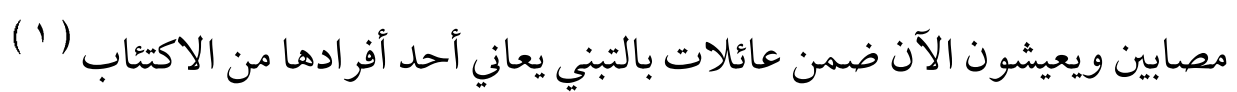
ومن هذا القسم - أيضًا- بعض الأمراض التي قد تكون سببًا في الإصابة بالحزن مثل: الخلل في الناقلات العصبية المسئولة عن تنظيم الإيعازات العصبية من خلايا الدماغ، ومن هذه الناقلات " مادة السيروتونين" والتي يؤدي نقصها إلى ظهور أعر اض الحزن والاكتئاب.

هذا الخلل إنما يحدث بين خلية وأخرى، فإذا أرادت خلية أن تتصل بأخرى ترسل هذه الناقلات العصبية إلى الخلية المستلمة،حيث أن الخلايا لا تتصل فيما بينها مباشرة، وإذا أوصلت الرسالة إلى الخلية المستلمة عن طريق المستقبلات، يعود

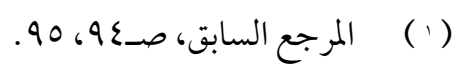




\section{فلســفة الحـزن 》 دراسـة تحليلية 《)}

الناقل العصبي إلى الخلية المرسلة وتمتصه فيحدث النقص الذي أدى إلى الشعور بالخزن.

ثم باقي الأمراض، ونخص بالذكر الأمراض المزمنة التي لها تأثير على الحالة النفسية وليس على المريض فحسب، بل على الأسرة ككل. و سبب معاناة المريض، وإصابته بداء الحزن عاملان :

الأول:عامل خارجي يتمثل في تغير حالته البدنية والحياتية، كانخفاض قيمة الذات؛ لإصابته بالهزال والعجز عن مجارات الحياة اليومية؛بسبب الإعياء و الفتور وعدم التركيز، ثم الآلام الناتجة عن تأثير بعض الآلات المستخدمة للعلاج. الثاني: عامل داخلي تسببه بعض الأدوية ويسمى " الحزن والاكتئاب العلاجي المنشأ" وهذه الأدوية مسئولة عن اضطراب المزاج؛ لكونها مثبطة للنواقل العصبية، فبعض الأدوية تعمل على إخفاض أو القضاء على هرمون "السيروتونين" الناقل العصبي المسئول عن السعادة في جسم الإنسان، أو على الأقل فإنها تقلل مستويات التواصل أو الاستثارة والتحفيز العصبي، وقد تقوم بتعديل الإشارات الكهربائية، ولذا نجد في المنشور المرفق مع الدواء من ينبه - وتحت عنوان الأعر اض الجانبية- أن هذا العقار قد يسبب اضطر ابات المزاج.

أما السبب الثاني من أسباب ودوافع الحزن وهو الحافز أو المثير الخارجي، كالحزن الناشئ عن اضطراب التكيف النفسي مع الأزمات التي تضع الإنسان في حالة من عدم الراحة، نتيجة تهديدها لأمنه وسلامته و استقراره، فتحدث ججموعه 


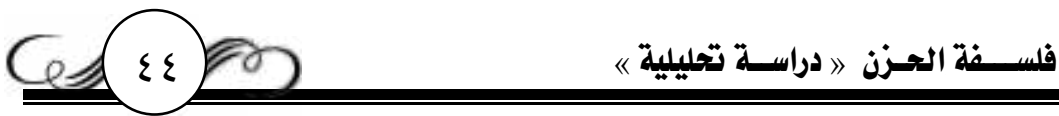

من التغيرات النفسية كالحزن والقلق والغضب والإحباط،فعندما تكون إمكانيات الشخص محدودة لا تفي بمتطلبات الواقع، وهنا يقع الخلل الناتج عن عدم التوازن، ويتعرض الفرد لمجمو عه من المو اقف والمشكلات، وهذه هي طبيعة الحياة،

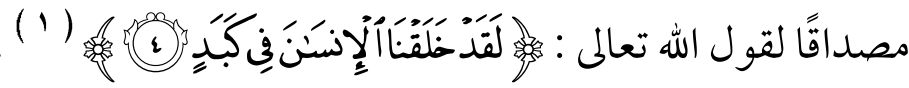
وإذا أردنا أن نلمس بعضًا من هذه الأزمات، فلنستعرض الآيات القرآنية التي تشير إلى مجموعه من الأبعاد النفسية التي تجسد الواقع بها فيه من صراعات وهموم.

ففي المحيط الأسري، يعرض القرآن الكريم ما دار من أحداث، وما وقع من أزمات بين عائلة نبي الله يعقوب -اليَلِّلَّة- وكيف أصابه ذلك بداء الحزن، ففي سورة يوسف آيات ودروس ينبغي أن نتدبرها، استجابة لقول الله تعالى :

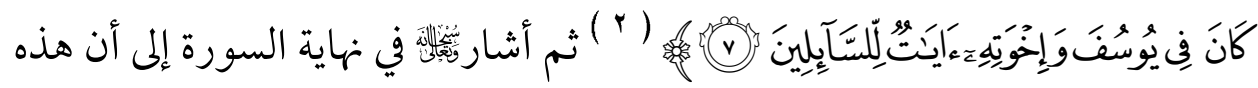
الأحداث فيها من العظات البالغات ما يستدعي الوقف عندها؛ حتى يستفيد الإنسان

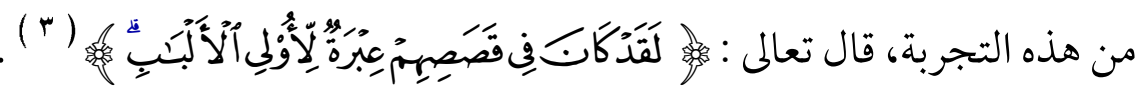
فعلى الرغم من الأخذ بالحيطة والذر في قول نبي الله يعقوب لسيدنا يوسف : و

$$
\text { سورة البلد، الآية:ع. سورة يوسف، الآية:v. }
$$




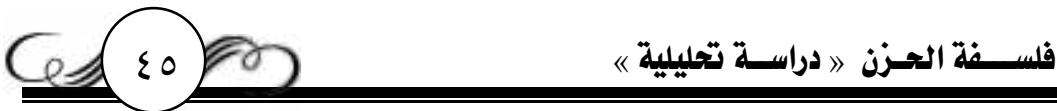

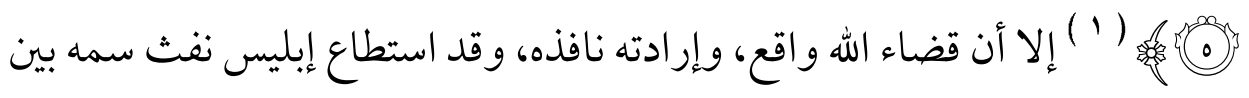

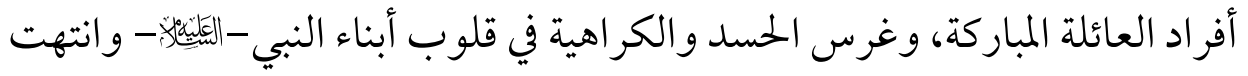
المؤامرة إلى أنه يجب التخلص من يوسف حتى يخلص لهم قلب أبيهم، يقول الله تعالى :

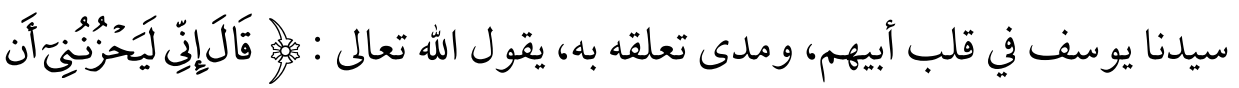

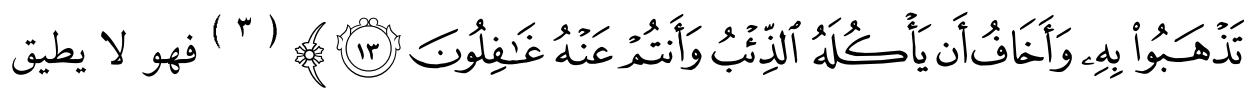
فراقه ولا حتى غيابه من أمام عينيه، ولا شك أن هذه العبارة زادت نار أحقادهم وضغائنهم تأججًا؛ لكون بلوغ حبه له إلى درجة الحزن لفراقه ولو لبعض يوم، وإنها ذكر الحزن ليصرفهم عن طلبهم إذ أن من شأن الأبناء البررة أن يتقوا ما يدخل الحزن على أبيهم، ولكنهم لم يفعلوا، وقدموا على ما سولت لهم أنفسهم، وزينه لهم الشيطان، مع العلم بأن في كلام نبي الله يعقوب تلميح يكشف ما خططوا له، وما تكنه صدورهم لعلهم ينتهون وذلك في قوله: كان لهم قلوب يفقهون بها لتم اختيار وسيلة أخرى غير الذئب، أو على الأقل أحبكوا الفرية ومزقوا القميص، وكأن الذئب هو الفاعل، من باب إقناع الأب أن

$$
\text { سورة يوسف، الآية:0. سورة سوة يوسف، الآية:9. }
$$




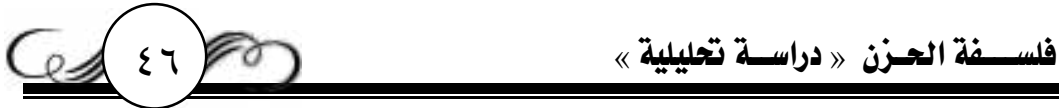

ما توقعه وأخبر به أصبح مققًا على أرض الواقع، ولكن الحال يؤكد على افترائهم، ونزل البلاء على نبي الله يعقوب، وخيم عليه الحزن حتى أصابه ما أصابه من وراء

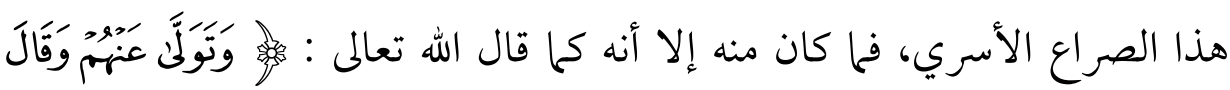

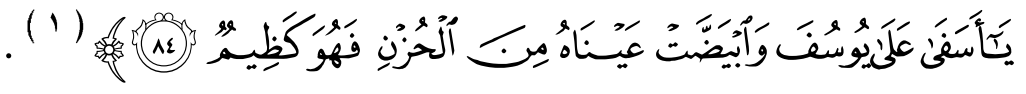
ومن الأمثلة القرآنية التي تعرض أحداثًا أثرت بالفعل على الواقع النفسي

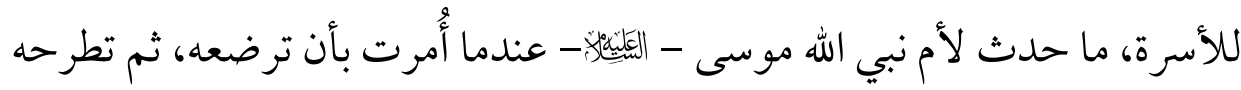

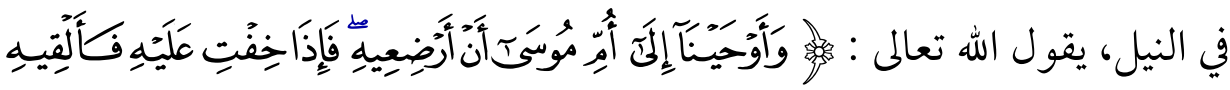

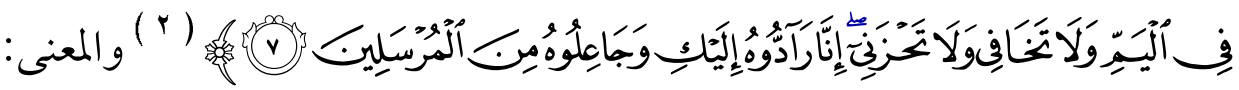
لا تخافي من هلاكه، ولا تحزني بسبب فراقه، ولكن قلب الأم وخوفها وقلقها على صغيرها، جعلها تنسى وصية الله بعدم الحزن والخوف؛ لأن عناية الله تلاحظه،

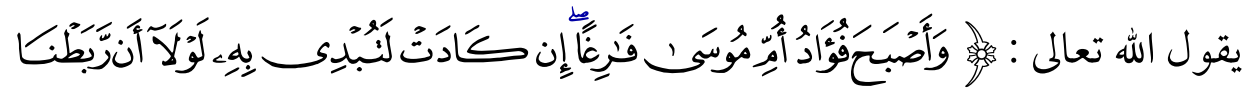

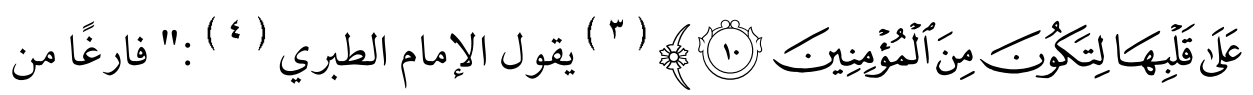

$$
\text { سورة يوسف، الآية: عـ. سورة القصص، الآية:v. }
$$

محمد بن جرير بن يزيد الطبري، أبو جعفر: المؤرخ المفسر الإمام، ولد في آمل طبرستان سنة أربع وعشرين ومائتين من الهجرة، واستوطن بغداد وتوفى بها، من مؤلفاته: أخبار الأمم والملوك، فيك وجامع البيان في تفسير القرآن، واختلاف الفقهاء، والمسترشد في علوم القرآن وغيرهم، توفى

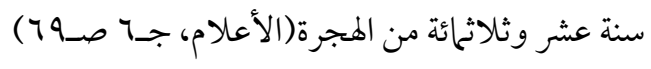


الوحي الذي أوحى الله إليها حين أمرها أن تلقيه في البحر، ولا تحاف و لا تحزن" ( ( ) يقول ابن قتيبة ( r ):" وهذا من أعجب التفسير، كيف يكون فؤاذها من

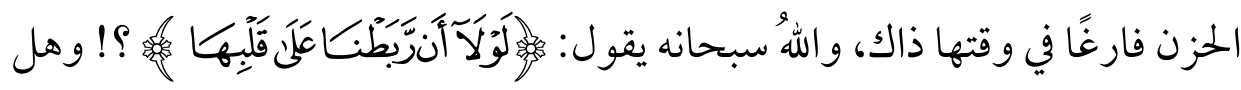
يُبَطُ إلا على قلب الجازع والمحزون؟! والعربُ تقول للخائف والجبان: "فؤاده هواء" (r) ومن رحمة الله بهذه الأم الثكلى، أن رُدَّ عليها ولدها؛ ليفرج كربها، ويذهب

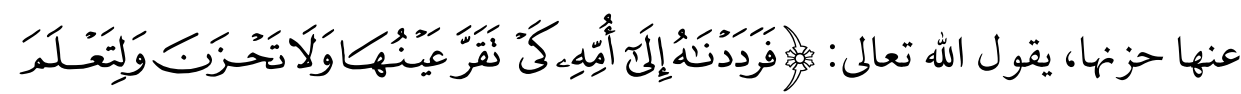

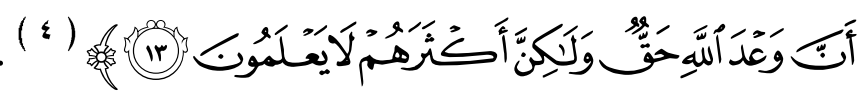

ومن عوامل الحزن الخارجية: عدم إجابة دعوة الداعي إلى الحق، وإلحاق

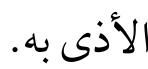

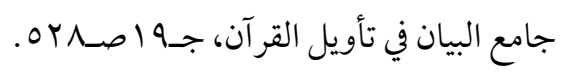

عبد الله بن مسلم بن قتيبة الدينوري، أبو محمد النحوي اللغوي، كان فاضلًا ثقة،من أئمة

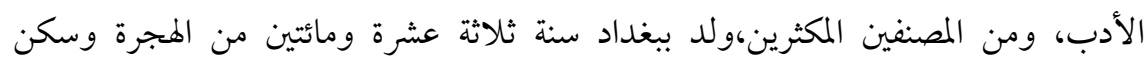
الكوفة،ثم ولي قضاء الدينور مدة، فنسب إليها، وتوفي ببغداد سنة ست وسبعين ومائتين(طبقات

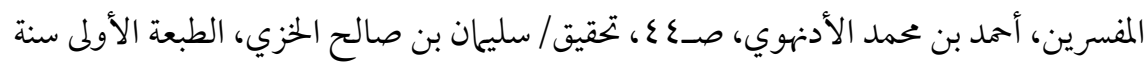
VI إهـ- 1997 (م) مكتبة العلوم والحكم، المملكة العربية السعودية؛ وفيات الأعيان وأنباء

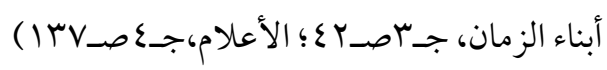

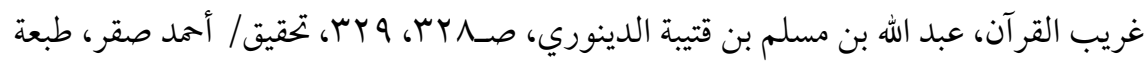

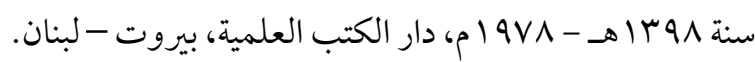

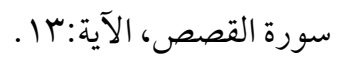




\section{6}

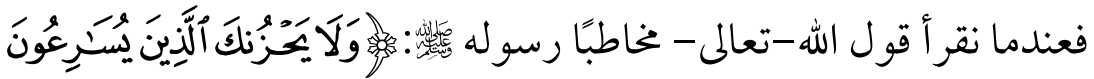

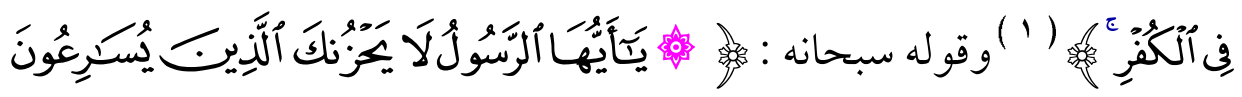

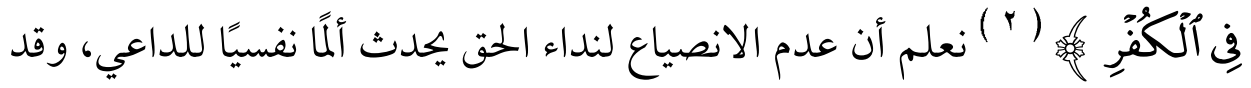

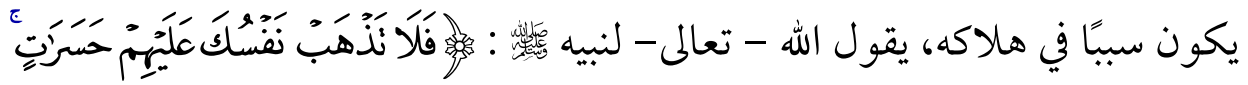

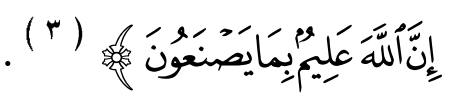

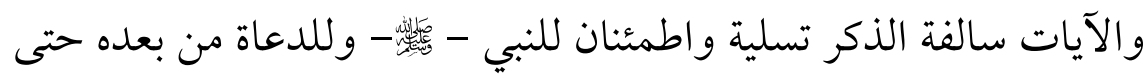
لا يتأثروا بها يروه من صدود عن الحق وكفر ونفاق، وإن دلت هذه الآيات على بلى شيء، فإنما تقطع بصدق الدعاة وحرصهم على مصلحة المدعويين، ففي هذه الدعوة نجاة وفوز عظيم.

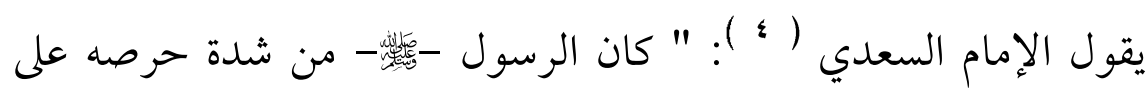
الخلق، يشتد حزنه لمن يظهر الإيالن، ثم يرجع إلى الكفر، فأرشده الله -تعالى - إلى أنه

$$
\text { سورة آل عمر ان، الآية: } 1 \text { سورة المائدة، الآية:اع. }
$$

عبد الرممن بن ناصر السعدي، النجدي مفسر، محدث، فقيه، أصولي، متكلم واعظ، ولد في

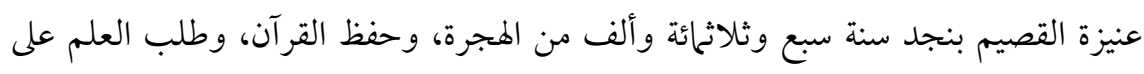

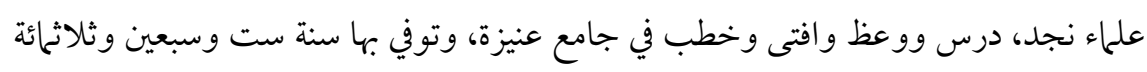

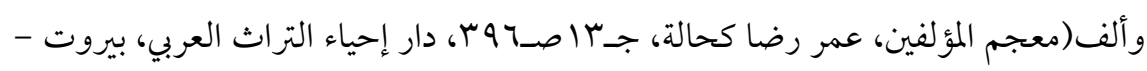




\section{Ges:}

لا يأسى ولا يحزن على أمثال هؤلاء فإن هؤلاء لا في العير ولا في النفير، إن حضروا لم ينفعوا، وإن غابو الم يفقدوا، ولهذا قال الله - تعالى - مبينًا للسبب الموجب لعدم

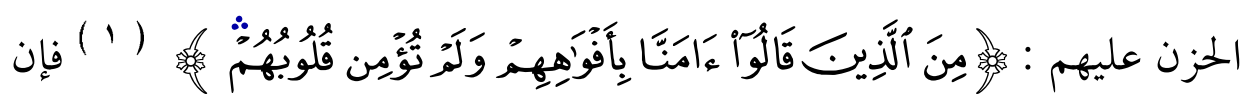
الذين يؤسى ويجزن عليهم، من كان معدودًا من المؤمنين، وهم المؤمنون ظاهرًا

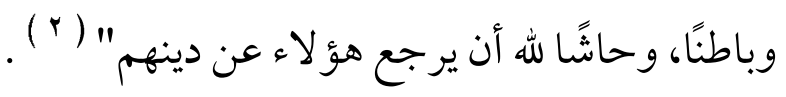
ومن عادة المعاندين المعرضين عن الحق، إلحاق الأذى القولي والفعلي

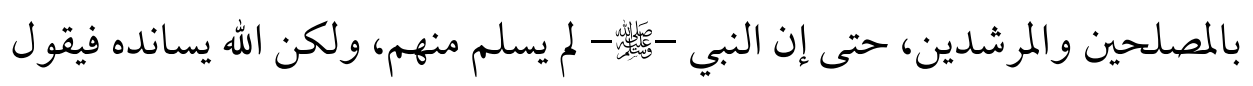

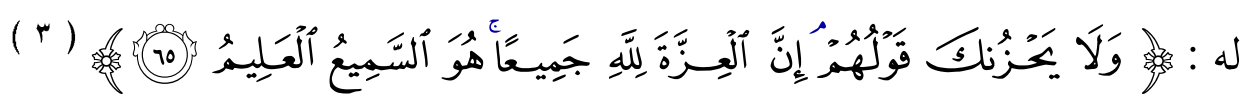
وهذه الآية نزلت في المعاندين الذين هددوا وزعموا أنهم أصحاب التبع لهربع والمال،وسعوا في قهره، وإبطال أمره،نشروا عنه الأكاذيب التي تضر بدعوته،

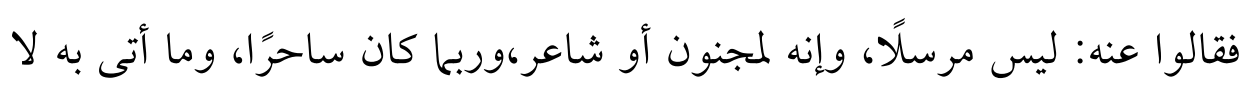
يخرج عن كونه أساطير الأوليين، وقد تلقاه عن غيره. يقول الإمام الرازي ( ؛ ) :"واعلم أن الإنسان إنما يحزن من وعيد الدهنه الغير،

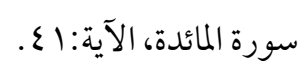

تيسير الكريم الرمن في تفسير كلام المنان، عبد الرهمن بن ناصر بن السعدي، صـابrاك،

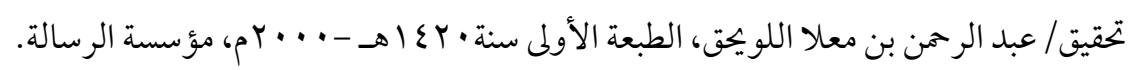

$$
\text { سورة يونس، الآية:70. }
$$

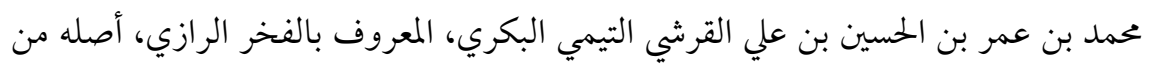

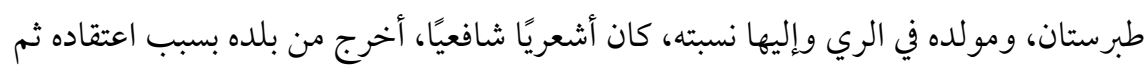
$=$ 


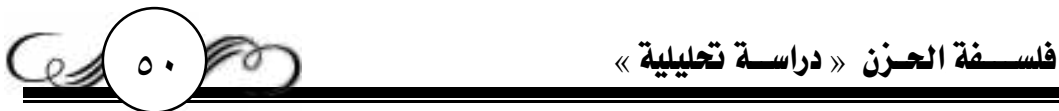

وتهديده ومكره وكيده، لو جوز كونه مؤثرًا في حاله، فإذا علم من جهة علام الغيوب أن ذلك لا يؤثر، خرج من أن يكون سبًا لحزنه، ثم إنه -تعالى - كما أزال

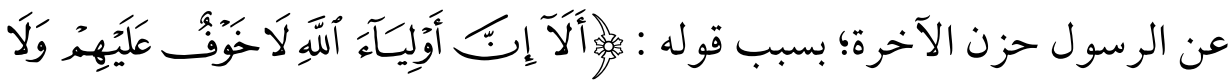

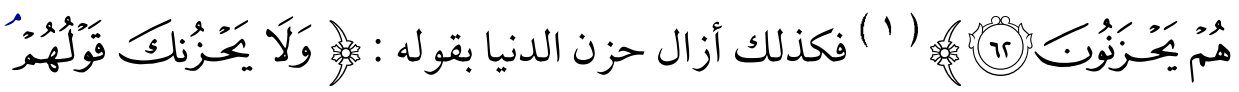

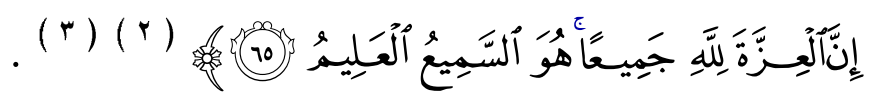
ومن هذه العوامل: الجانب الاقتصادي المتردي، المسبب عن هالك مال الإنسان، وهذا مما يؤثر على نفسية رب المال، وقد يسبب له الوفاة، ولنا في أمثال القر آن العبرة والعظة، فعندما نعيش مع قصة صاحب الجنتين، ندرك أنه أخذ يقلب كفيه كناية عن الحزن والندم الشديدين؛ لاضمحلال وهلاك جنته، عقوبة له على شر كه بالله، وتفاخره وتكبره بنعم الله ونسبها إلى قدرته، فكان جزاؤه كما قال القرآن

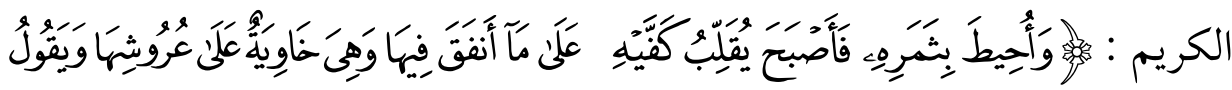

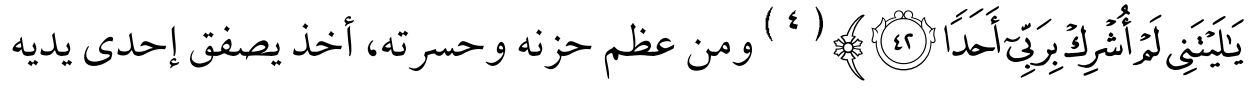

قصد ما وراء النهر ثم عاد إلى الري وكان بها طبيب حاذق له ثروة ونعمة، يذكر ابن كثير أن الكرَّامية وضعوا عليه من سقاه سماً فمات ، وكانت وفاته سنة ست وستمائة من الهجرة (البداية

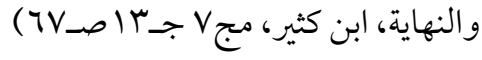

$$
\begin{aligned}
& \text { سورة يونس، الآية: بال } \\
& \text { سورة يونس، الآية:70. } \\
& \text { مفاتيح الغيب،جـ Vا صـع.1. } \\
& \text { سورة الكهف، الآية:بع. }
\end{aligned}
$$




\section{فلســفة الحـزن 》 دراسـة تحليلية 《)}

على الأخرى أو يبدو ظهرهما ثم بطنها ويكرر ذلك، وإنما يفعل هذا حزنًا على ما قدمت يداه، وأنفق في هذه الجنة الخاوية الساقطة على عروشها، وهو تصوير بديع لما

$$
\text { اعتراه من غم وهم وحسرة وندامة . }
$$

فقد جرت عادة الإنسان أنه إذا نزل به ما يدهشه ويؤلمه ، أن يعجز عن النطق في أول وهلة، فإذا ما أفاق من دهشته ، بدأ في النطق والكلام ، وهذا ما حدث من ذلك الرجل - كما صوره القرآن الكريم - فإنه عندما رأى جنته، وقد تحطمت، أخذ يقلب كفيه حسرة وندامة دون أن ينطق، ثم بعد أن أفاق من صدمته جعل يقول:

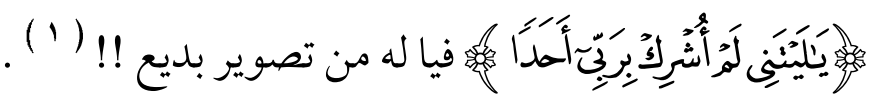

و مثل هذا المتحسر الحزين على هلاك ماله، أصحاب الحديقة، أولئك الأشقياء الذين جهلوا حق الله في مالهم، ولم يؤدوا زكاة ثحارهم، فحق عليها قول ربنا، فأصبحت جنتهم كالليل المظلم البهيم، لا ترى فيها إلا ما تخلفه النار من رماد بعدما كانت واحة خضراء مثمرة، تتدفق فيها مياه الأنهار، وتطوق النفس إلى هو اها العليل، ونزهة بجلسها، وطيب غنائها، ولو أنهم ساروا على نهج والدهم، و أنصتوا إلى نصيحة أرجحهم و أعدلهم، ما مس رأس مالهم السوء، يقول الله تعالى : إِنَّا

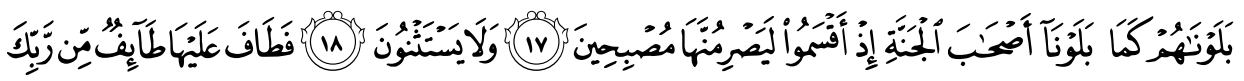

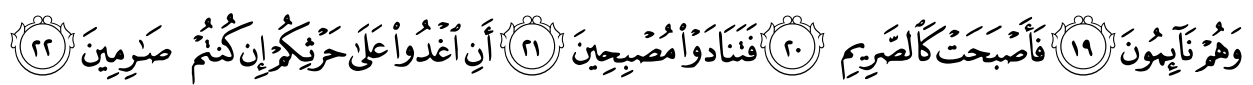

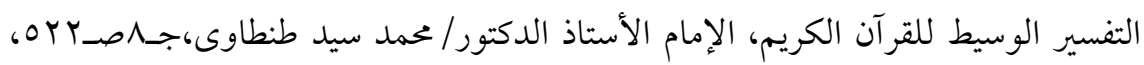

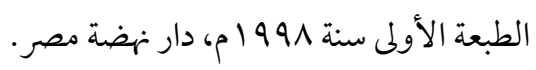




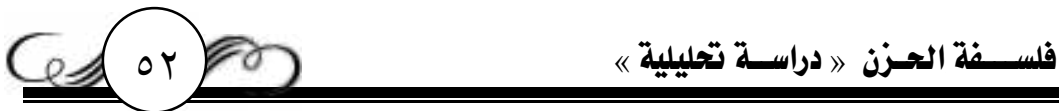

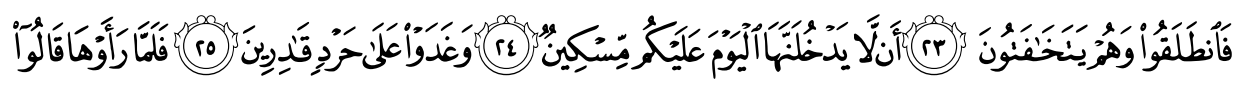

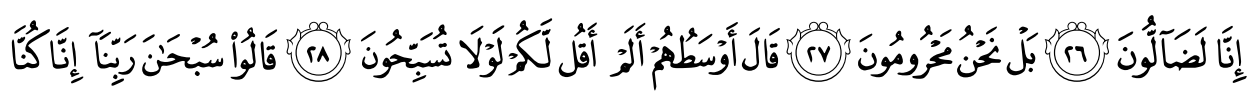

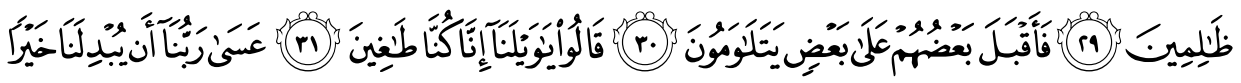

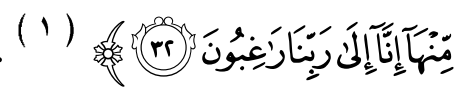
ولا شك أن ضياع مال الإنسان يحزن، ولا أدل على ذلك من هذا الإشفاق

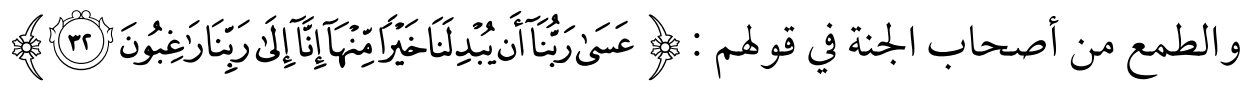
لعل الله يعطينا أفضل منها؛ بسبب توبتنا وتوجهنا إليه سبحانه. ومن الجانب السياسي في القرآن الكريم: أنه دعا إلى الجهاد في سبيل الله، والدفاع عن المجتمع المسلم، ويترتب على ذلك اندلاع الحروب، وهنا يو جه القرآن الكريم الفئة المقاتلة، ويرشدهم إلى كيفية التخلص من الأزمات التي تو اجهرم في

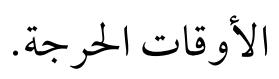

ومن المواقف التي يُشِبّت فيها القرآن الكريم المؤمنين ويحرضهم على القتال، وفي نفس الوقت يبشرهم بالنصر شريطة ألا يتسرب إلى نفوسهم الحزن والألم، قوله

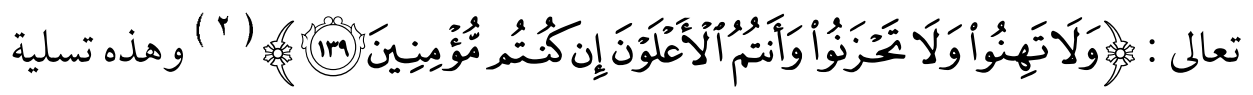

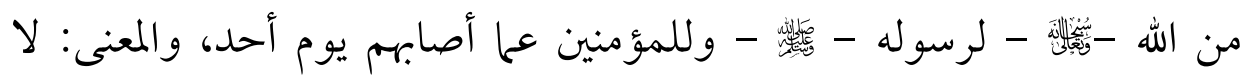
تضعفو اعن الجهاد لما أصابكم أي أورثكم ذلك وهنًا وجبنًا، فعفو الله عنكم يزيل

$$
\begin{aligned}
& \text { سورة القلم، الآيات: V V Y r . . } \\
& \text { سورة آل عمران، الآية: وبا . }
\end{aligned}
$$




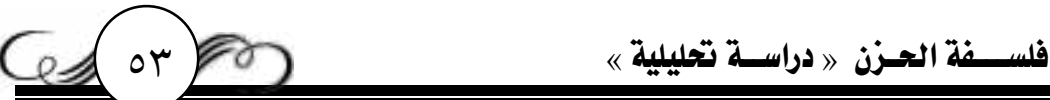

ما نالكم من غم القتل والجراح، وفوات الغنيمة والظفر، والجزع من إشاعة أن

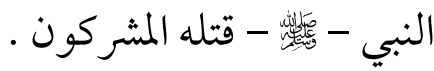

وإذا كان اله قد جازاهم بهذا الغم؛ فذلك لكى يتمرنو اعلى نوائب الدهر،

فلا يحصل لهم الحزن في المستقبل؛ لأن من اعتاد الحوادث لا تؤثر فيه ( 1 لقال الله

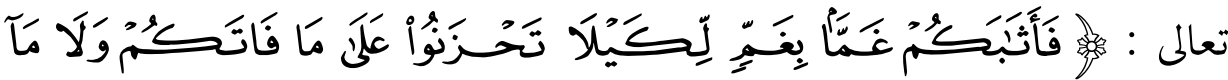

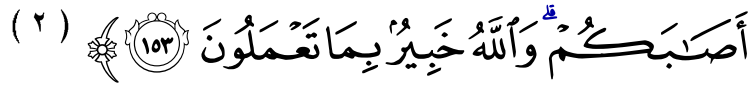

ومن العوامل الخارجية : الموروثات الاجتماعية أو الخلفية الثقافية، كما نلاحظها عند: اليهود و النصارى والشيعة . فمن عادات اليهود المتأصلة حزنهم حتى البكاء، والنحيب على خلفية

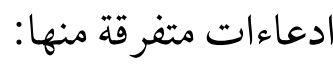

1 - الحداد على خراب معبدهم القديم أو ما يطلقون عليه " الهيكل السلياني " ، ويسميه العرب القدسيون "حائط المبكى " .

r - دعوة التوراة لليهود إلى النظر والندم على ما اقترفته أيديهم تجاه السيد المسيح ، وهذا يستدعى الحزن الدائم، يقول زكريا في سفره : "وَأُفِيضُ عَلَى بَيْتِ

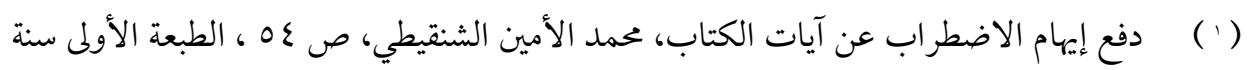
VI إهـ- 1979 1م؟ مكتبة ابن تيمية، القاهرة - مصر .

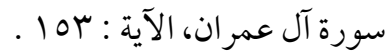




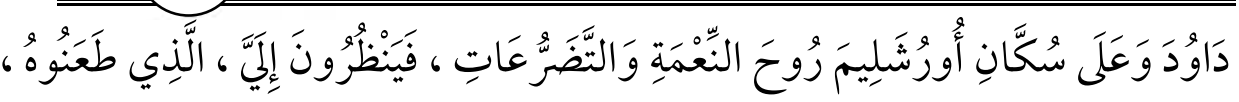

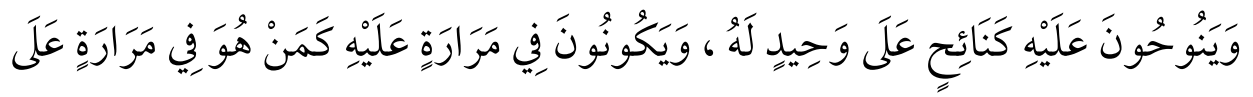
(1) (1)

وحزنهم هذا مثل حزنهم على قتلهم للملك " يوشيا " الذي حزن الشعب

عليه حزنًا شديدًا لم يكن مثله منذ قيام إسرائيل على حد تعبير التوراة التي تقول "في

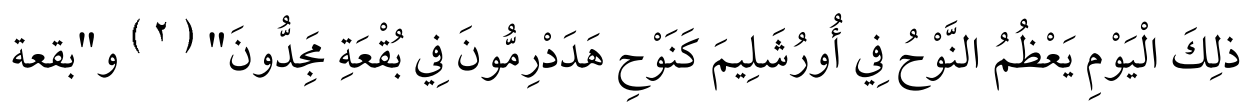
مجدون" هو المكان الذي قتل فيه "يوشيا" ويعتقد شراح التوراة: أن هذه إشارة للمسيح الذي ناح عليه الجميع (r" ). فالسمة الغالبة على توراة اليهود هي الحزن أفرادًا أو جماعات، فهي تقول:

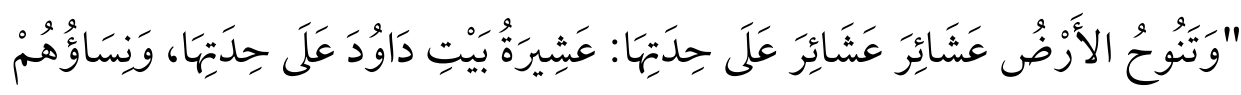

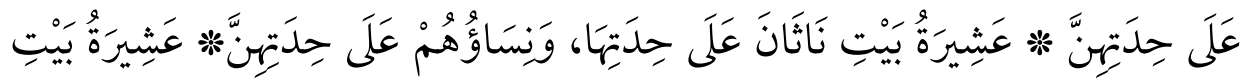

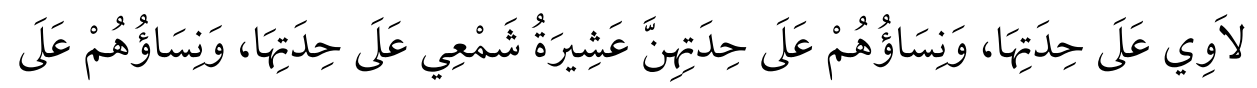

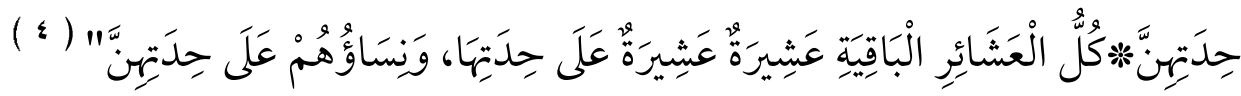
وفى هذا النص توجه التوراة الحديث إلى القادة والذين بدورهم يعملون على ترسيخ

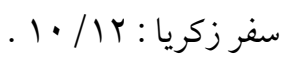

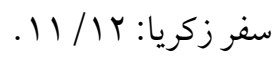

$$
\begin{aligned}
& \text { الأنبياء الصغار "زكريا" القس/ انطونيوس فكري ، ص } 1 \text { اله }
\end{aligned}
$$

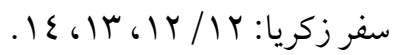




\section{6}

$$
\text { هذا الشعور في رعاياهم ومن تحت إمرتهم · }
$$

* ويُعَدُ الحزن أيضًا في النصرانية مشاركة للمسيح في أحزانه، ففي المزامير

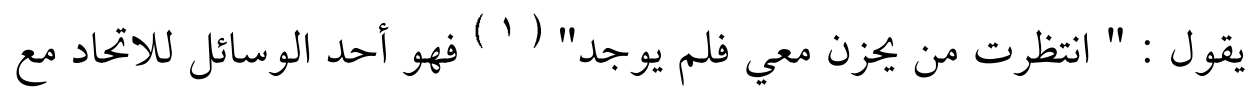

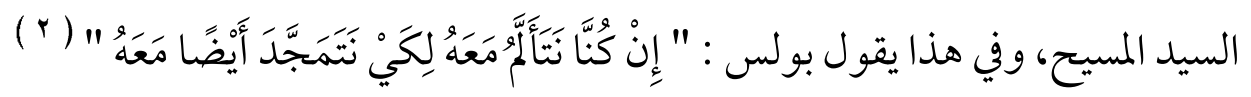
وهو أيضًا نوع من الأدب والاختبار، يقول القديس مار إسحق السرياني :

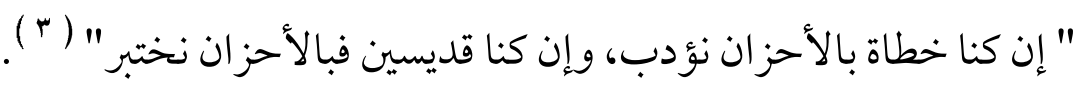

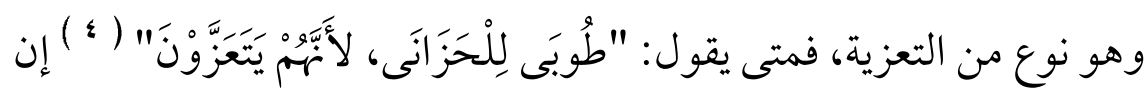

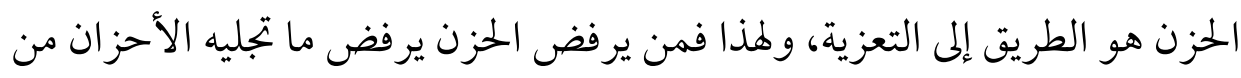

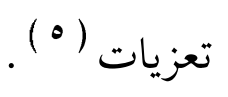

فالتعزية التي يجلبها الحزن هي راحة حقيقية، ومتعة غير زائلة، كقول المرنم

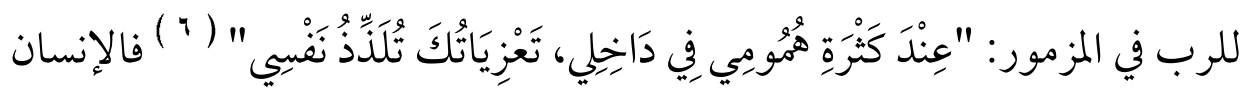
الحزين في النصرانية موضع اهتحام الرب وانشغاله كما في اشعياء: " كَإِنْسَانِ تُعَزِيِه

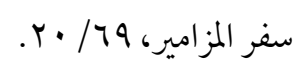

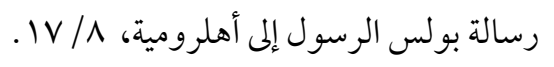

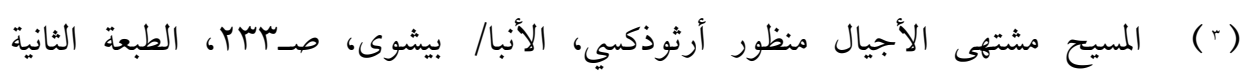
سنةV · F م، الناشر مطر انية دمياط وكفر الشيخ والبراري ودير القديسة دميانة.

$$
\begin{aligned}
& \text { إنجيل متى، / / ع. } \\
& \text { المسيح مشتهى الأجيال منظور أرثوذكسي، صـبس بـ. }
\end{aligned}
$$

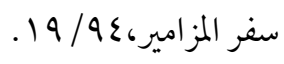




\section{فلســفة الحـزن 》 دراسـة تحليلية 《) 07 C)}

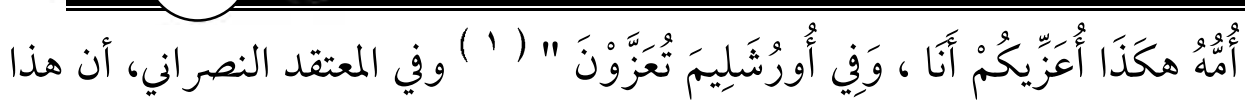

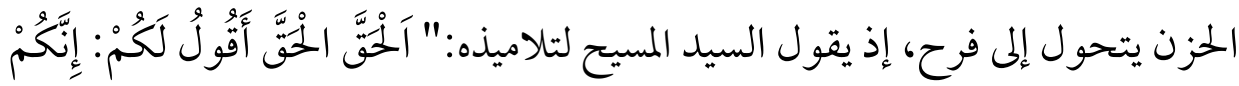

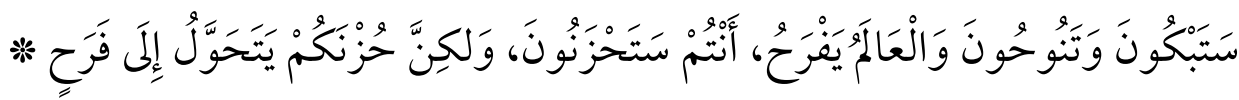

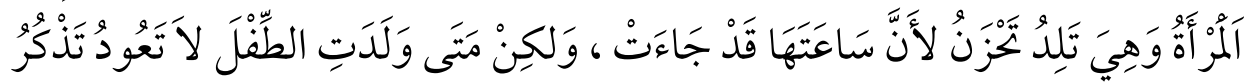

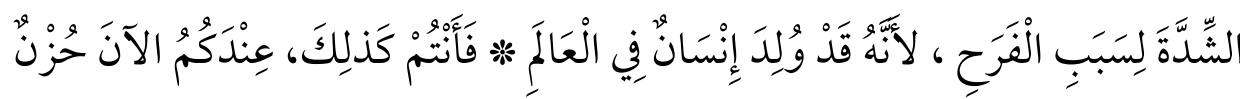

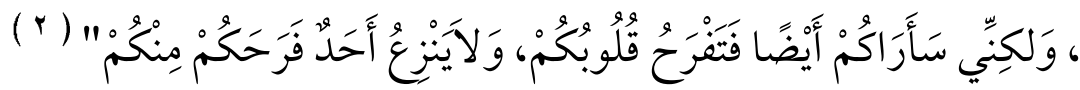

ومن أسباب ودواعي حزن المرء في النصر انية، الخطية يقول لوقا (r ) :" وَيْلُ

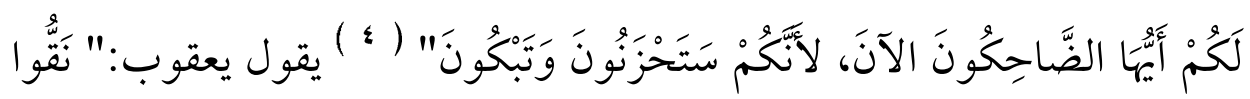

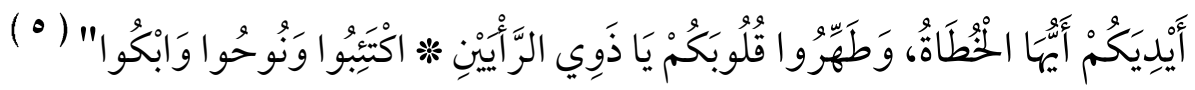
وهو - أيضًا - طريق إلى التوبة والرجوع إلى الله، جاء في رسالة بولس ( ')

$$
\begin{aligned}
& \text { سفر إشعياء، } 77 / 11 .
\end{aligned}
$$

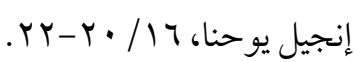

لوقا: ولد في أنطاكية ودرس الطب ومارسه بنجاح ورافق بولس في أسفاره وشاركه في أعماله، وهو كاتب سفر أعمال الرسل، وقتل في حكم "نيرون" سنة سبعين وكتب إنجيله

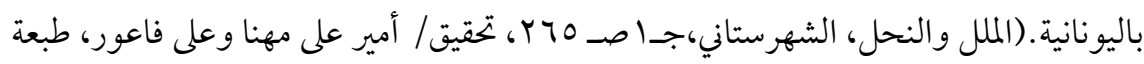

$$
\begin{aligned}
& \text { سنة إY ( اهـ- ( + . rم، دار المعرفة، بيروت - لبنان ) }
\end{aligned}
$$

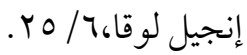

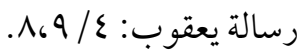

اسمه العبري:" شاول أو شاؤول" ومعناه في العربية والآرامية: سائل، وفى العبرية: المطلوب أو المرغوب فيه، واسمه الروماني: بولس وهو يعنى في الأوساط الرومانية: الصغير أو الأصغر $=$ 


\section{Ce. 잉}

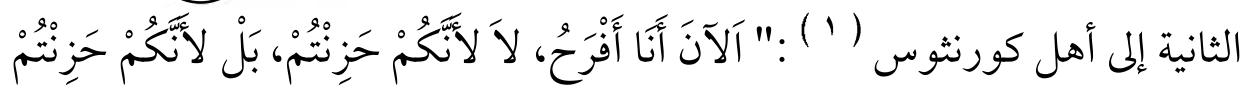

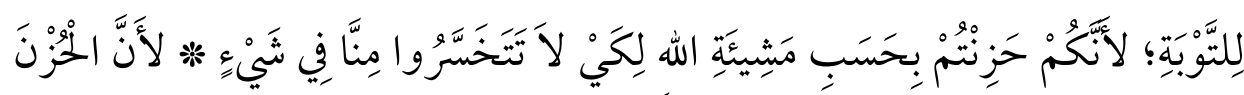

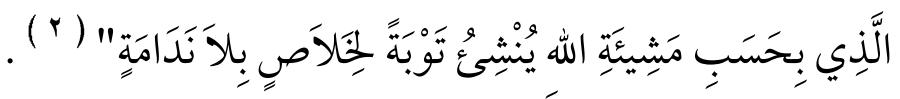
ويعلق القمص" تادرس يعقوب ملطي" على هذا النص فيقول: هنا يميز بولس بين نوعين من الحزن :

الأول : حزن حسب مشيئة اللَّ، حزن بسبب كسر للو صية الإلهية، هذا الحزن المقدس هو من أجل التمتع ببهجة الخلاص، فلا يستريح الإنسان التائب حتى ييد بمعنى: قليل الشأن أو الحقير، ولد في" طرسوس" - التابعة لولاية "كيليكية" من أعال

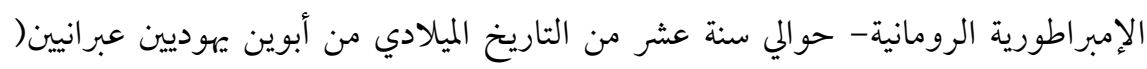

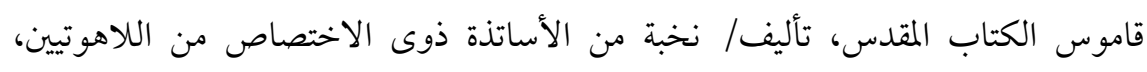

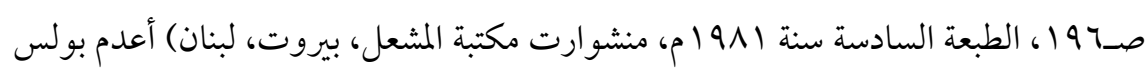

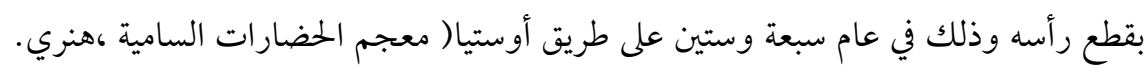

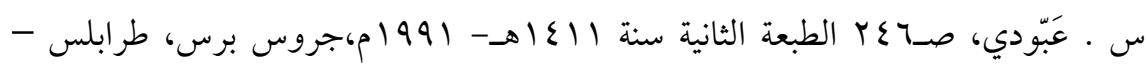

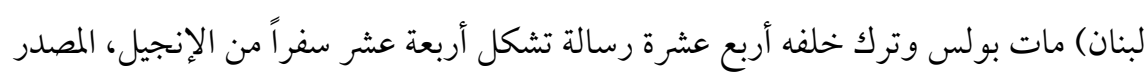

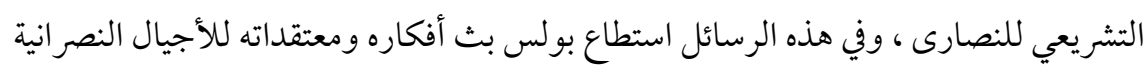
المثعاقبة.

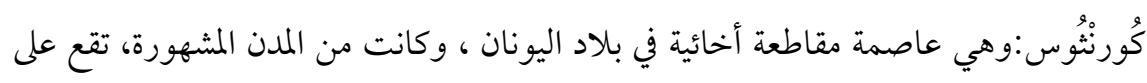

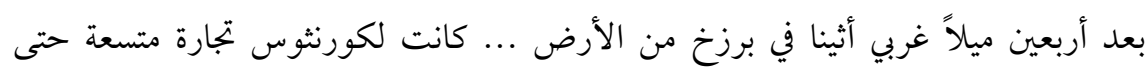

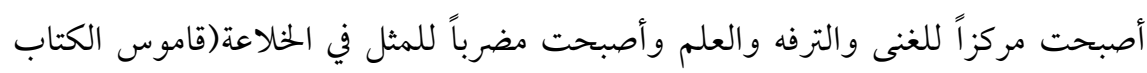

$$
\text { (المقدس، صـVAV) }
$$

الرسالة الثانية إلى أهل كورنثوس، 9/V، • 1 1. 
موضعًا في الأحضان الإلهية، فيرتفع قلب التائب إلى السماء.

الثاني: حزن العالم الذي يقوم على فقدان بعض أمور العالم المادية أو المعنوية،

سو اء كانت متلكات أو حقوق زمنية أو كرامة أرضية، هذا الحزن يحطم النفس .

هنا يقدم الرسول مفهومًا إنجيليًا رائعًا للحزن حسب مشيئة اللهَّ، فإنه يدفع

إلى التوبة بمعنى الرجوع إلى أحضان اللَّ لا اليأس، ويولد إصلاحًا وتجديدًا

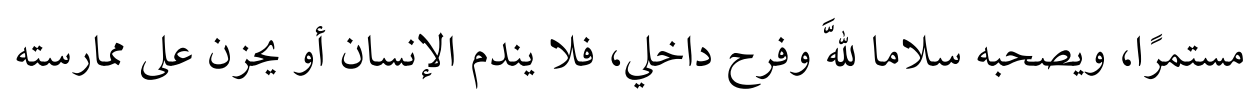

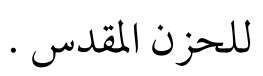

نوعين إذًا من الحزن الواحد: حزن العالم والآخر حزن حسب مشيئة اللهَّة

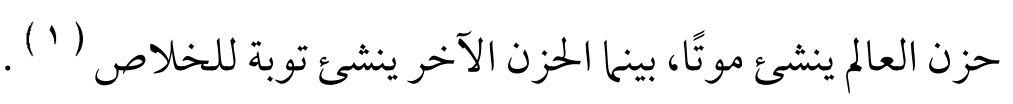

ولقد كان لهذه التعاليم أثرًا بالغًا في ترسيخ الشعور بالحزن عند اليهود

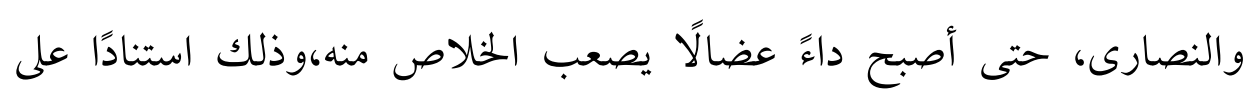

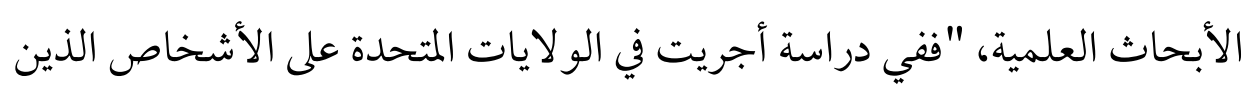

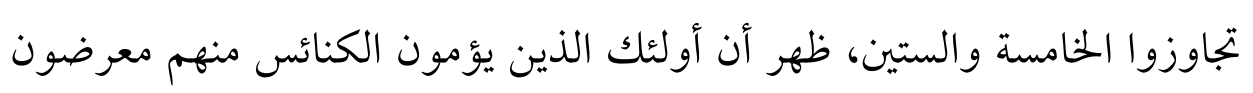
للإصابة بالاكتئاب بنسبة خمسين بالمائة أقل من نظرائهم الذين لا يذهبون إلى

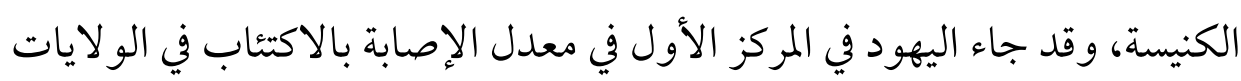
المتحدة، وتلاهم مباشرة النصارى الكاثوليك، أما نسبة الإصابة بين الذكور شرح الكتاب المقدس - العهد الجديد - القمص تادرس يعقوب ملطي، - http:/st takla.org 


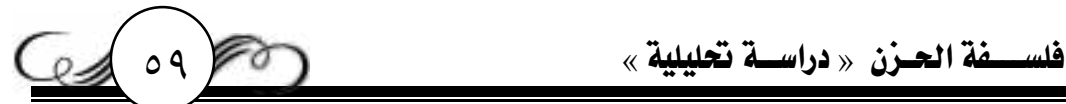

والإناث من اليهود في الولايات المتحدة، فكانت متساوية تقريبًا" ( 1 ). * أما الشيعة فمن بدعهم يوم عاشوراء" الحزن الشديد البالغ درجة ضرب الخدود وشج الرؤوس وإراقة الدماء؛ لمقتل الإمام الحسين بن علىِ - رضي الله عنها- وهذا الشكل من الأحزان محرم في الإسلام، ومحدث لا أصل له، وهو من ثقافاتهم الخاصة، وتعاليم رؤساؤهم الضالين المضلين، الذين حفزوهم بأحاديث اختلقوها لا أصل ها، كحديث:" الْبكاء يَوْم عَاشُورَاء نور تَامّ يَوْم الْقِيَامَة"

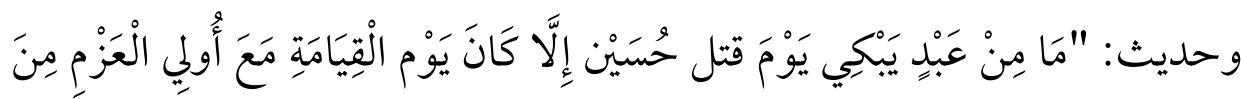

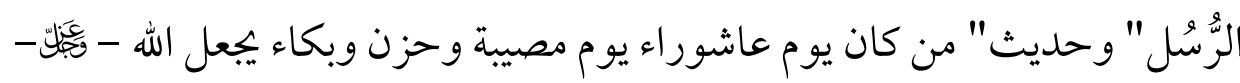
يوم القيامة يوم فرحه وسروره" (r ) وجاء في كتب الشيعة الوصية باجتناب الملاذ فيه وإقامة سنن المصائب والإمساك عن الطعام والشراب إلى أن تزول الشمس، والتغذي بعد ذلك بها يتغذى به أصحاب المصائب كالألبان وما أشبهـا دون اللذيذ

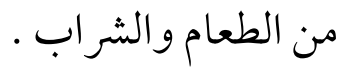

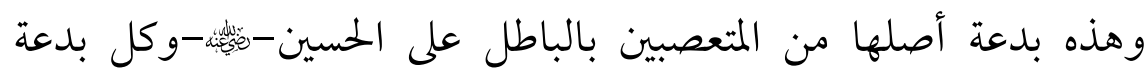
ضلالة، ولم يقل أحد من أئمة المسلمين بهذا الكلام، بل المستحب يوم عاشوراء:

$$
\text { الحزن الخبيث، لويس ولبرت، صـو11 } 11 \text {. }
$$

هذه الأحاديث موضوعه انظر الفوائد المجموعة في الأحاديث الموضوعة، محمد بن علي الشوكاني، صد·ع ع، تحقيق/عبد الرحمن بن يجي المعلمي اليهاني، دار الكتب العلمية، بيروت-

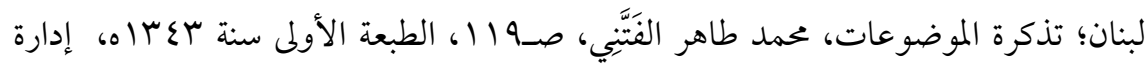

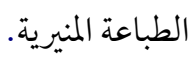




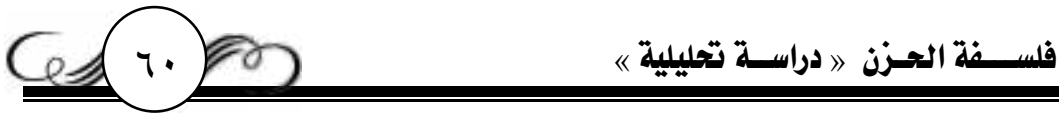

الصيام عند جمهور العلم|ء، لما رواه البخاري من حديث عبد الله بن عباس رضي الله

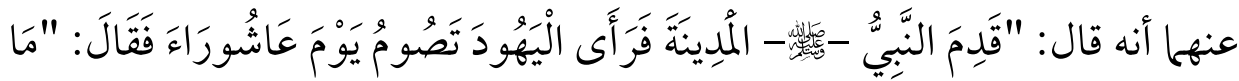

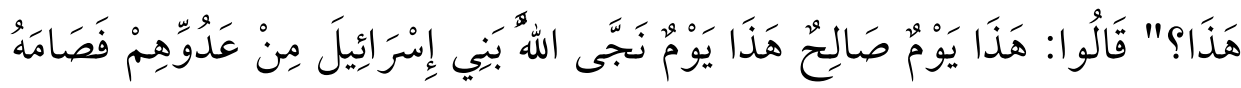

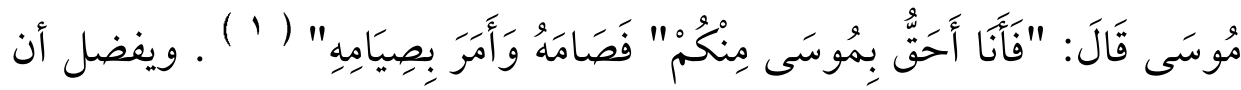

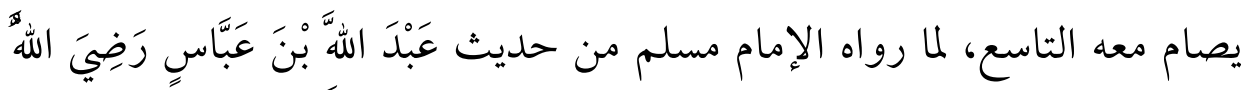

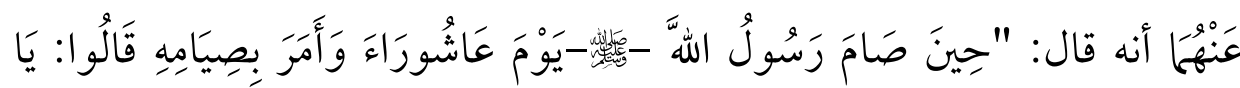

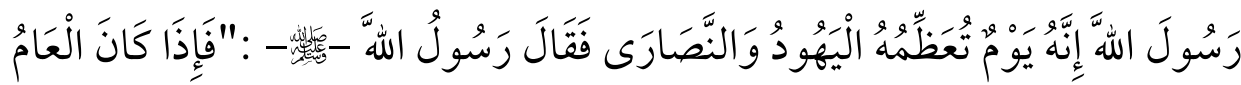

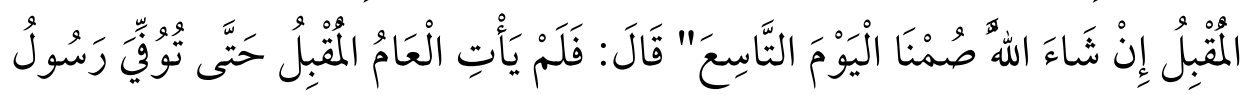

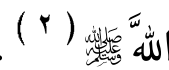

وفي زيارة الحسين يوم عاشوراء من قرب وبعد، قالوا: "لَْنْنُبِ - الزائر -

الْحُهَنْنَ ويَبْكِيه ويأمر من في دارهم من لا يتقيه بالبكاء عليه ويقيم في داره المصيبة بإظهار الجزع عليه وليعز بعضهم بعضًا بمصابهم بالحسين " ( ") . وردًا على هذا الكلام يقول ابن تيمية ( ؛ ) :"وصار الشيطان بسبب قتل

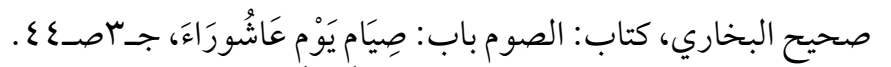

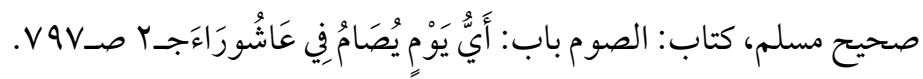

راجع باب: استحباب البكاء لقتل الحسين وما أصابه من كتاب: وسائل الشيعة(آل البيت) الحر العاملي، جــ اصـ. .0، تحقيق/مؤسسة آل البيت عليهم السلام لإحياء التراث، الطبعة الثانية

$$
\text { سنة إع ا هـ، مؤسسة آل البيت، قم- إيران. }
$$

أحمد بن عبد الحليم بن عبد السلام بن عبد الله بن أبى القاسم الخضر النميري الحراني الدمشقي 


\section{Geniin}

الحسين-مئهة- يحدث للناس بدعتين: بدعة الحزن والنوح يوم عاشوراء، من اللطم والصراخ والبكاء والعطش وإنشاد المراثي، وما يفضي إليه ذلك من سب السلف بدرك

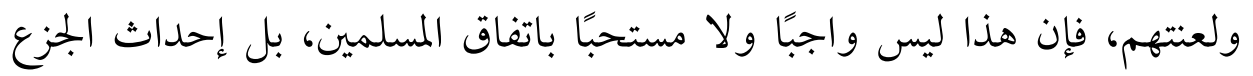
والنياحة للمصائب القديمة، من أعظم ما حرمه الله ورسوله" ( ' ) .

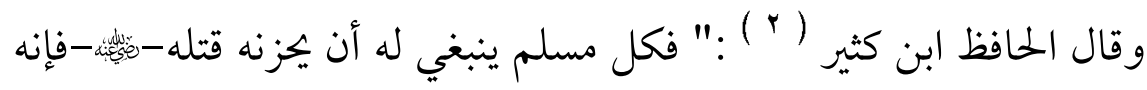

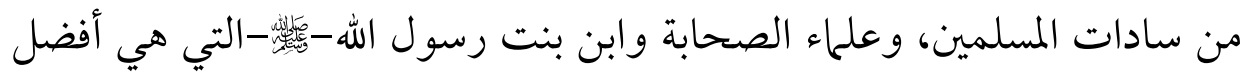
بناته، وقد كان عابدًا وشجاعًا وسخيًا، ولكنه لا يَُُّْْ ما يفعله الشيعة من إظهار

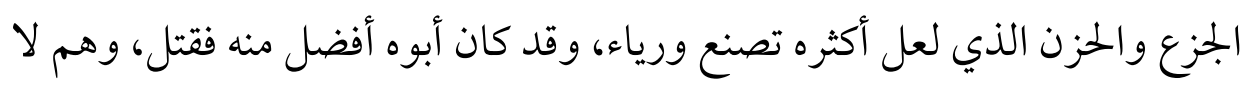
يتخذون مقتله مأتمًا كيوم مقتل الحسين، وكذلك عثمان كان أفضل من علي عند أهل

الحنبل، تقي الدين ابن تيمية، شيخ الإسلام، ولد سنة إحدى وستين وستائة من الهجرة، في

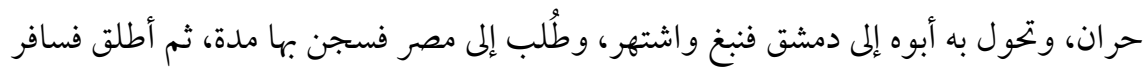

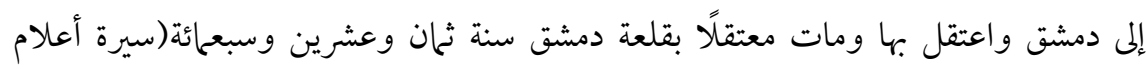

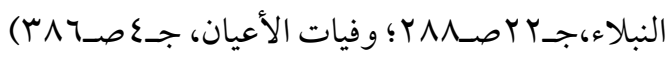

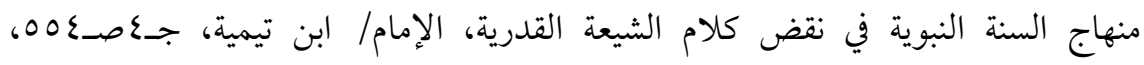

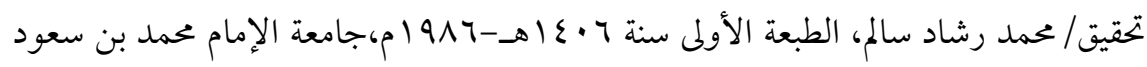
الإسلامية، المملكة العربية السعودية. إساعيل بن عمر بن ضوبن درع القرشي البصروى ثم الدمشقي، أبو الفداء، عاد الدين الحافظ

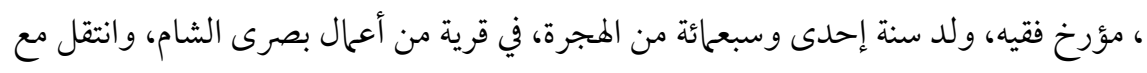

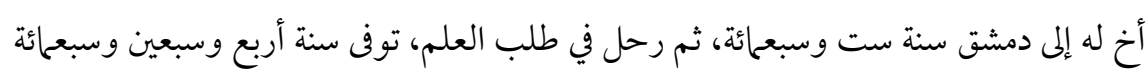

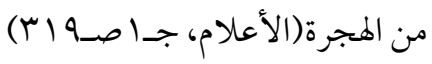




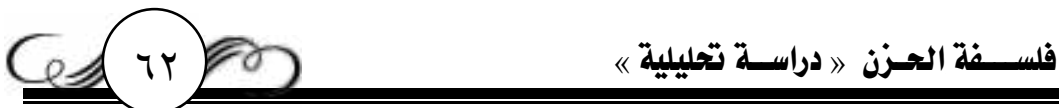

السنة والجماعة، ولم يتخذ الناس يوم قتله مأتمًا، وكذلك عمر بن الخطاب وهو أفضل من عثمان وعلي، ولم يتخذ الناس يوم مقتله مأتمًا، وكذلك الصديق كان

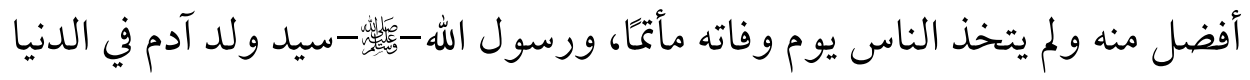
والآخرة، وقد قبضه الله إليه كما مات الأنبياء قبله، ولم يتخذ أحد يوم موتهم مأتمًا، يفعلون فيه ما يفعله هؤ لاء الجهلة من الر افضة يوم مصرع الحسين" ( 1 ).

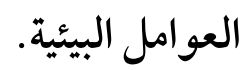

ونقصد بالعوامل البيئية الاضطرابات العاطفية أو الانفعال والحزن الموسمي، وهذا النوع يصاب به بعض الأفراد نتيجة تغير فصول السنة، وتتبعها، ومن أكثر أنواعه شيوعًا "الحزن الشتائي"، وسببه: قصور النهار، وطول الليل، مما تتغير معه كمية ضوء الشمس، فتبدأ الأعر اض في الظهور، و أشدها: اعتلال المزاج، وفقدان القدرة على الاستمتاع، والشعور بالنصب و التعب الشديدين. وعلاقة ضوء الشمس بالحالة النفسية والمزاجية، أن هرمون " السيروتونين" هو أحد المواد الكييائية والنواقل العصبية الهامة الموجودة في الدماغ، والتي تقوم وتتولى أمر تحسين المزاج، ومنع الشعور بالإحباط والاكتئاب، وضوء الشمس من الوسائل الطبيعية التي تزيد من معدلات هذا الهرمون عن طريق تحفيزه للغدة الصنوبرية المسئولة عن تنظيم إفراز الهرمونات.

( ) البداية والنهاية، الإمام/ابن كثير، جـيصـابY،، تحقيق/ علي شيري، الطبعة الأولى سنة

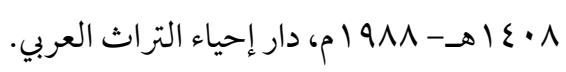




\section{Ge $\pi$}

ولقد عُرف هذا النوع من الحزن منذ زمن بعيد قد يعود إلى "أبقراط" عام

أربعمائة قبل الميلاد، وقد عالج الأطباء الإغريق والرمان المصابين بهذا الداء عن

طريق تعريض عيني المريض لضوء الشمس المباشر ( ')

أما في العصر الحاضر فيقول "لويس ولبرت ( r ) " الذي درس هذه

الظاهرة وعاشها:" تنبع أهمية غياب ضوء الشمس وارتباطه بالاكتئاب الموسمي

من انتشار الاضطراب الانفعالي الموسمي (SAD) بصورة واضحة في النصف الشمالي من الكرة الأرضية حيث تزداد الأعراض وضوحًا كلما قصرت فترة النهار، وطالت مدة الليل في تلك المناطق، كما تظهر الأعراض ذاتها عند أولئك الذين يعملون في المناطق الشمالية داخل غرف لا يدخلها ضوء الشمس" (" ) وعلى الرغم من أن هذه الحالة تحدث عادة في فصلي الخريف والشتاء إلا أن هناك من يعاني من هذه الحالة خلال فصل الصيف.

$$
\text { الحزن الخبيث، لويس ولبرت، صـr I I ا. }
$$

ولد لويس ولبرت في جنوب إفريقيا، وتلقى تعليمه في جامعة إمبيدريال كوليج في لندن،

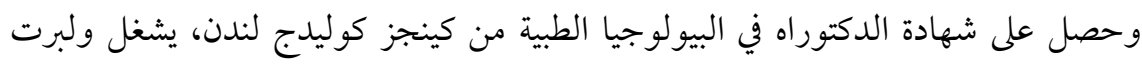

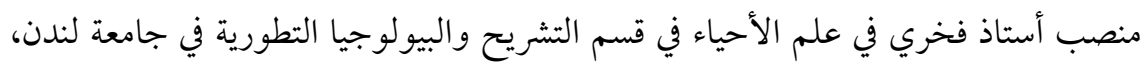
وتنصب اهتماته البحثية على دراسة تطور الأجنة، ويرأس عدة جمعيات علمية وإنسانية،

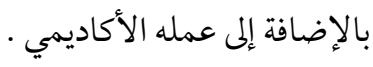

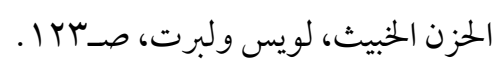




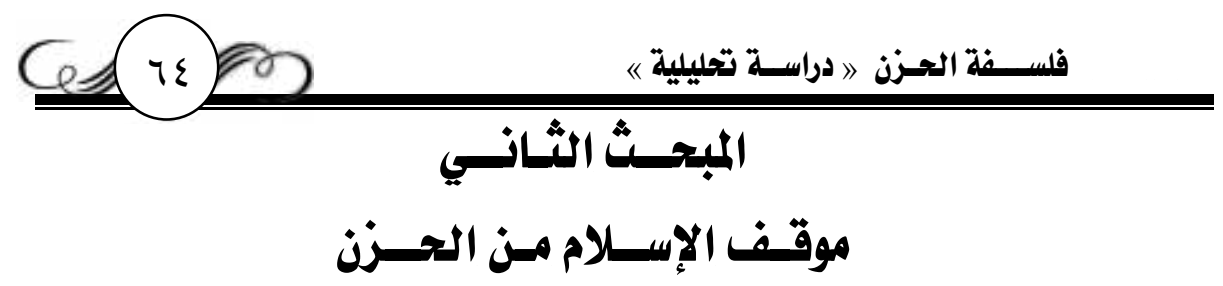

لم يأت الحزن في القرآن الكريم إلا منهيًا عنه أو منفيًا، فالمنهي عنه كقوله تعالى

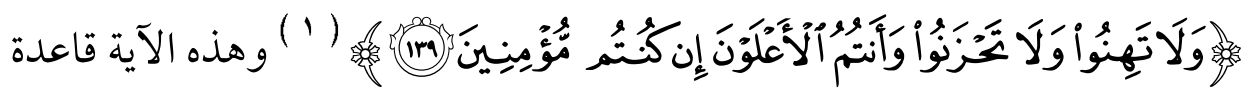

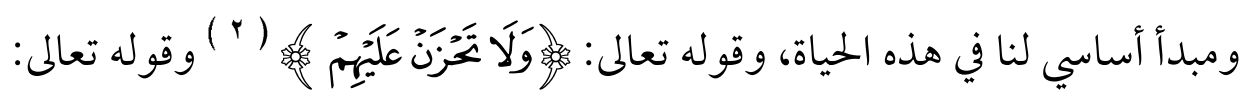

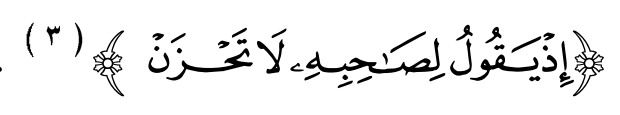

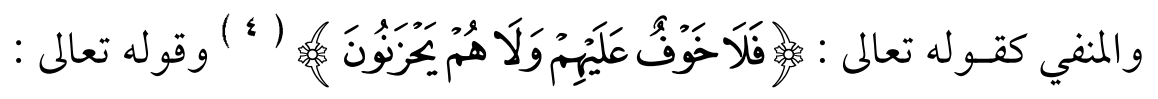
مارَ

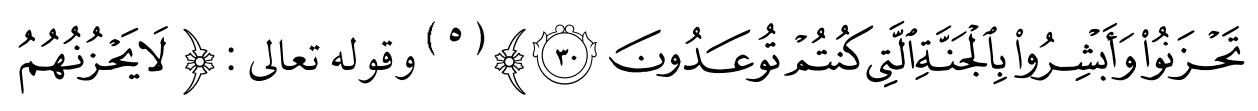

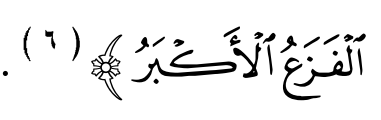

يقول العلامة ابن القيم ( v ) : " اعلم أن الحزن من عوارض الطريق، ليس

$$
\begin{aligned}
& \text { (') سورة آل عمران، الآية:9 إ. }
\end{aligned}
$$

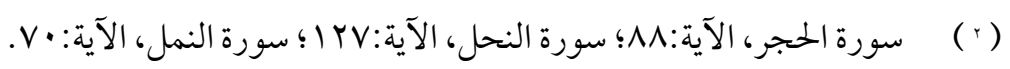

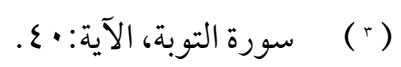

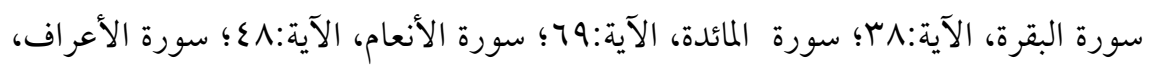

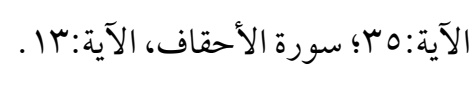

$$
\begin{aligned}
& \text { (•) سورة فصلت، الآية:•r. }
\end{aligned}
$$

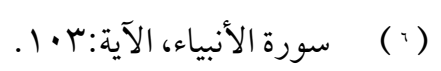

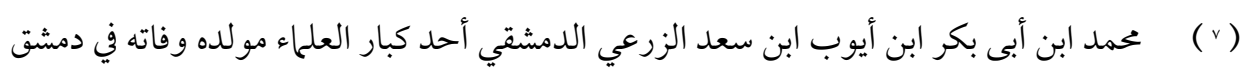
$=$ 


\section{Ge 10}

من مقامات الإيمان، ولا من منازل السائرين؛ ولهذا لم يأمر الله به في موضع قط ولا أثنى عليه، ولا رتب عليه جزاءُ ولا ثوابًا بل نهى عنه في غير موضع" ( ' ) . ويقول شيخ الإسلام ابن تيمية : "وأما الحزن فلم يأمر الله به ولا رسوله، بل قد نهى عنه في مو اضع وإن تعلق بأمر الدين... وذلك لأنه لا يجلب منفعة ولا يدفع

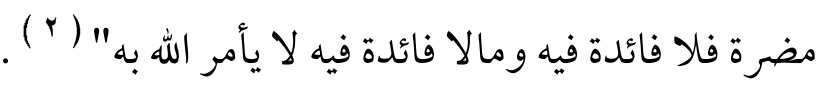
وهذا من أسباب الغرض القرآني لهذا العارض الغير مرغوب فيه، بالإضافة إلى ما سبق، فإنه لا مصلحة فيه للقلب، فهو يضعفه، ولا شيء أحب إلى الشيطان

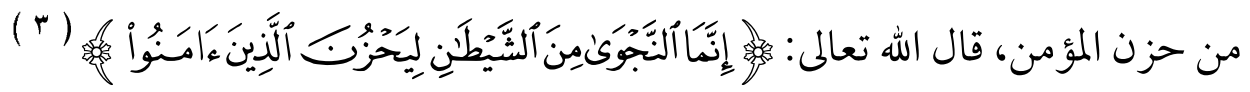

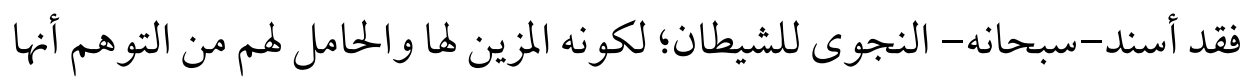
في مكيدة يكادون بها، أو أن وراء هذه النجوى أخبار سيئة تتعلق بهه أو بذويهم. على أن الشيطان ينتهز تلك الخفقة فرصة يكون فيها أملك على إفساد المؤمنين، وإخراجهم من طاعة الله إلى معصيته، إذ أن من محصلة الحزن: فقدان

تتلمذ لشيخ الإسلام ابن تيمية وهو الذي هذب كتبه ونشر علمه، وسجن معه في قلعة دمشق، وأهين وعذب بسببه، وأطلق بعد موت ابن تيمية، وكان حسن الخلق محبوبًا عند الناس وله

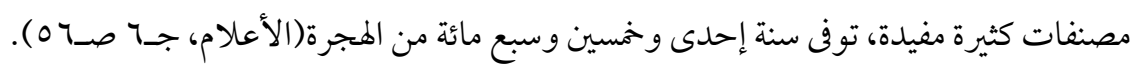

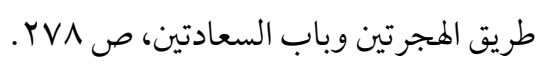

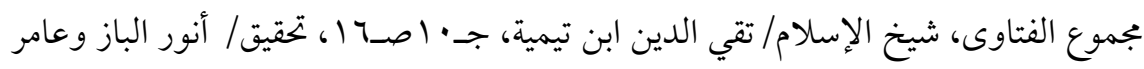

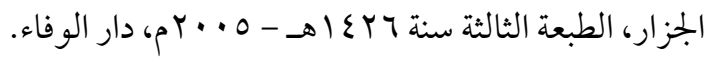




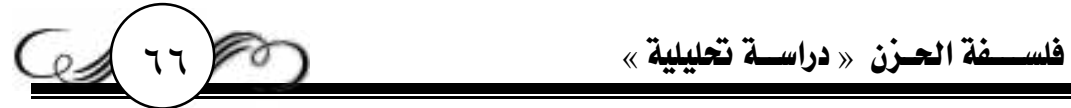

التفكير، وتعطيل آلة الإدراك، ليصبح الإنسان في تلك الحالة فريسة سائغة لمخالب الشيطان ووساوسه، قصدها وظفر بها.

يمكن أن نقول: إن الإسلام ينهي عن المداومة على الحزن وما يلازمه لأسباب التالية :

1 - لأنه يضعف القلب، ويوهن العزم، ويخزل الإرادة، وبهذه العوارض يصبح مرضًا من أمر اض القلوب، يمنعه من النهوض و السير على طريق الجدة. r - الحزن مدخل من مداخل الشيطان الذي يصيب الإنسان بالحزن ليحبطه فيقعد عن عمل الصالحات، ويصبح ممهدًا لتلقي الهواجس والخطرات الشيطانية وبعدها يصبح المرء صريع الهموم والأحزان.

ب - ينهي الإسلام عن المداومة على الحزن؛ لأنه ليس فيه منفعة للإنسان، وما لا فائدة فيه لا يأمر الله به .

أما ما ورد من نصوص توهم التعارض، وتدل على أن الحزن مقام ينبغي

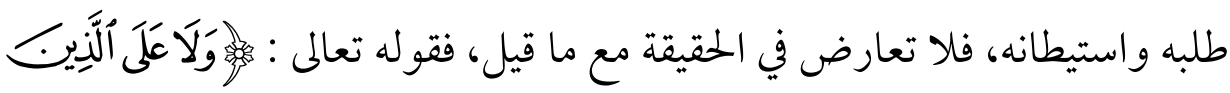

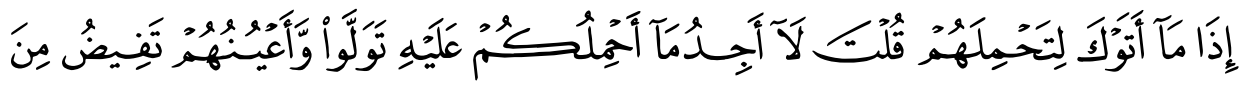

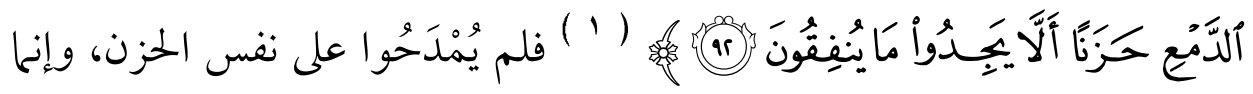
مُدِحُوا على ما دل عليه الحزن من قوة إيهانهم، حيث تخلفو اعن رسول الله - - 


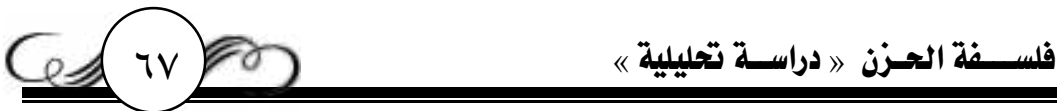

لعجزهم عن النفقة، فقيه تعريض بالمنافقين الذين لمُ يحزنوا على تخلفهم، بل غَبَطُوا

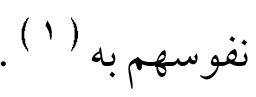

والإمام ابن تيمية يرى أن الحزن لا يحمد لذاته، وإنما يحمد لسببه ومصدره

ولا زمه، فهو يقول :" قد يقترن بالحزن ما يثاب صاحبه ويحمد عليه، فيكون محمودًا

من تلك الجهة لا من جهة الحزن، كالحزين على مصيبة في دينه، وعلى مصائب المسلمين عمومًا، فهذا يثاب على ما في قلبه من حب الخير، وبغض الشر، وتوابع ذلك، ولكن الحزن على ذلك إذا أفضى إلى ترك مأمور من الصبر والجهاد، وجلب منفعة، ودفع مضرة، كان مذمومًا من تلك الجهةة" (r ) .

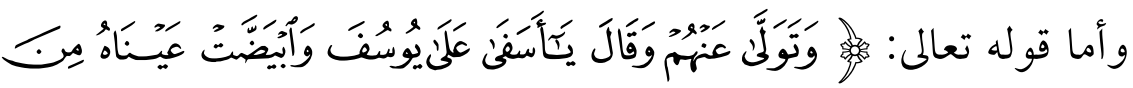

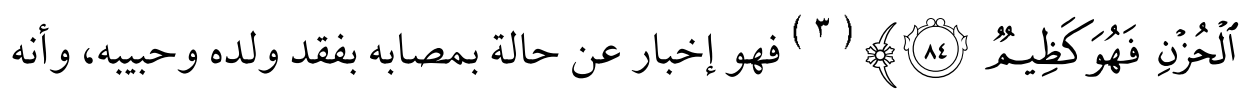
ابتلاه بذلك كما ابتلاه بالتفريق بينه وبينه .

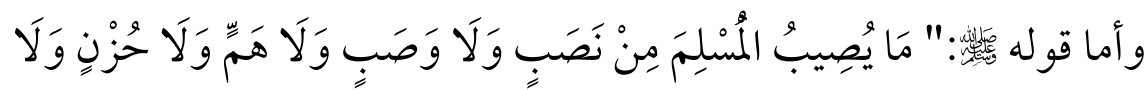

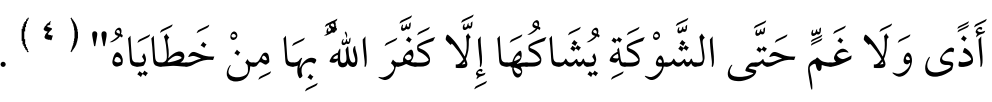

$$
\text { مدارج السالكين بين منازل إياك نعبد وإياك نستعين، صـا - } 0 .
$$

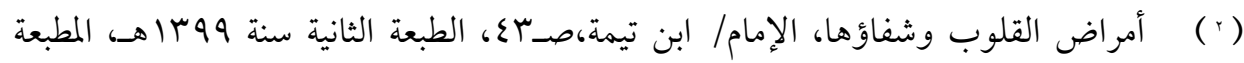

$$
\text { السلفية، القاهرة. }
$$

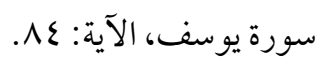

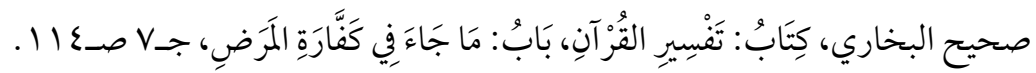




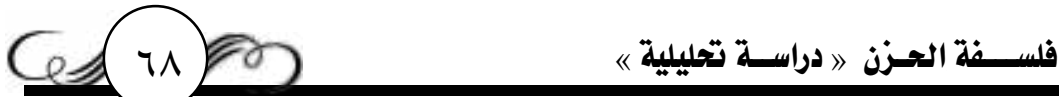

فهذا يدل على أنه مصيبة من الله يصيب بها العبد، يكفر بها من سيئاته لا لكونه مرغوب فيه ومطلوب، ويعد الحزن- أيضًا- مرضًا من أمراض الباطن "أمراض النفس" ولذلك ساغ عطفها على الوصب وهو المرض.

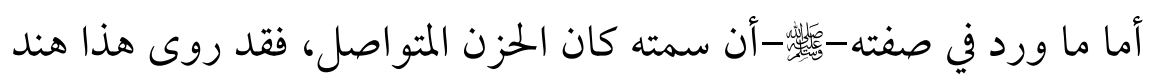

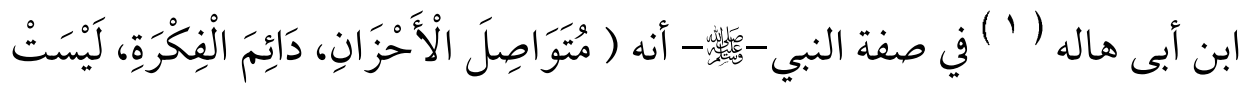

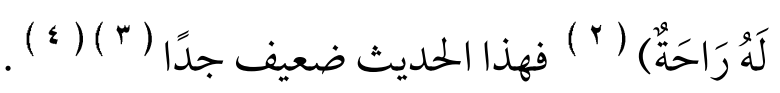

وحاله-

الله - تعالى -في الدنيـا وعليهـا ، ونهـاه عن الحـزن على المشــــين والمنحــرفين عن

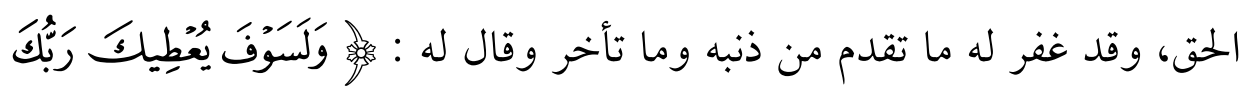

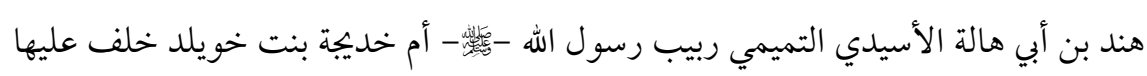

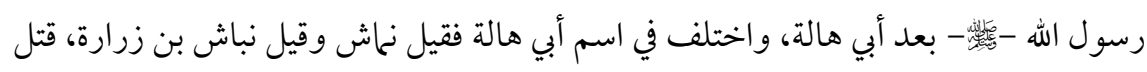

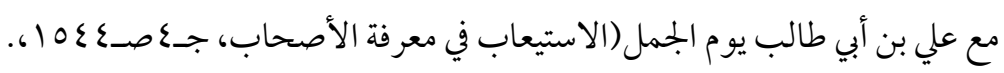

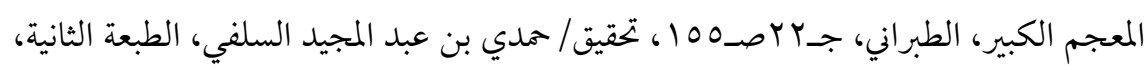

$$
\text { مكتبة ابن تيمية - القاهرة. }
$$

غختصر الشمائل المحمدية، الترمذي،صـ/ ا-•ب، تحقيق/محمد ناصر الدين الألباني، المكتبة

$$
\text { الإسلامية، عمان-الأردن. }
$$

وله علتان: الأولى: جهالة أبي عبد الله التميمي، قال الحافظ وغيره: "ججهول" الثانية: ضعف جميع بن عمير هذا، واتهمه بعضهم(انظر سلسلة الأحاديث الصحيحة وشيء من فقهها

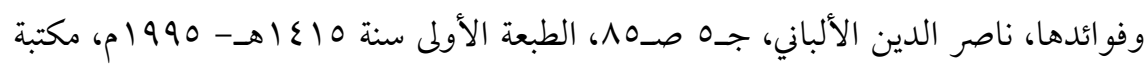

$$
\text { المعارف، الرياض) }
$$




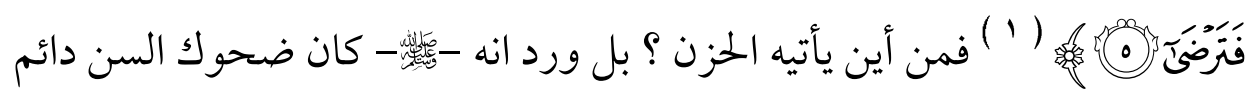
البشر، فهذه كلها آثار وأخبار لا يعول عليها في هذه القضية .

ومع هذا نريد ننوه إلى أنه طالما كان الحزن من عوارض الطبيعة البشرية

وانفعال من الانفعالات اللازمة للإنسان فإن الشرع الحنيف لا ينهى عنه نهى تحريم؛ لأنه خارج عن سلطان المرء، والشرع لا يكلف مالا يطاق، فلا يكون محرمًا ما دام مقتضاه صحيحًا، وبالنظر إلى المقتضى وجدنا أن النصوص التي جاءت في

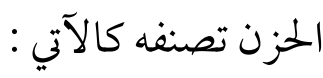

أولًا : إذا أمعنا الفكر في حال الفقراء الذين لم يجدوا النفقة والر احلة، ليبلغوا

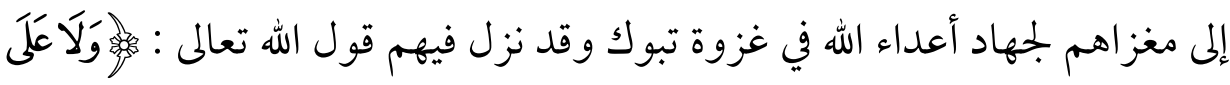

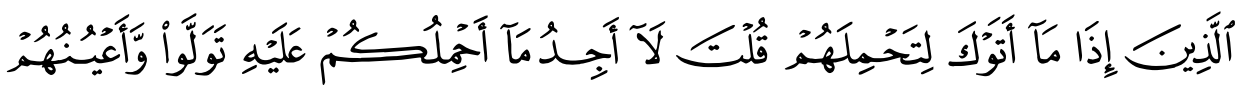

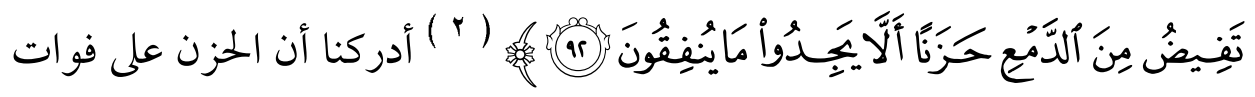
الطاعة من باب المستحبات التي تدل على إيانيات المرء،وإخلاصه، ورقة قلبة،

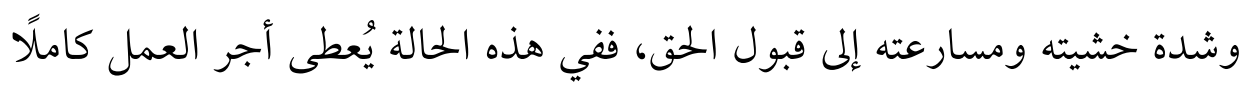

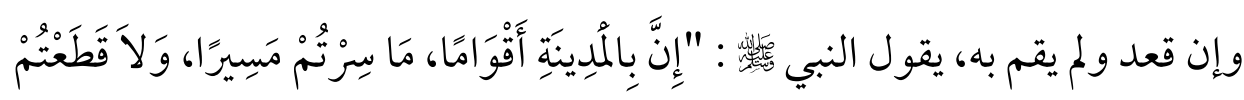

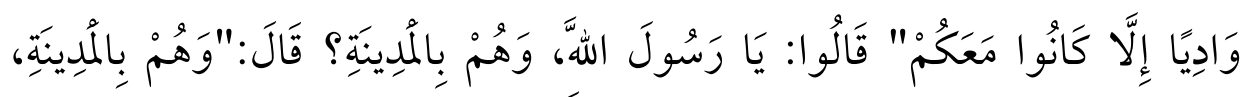

سورة الضحى، الآية:0. 


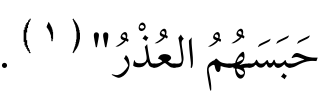

من هذا الضرب - أيضًا- الحزن على فعل المعصية، وهو شرطُ من شروط

التوبة النصوح، والمتمثّل في الندم على فعل المعصية، والندم يعنى : الحسرة والحزن على ما فات، وما مضى من الذنوب، هذه الحسرة، وتلك الحزن، هما الركن الأساسيّ

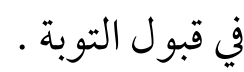

يقول الإمام الغزالي ( r ) : " التوبة عبارة عن ندم حتى جاء في الحديث:"

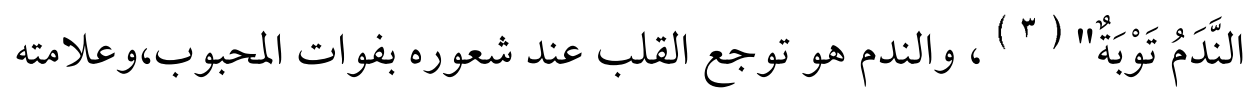
طول الحسرة والحزن، وانسكاب الدمع وطول البكاء، على نزول العقوبة من

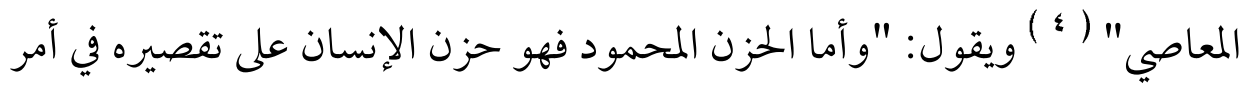

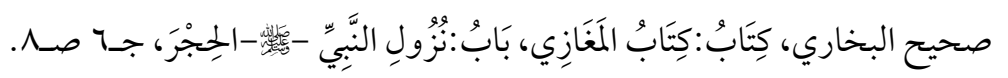

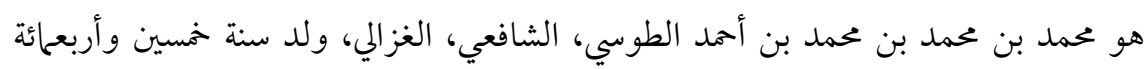

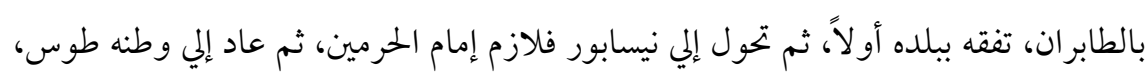
وصنف الكتب المفيدة في عدة فنون، وتفرغ من التصنيف سنة ثلاث وخمسمائة، توفي سنة خمس

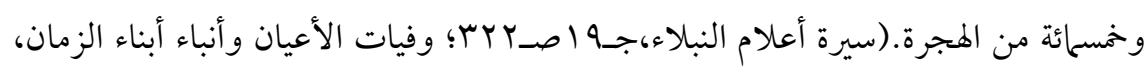

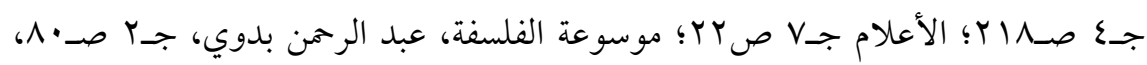

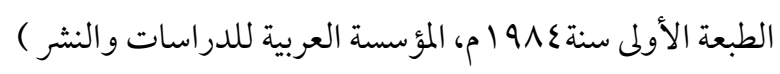

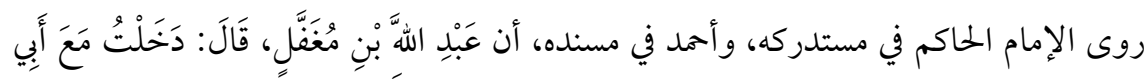

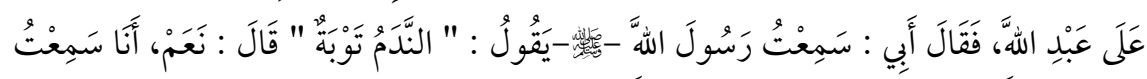

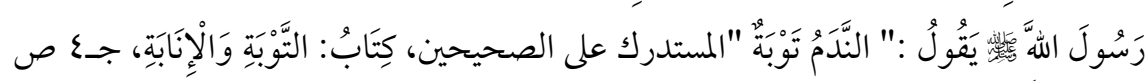

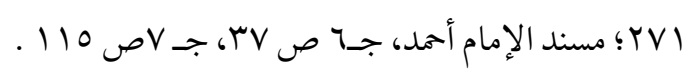

انظر إحياء علوم الدين، الإمام/ أبو حامد الغزالي، جـعـعـا، دار المعرفة، بيروت- لبنان. 


\section{Gen}

دينه، وبكاؤه على خطاياه، والبكاء والتباكي، والحزن والتحازن على ذلك محمود، وتحريك هذا الحزن وتقويته مطلوب؛ لأنه يبعث على التشمير للتدارك ولذلك

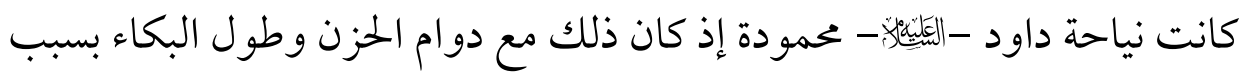

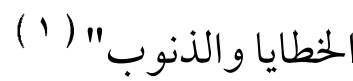

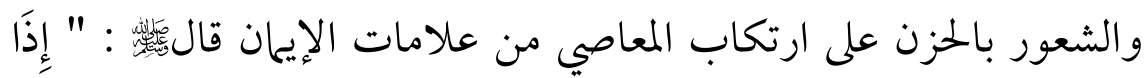

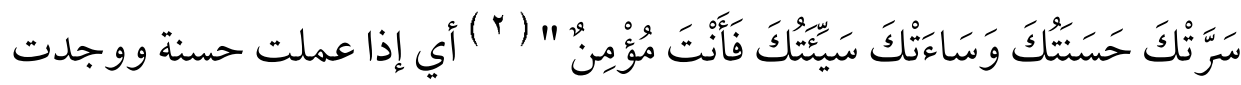
حلاوتها في قلبك فقرحت وسررت بتوفيق الطاعة، وإذا فعلت سيئة ووقع في قلبك حزن ومساءة فأنت مؤمن، فإن المؤمن الحق الموقن بالثواب والعقاب، يميز بين

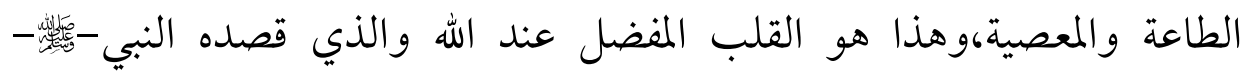

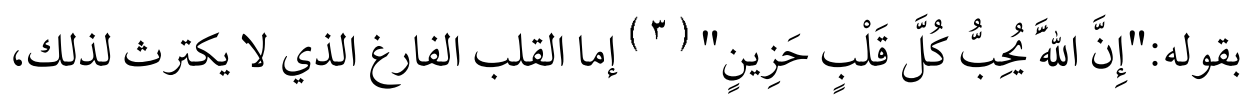
فيقول عنه مالك بن دينار ( ؛ ) : " إن القلب إن لم يكن فيه حزن خرب، كما أن

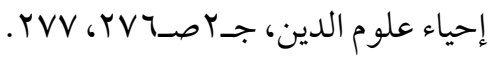

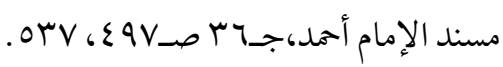

رواه الإمام الحاكم، وقال صحيح الإسناد ولم يخرجاه، المستدرك على الصحيحين،كِتَابُ:

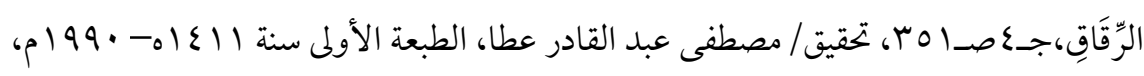

$$
\text { دار الكتب العلمية، بيروت-لبنان. }
$$

مالك بن دينار مولى لبنى ناجية بن سامة بن لؤي بن غالب القرشي أبويميى، من زهاد التابعين

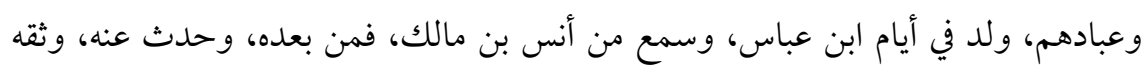

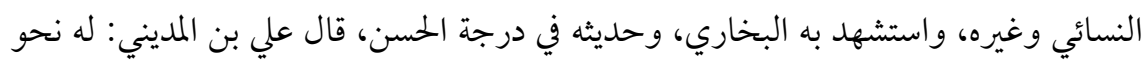

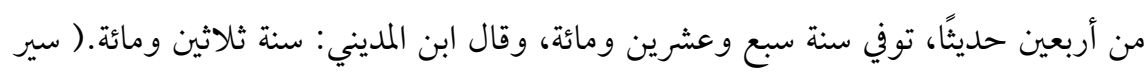

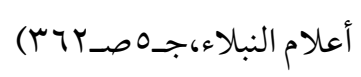




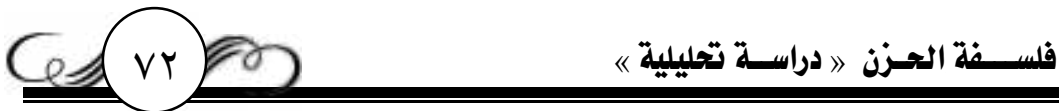

البيت إذا لم يسكن خرب " ( 1 ) فالقلب إذا لم يساكنه حزن على فوات الطاعة، وحزن على اقتراف معصية، وفوات أمر من أمور الخير، فإن ذلك القلب يكون خربًا

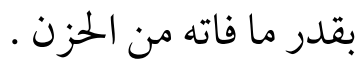

ثانيًا : الحزن المشروع : وهو ما كان بدمع العين، ورقة النفس، ولم يكن تسخطًا لأمر الله تعالى، إذ الفطرة بجبولة على الحزن عند فقد عزيز، وغياب حبيب، ولنا في رسول الله - الصالحة، فالنبي-

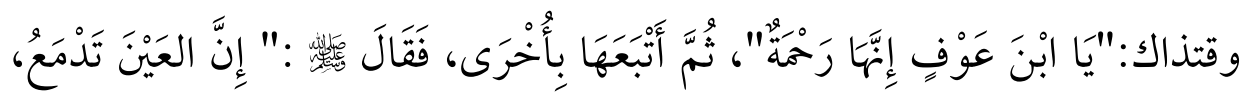

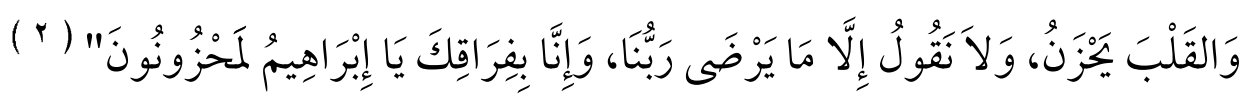

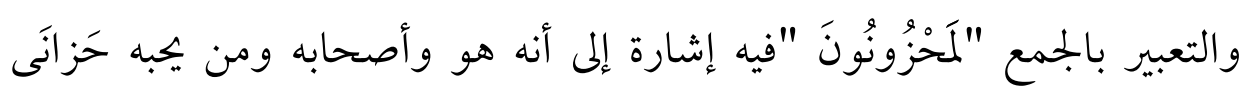
بحزنه،كا أنه عبر بصيغة المفعول لا بصيغة الفاعل؛ ليد على أن الحزن واقع بهم من غيرهم، وليس من فعلهم، ولا يكلف الإنسان بفعل غيره.

وقوله الحزن، رحمة جعلها الله في قلوب عباده تنبعث عن التأمل فيا هو عليه، لا ما توهمه

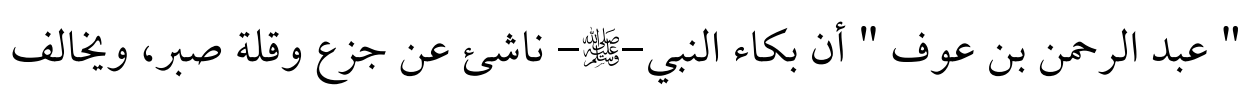

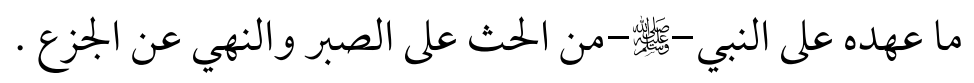

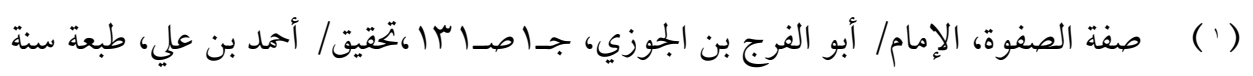

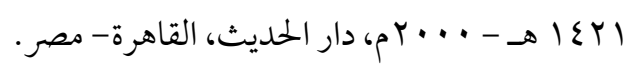

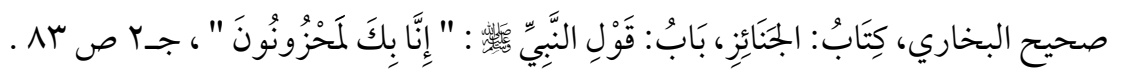




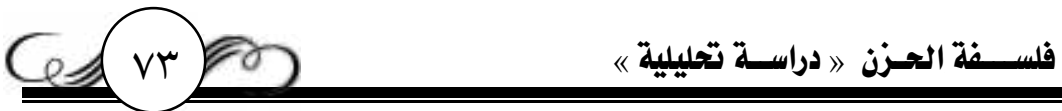

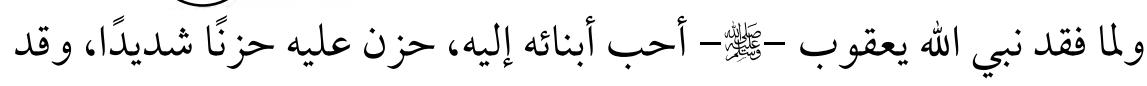

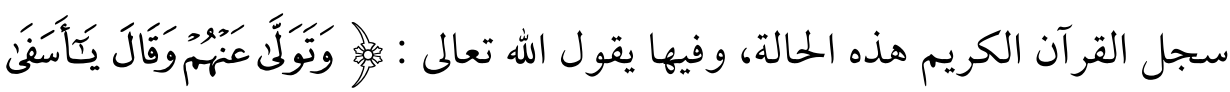

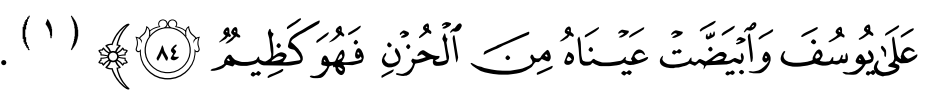
فالحزن على الفقيد وفاءً له، ورقة عليه، مباح لا شيء فيع، مالم يكن سخطًا

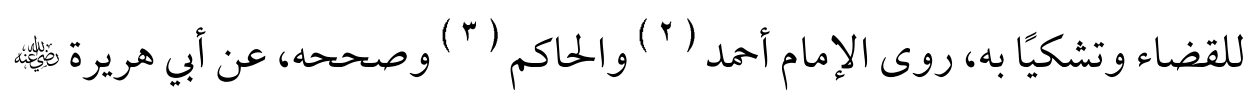

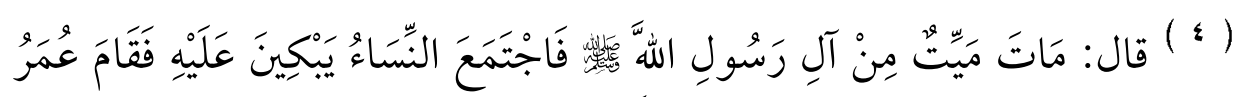

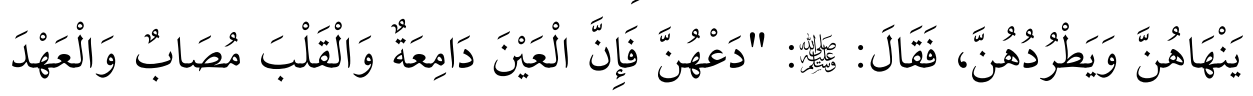

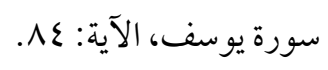

هو أحمد بن حنبل، أبو عبد الله الشيباني المروزي ثم البغدادي قدم به أبوه من مرو مدينة بخرسان

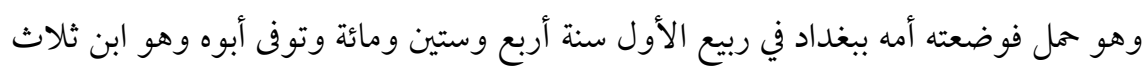
سنين فكفلته أمه توفى سنة إحدى وأربعين ومائتين وله من العمر سبع وسبعون سنة رحمة الله

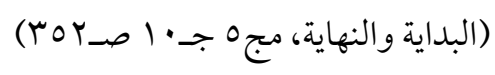

الحاكم بن البيع النيسابوري، أبو عبداله حممد بن عبد الله بن محمد بن حمر اويه بن نعيم بن الحكم

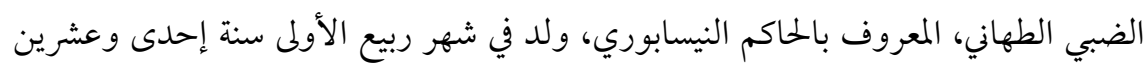

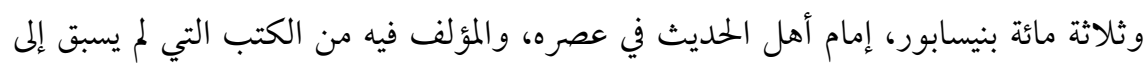

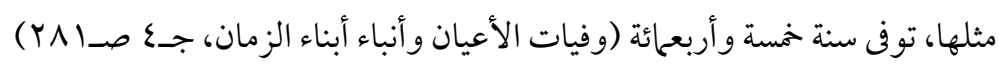
عبد الرحمن بن صخر الدوسي الياني، ولد سنة إحدى وعشرين قبل الهجرة يتيًًا ضعيفًا في

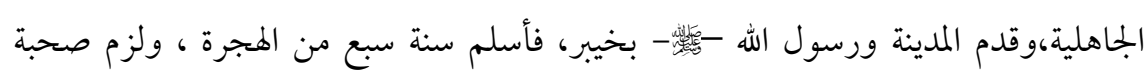
النبي-

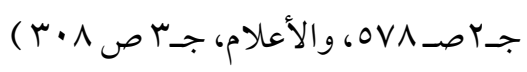




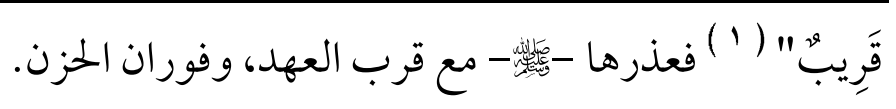

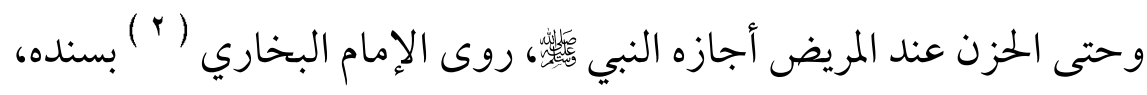

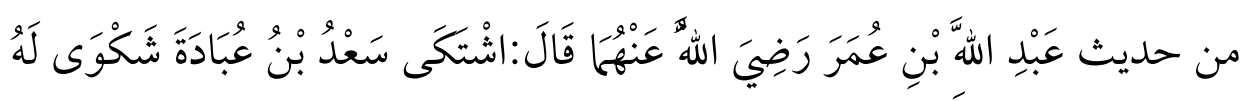

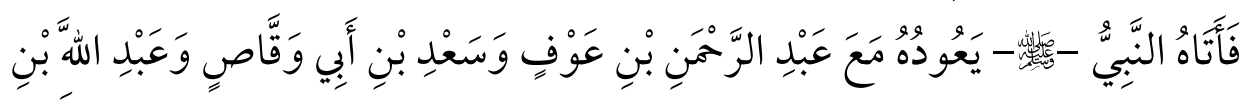

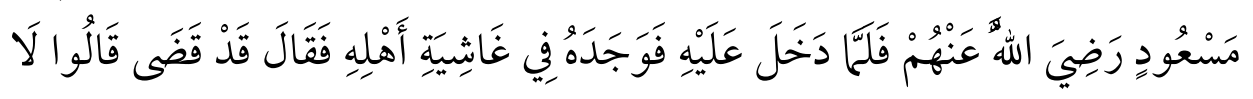

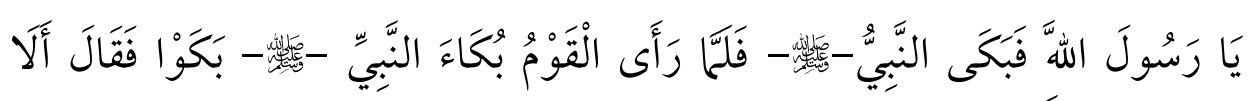

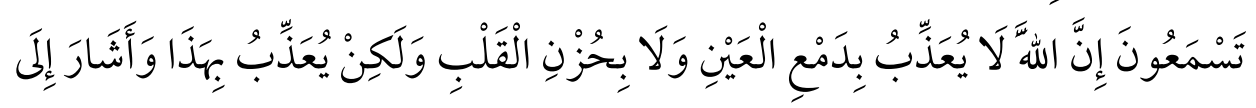

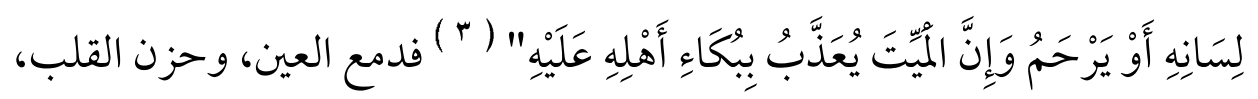
لا ينافيان الرضا بالقضاء القدر، فها من خلق الله، كما خلق الموت والحياة، قال الله

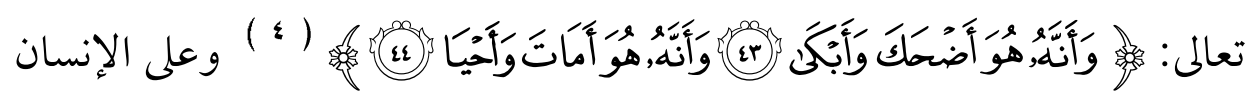
العمل لدفع أسباب هذا الحزن، والتدرع والشكوى إلى الله-تَّيَلْه - اقتضاءً بني الله

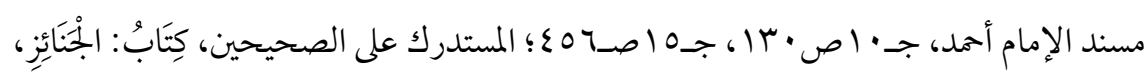

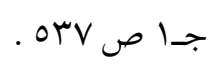

محمد بن إسماعيل بن إبراهيم بن المغيرة البخاري، ولد سنة أربع وتسعين ومائة من الهجرة في

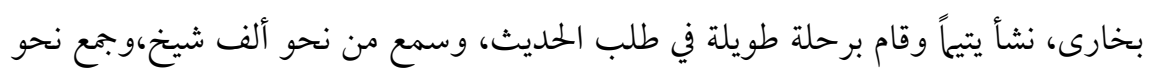
ستمائة ألف حديث، اختار منها في صحيحه ما وثق بروايته، سنة ست وخمسين ومائتين بخرتنك

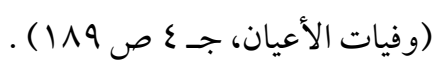

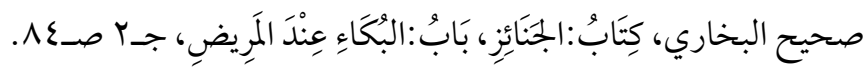

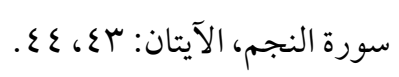




\section{Celvo}

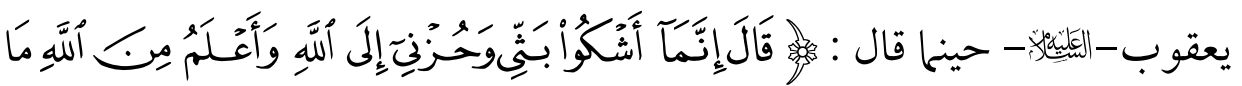

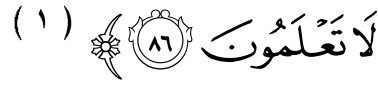

ثالثًا : الحزن المكروه، ويكون على فوات منفعة دنيوية، ومتعه من متاعها الفاني، التي لا يستحق التحسر عليه،يقول الإمام القشيري ( ( ) : "وتكلم الناس في الحزن فكلهم قالو ا: إنها يحمد حزن الآخرة، وأما حزن الدنيا فغير محمود" (r) وكيف يجزن المرء بعدما علم أن المقادير تجري بأمر الله، وهي سابقة قد جف

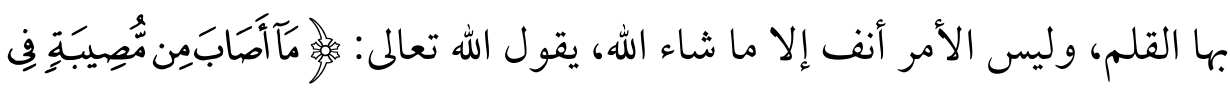

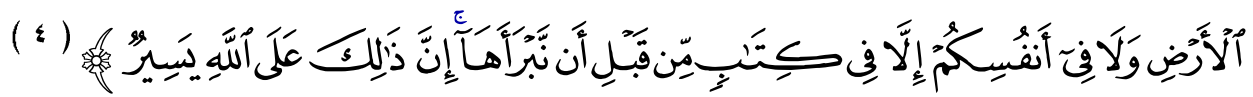
وروى الإمام مسلم ( • ) من حديث عَبْدِ اللهَّْْنِ عَمْرِو بْنِ الْعَاصِ قَالَ:سَمِعْتِ

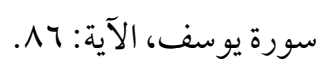

أبو القاسم عبد الكريم بن هوزان بن عبد الملك بن طلحة القشيري الخرساني النيسابوري

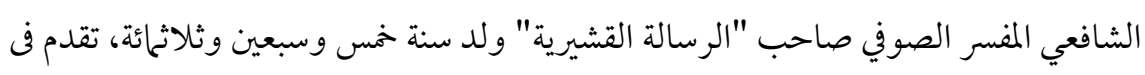
الأصول و الفروع وصحب العارف أبا على الدقاق، وتزوج بابتنه، وجاءه منها أولادًا نجباء، وله مصنفات كثيرة نافعة ، توفى سنة خمس وستين وأربعائة من الهجرة، وقد عاش تسعين سنة (سيرة

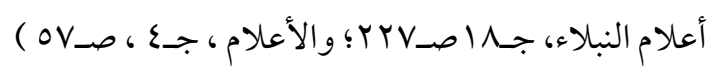

الرسالة القشيرية، صـ/ بr؛؛ مدارج السالكين بين منازل إياك نعبد وإياك نستعين،

$$
\begin{aligned}
& \text { جـا صـr •.0؛ جامع الأصول في الأولياء"الطرق الصوفية"، صـ.rY. }
\end{aligned}
$$

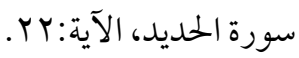

(•) الإمام مسلم بن الحجاج بن مسلم القشيري النيسابوري، أبو الحسن: حافظ من أئمة الحديث، $=$ 


\section{Cencon}

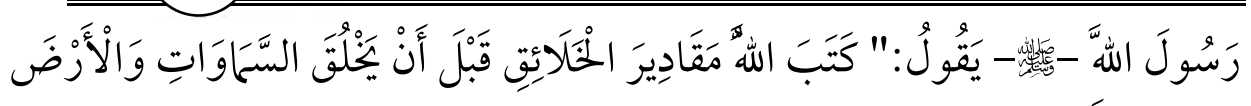

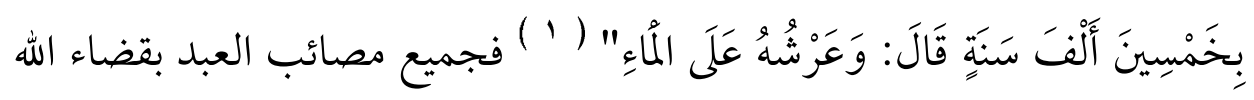
وقدره، قد سبق بذلك علم الله -تعالى - وجرى به قلمه، فلما يجزن المرء والأمر كله

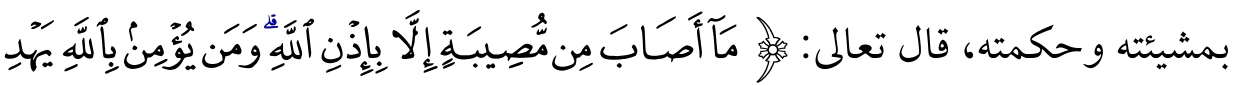

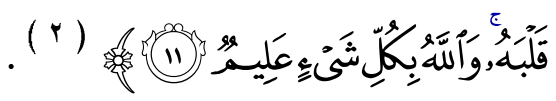
قال علقمة ( " ) : " هو الرجل تصيبه المصيبة، فيعلم أنها من عند الله، فيرضى

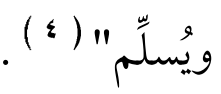

فالمؤمن مأمور بأن يرضى بها قسمه الله له،ويعلم أن ما أصابه لم يكن ليخطئه،

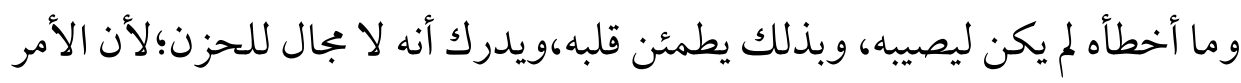
الإلهي ماض، والمشيئة الربانية نافذة،و أن ما ينتابه من حزن ونه على على حكام الدنيا، إنها هو

ولد سنة أربع ومائتين من المجرة في نيسابور، ورحل إلى الحجاز ومصر والشام والعراقهوتوفى

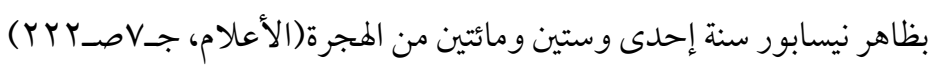

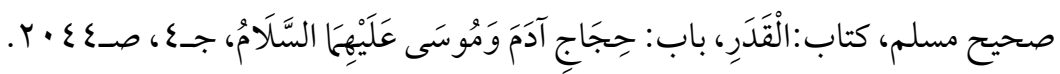

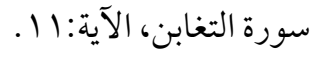

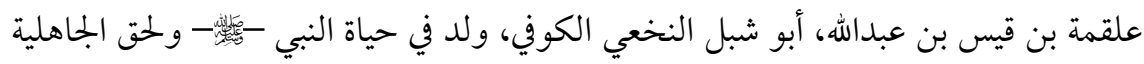

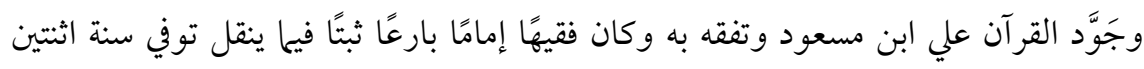

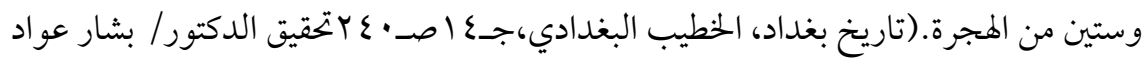

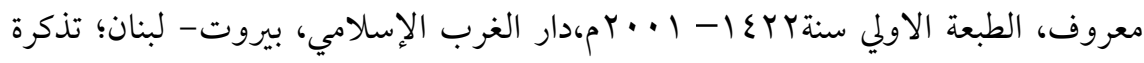

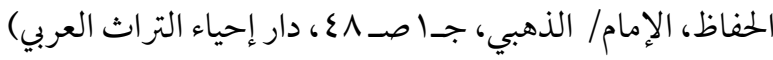

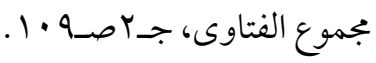




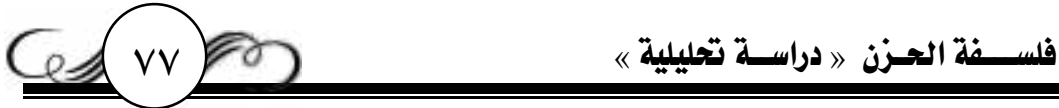

ناتج عن أفكار ووساوس شيطانية تدخل وتتعمق في فكر الإنسان، وتجعل كل همه الدنيا، ومما هو معلوم أن حب الدنيا هو رأس كل خطيئة.

رابعًا : الحزن المحرم ، هو الحزن على فوات معصية، يقول الإمام ابن القيم :

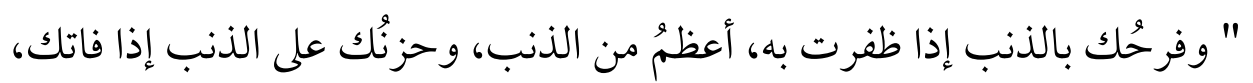

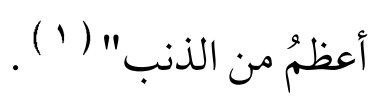

ومن هذا النوع، إذا صاحب الحزن ما يخرجه من الإباحة إلى الحرمة: كلطم

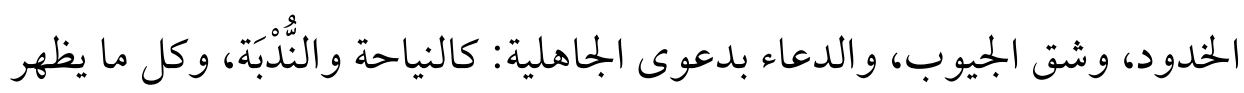

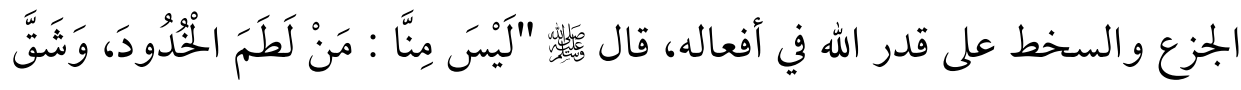

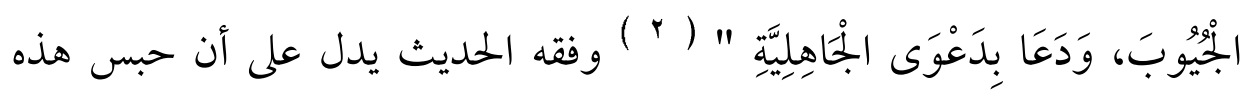
الأشياء هو حقيقة الصبر، فالصبر إذًا في الشرع هو: حبرِ حسبِ اللسان عن التشكي، وحبس القلب عن التسخط، وحبس الجوارح عن إظهار السخط بشق أو نحو ذلك.

ومن الحزن المحرمهما يكون على الخائنين لله ورسوله، ومن أعرضوا عن

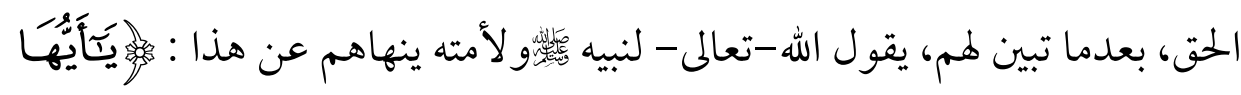

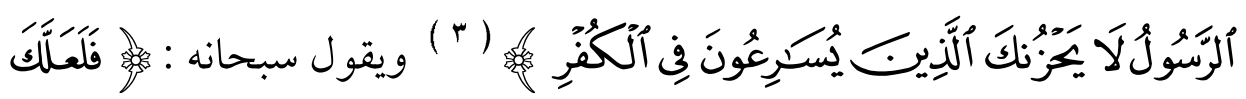

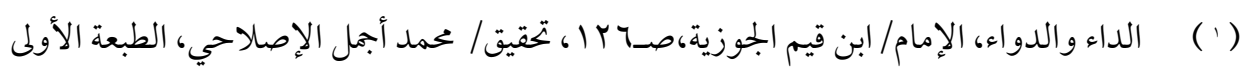
سنة 9 Y ( (هـ ، دار عالم الفو ائد، مكة المكرمة.

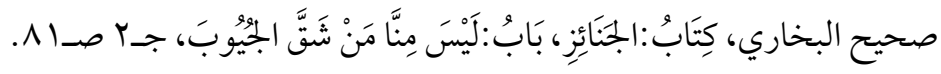
سورة المائدة، الآية:اعـ. 
Cيك

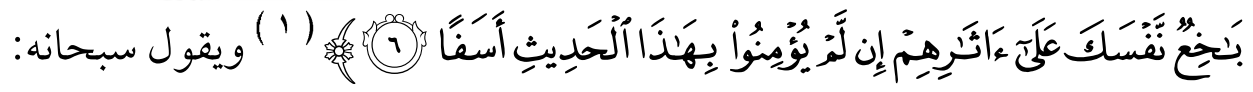

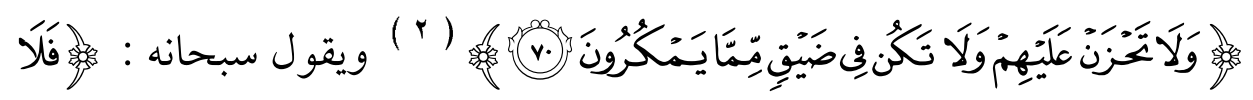

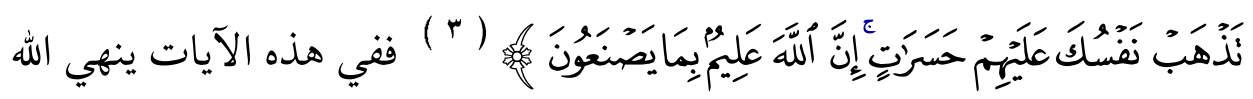

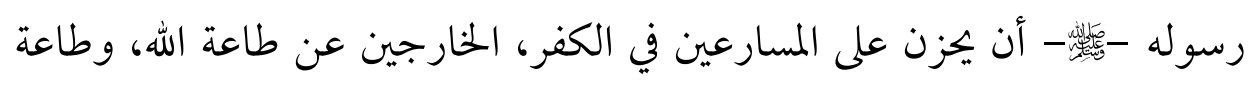

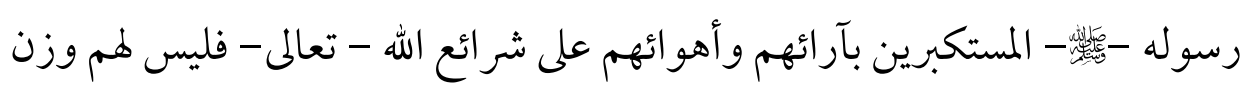
عند الله حتى يجزن عليهم المرء المسلم.

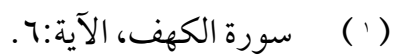

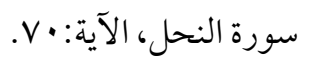

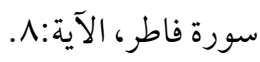


Gen
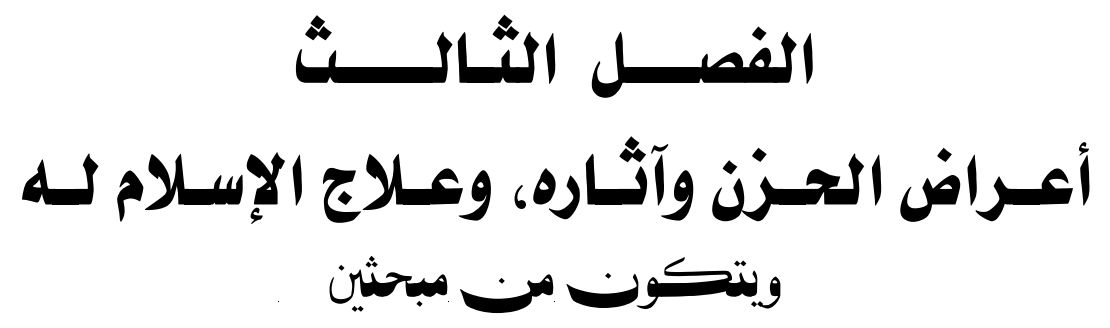

المبحـث الأول: أعـراض الحـزن وآثاره.

المبحث الثاني: عـلاج الإسـلام للحـزن . 


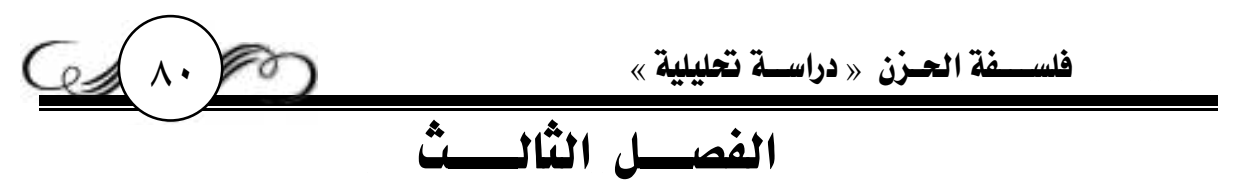

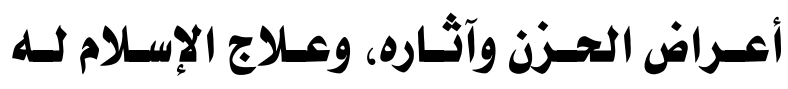 \\ المبحــ الأول : أعـراض الحسـزن وآثـاره .}

للحزن أعراض وجدانية، وأعر اض ذهنية، وأخرى بدنية: * أما الأعراض الوجدانية فتتمثل في : الون

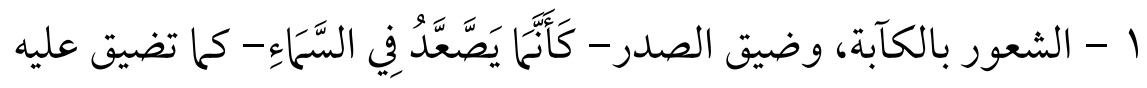
الدنيا بما رحبت، ومن ثم تضيق عليه نفسه التي بين جنبيه.

r - الانعزال واللجوء إلى الكهف المظلم، فلا يرى للأمل بصيصًا ولا

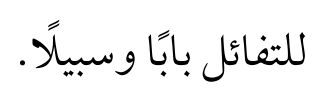
r - تفارقه السعادة والابتهاج، وتصاحبه الكر اهية لنفسه وللآخرين.

ع - الشعور باقتراب الأجل، والدخول في دائرة اليأس من رحمة الله، وعندها

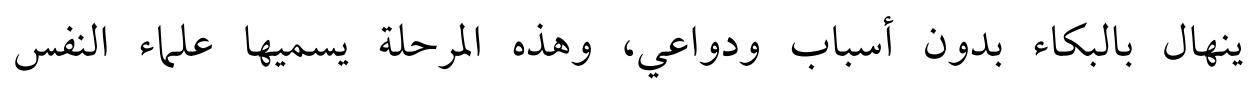
"بالاكئئاب" وهي مرحلة متقدمة من الحزن. * أما الأعراض الذهنية فنلاحظ عليه الآتي:

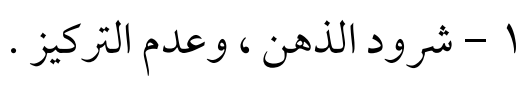

r - سبق الوهم إلى العكس، ومظاهر هذه النظرية تلاحظ في: أ - الفهم الخاطئ لمر اد الآخر، وما يكن به صدره. 


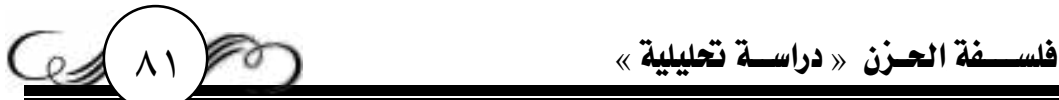

ب - الإصابة ببعض الأفكار الخاطئة،والشكوك المرضية،كالنظرة العدائية

من الآخر، والإحساس بعدم القبول من الناس خاصة، ومن المجتمع عامة.

r - سيطرة النفس اللوامة عليه في كل صغيرة وكبيرة، وبدرجة شديدة تعوقه

عن ممارسة حياته الاجتتاعية.

* أما الأعراض البدنية فأشدها وطأة على المصاب بالحزن.

1 - فقدان الشهية للطعام والشراب، مما يتسبب في خمول جسدي، وفتور

بدني.

r - تصاحبه في بعض الأحيان آلام متفرقة من بدنه.

r - أما حاله مع النوم، فطائفة من الناس عندما يمتلكها الحزن، ويسيطر

عليه الهم يخلد إلى نوم عميق، وسباط طويل على غير الطبيعي، وكأن هذا الحزن يتفاعل مع البدن كتفاعل المو اد الكيائية المهدئة والمنومة والتي تثبط الجهاز العصبي

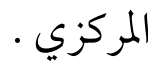

أما الطائفة الثانية، فيعانون من الأرق وعدم النوم، وكأن الحزن يعمل على له إطلاق بعض المواد المنبه - من خلال الجهاز العصبي والمخ - تؤدي بدورها إلى

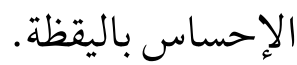

فالحزن من الانفعالات الطبيعية عند الإنسان، فهو عَرَض جبلي فطري ينتاب

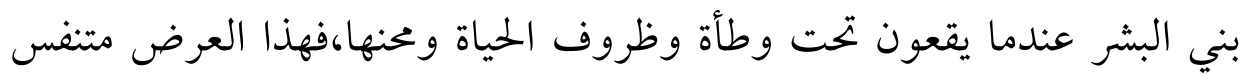




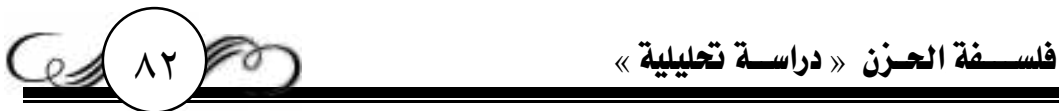

للتعبير عن الحالة المزاجية والوجدانية ولا يمكن الاستغناء عنه أو التخلص منه، ولذا يجب التحكم فيه وعدم الإسراف بحيث يصبح في حيز المعقول الذي يجعل الإنسان في حالة انسجام واتزان مع نفسه ومع الآخرين،أما الحزن الزائد عن حد المعقول،فقد يترك آثار جسيمة، ونتائج وخيمة على البدن.

فإذا ما تحققت الأعراض السابقة في شخص ما، ولم يستطع الخلاص منها فقد تؤثر على حياته، وبناءً على ذلك فإن الآثار المترتبة على الحزن الشديد إذا لم يكن الموت، فقد تجعل صاحبها يعاني من أعراض عصبية وتوترات حادة، وهذا ما كشفت عنه الأبحاث العلمية الحديثة، حيث يؤدي الحزن الشديد بصورة مباشرة إلى تلف خلايا المخ، و أكثر الناس حزنًا أقربهم للإصابة الدماغية.

إن الحزن يشل العقل فيعوقه عن القيام بدوره، وتولي مسئوليته وعمله، فلا تصل أو امره للأعضاء و الغدد، فينشأ عن هذا التوقف أمراضًا خختلفة، أبرزها سوء الهضم الذي ينتج عنه أمر اضًا كثيرة.

وتحليل آخر يوضح فيه الأطباء أن الحزن يمفز الغدد المسئولة عن هرمونات

التعصب" كهرمون الأدرينالين والكورتيزول" ومما هو معلوم أنه عند رفع إفراز هذه الهرمونات قد يصاب الإنسان بارتفاع ضغط الدم، وزيادة سرعة ضربات القلب، وارتفاع التنفس، يصاحب ذلك اضطرابات الهضم، وعلى أثر ذلك يسقط جهاز المناعة المسئول عن الحماية والدفاع، وهنا تبدأ الأمراض المختلفة بالهجوم على بدن الإنسان حتى تقضي عليه. 


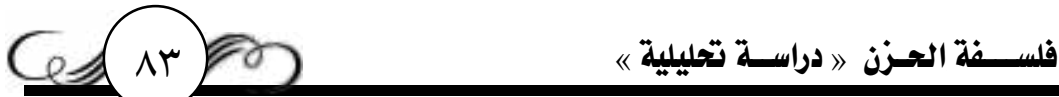

ومن جانب آخر يشير الدكتور"مانيو وافي"- أحد الباحثين في معهد بت

سيندا الدنحاركي - إلى أن هناك مركزين يقعان على جانبي الدماغ وهما مسؤولان عن حالات الإحساس والمشاعر، ويتحكمان في العواطف، ويتصديان لأي ضغوط عصبية وعاطفية، وإن الحزن الشديد يعرض خلايا جانبي المخ إلى التلف وهو ما قد يساهم في فقدان الذاكرة أو التعرض لإصابات دماغية أخرى ( 1 ). وقد أشار القرآن الكريم إلى هذه الحقيقة، ووضح أن الحزن سبب للوفاة، فقال - تعالى - لنبيه ومصطفاه هُ

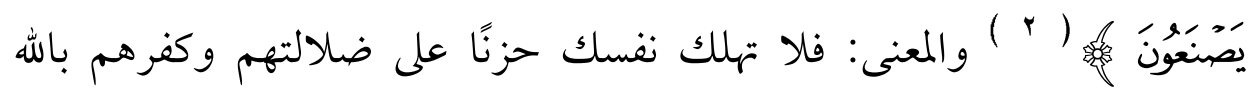
وتكذيبهم لك، فالذهاب بالنفس سبيه هو الحزن .

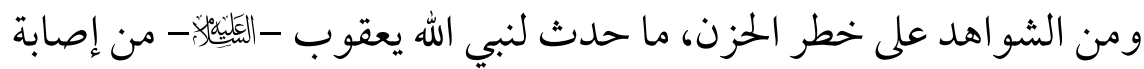

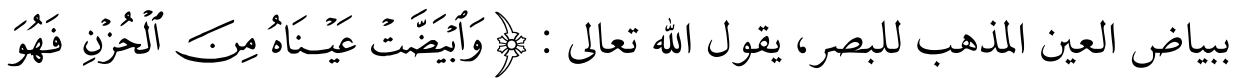

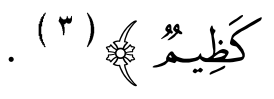

والحزن في هذه الآية يعكس بعدًا نفسيًا عميقًا، فقد كان لفقدان يوسف -

مقال بعنوان " الحزن والاكتئاب يؤديان إلى موت خلايا الدماغ " الدكتور / مانيو وافي، بتاريخ

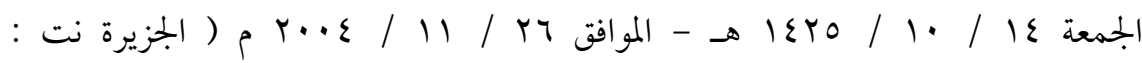

. ( www.aljazeera.net

$$
\text { سورة فاطر، الآية:^. }
$$




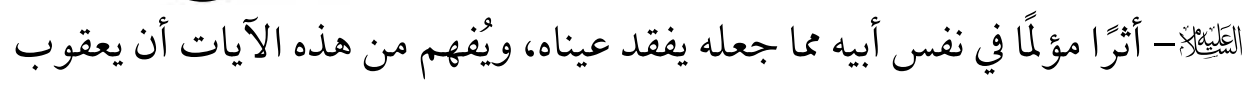
لم يكن فاقدًا لبصره، لكن المصائب الأخيرة وشدة حزنه ودوام بكائه أفقده بصره. ولقد اعتنى الإسلام عناية كبيرة بصحة الإنسان، فسن له المبادئ والأسس التي تحقق له حياة آمنة مطمئنة، خالية من الأمراض، ومن هنا كان لابد من وقفة مع الحزن، ولما لا وهو أحد المخاطر التي تهدد صحة الإنسان وتعرضها للخطر. 


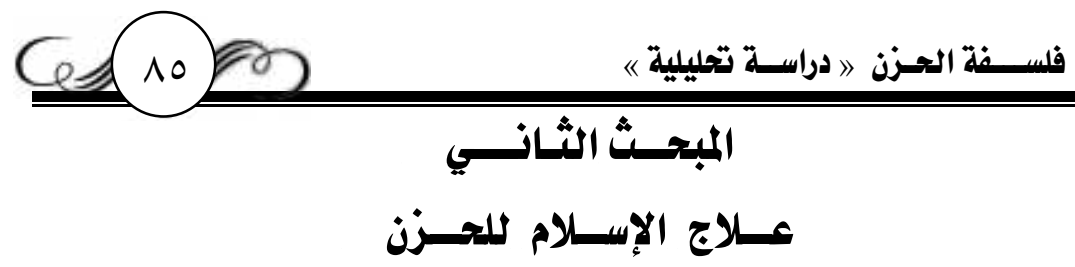

إن النفس الإنسانية تسعى دائمًا إلى جلب الفرح والسرور، ودفع الحزن والغم

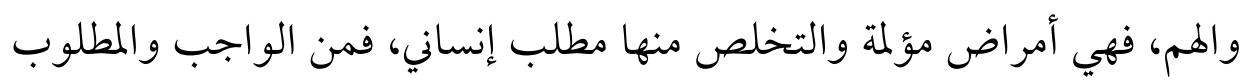
دفع هذه الآلام النفسية، مثلما نعني بدفع آلام أجسامنا، وعن هذا يقول الكندي:"فإصلاح النفس وإشفاؤها من أسقامها، أوجب علينا من إصلاح أجسامنا، فإننا بأنفسنا نحن ما نحن، لا بأجسامنا، وأجسامنا آلات لأنفسنا تطهر بها أفعالها، فإصلاح ذواتنا أولى بنا من إصلاح آلاتنا" ( ' ).

وفي سبيل الشفاء من هذا الداء العضال،يجب التضحية والصبر على العلاج أضعاف ما نتحمله في التخلص من المرض العضوي، مع العلم بأن التخلص من من منيل

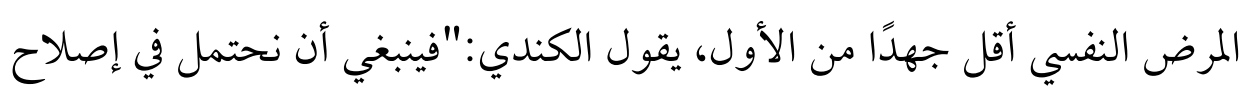

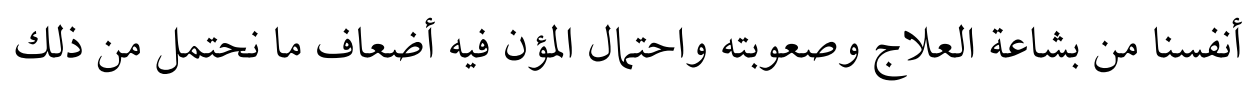
في إصلاح أجسامنا، مع أن إصلاح أنفسنا أقل بشاعة وأخف مؤونه كثيرًا ما يلحق

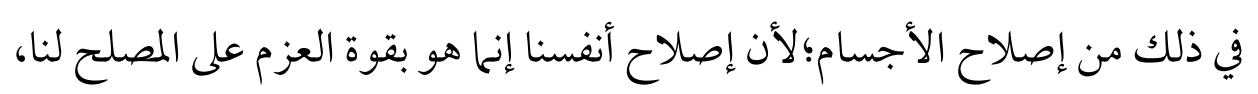

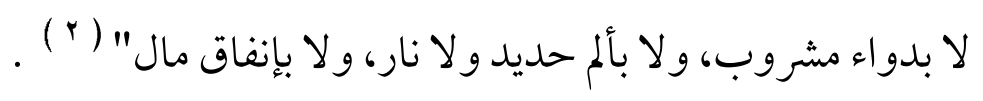
لهذا كان العلاج الإسلامي بعبادات جاء بها الشرع الشريف تبعث الطمأنينة

$$
\begin{aligned}
& \text { الكندي،رسالة في الحيلة لدفع الأحزان، ضمن رسائل فلسفية،صـا } 11 \text {. }
\end{aligned}
$$

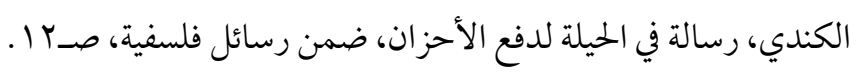




\section{Gen}

والسرور في القلب، فينشرح الصدر، وخلاف هذا العلاج لا يزيد المصاب إلا

خبالًا.

ولله در الإمام ابن القيم حين يصنف الهم والغم والحزن، ويلقي لنا الضوء

على الوسائل المشروعة والمحرمة في الإسلام، وآثارها على النفسية والمزاج فيقول:

مرض القلب نوعان:

النوع الأول: لا يتألمّ به صاحبه،كمرض الجهل، ومرض الشبهات

والشكوك، ومرض الشهوات؛ لأن سَكْرة الجحهل والهوى تحول بينه وبين إدراك

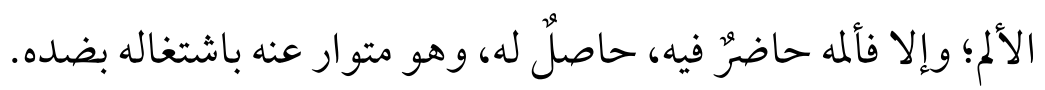

والنوع الثاني: مرض مؤلم له في الحال، كالهمّ والغمّ والحَزَن والغيظ، وهذا

المرض قد يزول بأدوية طبعية، كإزالة أسبابه، أو بالمداواة بـا يضاد تلك الأسباب،

ويدفع مُوجَبها مع قيامها.

وكما أن القلب قد يتألم بها يتألم به البدن، ويشقى بها يشقى به البدن، فكذلك

البدن يتألم كثيرًا بـا يتألم به القلب، ويُشقيه ما يُشقيه.

و أما أمر اضه التي لا تزول إلا بالأدوية الإيانية النبوية، فهي التي توجب له

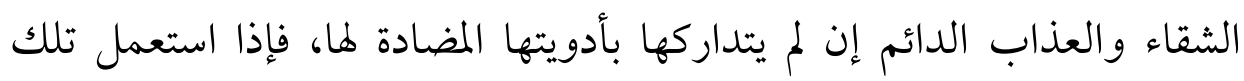

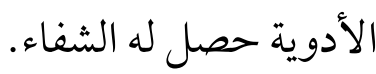

والغم والهم والحزن أمراض للقلب،وشفاؤها بأضدادها من الفرح 


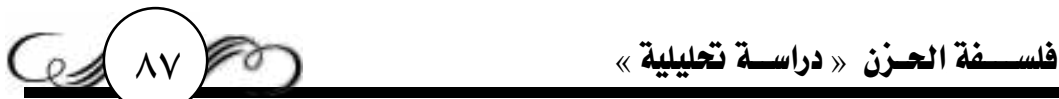

و السرور، فإن كان ذلك بحق اشتفى القلب وصحَّ وبرى من مرضه،وإن كان بباطل توارَى ذلك واستتر ولمَيَزْلْ، وأعقبه أمر اضًا هي أصعب و أخطر ( ) . وهذه الأمر اض قد تنوَّع الناس في طرق أدويتها، والخلاص منها، وتباينت طرقهم في ذلك، فكل واحد يسعى في التخلص منها، بما يظن أو يتوهم أنه يخلصه منها، و أكثر الطرق والأدوية التي يستعملها الناس في الخلاص منها لا يزيدها إلا شدة لمن يتداوى منها بالمعاصي على اختلافها، كالتداوي باللهو واللعب والغناء، وسحاع الأصوات المطربة وغير ذلك، فأكثر سعي بني آدم إنها هو لدفع هذه الأمور والتخلص منها، وكلهم قد أخطأ الطريق إلا من سعى في إزالتها بالدواء الذي وصفه الله لإزالتها، وهو دواء مركب من ججموعة أمور متى نقص منها جزء نقص

$$
\text { من الشفاء بقدره (r) و وهذا الدواء المركب - من بجموعة أمور - عبارة عن قسمين: }
$$

القسم الأول: استخدم الإسلام فيه دواء معنوي روحي، وذلك بالنصح والإرشاد، ومحاولة رفع معنويات المصاب، وتقوية نفسه.

القسم الثاني: استخدم الإسلام فيه ترياق حسي مادي له القدرة على إزالة

( ) إغاثة اللهفان في مصايد الشيطان، الإمام/ابن قيم الجوزية، جـاصـr ب، تحقيق/ حممد عزير شمس، الطبعة الأولى سنة بץ؟ أهـ، دار عالم الفو ائد، مكة المكرمة. شفاء العليل في مسائل القضاء والقدر والحكمة والتعليل،الإمام/ ابن قيم الجوزية، صـع بك،

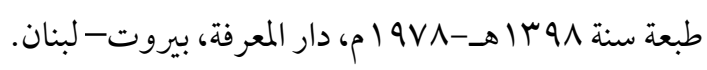




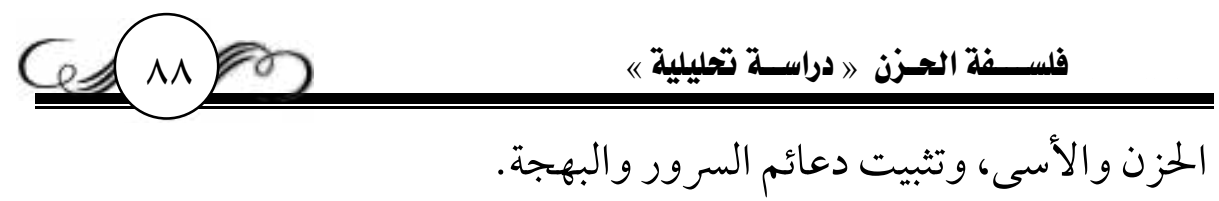

أما الأول: فللعقيدة الإسلامية دور فئَال في علاج حالات الحزن والاكتئاب من خلال نصوص الوحي الشريف، فلها بالغ الأثر على مشاعر الإنسان ونفسيته،

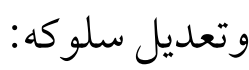

$$
\text { أولًا : آيات وأحاديث الإيهان بالقدر . }
$$

فإذا علم المرء واطمأن إلى أن المقادير تجري بمشيئة الله، وتيقن أنه لا يكون في أرض الله إلا ما أراد الله، وتحقق لديه أن كل قضاء لله خير، عندئذٍ لا يحق له أن

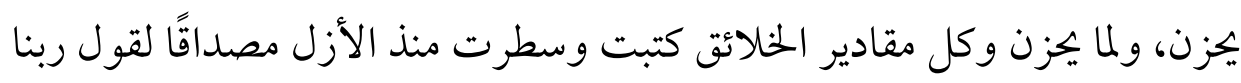

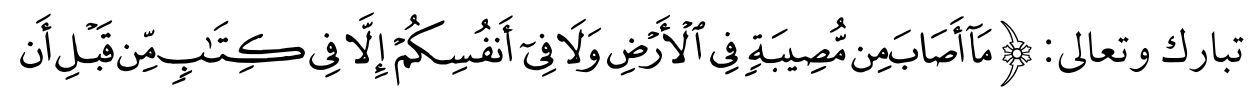

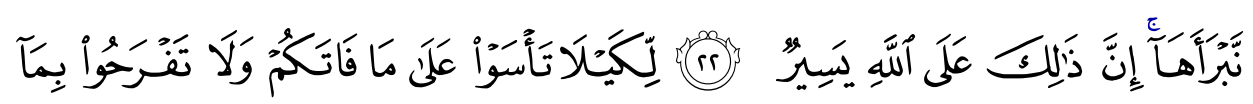

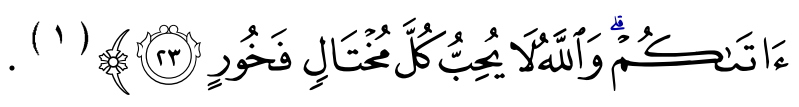
ومصائب الأرض هي: الأزمات التي يمر بها الإنسان في الشدائد التي تقابله

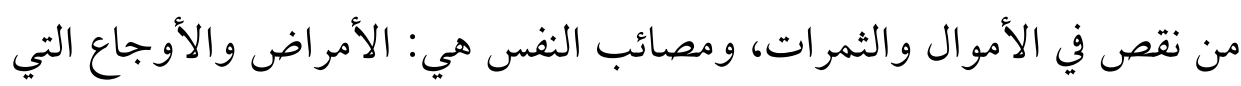
تلم بالمرء، وكل ذلك مكتوب ومستقر، فهذه الحوادث الأرضية قبل دخولها في الوجود لا ريب أنها مكتوبة في اللوح المحفوظ، وصدق رسول الله -

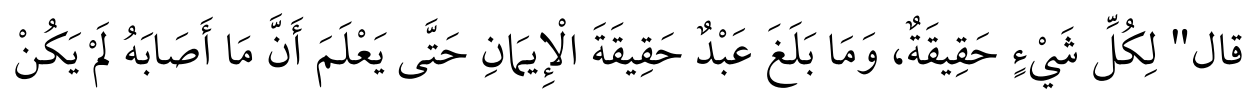




\section{Ces 19}

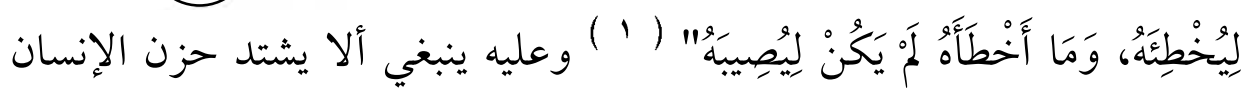
وفر حه، فمن عرف سر الله في القدر هانت عليه المصائب.

وتحقيق هذا الكلام على مذهب أهل السنة: أن وقوع كل ما وقع واجب،

$$
\text { وعدم كل ما لم يقع وأجب - أيضًا - لأسباب أربعة : }
$$

أحدها: أن الله - تعالى - علم وقوعه، فلو لم يقع انقلب العلم جهلًا.

$$
\text { ثانيها: أن الله أرادو وقوعه، فلو لم يقع انقلبت الإرادة تمنيًا. }
$$

ثالثها: أنه تعلقت قدرة اله - تعالى - بإيقاعه، فلو لم يقع لانقلبت تلك القدرة عجزًا.

رابعها: أن الله - تعالى - حكم بوقوعه بكلامه الذي هو صدق، فلو لم يقع لا نقلب ذلك الخبر الصدق كذبًا.

فالذي وقع لو لم يقع لتغيرت هذه الصفات الأربعة من كمالها إلى النقص، ومن قدمها إلى الحدوث، ولما كان ذلك متنغعًا علمنا أنه لا دافع لذلك الوقوع، وحينئذ يزول الغم والحزن عند ظهور هذه الخواطر، وهانت عليه المحن والمصائب ( ( ) . فاتساع أفق النظر، والتأمل مع الوجود الكبير، وتصور الأزل والأبد، ورؤية الأحداث في مواضعها المقدرة في علم الله، الثابتة في تصميم هذا الكون كل أولئك

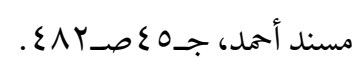

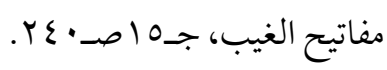




\section{QA. 9.}

يجعل النفس أفسح وأكبر ثباتًا ورزانة في مو اجهة الأحداث العابرة.

وإن الإنسان ييزع ويستطار وتستخفه الأحداث حين ينفصل بذاته عن هذا

الوجود، ويتعامل مع الأحداث كأنها شيء عارض يصادم وجوده الصغير، فأما

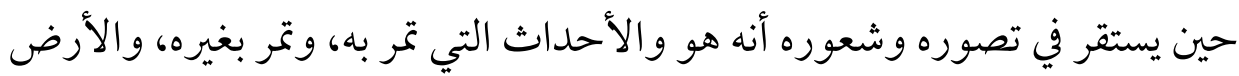
كلها ذرات في جسم كبير هو هذا الوجود، وأن هذه الذرات كائنة في موضعها في التصميم الكامل الدقيق، لازم بعضها لبعض، وأن ذلك كله مقدر مرسوم معلوم في علم اله المكنون، حين يستقر هذا في تصوره وشعوره، فإنه يجس بالراحة و الطمأنينة لمواقع القدر كلها على السواء، فلا يأسى على فائت أسى يضعضعه ويزلزله، ولا يفرح بحاصل فرحًا يستخفه ويذهله، ولكن يمضي مع قدر الله في طواعية وفي

رضى، رضى العارف المدرك أن ما هو كائن هو الذي ينبغي أن يكون ( ' ).

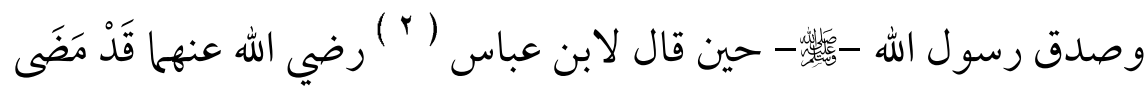

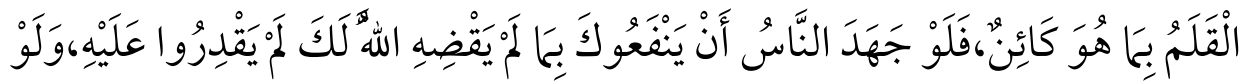

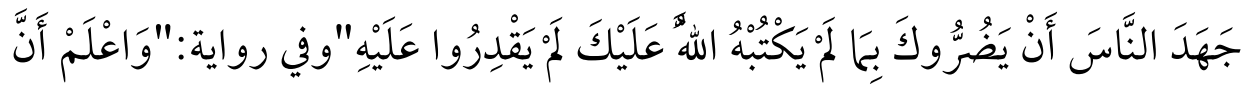

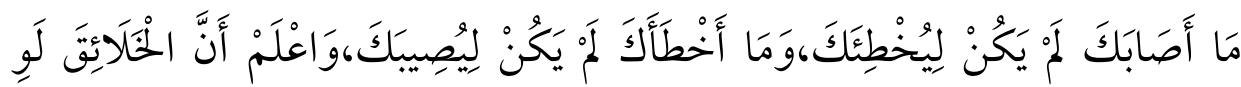

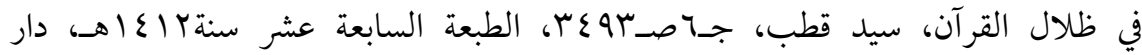

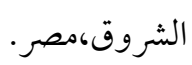

هو عبد الهّ بن عباس بن عبد المطلب بن هاشم بن عبد مناف بن قصى أبو العباس الهاشمي ابن

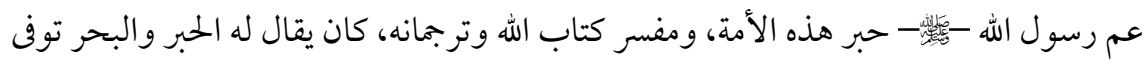

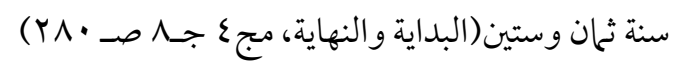




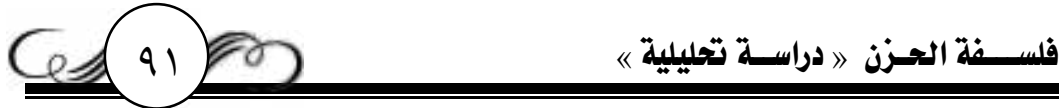

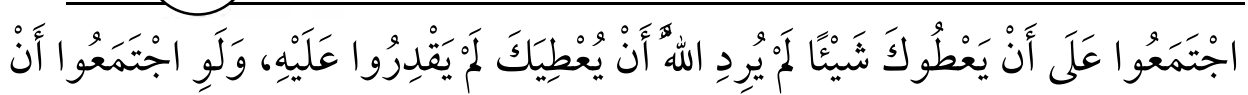

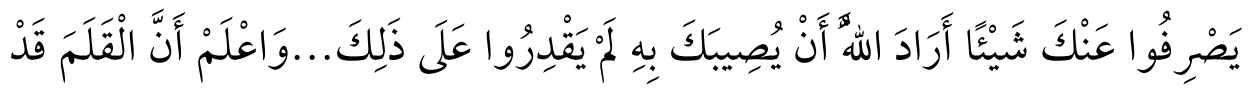

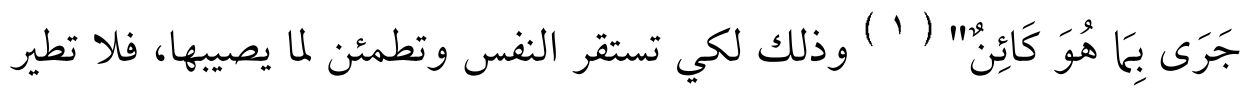
جزعًا وهي تو اجه الضراء، فكله بقدر مقسوم، ومرد الأمر كله في النهاية إلى الله لَّلالّ. والإيمان بقدر الله، والتسليم له عند المصيبة، سبب في الطمأنينة، والراحة النفسية، إذذ يقول الله تعالى :

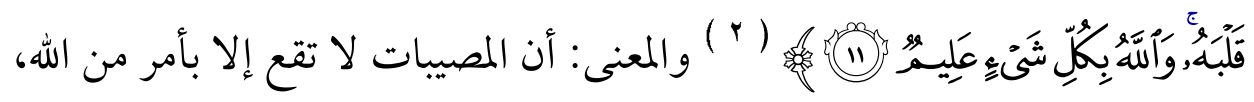

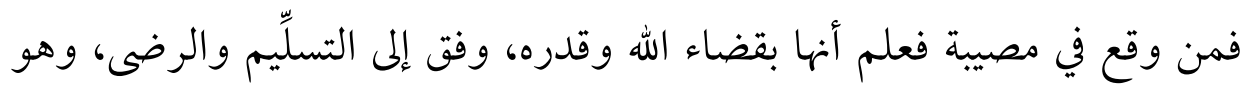
الهدى القلبي، ومن لم يؤمن بهذا عند نزول المصائب،فإن الله يكله إلى نفسه،و النفس ليس لديها إلا الجزع و الهلع المنهي عنه،و المعاتب عليه.

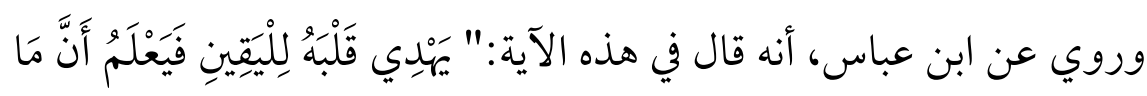

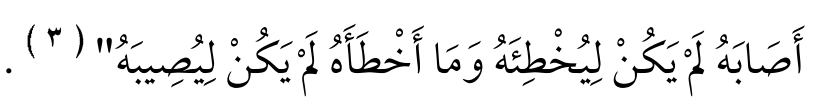

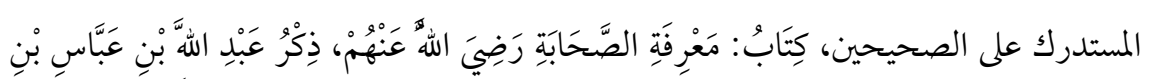

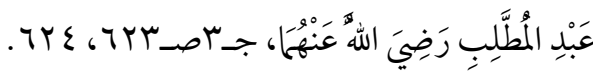

$$
\text { سورة التغابن، الآية:1 } 11 \text {. }
$$

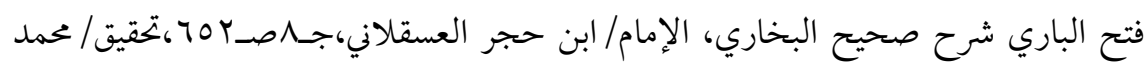

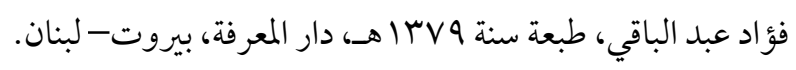




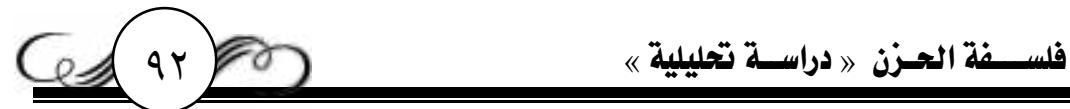

$$
\begin{aligned}
& \text { ثانيًا: مفهوم ودور الأحزان في الإسلام. } \\
& \text { إن الأحزان في الإسلام تكون: }
\end{aligned}
$$

أولًا: علامة من علامات محبة الله للعبد؛ لكونها مسببة عن الابتلاءات

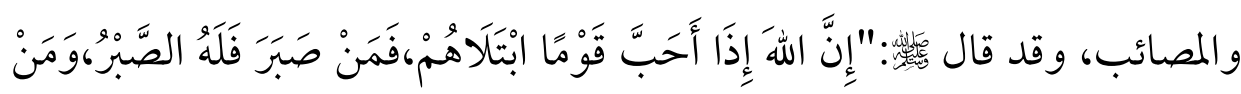
جَزِعَ فَلَهُ الَْزَعْع" ( 1 ) وهذا الحديث يدل على أن البلاء إنها يكون خيرًا،وأن صاحبه

$$
\text { يكون محبوبًا عند الله -تعالى - إذا صبر على }
$$

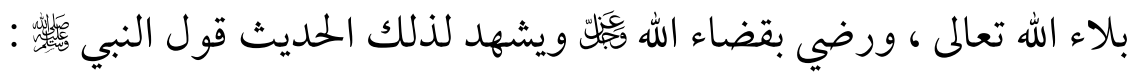

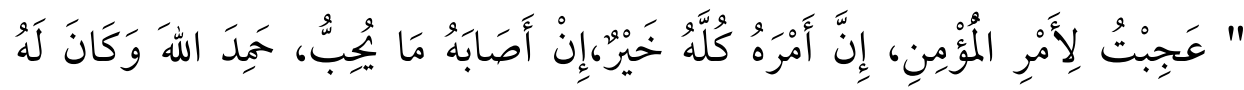

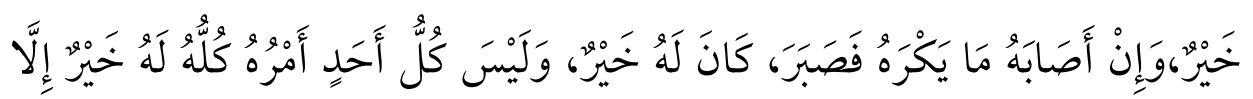

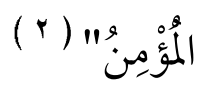

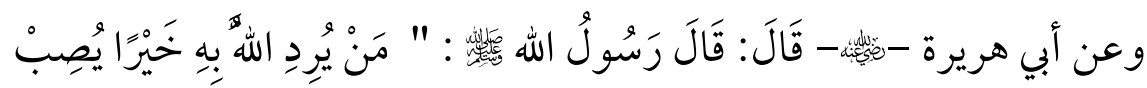

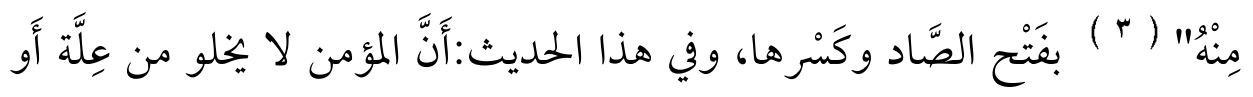

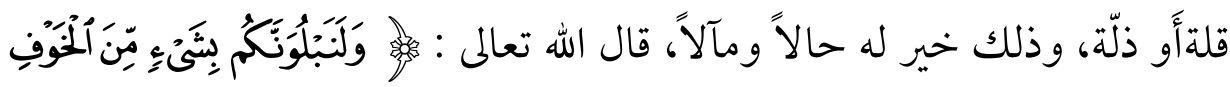

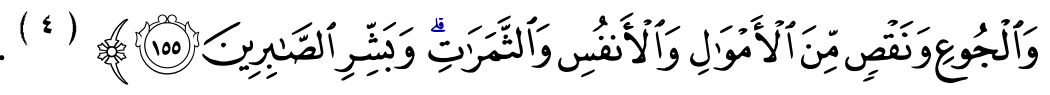

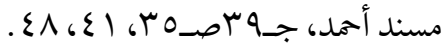

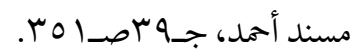

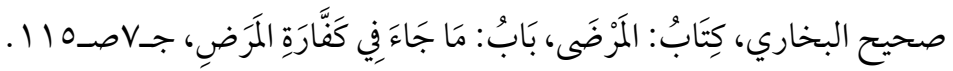




\section{Cen}

والابتلاءات وما يترتب عليها مقياسًا لإيمان العبد بمقتضى قول النبي

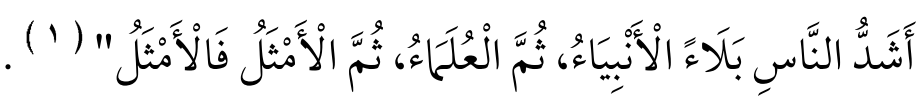

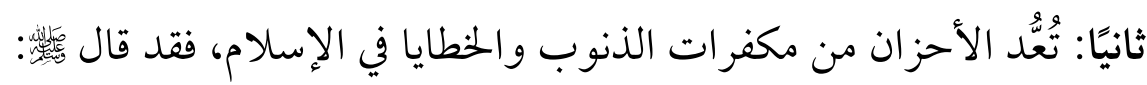

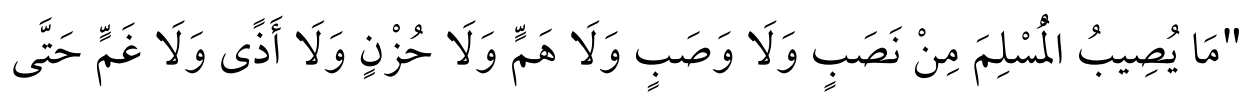

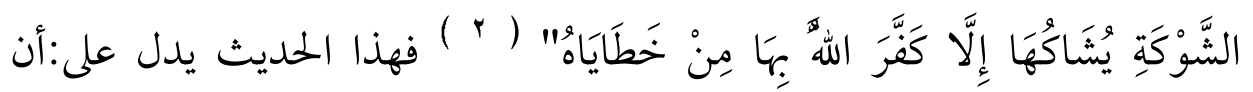

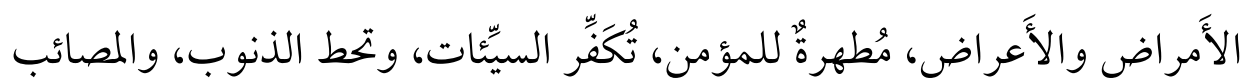

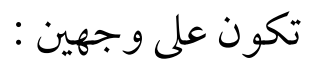

تارة إذا أصيب الإنسان تذكر الأجر واحتسب هذه المصيبة على الله، فيكون

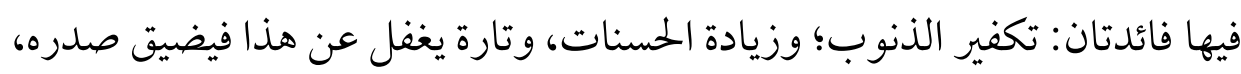

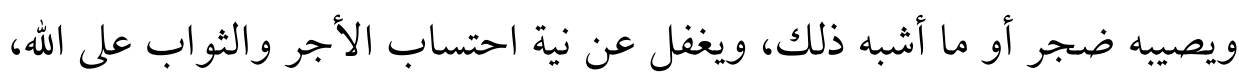
فيكون في ذلك تكفير لسيئاته، إذًا هو رابح على كل حال في هذه المصائب التي تأتيه. فإما أن يربح تكفير السيئات وحط الذنوب بدون أن يحصل له أجر؛ لأنه لم لم ينو شيئًا ولم يصبر ولم يحتسب الأجر، وإما أن يربح شيئين: تكفير السيئات،

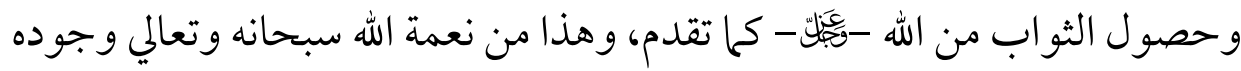

وكرمه، حيث يبتلي المؤمن ثم يثيبه على هذه البلوى أو يكفر عنه سيئاته ( " ).

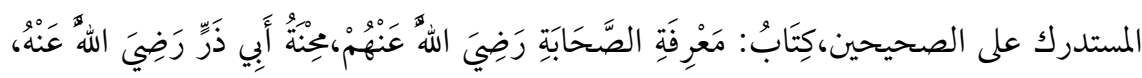

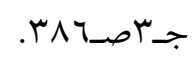

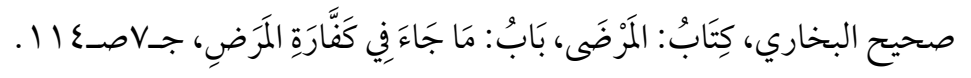

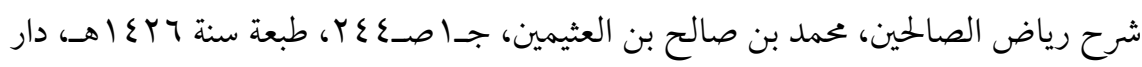

$$
\text { الوطن، الرياض- المملكة العربية السعودية. }
$$


إن هذه العقيدة، وتلك المفهوم لخير علاج لحالات الحزن والأسى، ومن ثم

التحول من السخط إلى الرضا، ومن الجزع إلى الصبر، ولنا في " الخنساء" ( 1 )

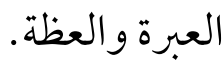

فهي المرأة المخضرمة التي عاشت في عصري الجحاهلية والإسلام، فكان لمبادئ وتعاليم الإسلام بالغ الأثر على تحول حالتها النفسية والمزاجية، ومن مظاهر هذا التغير: أنها بكت على أخيها "صخر" حتى عميت لحبها له حبًا شديدًا، كما رثثه ببالغ الحزن والأسى حتى ملأت الدنيا انتحابًا ودموعًا وعويلًا، وحفرت أشعارها حفرًا في قلب كل موتور حزين، وعبرت بأشعارها الرقيقة أصدق تعبير عن مرارة الثكل، وألم الموت، وصورت التجربة الإنسانية المؤلمة أدق تصوير، فكان شعرها خالدًا نحسه،ونتجاوب معه، وننفعل به ولقد عدت أعظم شعراء الرثاء، ويغلب على شعرها ظاهرة الحزن والبكاء والتفجع وذرف الدموع، ومن أبياتها التي تصور

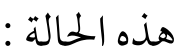

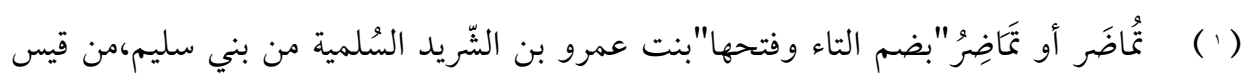

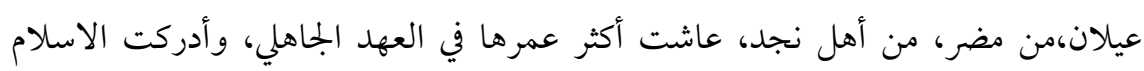

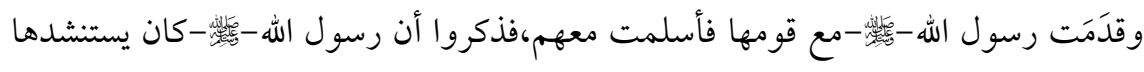

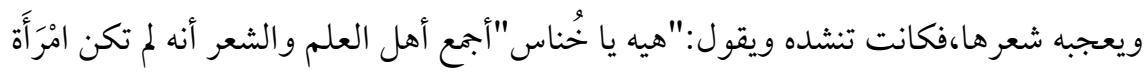

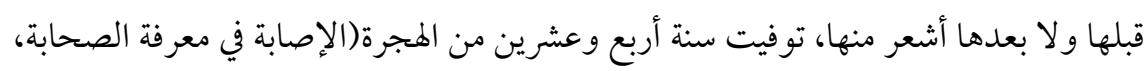

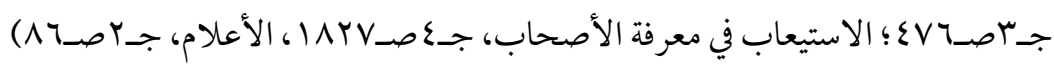




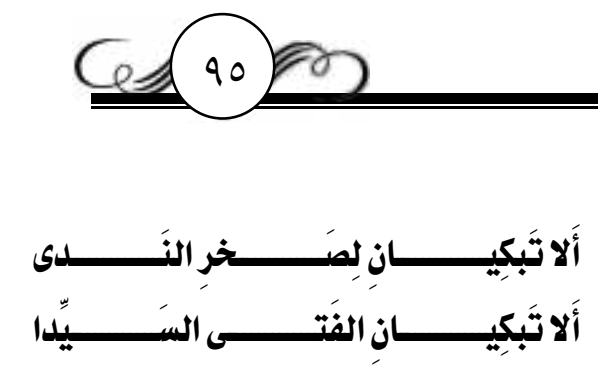

$$
\text { فمن المتقارب ( } 1 \text { ( تقول : }
$$
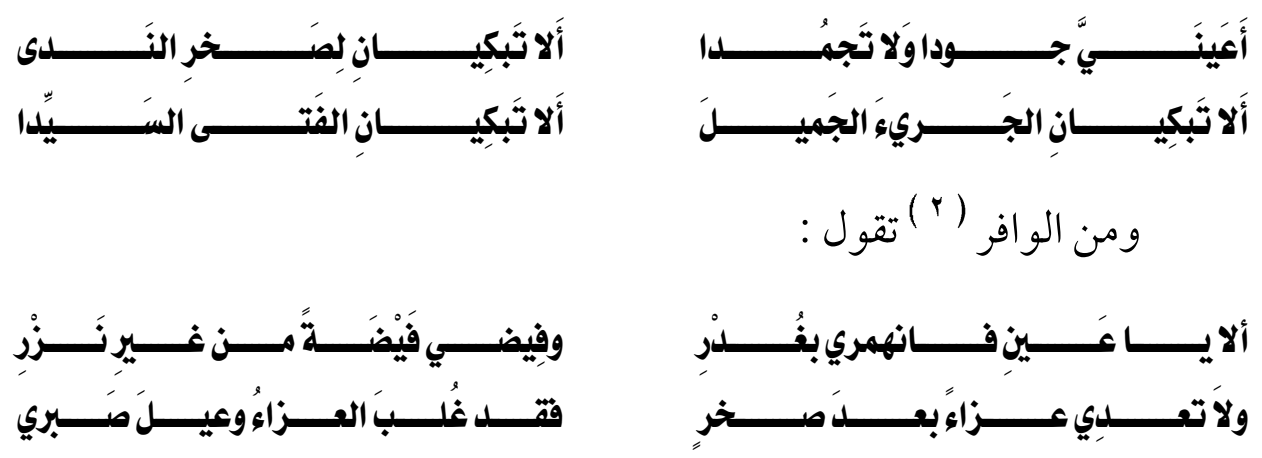

$$
\text { ومن البسيط تقول : }
$$

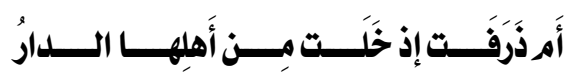

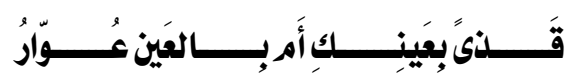

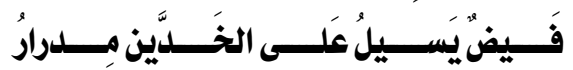

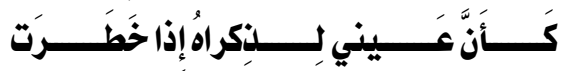

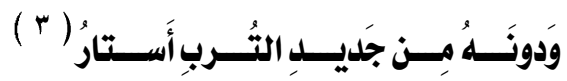

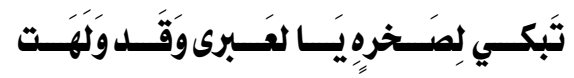
هذه هي حالتها في الجاهلية، أما في الإسلام فقد تغيرت تغيرًا جذريًا،فهي

سمي بهذا الاسم؛ لقرب أو تاده من أسبابه، والعكس بالعكس، فبين كل وتدين سبب خفيف

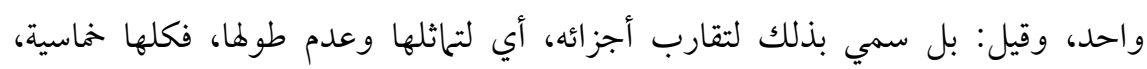

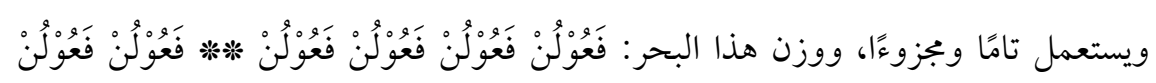

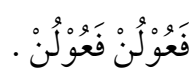
سُمِّيَ بهذا الاسم ؛ لوفور أوتاد تفعيلاته، وقيل : لوفور حركاته؛ لأنه ليس في تفعيلات البحور

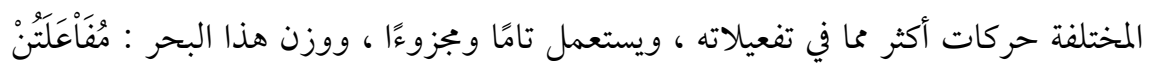

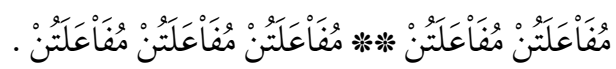
ديوان الخنساء، صدبr، اع، Yع،المكتبة الثقافية، بيروت - لبنان؛ ديوان الخنساء "شرح ثعلب"، صـه، تحقيق الدكتور / أنور أبو سويلم، الطبعة الأولى سنة 9 • ع اهـ - 9191 (م ، دار

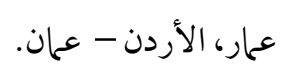




\section{فلســفة الحـزن 》د دراسـة تحليلية 《)}

التي حثت أبنائها الأربعة على الجهاد في موقعة "القادسية" ( 1 ) زمن أمير

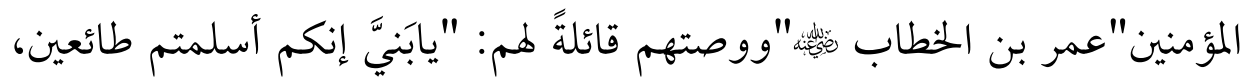
وهاجرتم غختارين...وقد تعلمون ما أعد الله للمسلمين من الثواب الجزيل في حرب

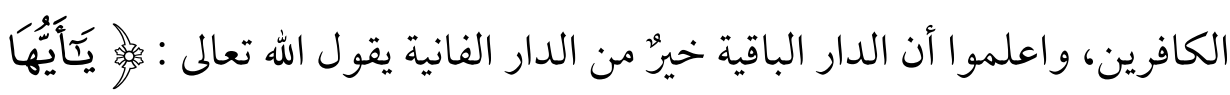

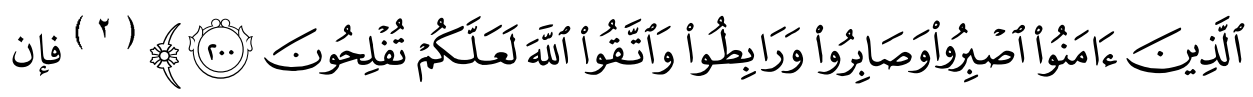
أصبحتم غداً إن شاء لله سالمين؛ فاغدوا إلى قتال عدوكم مستبصرين، تظفروا بالغنم والكرامة، في دار الخلد والمقامة، فخرج بنوها قابلين لنصحها عازمين على قولها، فلم) أضاء لمم الصبح باكروا مراكزهم، فقاتل أبناؤها فقتلو ا،فلم تجزع وتبك،ولكنها صبرت واحتسبت وقالت: "الحمد لله الذي شرفني بقتلهم، وأرجو من ربي أن يجمعني بهم في مستقر رحته" ( r ) ولم تحزن وتملئ الدنيا عويلاً وصر اخًا كما فعلت

كانت وقعة القادسية بالعراق في سنة أربع عشرة،وكان على الناس سعد بن أبي وقاص، وعلى المشركين رستم ومعه الجالينوس، وذو الحاجب و كان المسلمون ما بين السبعة إلى الثمانية آلافًا

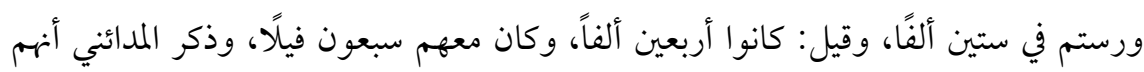

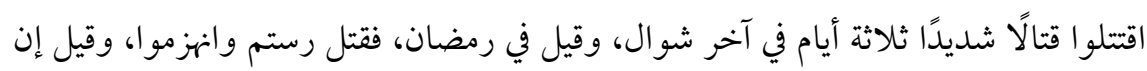
رستم مات عطشًا، وتبعهم المسلمون فقتل جالينوس وذو الحاجب، وقتلوهم ما بين الخرارة إلى لى السيلحين إلى النجف، حتى ألجأوهم إلى المدائن، فحصروهم بها حتى أكلوا الكلاب(تاريخ

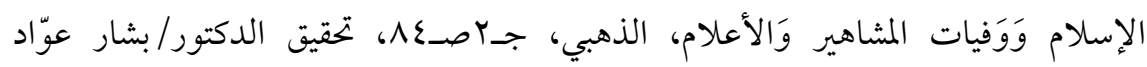

$$
\begin{aligned}
& \text { معروف، الطبعة الأولى سنة +. . مم، دار الغرب الإسلامي ) }
\end{aligned}
$$

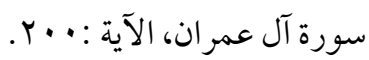

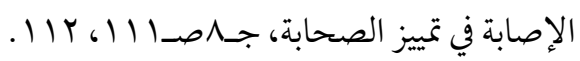




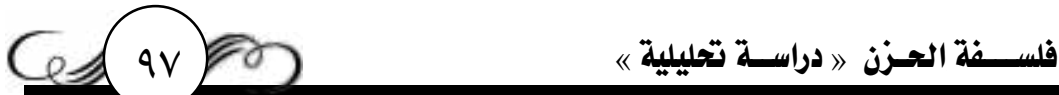

على أخيها صخر، إنه الإيمان حين يخالط بشاشة القلوب.

وعن دور الإيحان في إزالة الحزن، والتخلص من الهم والغم يقول الإمام عبد

القادر الجيلاني ( ' ) : " إذا أحكمت الإييان، وصلت إلى دار المعرفة، ثم إلى وادي العلم، ثم إلى وادي الفناء عنك وعن الخلقى، ثم إلى الوجود به لا بك ولا بهم،

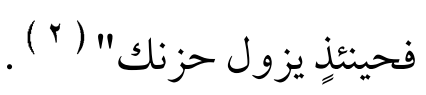

ولهذا الدور وتلك المفهوم كان للحزن منزلة عند الصوفية يجسن بنا والحالة

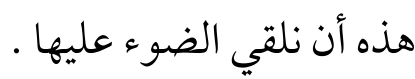

* مراتب الحزن ومكانتة عند الصوفية :

وللحزن ثلاث مراتب كما بين ذلك السادة الصوفية وهي :

المرتبة الأولى : حزن العامة وهو حزن على التفريط في الخدمة وعلى التورط في

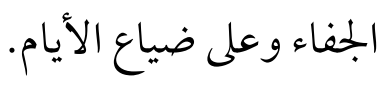

عبد القادر بن موسى بن عبد الله بن جنكي دوست الحسني، أبو محمد، محيي الدين الجيلاني، أو

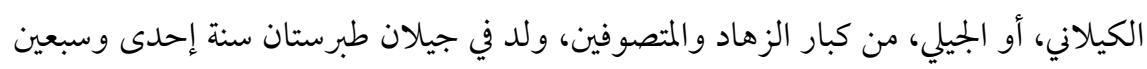

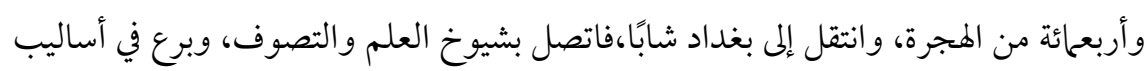

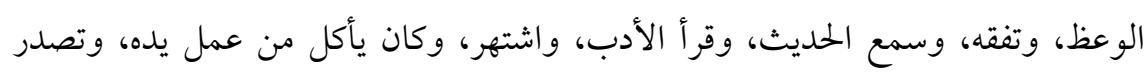

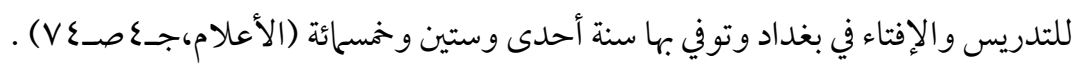
في الباطن والظاهر المسمى "جلاء الخاطر" الشيخ/عبد القادر الجيلاني، صـهه، تحقيق/ خالد

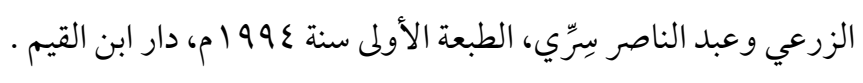




\section{فلســفة الحـزن 》 دراسـة تحليلية 《)}

ومعنى هذا الكلام : أن السابق إلى قلوب المقصرين حزنهم على التقصير؛

والتقصير يكون إما لشغل بالدنيا وهو التورط في الجفاء، أو لكسل عن أعلال الأخرى وهو التفريط في الخدمة، أو لفكرة فيها مضى وهو سبب الندم على ما ضاع

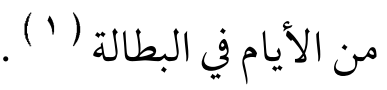

والمرتبة الثانية : حزن أهل الإرادة وهو: حزن على تعلق القلب بالتفرق، وعلى اشتغال النفس عَن الشهود، وعلى التسلي عن الحزن . وهذا الحزن أرفع مما قبله بالنظر إلى متعلقه وله أسباب ثلاث :

الأول : الحزن على تعلق القلب بالتفرق، أي بالأكوان والخلائق بالمحبة،قال

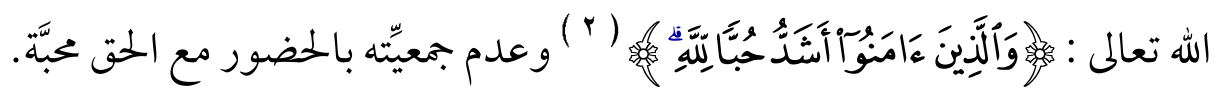
الثاني : الحزن على اشتغال النفس، أي بالحياة الدنيا وملاهيها، عن ذلك الحضور

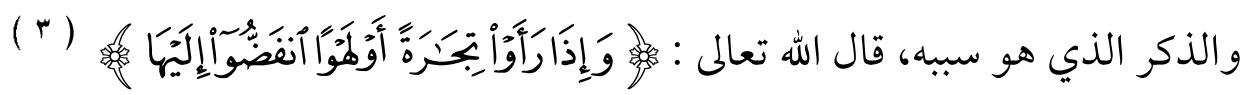

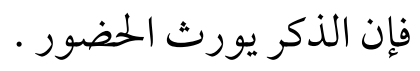

الثالث : الحزن على التسلي عن الحزن، وذلك إذا فقده المريد في وقت النقص وضيعة الأيام بالبطالة والتفرقة، فإنه إذا لم يمزن حينئذ بقى مع القصور؛ فهو مقام

$$
\begin{aligned}
& \text { شرح منازل السائرين، اللخمي، صـ.ع. } \\
& \text { سورة البقرة، الآية:170. } \\
& \text { سورة الجمعة، الآية : 11. }
\end{aligned}
$$




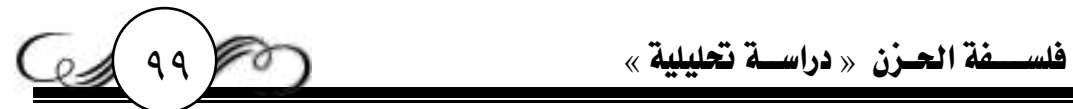

شريف في حقه، فإذا فقده حزن على فقده ( 1 ().

والمرتبة الثالثة من الحزن: التحزن للمعارضات دون الخواطر، ومعارضات

$$
\text { القصود، والاعتر اضات على الأحكام • }
$$

وهذه الرتبة أتم مما قبلها من الدرجات، فإن الذي قبلها حزن على التفرقة،

وسعي في طلب مقام الجمع، وهاهنا حزن للمعارضات على مقام الجمع، و العارضات المشغلة عن المقصود وعلى وجود الاعتر اضات على الأحكام، الجارية بين الأنام، بل حقه أن يتلقاها بالقبول والاحترام، ما لم تكن من الآثام ( ب ) وهذه المرتبة من الحزن لها ثلاثة أسباب :

الأول : التحزن للمعارضات دون الخواطر، ويعني ذلك معارضات معاني التجليات؛ فإن من حصل له التجلي من عالم الجمال يتعلق بالبسط، فإن المعارضة في حقه تكون من تجلي آخر من عالم الجلال، فيتعلق بالقبض فيحزن ضرورةً على عالم الجمال

الثاني : الحزن على معارضات القصود، أو المعارضات المشغلة عن المقاصد، وهو ما ينقض عزائمهم من قبل الله، فربها قصدوا طريقًا يسلكونه في الله - تعالى باختيارهم، فاختار الله - تعالى - هم طريقًا آخر - يعلم أنه أولى بهم وأليق فيعارضهم في ذلك، ويسلكهم فيا هو أولى بهم وأليق، فيحزن على أن لم يجصل له

$$
\text { شرح منازل السائرين، القاساني، صـا ـ 1، ؟ +1. }
$$




\section{Gen}

الثالث : الحزن من أجل الاعتراض على الأحكام، وهي أن يخطر لهم خواطر

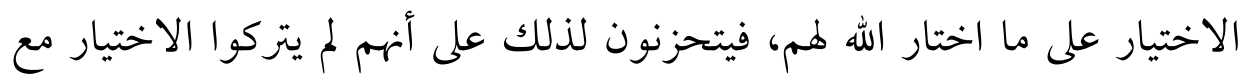

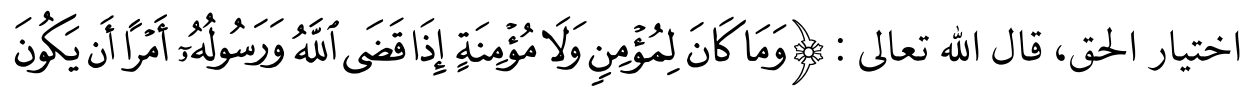

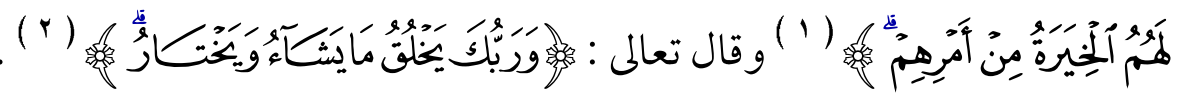
وقد يقع منهم الاعتراض على الأحكام الواردة عليهم من الحق غلبة، فيتحزنون لما صدر عنهم من سوء الأدب، أو على أحكام العلم عند غلبة الحال، وهجوم المعرفة في تلويناته ؛ فإذا تمكنو اعرفو اصحة العلم الظاهر في طوره، وصحة الحال والمعرفة في طورهما، فيتحزنون لما فاتهم من التسليم للعلم، وتسرعهم في الاعتر اض على الله (r) ). كما أن له وجوه، يقول الشيخ حاتم الأصم ( ؛ ) : " الحزن على وجهين: حزن

$$
\begin{aligned}
& \text { ( ) سورة الأحزاب، الآية:جr. } \\
& \text { سورة القصص، الآية:11. } \\
& \text { شرح منازل السائرين، القاساني، صـه • 1. }
\end{aligned}
$$

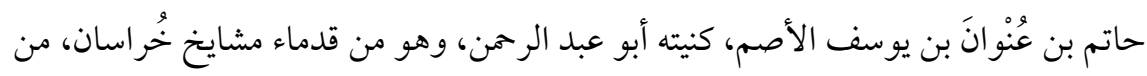

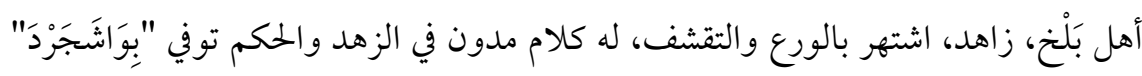

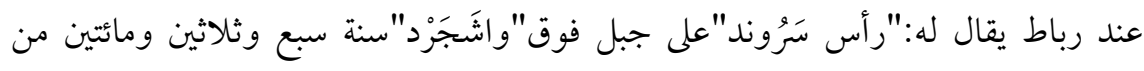

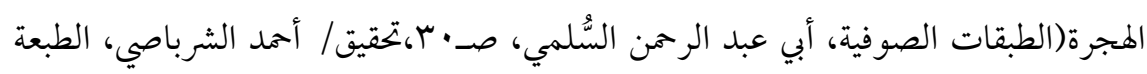

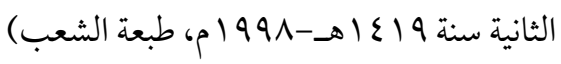




\section{cos.}

لك، وحزن عليك فأما الذي عليك فكل شيء فاتك من الدنيا فتحزن عليه فهذا عليك، وكل شيء فاتك من الآخرة وتحزن عليه فهو لك" ( 1 ( ) ويقول الشيخ الحارث المحاسبي ( † ) الحزن على وجوه: " الحُزن على وُجُوه

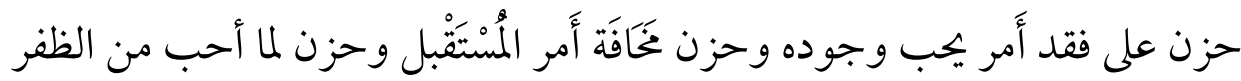

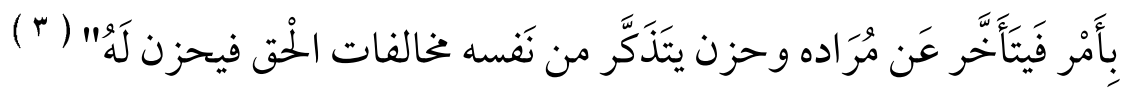
والحزن من أوصاف أهل السلوك، يقول الإمام ابن القيم: "وليست من

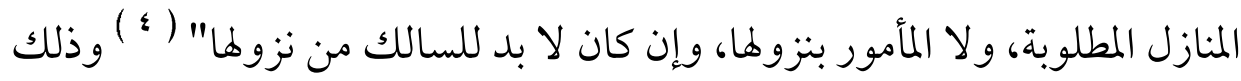
لأنه من ثمرة أعمالهم، وتجليات عبودياتهم في حال سيرهم .

حلية الأولياء وطبقات الأصفياء، أبو نعيم الأصبهاني، جـ. اصــء، طبعة سنة؟؟باهـ-

$$
\text { ع ع أم، دار السعادة،مصر. }
$$

الحارث بن أسد المحاسبي،أبو عبد الله:من أكابر الصوفية، كان عالما بالأصول والمعاملات، واعظًا مُبكيًا، وله تصانيف في الزهد والرد على المعتزلة وغيرهم، سمي المحاسبي؛ لأنه كان يجاسب نفسه، ولد ونشأ بالبصرة،، مات ببغداد سنة ثلاث وأربعين ومائتين من الهجرة(طبقات

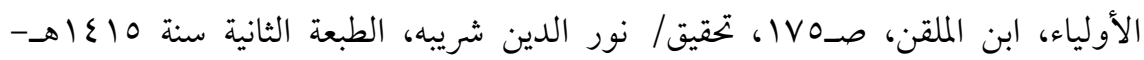

$$
\text { ع } 99 \text { (م)، مكتبة الخانجي، بالقاهرة) }
$$

طبقات الصوفية، أبو عبد الرحمن السلمي، صـا7، تحقيق/ مصطفى عبد القادر عطا، الطبعة

$$
\text { الأولى سنة } 9 \text { اع ( هـ - } 991 \text { (م)، دار الكتب العلمية، بيروت- لبنان. }
$$




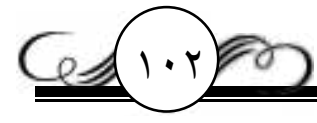

$$
\text { يقول الإمام ابن عربي ( } 1 \text { في مقام الحزن من البسيط : }
$$

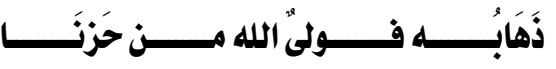

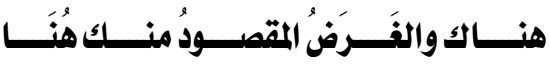

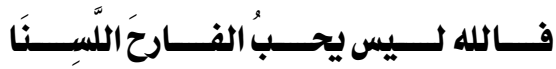

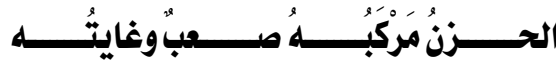

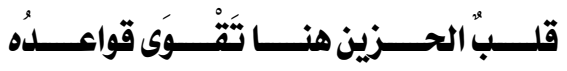

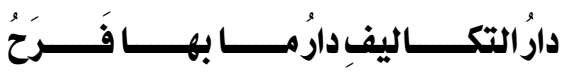

ويقول: الحزن مقام صعب المرتقى قليل من الخلق عليه هو للكملة من الناس

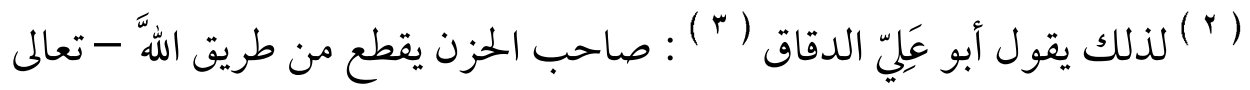
- في شهر مالا يقطعه من فقد حزنه سنين ولعل ذلك سببه؛ أن من حزن على التقصير جدَّ في التحصيل، ومن خشى الفوات اجتهد قبل الممات ( ؛ ) .

محمد بن علي بن محمد ابن العربي، أبو بكر الحاتي الطائي الاندلسي، المعروف بمحيي الدين بن (')

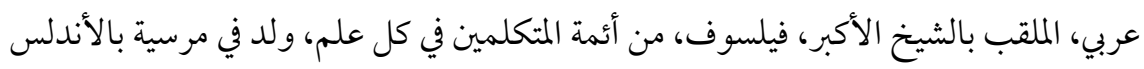
سنة ستين وخمس مائة، وانتقل إلى إشبيلية ، وقام برحلة، فزار الشام وبلاد الروم والعراق والحجاز، واستقر في دمشق، فتوفي فيها سنة ثلان وثلاثين وستحائة، وله نحو أربعمائة كتاب

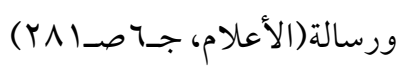

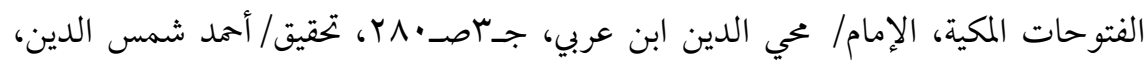

$$
\text { الطبعة الأولى سنة • بع اهـ - 1999 1م، دار الكتب العلمية، بيروت - لبنان. }
$$

الحسن بن علي بن محمد أبو علي الدقاق، الزاهد النيسابوري شيخ الصوفية، وشيخ القشيري، لسان وقته وإمام عصره بعلم العربية، وعلم الأصول، توفي في ذي الحجة سنة ست وأربعمائة

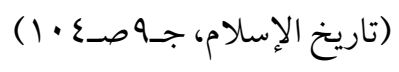

حاشية العلامة مصطفى العروسي المسماة : نتائج الأفكار القدسية في بيان معاني شرح الرسالة

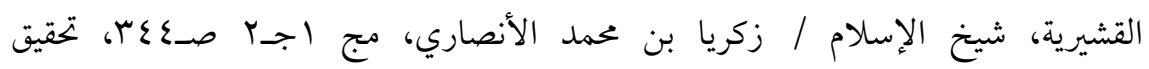

$$
\text { الشيخ/ عبدالواث محمد علي، دار الكتب العلمية، بيروت-لبنان. }
$$




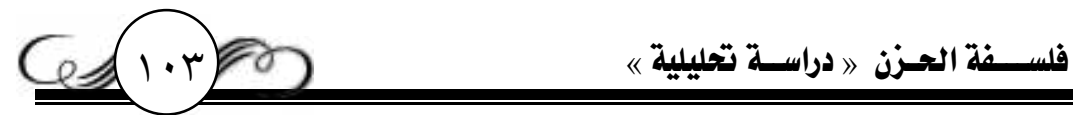

وتعتقد الصوفية: أن القلب إذا لم يكن فيه حزن خرب كما أن الدار إذا لم يكن فيها ساكن تخرب، وقد يكون السبب لحصول ضده .

وقال أبو سعيد القُرَبيّيَ ( ' : " "بكاء الحزن يعمى وبكاء الشوق يعشى البصر

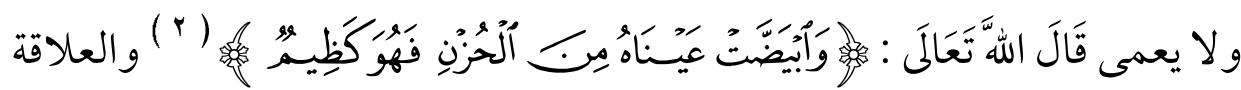
بين العمى والحزن، أنه كمات تقول الصوفية: يمنع من الطعام والشراب، ويكثر معه الهموم و الغموم، فتصعد من المعدة أبخرة رديئة مظلمة تكون سببًا لزوال الإدراك

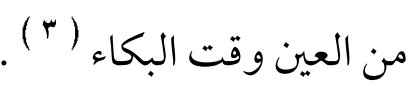
سمعت رابعة العدوية ( ؛ ) سفيان الثوري ( • ) يقول: واحزناه فقالت :" قل (') عبد الله بن محمد بن عبد الوهاب بن نصير بن عبد الوهاب بن عطاء بن واصل، أبو سعيد

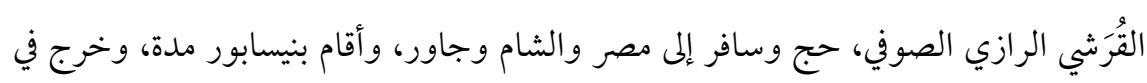

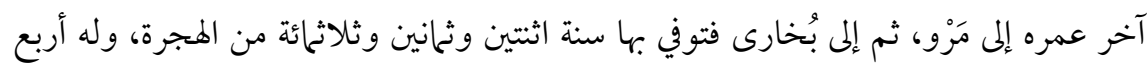

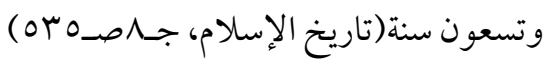

$$
\begin{aligned}
& \text { سورة يوسف، الآية:عـ. }
\end{aligned}
$$

حاشية العلامة مصطفى العروسي المسمة: نتائج الأفكار القدسية في بيان معاني شرح الرسالة

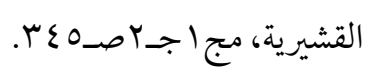

رابعة ابنة إساعيل العدوية البصرية مولاة آل عتيك، الصالحة المشهورة، كنيتها أم عمرو، كانت

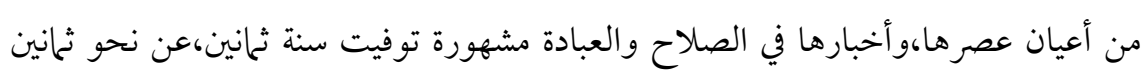

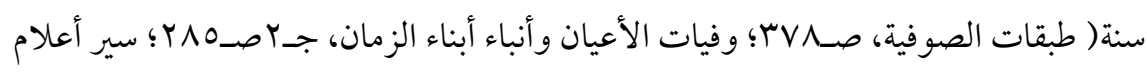

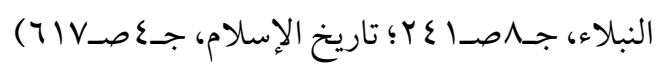

سفيان بن سعيد بن مسروق بن حبيب بن رافع بن عبد الله بن موهبة بن أبي ابن عبد الله بن منقذ $=$ 


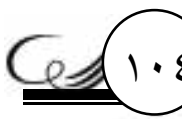

واقلة حزناه لو كنت مخزونا لم يتهياً لك أن تتنفس" ( 1 ( ) تعني لم تتفرغ للاستغاثة

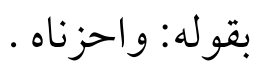

وقال سفيان بن عيينة ( r ): " لو أن مخزونًا بكى فِي أمة لرحم اللَّهَتعالى -

تلك الأمة ببكائه "وذلك لأن المحزون شديد الاضطرار إلى ما حزن عليه،وعند

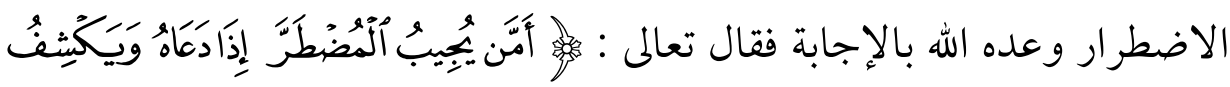

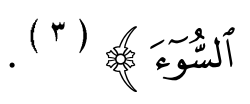

وكان داود الطائي ( ؛ ) يغلب عليه الحزن ويقول بالليل: إلهي همك عطل علي

بن نصر بن الحارث بن ثعلبة بن عامر بن ملكان بن ثور، إمام الحفاظ، أبو عبد الله الثوري

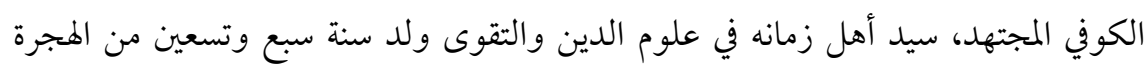
اتفاقًا، ونشأ في الكوفة، وخرج منها إلى البصرة سنة خمس وخمسين ومائة، أمير المؤمنين في الحديث، توفي-قئلة-بالبصرة سنة إحدى وستين ومائة من الهجرة (سيرة أعلام

$$
\begin{aligned}
& \text { النبلاءج_V_r (Y ) }
\end{aligned}
$$

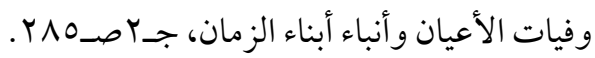

سفيان بن عيينه بن ميمون الهلالي الكوفي، أبو محمد، محدث الحرم المكي من الموالي، ولد بالكوفة

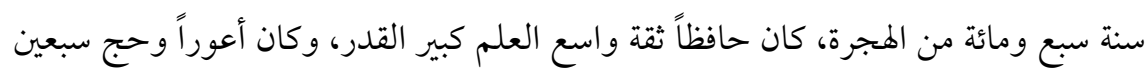

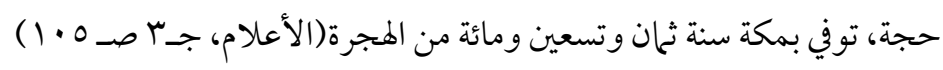

$$
\text { سورة النمل، الآية:rابل. }
$$

داود الطائي أبو سليان بن نصير الإمام، الفقيه، القدوة، الزاهد، الطائي، الكوفي، أحد الأولياء،

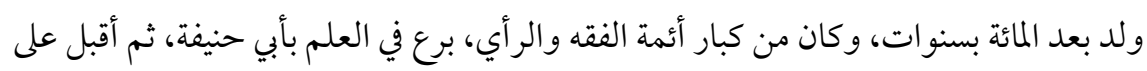

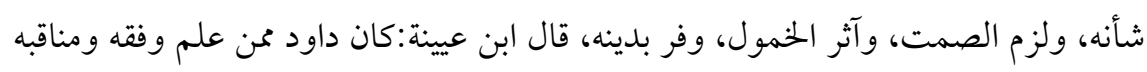
$=$ 


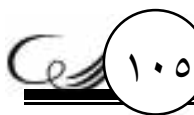

الهموم وحال بيني وبين الرقاد وكان يقول: كيف يتسلى من الحزن من تتجدد عليه

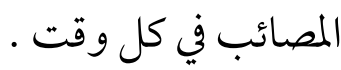
وسئل بعضهم بم يستدل على حزن الرجل فقال: بكثرة أنينه ؛ لأن من تراكم عليه ألم الحزن، عسر عليه التعبير بلسانه، وإنما يتنفس ويتروح بأنينه ( ' ). وعن بَعْض مشايخ الصوفية، أنه كان إذا سافر واحد من أصحابه يقول له إن

$$
\text { رأيت مخزونًا فأقرئه منى السلام . }
$$

يقول الشيخ أبو عَليّ الدقاق: كان بعض الصوفية يقول للشمس عند غروبها:

$$
\text { هل طلعت اليوم على محزون. }
$$

وكان الحسن البصري ( r ) لا يراه أحد إلا ظن أنه حديث عهد بمصيبة،

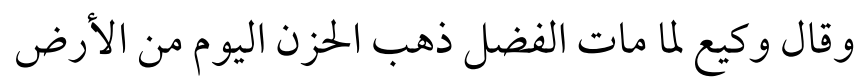

وقال : الفضيل بن عياض ( r ) يقول: كان السلف يقولون إِن على كل شيء

كثيرة مات سنة اثنتين وستين ومائة، وقيل: سنة خمس وستين (سير أعلام النبلاء، جـV

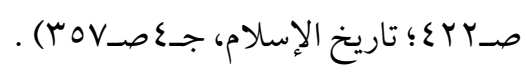

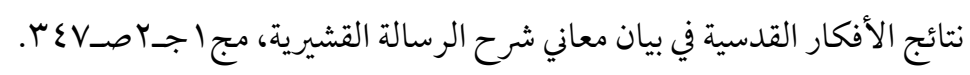

الحسن بن أبى الحسن يسار، أبو سيعد، مولى زيد بن ثابت الأنصاري، نشأ الحسن بو ادي القرى، حضر الجمعة مع عثمان، وسمعه يخطب، وشهد عنه محمد بن سعد:" كان الحسن جامعاً، عالماً،

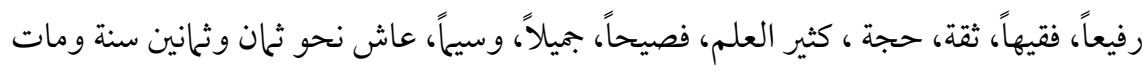

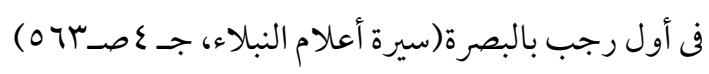

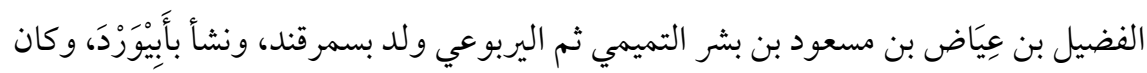
$=$ 


\section{G.}

زكاة وزكاة العقل طول الحزن ( ').

ولقد عرف عن السيدة "رابعة العدوية " دوام حزنها وبكائها، قال الإمام

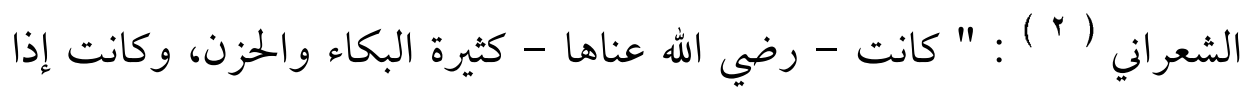

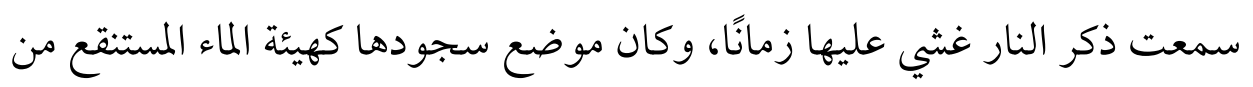

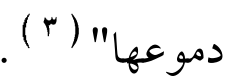

فالسيدة رابعة كما يقول الشيخ مصطفى عبد الرازق وماسينيون ( ؛ ) : "هي

إمامًا، حجة زاهدًا، عابدًا، ربانيًا، قال ابن عيينة والعجلي وغيرهما: فضيل ثقة، وقال أبو حاتم: صدوق، وقال أبو بكر الصوفي :سمعت وكيعًا يقول يوم مات الفضيل: ذهب الحُّن اليوم من

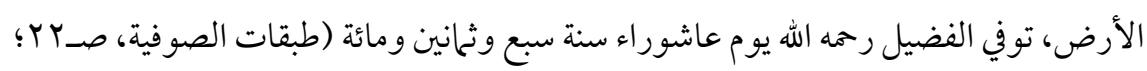

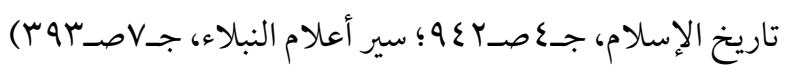

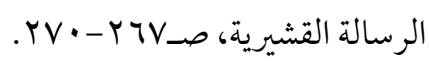

عبد الوهاب بن أحمد بن علي الحنفي نسبة إلى محمد ابن الحنفية، الشعراني، أبو محمد، من علماء المتصوفين، ولد في قلقشندة مصر، ونشأ بساقية أبي شعرة - من قرى المنوفية - وإليها نسبته الشعراني، ويقال: الشعراوي وتوفي في القاهرة سنة ثلاث وسبعين وتسعائة (الأعلام، ونسئ

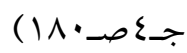
الطبقات الكبرى، الشعراني، جـا صـا 0، كبعة سنة 10 ابا اهـ، المطبعة العامرة، مصر.

لويس ماسينيون، ولد في نوجان إحدى ضواحي باريس لأب نحات للتماثيل، حصل على

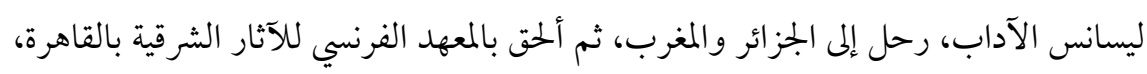

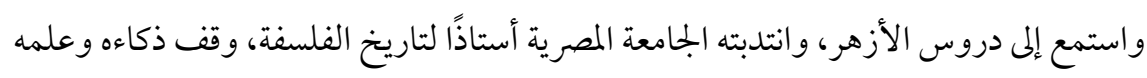
ونشاطه في التنقيب والتعليم والتصنيف على الإسلام: آثارًا ونظمًا اجتماعيه، وفرقًا، ولا سيا

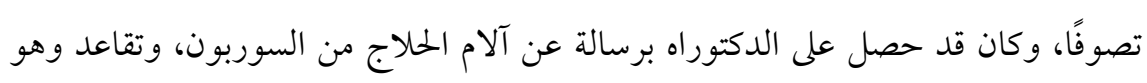
$=$ 


\section{Gen}

السابقة إلى وضع قواعد الحب والحزن في هيكل التصوف الإسلامي، وهي التي تركت في الآثار الباقية نفثات صادقة في التعبير عن محبتها وعن حزنها وإن الذي فاض به الأدب الصوفي بعد ذلك من شعر ونثر في هذين البابين، لهو نفحة من نفحات السيدة رابعة العدوية إمام العاشقين والمحزونين في الإسلام" ( 1 ( ).

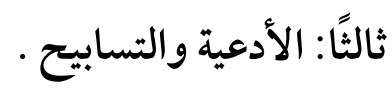

الأدعية من أقوى الأسباب لدفع الحزن والهم، وجلب السعادة والراحة، ذلك أن الداعي يأوي إلى ركن شديد يستعين به،وصدق رسول الله -

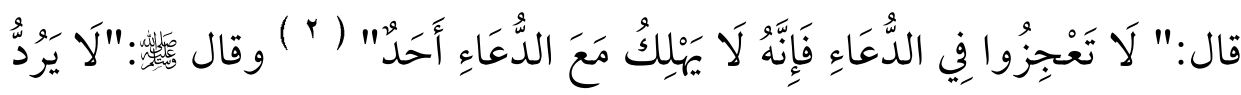

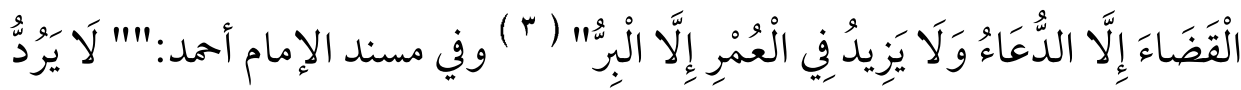

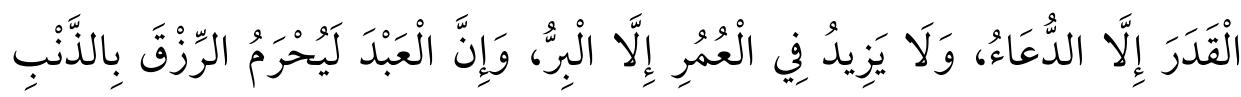

مديرًا للدراسات في المدرسة العملية العليا في باريس، توفي سنة اثنين وستين وتسعائة وألف من

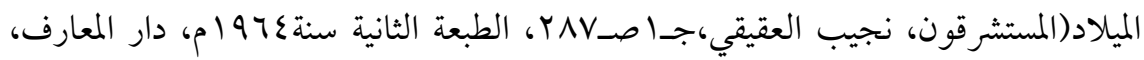
مصر

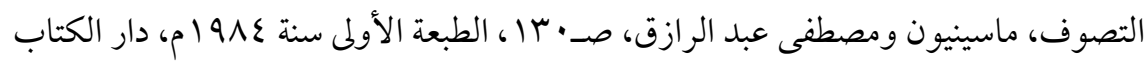

$$
\text { اللبناني، بيروت - لبنان. }
$$

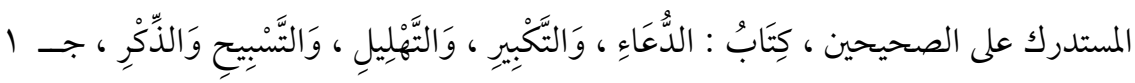
. TVI ص

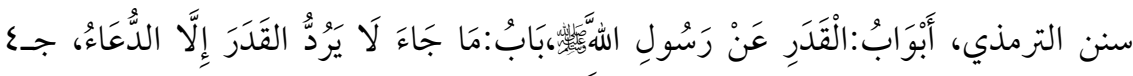

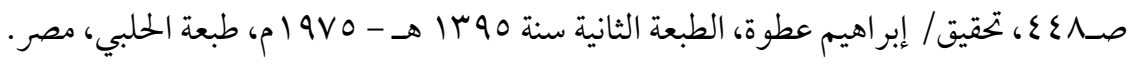




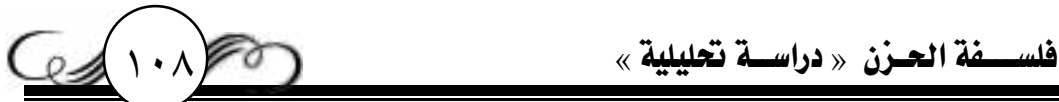

يُصِيبهُ" ( 1 ) كما أن الدعاء وسيلة لتنزل الرحمات، فمن أدركته رحمة الله فقد سعد

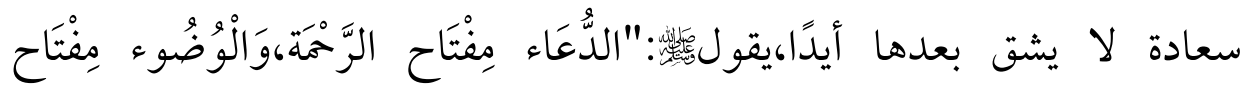

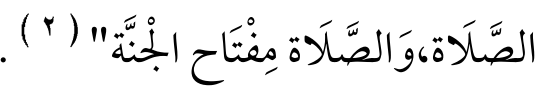

وحديث النبي

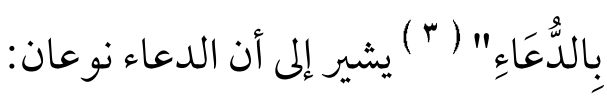

النوع الأول:علاجي وهو ما أشار إليه النبي نَزَََ"وهو الموجود المستقر، ونفعه يتأتى من وجهتين:

الأولى : إما رفعه إن كان مُعَلَّقًا، و الثانية: بالصبر إن كان عحمحًَا، فيسهل عليه تحمل ما نزل به من بلاء فَيُصَبِّه عليه، أو يرضه به حتى لا يكون في نزوله متمنيًا خلاف ما كان،بل يتلذذ بالبلاء كما يتلذذ أهل الدنيا بالنعماء.

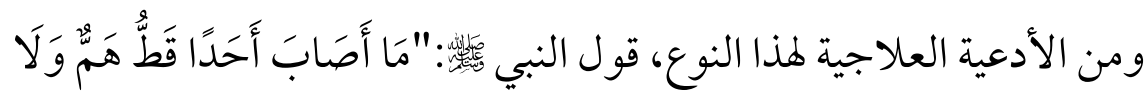

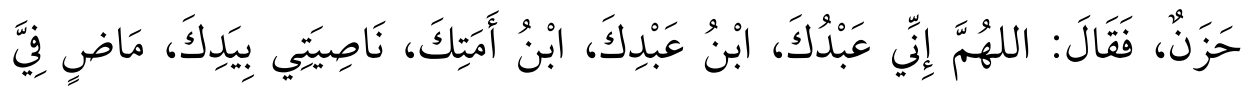

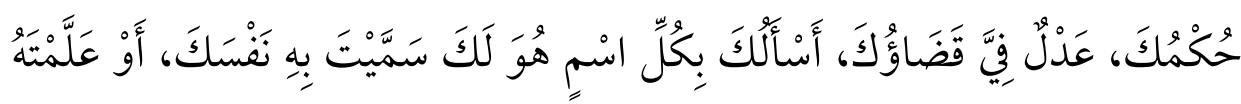

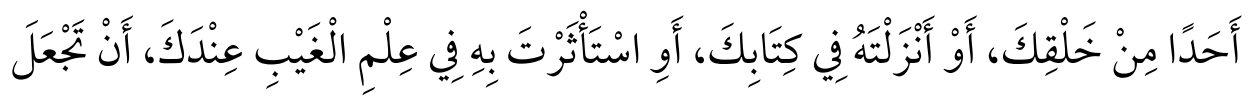

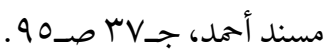

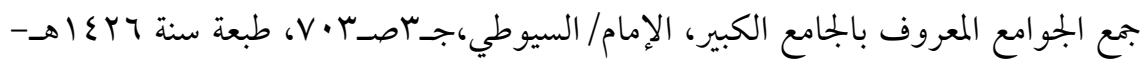

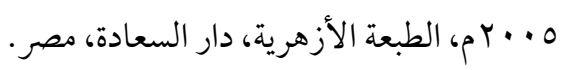

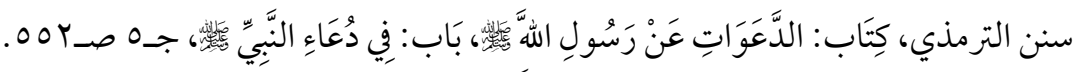


G.

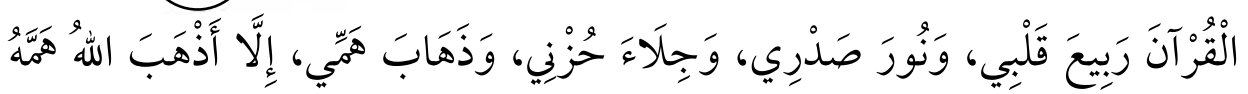

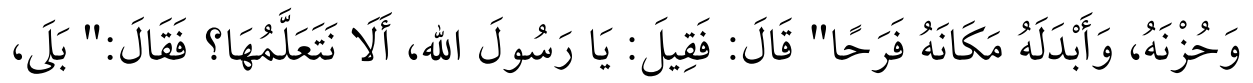

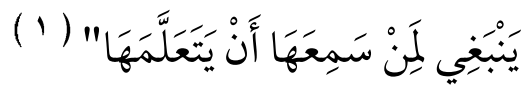

ومن هذا النوع قول النبي

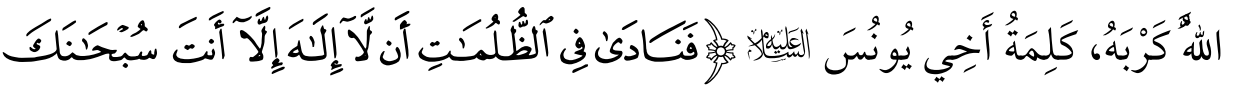

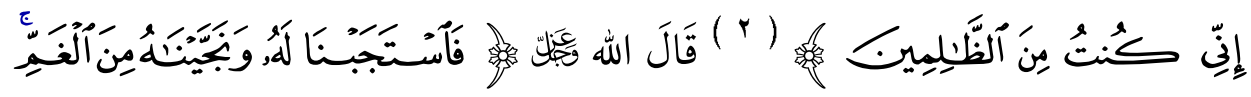

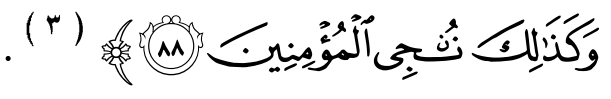

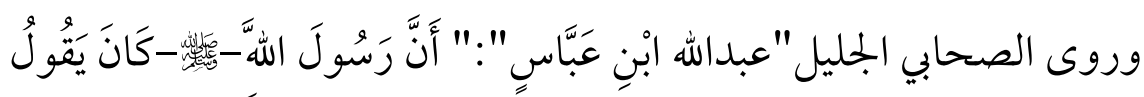

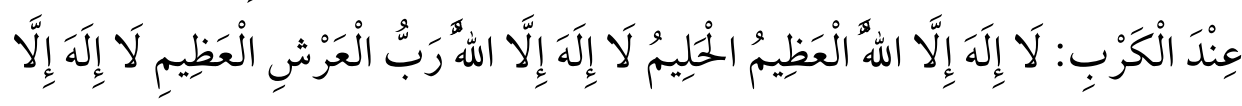

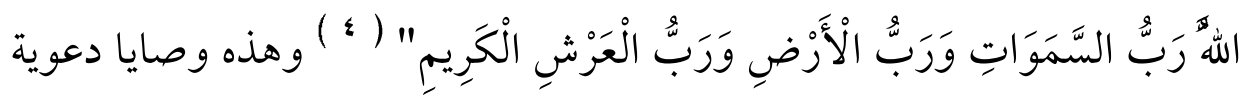
نبوية نافعة في إزالة الحزن، والشفاء من الهم والغم بأمر الله بَّلآلَ.

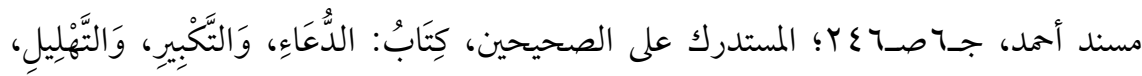

$$
\begin{aligned}
& \text { وَالتَّنبِيحِ، جـاصـ. } 79 . \\
& \text { سورة الأنبياء، الآية:NV. } \\
& \text { سورة الأنبياء، الآية: 11. }
\end{aligned}
$$

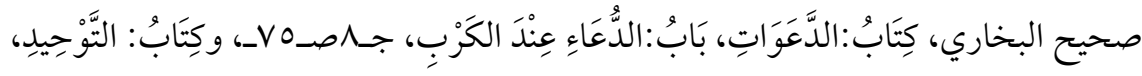

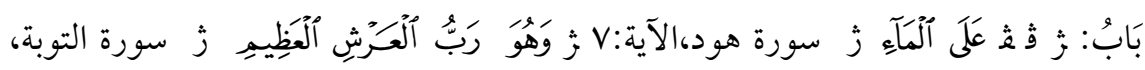

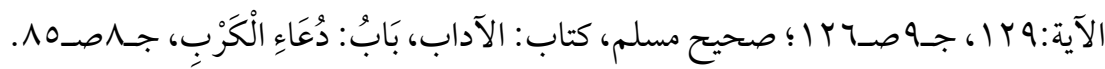




\section{Gen}

وهذه الأدعية محض توحيد؛ ومن نفحاتها إزالة الأمراض النفسية على وجه

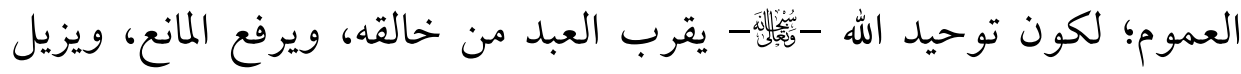
الحجاب الذي يحجب القلب عن الوصول إليه، فإذا وصل القلب إليه زال عنه همه وغمه وحزنه، وإذا انقطع عنه حضرته الهموم والغموم والأحزان، وأتته من كل طريق، ودخلت عليه من كل باب.

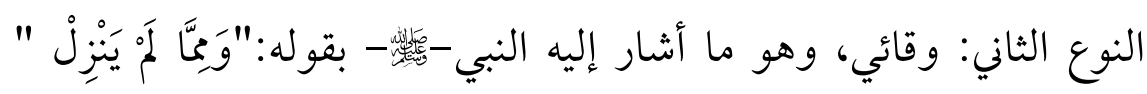

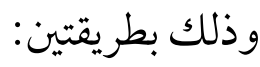
الأولى : صرف البلاء ودفعه عن المرء.

الثانية: تأييد الإنسان وتقويته بإمداده بما يخفف معه أعباء ذلك إذا نزل به. ومن الأدعيـة الوقائيـة من الحـزن، ما رواه الصحـابي الجليـل " أنس بن

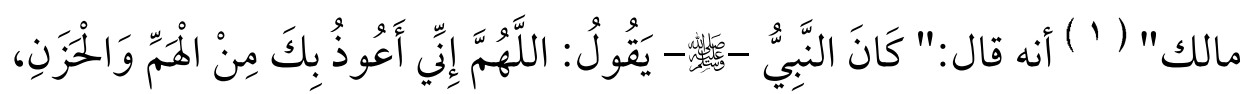

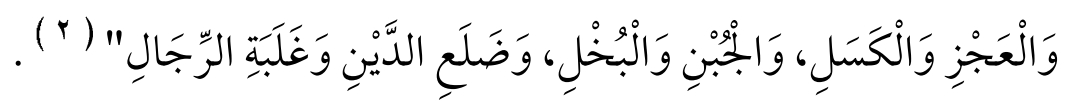

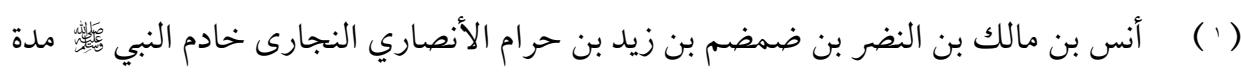

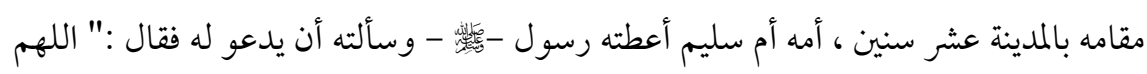
أكثر ماله وولده ،وأطل عمره، وادخله الجنة " فاستجاب الله دعاءه ـ كانت وفاته بالبصرة وهو الها آخر من كان قد بقى فيها من الصحابة وذلك فى سنة تسعين(البداية والنهاية

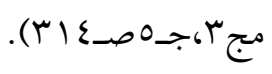

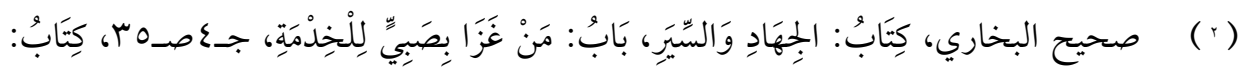
$=$ 


\section{G.ing}

هذاالدعاءمن جوامع الكلم؛ لأن أنواع الرذائل ثلاثة: نفسانية وبدنية وخارجية، فالأولى بحسب القوى التي للإنسان وهي ثلاثة: العقلية والغضبية والشهوانية، فالهم والحزن يتعلق بالعقلية، والجمبن بالغضبية والبخل بالشهوانية،

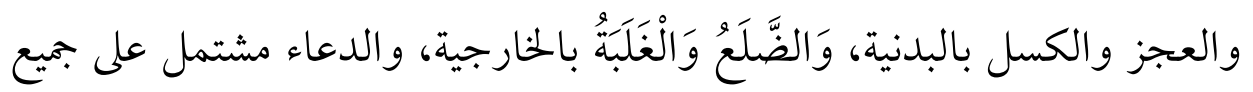
ذلك (1)

ومن الآيات التي تصف الطبيعة البشرية وما يعتريها من آلام وأحزان وفيها

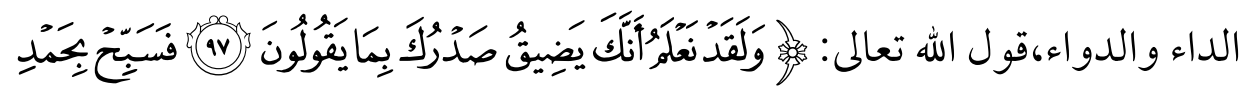

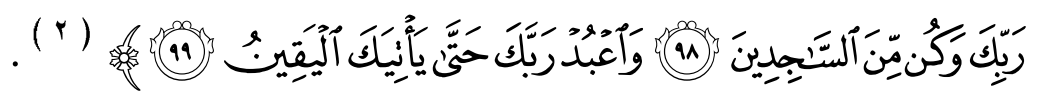
لما ذكر أن قومه يُسَفِّهُونَ عليه ولا سيا أولئك المقتسمون وأولئك المستهزئون قال له:ولقد نعلم أنك يضيق صدرك بها يقولون؛لأن الجبلة البشرية والمزاج

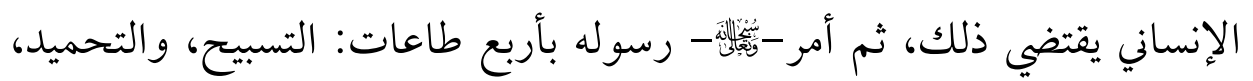
والسجود، والعبادة، ففي أدائهن العلاج النافع. والسؤال الذي يطرح نفسه، كيف صار الإقبال على هذه الطاعات سببًا

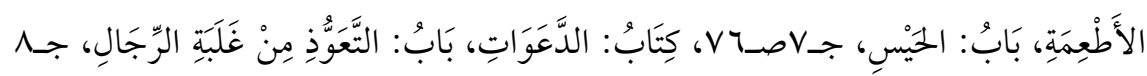
. V9، $\vee \wedge$ ص

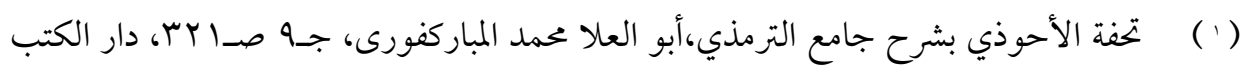

$$
\text { سورة الحجر، الآية:9V، 91، 91، 99. }
$$




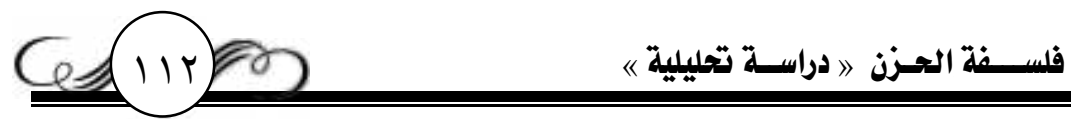

لزوال ضيق الصدر والحزن؟ ذلك لأن الإنسان إذا اشتغل بهذه الأنواع من العبادات انكشفت له أضواء عالم الربوبية، ومتى حصل ذلك الانكشاف صارت الدنيا بالكلية حقيرة، وإذا صارت حقيرة خف على القلب فقدانها ووجدانها فلا يستو حش من فقدانها ولا يستريح بو جدانها، وعند ذلك يزول الحزن و الغم.

وقالت المعتزلة: من اعتقد تنزيه الله -تعالى- عن القبائح سهل عليه تحمل المشاق، فإنه يعلم أنه عدل منزه عن إنز ال المشاق به من غير غرض ولا فائدة فحينئ

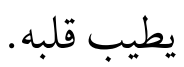

وقال أهل السنة: إذا نزل بالعبد بعض المكاره فزع إلى الطاعات كأنه يقول:

$$
\text { تجب علي عبادتك سو اء أعطينني الخيرات أو ألقيتني في المكروهات ( } 1 \text { ) . }
$$

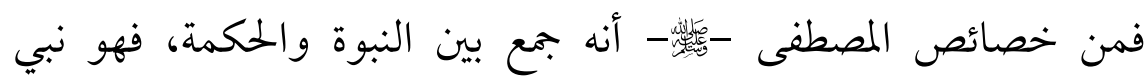

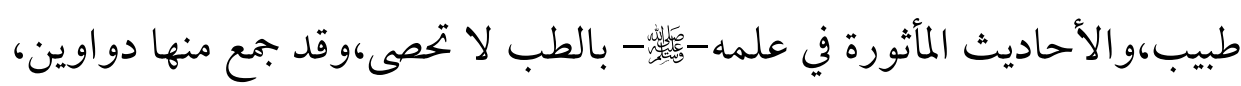
واختلف في مبدأ هذا العلم على أقوال كثيرة، والمختار أن بعضه علم بالوحي،

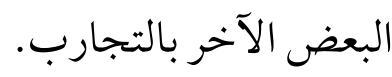

ولقد علم النبي

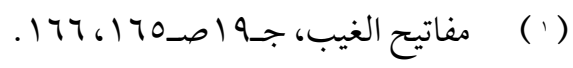

(r) هشام بن عروة بن الزبير بن العوام القرشي الاسدي، أبو المنذر، وقيل: أبو عبد الله، المدني له $=$ 


\section{Genes}

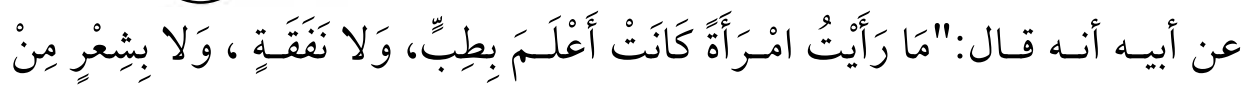

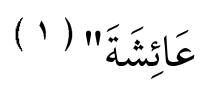

ولقد روت كتب السنة الصحاح، كثير من النصائح والإرشادات الطبية النبوية التي يصف فيها النبي حتى إن العلم الحديث بتقنياته المتقدمة، أشاد بنتائج ما جاء في هذه الأحاديث النبوية، وأصبح التداوي بالأغذية اليوم مطلب عالمي .

جاء في "المواهب اللدنية بالمنح المحمدية"أنه-الأطعمة وطبائعها واستع|لها على قاعدة الطب، فإذا كان في أحد الطعامين ما يحتاج إلى كسر وتعديل،كسره وعدله بضده إن أمكن، كتعديله حرارة الرطب بالبطيخ، وهذا أصل كبير في المركبات من الأدوية، وإن لم يجد ذلك، تناوله على حاجة وداعية

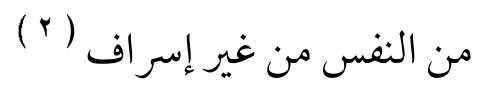

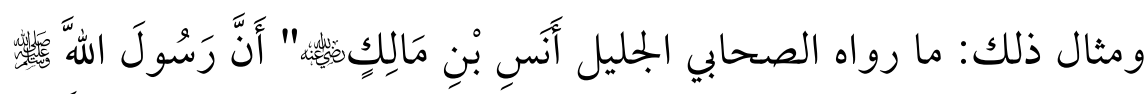

نحو أربع مائة حديث، وقال عممد بن سعد والعجلي: كان ثقة، زاد ابن سعد: ثبتًا، كثير

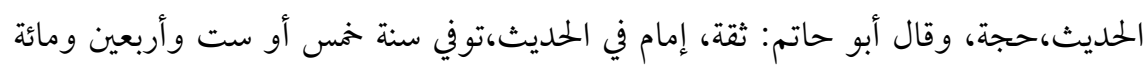

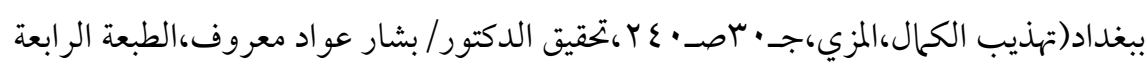

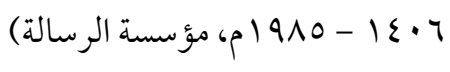

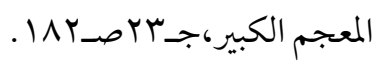

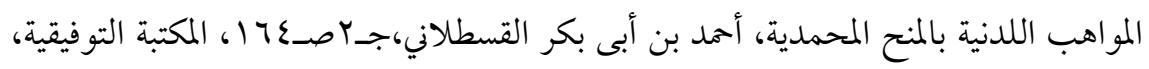

$$
\text { القاهرة - مصر. }
$$




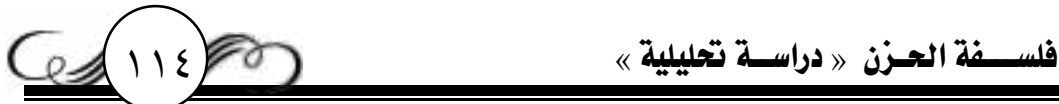

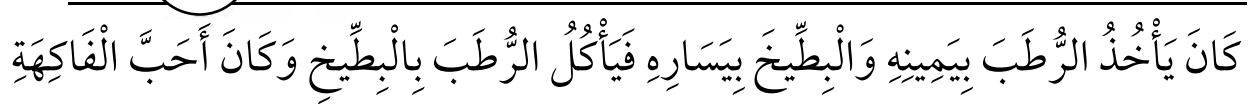

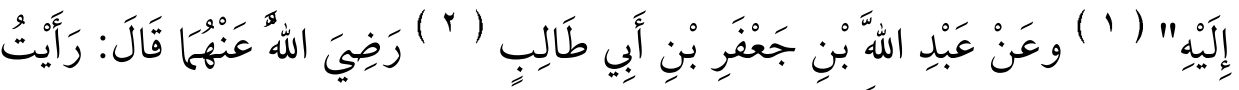

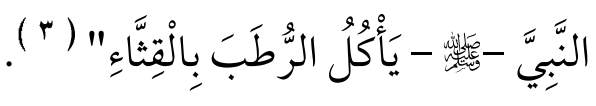

وقال الإمام القرطبي ( ؛ ) في تعليقه على هذا الحديث وأمثاله:"وفيه دليل على جواز مراعاة جو صفات الأطعمة، وطبائعها،واستعهالها على الوجه الأليق بها،كا يقوله الأطباء؛لأن في الطب حرارة وفي الْقِثَّاء برودة،فإذا أكالا معًا اعتدلا،وهذا

$$
\text { أَصل كبير في المركبات من الأدوية" ( • ) . }
$$

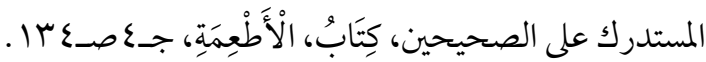

عبد الله بن جعفر - ذي الجناحين- بن أبي طالب بن عبد المطلب بن هاشم بن عبد مناف،

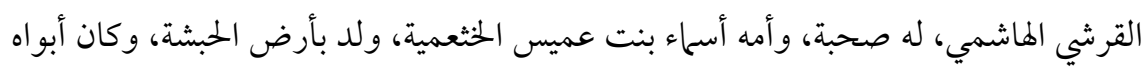
رضي الله عنها هاجرا إليها، فولد هناك، وهو أول مولود ولد في الإسلام بأرض الحبشة، وقدم مع أبيه المدينة، وهو أخو محمد بن أبي بكر الصديق، ويميى بن علي بن أبي طالب رضي الله عنهم

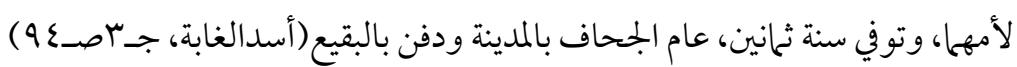

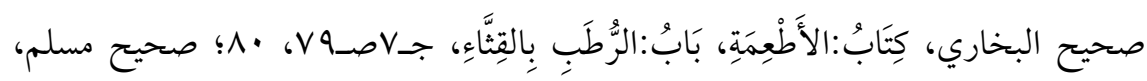

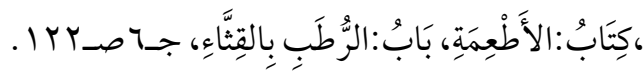
أحمد بن عمر بن إبراهيم بن عمر أبو العباس الأنصاري القرطبي المالكي الفقيه المحدث المدرس بالإسكندرية ولد بقرطبة سنة ثمان وسبعين وخمسمائة وسمع الكثير هناك، واختصر الصحيحين، وشرح صحيح مسلم المسمى بالمفهم، وفيه أشياء حسنة ، توفى سنة ست وخمسين وستمائة

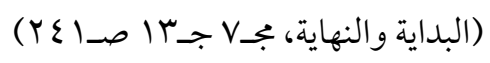

المفهم لما أشكل من تلخيص كتاب مسلم، أبو العباس أحمد بن عمر الأنصاري، جـ اصـه • ج، $=$ 


\section{Cosio}

وعنون له أبو نعيم ( 1 ) في كتابه الطب النبوي بقوله :"باب: يذكر فيه

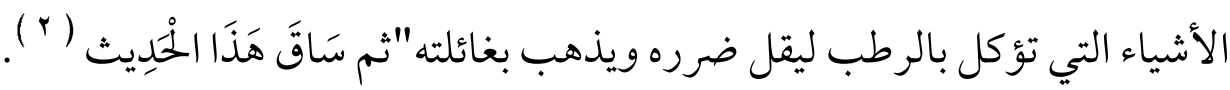

وفي الأحكام النبوية: أن النبي - -

ومرضه، أما في صحته: فاستعمال التدبير الحافظ لها من الرياضة وقلة المثناول، وأكل

الرطب بالقثاء، والرطب بالبطيخ، ويقول: يدفع حر هذا برد هذا، وإكحال عينيه

بالإثمد، كل ليلة عند النوم، وتأخير صلاة الظهر في زمن الحر القوي، ويقول: أبردوا بها، وأما تداويه في حال مرضه، فثثابت بما روي من ذلك في الأخبار

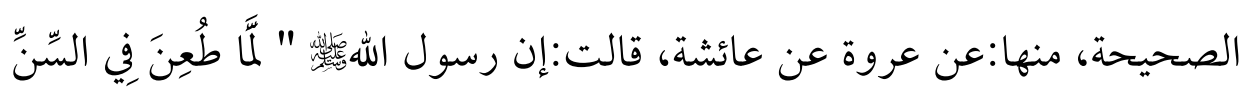

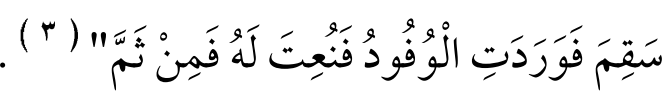

ومما ورد عن النبي-

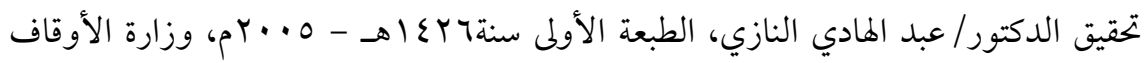

$$
\text { والشئون الإسلامية، الرباط - المغرب. }
$$

هو أمد بن عبد الله بن أحمد بن إسحاق بن مهران، أبو نعيم الأصبهاني الصوفي الأحول، ولد الصاط

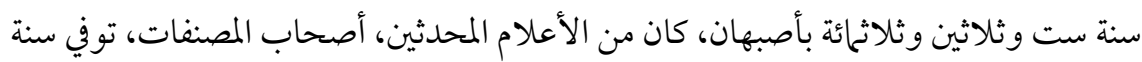

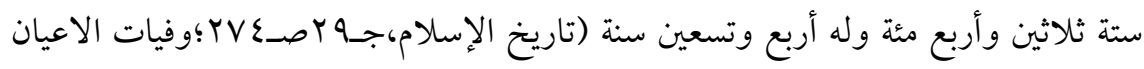

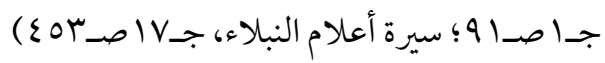

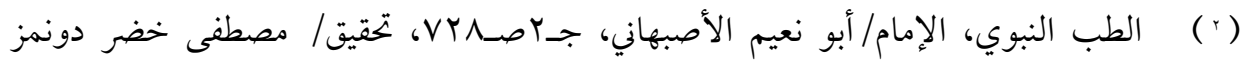

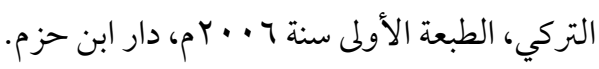

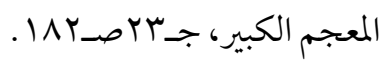




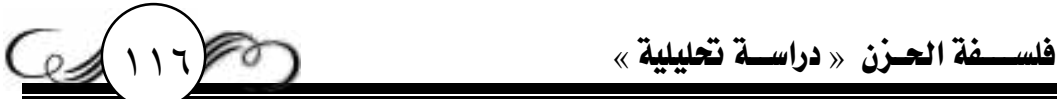

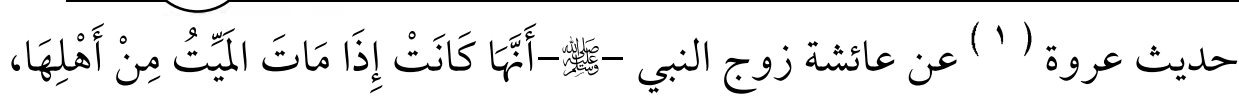

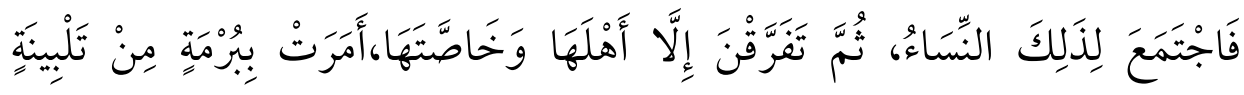

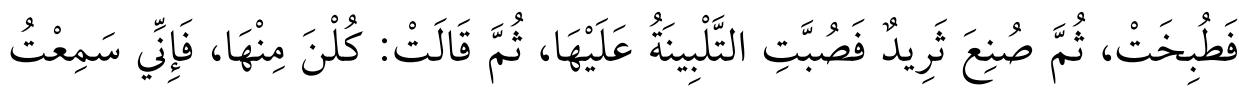

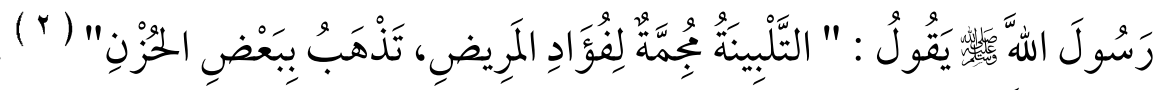

وروى الإمام البخاري ( ب ) رحه الله،عن السيدة عائشة رضي الله عنها:أَنََّّا

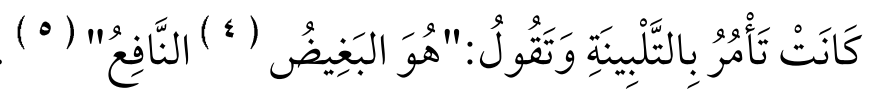
وروى الإمام الحاكم ( ") رحمه الله، عن السيدة عائشة - رضي الله عنها- أنها

عروة بن الزبير بن العوام القرشي الأسدي أبو عبد الله تابعي جليل، كان ثقة كثير الحديث عالماً ( ')

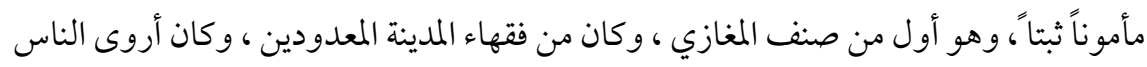

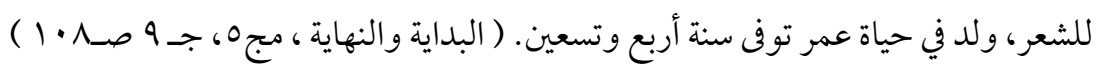

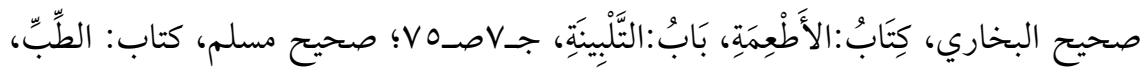

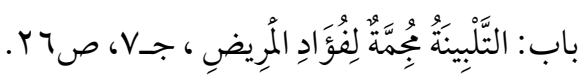

محمد بن إسماعيل بن إبراهيم بن المغيرة البخاري، ولد سنة أربع وتهيع وتسعين ومائة من الهجرة في

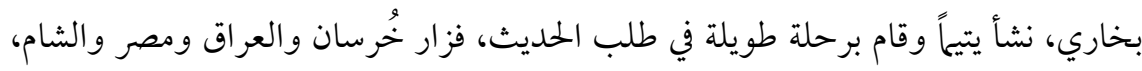

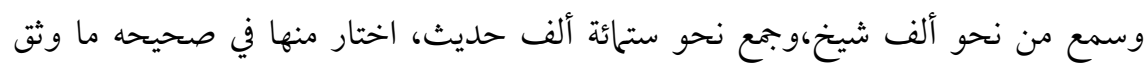
بروايته، توفى ليلة السبت بعد صلاة العشاء، وكان ليلة عيد الفطر، ودفن يوم الفطر بعد صلاة

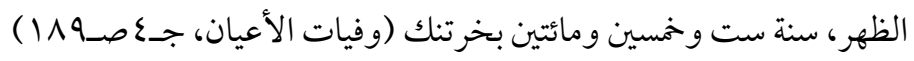

$$
\text { وسمي الْبَغِيضَ النافع لأن المريض يَعَافُهُوهو نافع له. }
$$

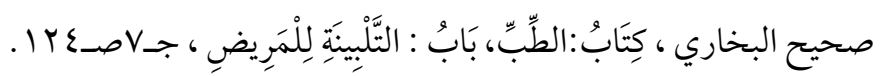

الحاكم بن البيع النيسابوري، أبوعبد الله محمد بن عبداله بن محمد بن حمراويه بن نعيم بن الحكم $=$ 


\section{Q⿻}

قالت: قال رسول الله

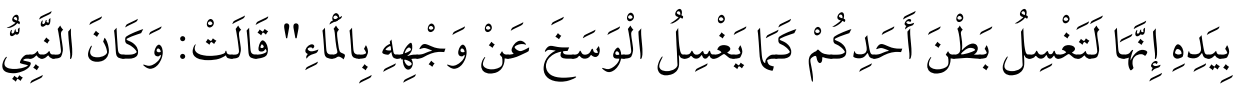

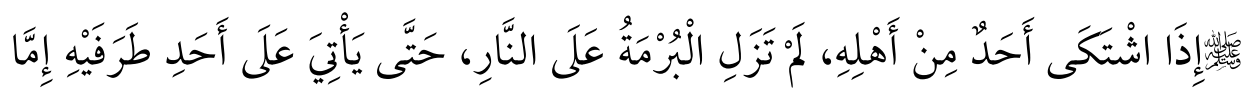

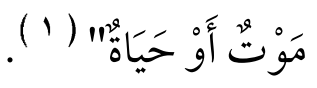

والتَّبِينَة: بفتح المثناة وسكون اللام وكسر الموحدة، بعدها تحتانية ثم نون

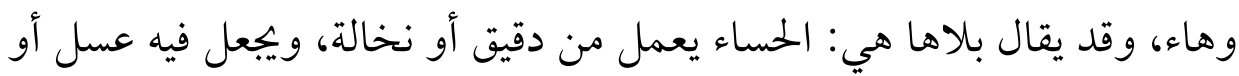

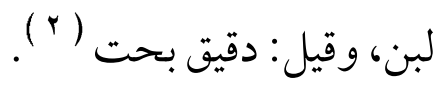

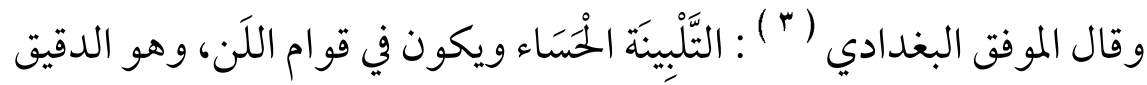

الضبي الطهاني، المعروف بالحاكم النيسابوري، ولد في شهر ربيع الأولى سنة إحدى وعشرين وثلاثة مائة بنيسابور، إمام أهل الحديث في عصره، والمؤلف فيه من الكتب التي لم يسبق إلى

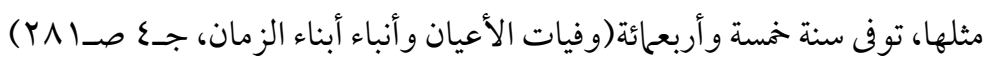

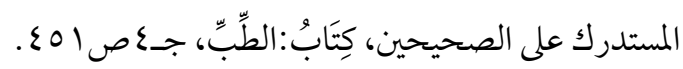

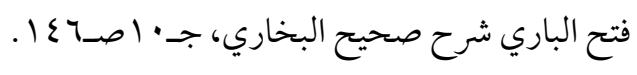

عبد اللطيف بن يوسف بن محمد بن سعد،العلامة موفق الدين البغدادي الشافعي النحوي اللغوي المتكلم الطبيب الفيلسوف المعروف بابن اللباد، ولد ببغداد سنة خمس وخمسين وخمسمائة،وحدث بمصر والقدس ودمشق وحران وبغداد، وكان أحد الأذكياء المضلعين من الآداب والطب وعلم الأوائل، توفي ببغداد سنة تسع وعشرين وستمائة(فوات الوفيات، محمد

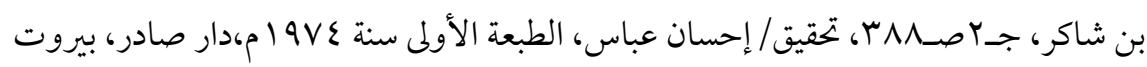


النضيج لا الغليظ النّيء (1).

وسميت تلبينة: لشبها باللبن لبياضها ورقتها، وقال الإمام/ ابن القيم:"

وهذا الغذاء هو النافع للعليل، وهو الرّقيق النضيح لا الغليظ النّيّهُ، وإذا شئت أن تعرف فضل التَّلْبينةِِ فاعرف فضل ماء الشعير، بل هي ماء الشعير هم، فإنها حساء متخذ من دقيق الشعير بنخالته، والفرق بينها وبين ماء الشعير أنه يطبخ صحاحًا، وَالتَّنبينَةُ تطبخ منه مطحونًا، وهي أنفع منه لخروج خاصية الشعير بالطحن" ( r ) . وقول النبي

وكسر الجيم، أي تريح فؤاده، وتزيل عنه الهم وتنشطه، والجمام المستريح (" ).

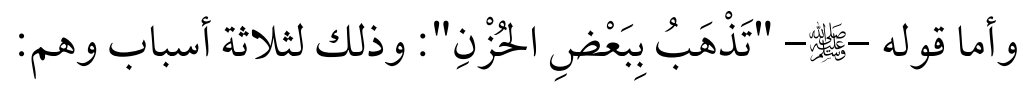

الأول : لأن الغم والحزن يبردان المزاج، ويضعفان الحرارة الغريزية؛ لميل الروح الحامل إلى جهة القلب الذي هو منشأها، وهذا الحساء يقوى الحرارة الغريزية بزيادة مادتها، فتزيل أكثر ما عرض له من الغم والحزن.

( ) الطب من الكتاب و السنة، موفق الدين البغدادي، صـ191 ، تحقيق الدكتور/ عبد المعطي أمين قلعجي، الطبعة الثالثة سنة ا ع (اهـ - ع 99 (م) دار المعرفة، بيروت لبنان.

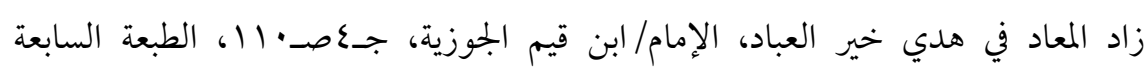
و العشرون سنة 1 ع ( هـ-ـع 99 1 م، مؤسسة الرسالة، بيروت، مكتبة المنار الإسلامية، الكويت.

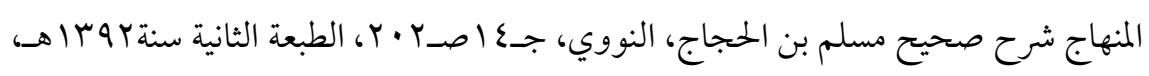

$$
\text { دار إحياء التراث العربي، بيروت-لبنان. }
$$




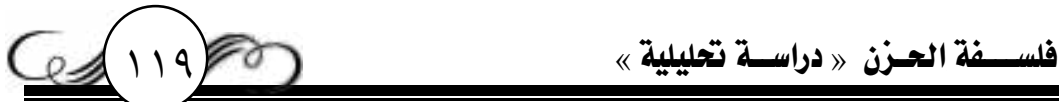

الثاني: إنها تذهب ببعض الحزن، بخاصية فيها من جنس خواص الأغذية المفرحة ، فإن من الأغذية ما يفرح بالخاصية.

الثالث: إن قوى الحزين، تضعف باستيلاء اليّبه على أعضائه، وعلى معدته خاصة؛ لتقليل الغذاء، وهذا الحساء يرطبها، ويقويها، ويغذيها، ويفعل مثل ذلك بفؤاد المريض، لكن المريض كثيرًا ما يجتمع في معدته خلط مراري أو بلغمي أو صديدي، وهذا الحساء يجلو ذلك عن المعدة، ويسروه ويحدره ويميعه ويعدل كيفيته ويكسر سورته فيريكها ( وهذا التفسير القيم، هو ما توصل إليه العلم الحديث، وأظهرته التقارير العلمية والمعملية، التي أثبتت وجود عناصر في الشعير تلعب دورًا هامًا في القضاء على الحزن و الاكتئاب، وهذه المواد هي: 1 - المعادن: فتشير الدراسات العلمية إلى أن المعادن مثل البوتاسيوم والماغنسيوم لما تأثير على الموصلات العصبية التي تساعد على التخفيف من حالات الاكتئاب، وفي حالة نقص البوتاسيوم يزداد شعور الإنسان بالاكتئاب والحزن، ويجعله سريع الغضب والانفعال والعصبية، وحيث إن حبة الشعير تحتوي على عنصري البوتاسيوم والماغنسيوم فالتلبينة تصلح لعلاج الاكتئاب، ويلاحظ هنا أن الدراسات العلمية تستخدم كلمة "التخفيف من حالات الاكتئاب" ونجد ما يقابلها في حديث رسول الهه:"تذهب ببعض الحزن" وهذه دلالة واضحة على دقة

$$
\text { زاد المعاد في هدي خير العباد، جــصـ• } 11 .
$$




$$
\text { التعبير النبوي الذي أوتي جو امع الكلم. }
$$

r - فيتامين " B " ": فقد يكون أحد مسببات أعراض الاكتئاب هو التأخر

في العملية الفسيولوجية لتوصيل نبضات الأعصاب الكهربية، وهذا بسبب نقص فيتامين "B"؛ لذلك ينصح مريض الاكتئاب بزيادة الكمية المأخوذة من بعض المنتجات التي تحتوي على هذا الفيتامين كالشعير.

r - مضادات الأكسدة: حيث يساعد إعطاء جرعات مكثفة من حساء التلبينة الغنية بمضادات الأكسدة (فيتامين E وA) في شفاء حالات الاكتئاب لدى المسنين في فترة زمنية قصيرة تتراوح من شهر إلى شهرين. ع - الأحماض الأمينية: يحتوي الشعير على الحمض الأميني تريبتوفان الذي يسهم في التخليق الحيوي لإحدى الناقلات العصبية وهي Tryptophan السيروتونين Serotonin التي تؤثر بشكل بارز في الحالة النفسية والمزاجية الإنسان (1) (1)

نستطيع أن نقول: إن تناول الشعير يعني تناول كميات كبيرة من الأمحاض الأمينية الأساسية التي تصنع منها النواقل العصبية، فيزداد اصطناع النواقل العصبية بشكل طبيعي كبي وتعود وترتفع بعد أن كانت منخفضة بشدة فينتقل المصاب بالحزن من الطاقات السلبية من حزن وهم وغم واكتئاب وتعب وتنقله إلى حالة من الفرح والسرور والاطمئنان والراحة، فالتلبينة تريح القلب الحزين 
وتسكن آلامه النفسية.

تعقيب: نظرية الكندي في علاج الحزن.

إن الكندي ينصح بمحاولة اكتساب النفس الخصال الحميدة على

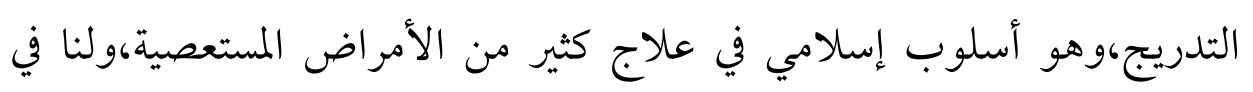
الخلاص من الخمر خير دليل وشاهد على نجاح هذه الطريقة .

وهذا الفيلسوف يري أن نبدأ بتعويد النفس المحامد السهلة البسيطة،ثم يأتي بعد ذلك الخصال الحميدة في الأمور الأصعب، ونستمر في هذا التدرج حتى تكتسب النفس من الصفات الحميدة ما هو أصعبها وأشدها وأعلاها،إذ يقول في ذلك:"إصلاح النفس إنها هو بقوة العزم على المصلح لنا، لا بدواء مشروب، ولا بألم

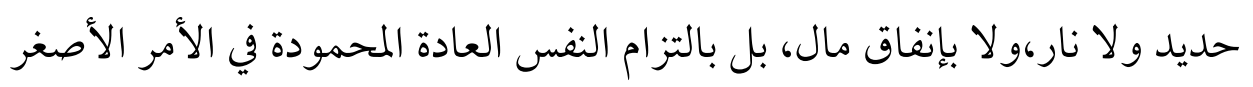
الذي لزومه سهل عليناءثم نرتفع من ذلك إلى لزوم ما هو أكبر منه، فإذا اعتادت ذلك نرقي بها إلى ما هو أكبر من ذلك في درج متصلة حتى نلزمها العادة في لزوم

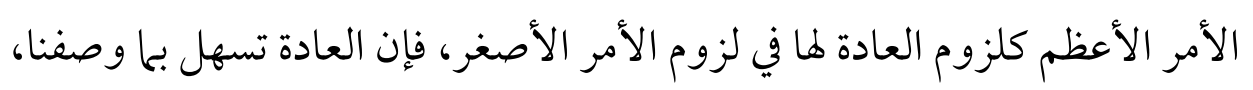
ويسهل بذلك الصبر على الفانيات والسلوة على المفقودات" ( ' ). ثم يبدأ الكندي في ذكر الأساليب والطرق التي يدفع بها الأحزان وهي: -

رسالة الكندي " في الحيلة لدفع الحزن " ضمن رسائل فلسفية تحقيق/عبد الرمن بدوي، ص 


\section{فلســفة الحـزن 》 دراسـة تحليلية 《)}

الأول : حزن يرجع إلى أنفسنا، ويتوقف أمره على إرادتنا؛ لكونه فعل نقوم

به. الثاني: حزن يرجع إلى إرادة الغير؛ لكونه محصلة فعل يقوم به، فأما الأول فبامكاننا التخلص منه بسهولة ويسر، عن طريق التخلي عن هذا الفعل المحزن وتجنبه .

و أما الثاني: فإما أن نستطيع التوقي منه أو لا نستطيع، فإن استطعنا فلنحتمي منه حتى لا يسبب لنا الأحزان،وإن لم نستطع، فليس من حقنا وينبغي أن لا نحزن قبل وقوع وحدوث الفعل؛ لأنه ربها تخلف الفعل ولم يقع، فإذا وقع الفعل وأدى إلى حزننا، فمن الواجب علينا. r - يجب أن نتذكر ما وقع لنا في الماضي ولغيرنا من أحداث محزنه، وما آلت إليه من السلوة والنسيان؛ فهذا يهون علينا وطئة الشعور الحاضر، ويمدنا بقوة على الصبر و السلو ان عما نلاقيه ( 1 ( ) r - ليس كل شيء ينبغي أن نحزن عليه؛ لأن جميع الأغراض المشتركة بين الجميع ويمكننا الحصول عليها، لسنا بأحق بها من غيرنا، وغالبًا الأسبق هو من له الغلبة في الحصول عليها، أما ما يخصنا،ولا يشاركنا فيه أحد، و لا يملكه غيرنا،فهي الخبرات النفسية" فهذه هي التي لنا العذر في الحزن عليها إن فقدناها من أنفسنا،فأما ما ليس لنا إلا بالتغلب فليس يحسن بنا الحزن عليه؛ لأن من حزن على أن لا يملك الناس ما لمم أن يملكوه بالطبع فهو حسود فينبغي لنا أن لا نعرف

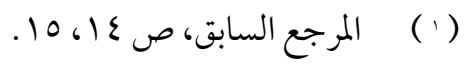




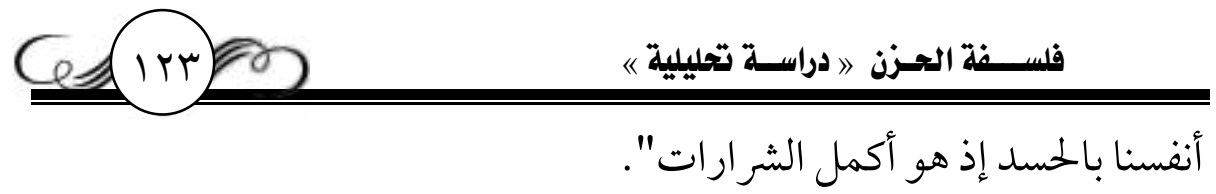

ع - ومما يجب أن نتذكره و لا يغيب عن خاطرنا، أن كل ما نملكه إنها هو

عارية لمعير هو الله -جل ثناؤه- ومن حقه أن يسترد عاريته متى شاء،ولا يحق لنا أن نحزن متى استردت هذه الأمانة، وينبغي أن لانأسى على فقد ما ارتجع منا، بل يجب

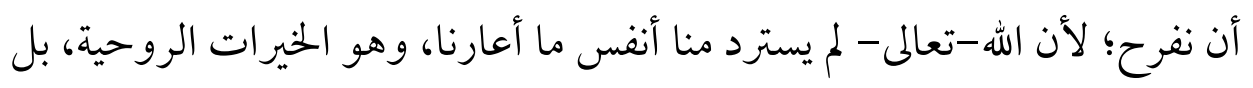
استرد الأقل الأخس، وهو ما نمتلكه من الأمور الدنيوية الفانية الخارجة عنا، وهذا

$$
\text { ينبئ عن تكريمه لنا وإيثاره إيانا ( ' ). }
$$

0 - ينبغي أن يكون منا على بال أنه إن كان واجب أن نحزن على المفقودات و

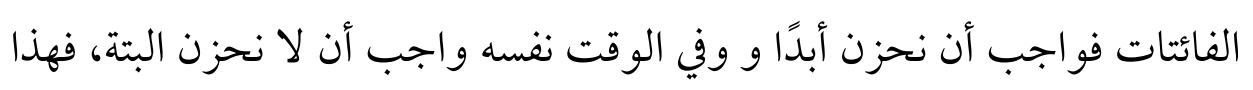
تناقض فاحش؛ لأنه إن كان علة الحزن فقد القنيات الخارجة عنا، فإنه إذا لم تكن لنا

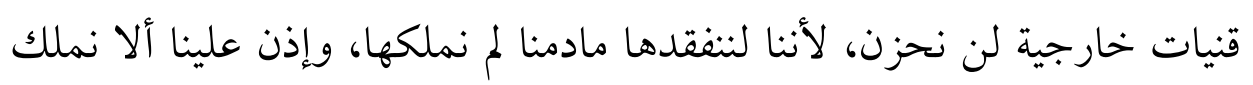
شيئًا حتى لا نفقده في كون فقدانه مسببًا للحزن . 7 - علينا أن نتذكر أن الله لم يخلق مخلوقًا دون أن يزوده بها يحتاج إليه، إلا الإنسان؛ لأنه وقد زود بالقوة التي بها يسيطر على الحيوان ويحكمه ويوجهه، فإنه

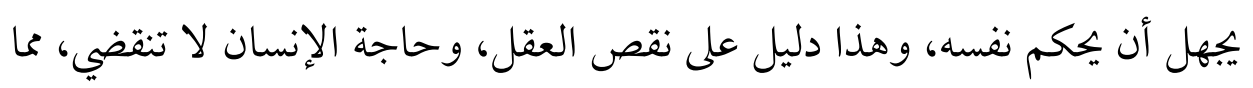

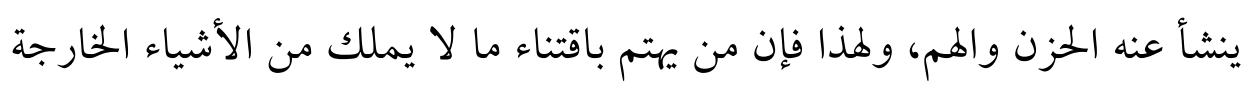
عنه لا تنقضي غمومه وأحزانه.

(') المرجع السابق، صـ1V،IN. 


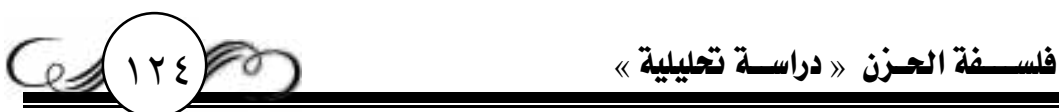

وحال الناس في عبورهم في هذا العالم الفاني حال خداعة، تشبه حال أشخاص أبحروا في سفينة إلى مكان هو مقامهم، فاقتادهم الملاح إلى مرفأ ألقى فيه مرساته للتزود بالمؤونة، وخرج الركاب للتزود ببعض الحاجات، فبعضهم اشترى ما يحتاج إليه وعاد إلى السفينة، وشغل مكانًا مريخًا فيها، والبعض الآخر لبثوا لمشاهدة المروج ذات الأزهار اليافعة والروائح الطيبة، ووقفوا يستمعون إلى الأطيار، ثم لم يجاوزوا مكانًا قريبًا من السفينة، ثم عادوا إليها بعد أن أشبعوا حاجاتهم، فو جدوا أيضًا أماكن مريجة فيها، وفريق ثالث انصرف إلى جمع الأصداف والأحجار، وعادوا مثقلين بها، فلم) عادوا إلى السفينة وجدوا من سبقوهم قد احتلوا الأماكن المريحة، فاضطروا إلى شغل أماكن ضيقة، واهتموا بالمحافظة على الأحجار والأصداف التي جمعوها، مما أوقع الهم في نفوسهم، وفريق رابع وأخير توغلوا في المروج والغابات، ناسين سفينتهم ووطنهم، وانهمكوا في جمع الأحجار والأصداف والأزهار، ونسوا وطنهم والمكان الضيق الذي ينتظرهم في السفينة، ونادى الملاح على المسافرين، فلم يستطع هذا الفريق الأخير سماع ندائه، ورفع المرساة تاركًا إياهم معرضين للأخطار القاتلة: فبعضهم التهمته الوحوش الكاسرة، و البعض غار في الهوّيّ، وساخ بعضهم في الطين، ويعضهم عضته الأفاعي، وهكذا صاروا جيفا نتنة .

وهذا المثل ينطبق على حالنا في هذه الدنيا، فعلينا ألا نشغل بما يؤدي إلى الأحزان من جمع القنيات والانعكاف على الشهوات، حتى نستطيع أن نجد مكانًا فسيحًا في السفينة التي ستقلنا إلى الوطن الحق، وهو الآخرة أو ما يطلق عليه 


\section{G}

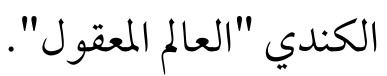

V - ينغي علينا ألا نكره ما ليس رديثًا، وأن نكره ما هو رديء، فهذا من

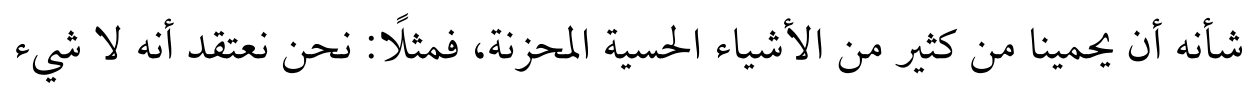

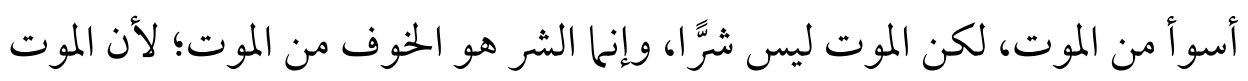
تمام لطبيعتنا، ويدون الموت، لن يوجد إنسان أبدًا؛ لأن تعريف الإنسان هو أنه حيوان عاقل فلو لم يكن موت ، لم يكن إنسان، لأنه إن لم يمت، لم يكن إنسانًا، ولخرج عن طبيعة الإنسان، والأمر السيئ هو ألا نكون ما نحن إياه، وبالتالي الشيء السيىء هو ألا نموت، وإذن فالموت ليس بشر، يقول الكندي:" ينبغي أن يكون منا

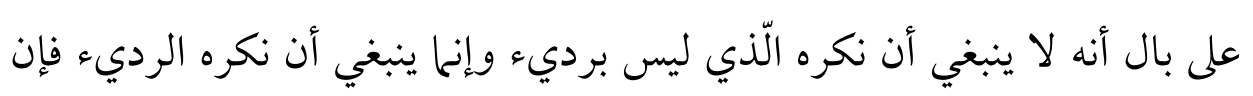

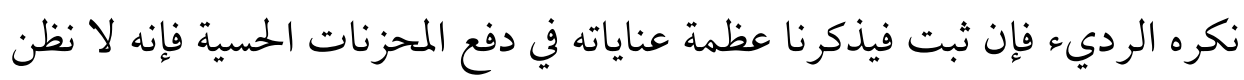
أن شيئا أردا من الموت و الموت ليس برديء إنما خوف الموت رديء فما الموت فهو

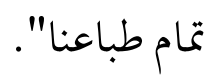

1 - ومما يدفع الحزن عن الإنسان، تعديد ما بقى له من خيرات ومتلكات ، فإن في ذلك ترويح عن الروح، ومحاولة بث روح الأمل والطمأنينة في النفس، يقول الكندي:"ينبغي أن يكون منا على بال عند كل فائدة و معدوم، ما بقي لنا من قنياتنا الحسية و العقلية و أن نتشاغل بذكرها و تعديدها عن السالفة فإن في تذكر الباقي

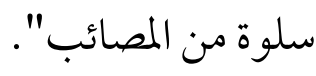
9 - إن الإنسان، من دون سائر الكائنات الحية، يريد اقتناء أشياء كثيرة 


\section{6}

ليست ضرورية في إقامة ذاته وصلاح عيشه، وإن جميع هذه الأشياء تسبب له الهم في طلبها، ومع كل فائت حسرة وأسف، ومع ترقب كل معدوم حزن وقلق ( ' ). ومن حكم الكندي: أن من ملك انفعالاته وتصرفاته ولم يهتم بالأشياء

الخارجة عنه، يملك ما يستعبد الملوك، ويستطيع أن يتغلب على قوى الشر في نفسه . نستطيع أن نقول وبكل جدارة، أن الكندي وهو أحد فلاسفة وحكماء المسلمين، قد امتاز في تحليل وتشخيص شعور الحزن، وتفوق في بيان أسبابه ودو افعه، وبرع في وضع العلاج وبيان طرق وأساليب الخلاص من هذا الانفعال. 


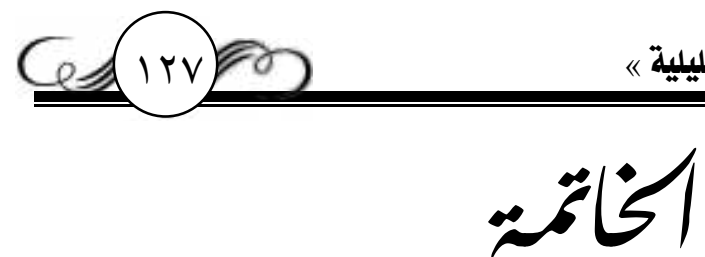

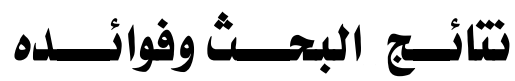

بعد عرض هذا الموضوع، ومعالجة قضاياه في ضوء وضوح الأفكار،

وتسلسلها وتر ابطها، فإنه يمكن التوصل إلى التتائج العامة التالية:

1 - الحزن شعور انفعالي، وعرض جبلي فطري ينتاب الإنسان عندما يغالب

$$
\text { صروف الحياة ومحنها . }
$$

r - يرد الحزن بمعاني خختلفة وحقول دلالية متنوعه، وهذه الحقول حسب قوتها وعمقها، وتأثيرها في النفس، من الأدنى إلى الأعلى، الحزن، البؤس، الأسى،

$$
\text { الغم، الكرب، الكمد، الكآبة، الهم، البث، الأسف. }
$$

r - إن حوافز وبواعث الحزن قد تكون مستقرة ومتوطنة أي: باطنية المنشأ وليس ها محفز ظاهر، وقد تكون خار جية ظاهرة ومحسوسة.

ع - لما كان الحزن من عوارض الطريق، وليس من مقامات الإيهان، ولا من منازل

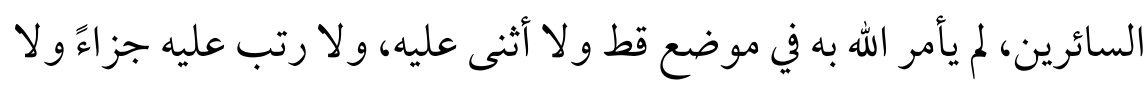
ثوابًا بل نهى عنه في غير موضع؛ وذلك لأنه لا يجلب منفعة ولا يدفع مضرة فلا فائدة ولا مصلحة فيه للقلب، فهو يضعفه، ولاشيء أحب إلى الشيطان من حزن المؤمن، ومالا فائدة ولا مصلحة فيه لا يأمر الله به، ولكن النهي 


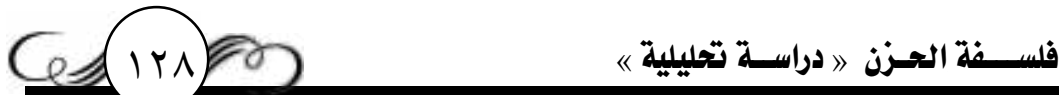

الوارد في الحزن ليس نهي تحريم؛ لكونه من عوارض الطبيعة البشرية، وخارج عن سلطان المرء، والشرع لا يكلف مالا يطاق، فلا يكون محرمًا ما دام مقتضاه صحيحًا.

ه - للحزن أعراض وجدانية، وأخرى ذهنية، وثالثة بدنية، أما الأعر اض الوجدانية فإن المصاب غالبًا ما ينعزل عن المجتمع ويلجأ إلى كهفه المظلم، لتلازمه الكآبة، وتفارقه السعادة والابتهاج، وفي هذه الحالة يغالبه الشعور بدنو الأجل، و الدخول في دائرة اليأس من رحمة الله، وعندها ينهال بالبكاء بدون أسباب ودواعي، وهذه المرحلة يسميها علماء النفس "بالاكتئاب" وهي

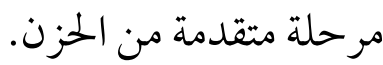

7 - أما الأعراض الذهنية، فشرود الذهن، وعدم التركيز، وسبق الوهم إلى العكس

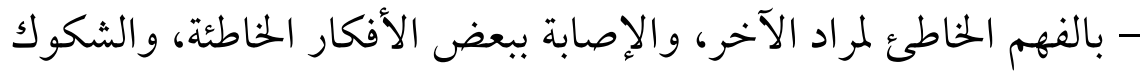
المرضية - وأبرز هذا النوع سيطرة النفس اللوامة عليه في كل صغيرة وكبيرة، وبدرجة شديدة تعوقه عن ممارسة حياته الاجتماعية.

V - أما الأعراض البدنية فأشدها وطئة على المصاب بالحزن، فقدان الشهية للطعام والشراب، ومن ثم الشعور بآلام متفرقة في الجسد، وفي هذه الحالة نجد طائفة من الناس تخلد إلى نوم عميق، وسباط طويل على غير الطبيعي، وكأن هذا الحزن يتفاعل مع البدن كتفاعل المواد الكيائية المهائة والمنومة والتي تثبط الجهاز العصبي المركزي، وطائفة أخرى يعانون من الأرق وعدم النوم، 


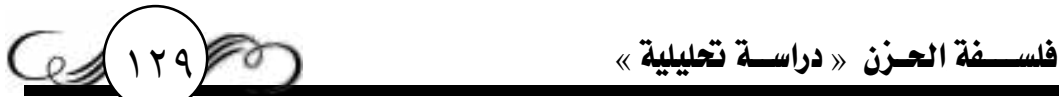

وكأن الحزن يعمل على إطلاق بعض المواد المنبه - من خلال الجهاز العصبي

$$
\text { والمخ - تؤدي بدورها إلى الإحساس باليقظة. }
$$

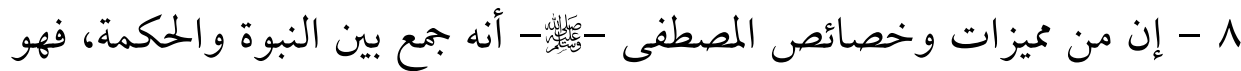
نبي طبيب، لهذا كان علاج الحزن في الإسلام بنوعين من الدواء:

الأول : معنوي روحي، وذلك بالنصح والإرشاد، ومحاولة رفع معنويات المصاب، وتقوية نفسه، بعبادات تبعث الطمأنينة في النفس، فينشرح الصدر ويأنس الفؤاد، وينفرج الهم والغم.

الثاني : ترياق حسي مادي له القدرة على إزالة الحزن والأسى، وتثبيت دعائم السرور والبهجة وهو الترياق النبوي المعروف باسم "التلبينة". 9 - إن علماء المسلمين أكثر براعة في تحليل شعور الحزن، ومعرفة أسبابه وأعراضه، وأنجح في اختيار الأساليب الفعالة في التغلب عليه وتخفيف وطأته.

النتيجة النهائية: الحزن من المشاعر السلبية، والانفعالات الضارة التي تؤثر على حياة الإنسان، له أسباب وأعراض، لا يستحسنه الإسلام، وللشرع الشريف دور فعَّال في علاجه من خلال نصوص الوحي الشريف، فلها بالغ الأثر على مشاعر الإنسان ونفسيته، وتعديل سلو كه. 


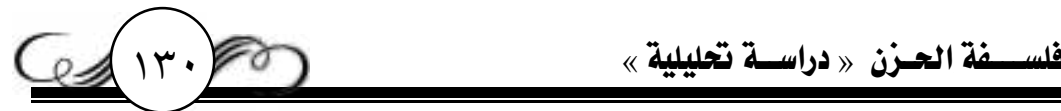

\section{فهـرس المراجسيع والمصـادر}

-1 -

1 - إحياء علوم الدين، الإمام/ أبي حامدمحد بن محمد بن محمد بن

أحمد الغزالي الطوسي النيسابوري الفقيه الصوفي الشافعي (المتوفي

$$
\text { سنة ه 0هـ) دار المعرفة، بيروت- لبنان. }
$$

r - الاستيعاب في معرفة الأصحاب، الإمام/ يوسف بن عبد الله بن محمد بن

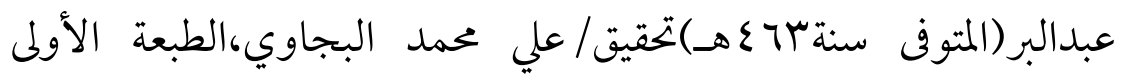

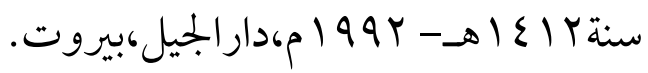

r - الإصابة في تمييز الصحابة،الإمام/ أحمد بن على بن حجر أبو الفضل العسقلانى

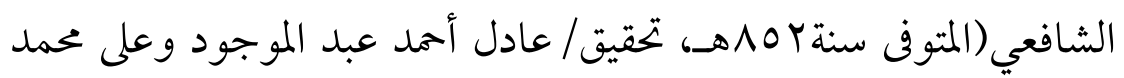
معوض،الطبعة الأولى سنة 1 ـ ا هـ،دار الكتب العلمية،بيروت - لبنان. ع - الأعلام، خير الدين بن محمود بن محمد الزركلي(المتوفى سنةه7ب اهــ) الطبعة

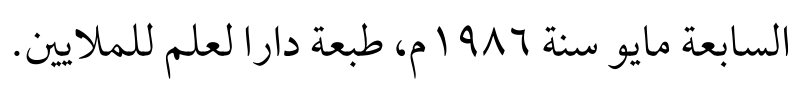

ه - أعلام الفكر الإسلامي، الدكتور / عثمان أمين، طبعة ستة (99 (م، دار الثقافة للنشر والتوزيح.

7 - إغاثة اللهفان في مصايد الشيطان الإمام/ أبي عبد الله محمد بن أبي بكر بن أيوب ابن قيم الجوزية (المتوفي سنة/V0هـ) تحقيق/ ححمد عزير شمس، الطبعة الأولى سنة بrع أهـ، دار عالم الفو ائد، مكة المكرمة. 


\section{Genting}

V - أمر اض القلوب وشفاؤها، شيخ الإسلام / تقي الدين أبى العباس أحمد بن

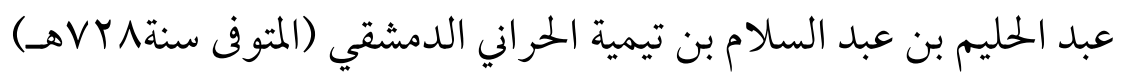
الطبعة الثانية سنة 99 1 1 اهــ، المطبعة السلفية، القاهرة.

1 - أيسر التفاسير لكلام العلي الكبير،جابر بن موسى بن عبد القادر أبو بكر

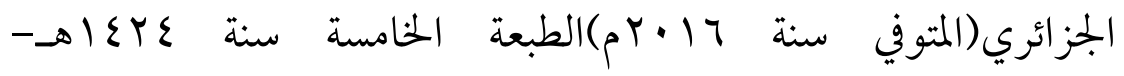

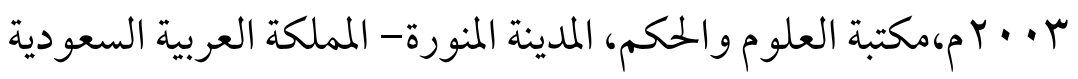

$$
\text { - }
$$

9 - بحر العلوم،الإمام/ علي بن يميى علاء الدين السمرقندي القرماني (المتوفى سنة

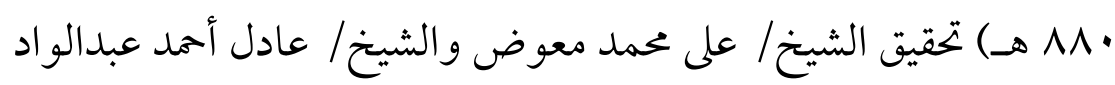

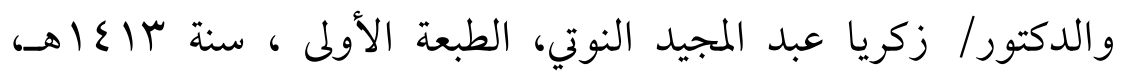
ب99 (99م، دار الكتب العلمية، بيروت - لبنان .

• - 1 - البداية والنهاية، الإمام/ أبى الفداء إسماعيل بن عمر بن كثير

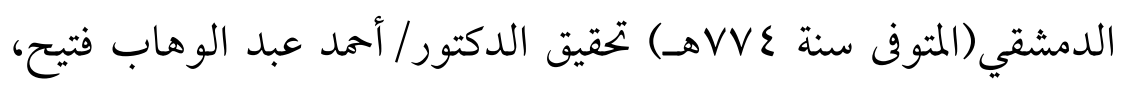

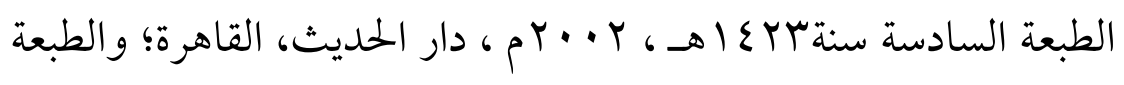
الأولى سنة 1 •عا (هـ- 911 (م، دار إحياء التراث العربي، تحقيق/ علي شيري. -

11 - تاج العروس من جواهر القاموس، للعلامة محمّد بن محمّد بن عبد الرزّاق 


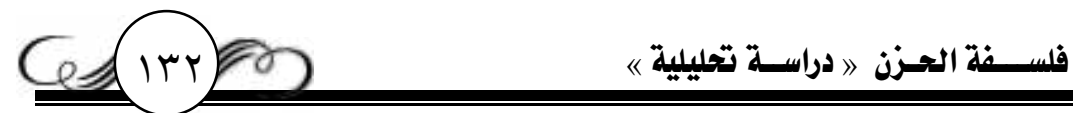

الحسيني، أبو الفيض، الملقّب بمرتضى الزَّبيدي(المتوفى سنة ه. ماهـ) تحقيق مجموعة من المحققين، طبعة دار الهداية.

rا - تاريخ الإسلام وَوَفيات المشاهير وَالأعلام الإمام / أحمد بن عتيق بن الحسن بن زياد بن فرج أبو جعفر المعروف بالذهبي (المتوفى سنة ا •7 هـ)، تحقيق الدكتور/بشار عوّاد معروف، الطبعة الأولى سنةب+..بم، دار الغرب

$$
\text { الإسلامي }
$$

با - تذكرة الحفاظ، الإمام / أحمد بن عتيق بن الحسن بن زياد بن فرج أبو جعفر المعروف بالذهبي (المتوفى سنة ل • 7 هـ) دار إحياء التراث العربي، بيروت ،

$$
\text { لبنان. }
$$

ع ا - تذكرة الموضوعات، محمد طاهر بن علي الصديقي الهندي الفَتَّيَي (المتوفى سنة 719هـ) ، الطبعة الأولى سنة بـ باهـ إدارة الطباعة المنيرية

10 - تاريخ الأستاذ الإمام الشيخ/ محمد عبده، السيد محمد رشيد رضا، طبعة سنة ع ب آهـ، مطبعة المنار .

17 - تاريخ بغداد، المؤرخ/ أحمد بن علي بن ثابت البغدادي، أبو بكر، المعروف بالخطيب (المتوفي سنة ساحگهـ) تحقيق الدكتور/ بشار عواد معروف، الطبعة الأولى سنة r ع ا - 1 + . r م، دار الغرب الإسلامي، بيروت- لبنان IV 
Ge العلا (المتوفى سنة بـ اهـ) دار الكتب العلمية، بيروت.

11 - التخلص من الاكتئاب، دوك تشيلدر، د. ديبورا وزمان، ترجمة/ عبير

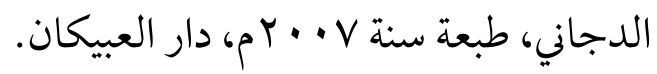

19 - التصوف، ماسينيون ومصطفى عبدالرازق، الطبعة الأولى سنة ع 9 (ام، دار

$$
\text { الكتاب اللبناني، بيروت - لبنان. }
$$

• · - التعريفات، الإمام/علي بن محمد بن علي المعروف بالشريف الجرجاني (المتوفى

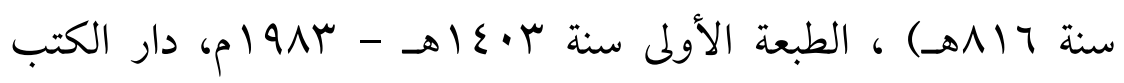

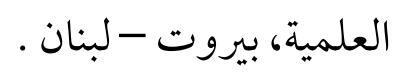

ا Y - تفسير المنار، العلامة/ عممد رشيد رضا، طبعة سنة •991م، الهيئة المصرية

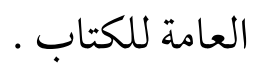

Y T - التفسير الوسيط للقرآن الكريم، الإمام الأستاذ الدكتور/ محمد سيد

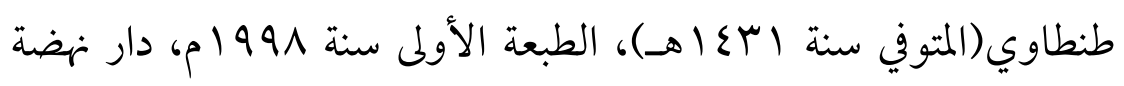

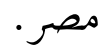

r ب - التمثيل والمحاضرة، عبد الملك بن محمد بن إسماعيل المعروف بأبي منصور

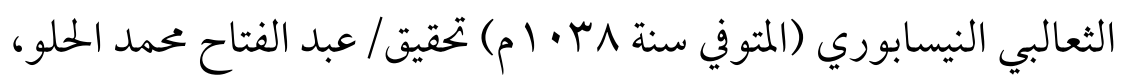
الطبعة الثانية سنة ا • ع اهـ - 1911 (م) الدار العربية للكتاب. ع - تهذيب الأخلاق وتطهير الأعراق، العلامة/ أبو علي أحمد بن محمد بن 


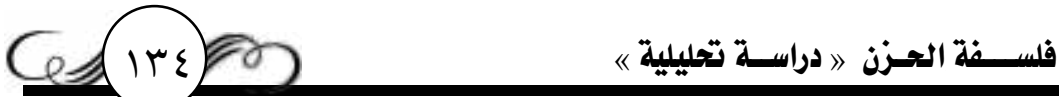

يعقوب الملقب بـابن مسكويه (المتوفى سنة •ب · |م ) تحقيق / عهاد الهلالي، الطبعة الأولى سنة 1 ا • بم ، منشورات الجمل ، بيروت - لبنان .

O Y - تهذيب الكمال، الإمام/ يوسف بن عبد الرحمن بن يوسف، أبو الحجاج، جمال الدين ابن الزكي أبي محمد القضاعي الكلبي ( المتوفى سنة rعهـ ) المعروف بـالمزي ، تحقيق الدكتور / بشار عو اد معروف ،الطبعة الرابعة سنة

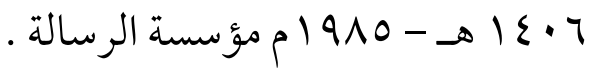
Tr - التوقيف على مهات التعاريف، العلامة/ محمد عبد الرؤوف بن تاج العارفين ابن علي بن زين العابدين الحدادي ثم المناوي القاهري، المشهور بالمناوي (المتوفى سنة اب + اهـ) الطبعة الأولى سنة · إع اهـ - - 99 ( م، دار عالم الكتب، القاهرة - مصر. rV - تيسير الكريم الرحمن في تفسير كلام المنان، عبد الرحمن بن ناصر بن عبد الله السعدي (المتوفى سنة7VI/هـ) تحقيق/عبد الرحمن بن معلا اللويكق،

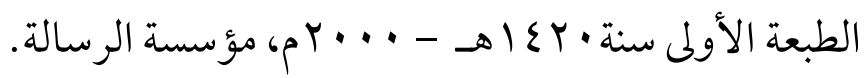

N Y - الداء والدواء، الإمام/ أبي عبد الله محمد بن أبي بكر بن أيوب ابن قيم الجوزية (المتوفى سنة V0 هـ) تمقيت/ ححمد أجمل الإصلاحي، الطبعة الأولى سنة

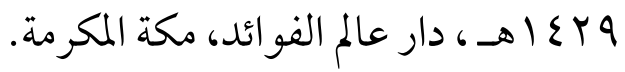
و - دفع إيهام الاضطراب عن آيات الكتاب، محمد الأمين بن محمد المختار بن 


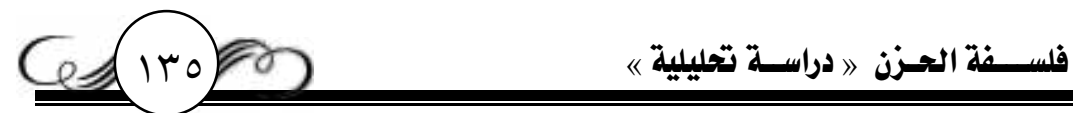

عبد القادر الجكني الشنقيطي (المتوفى سنة به باهـ) الطبعة الأولى سنة IV

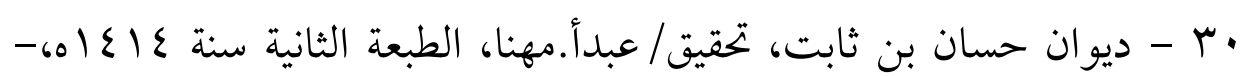

$$
\text { اب - ديو ان الخنساء، المكتبة الثقافية، بيروت - لبنان. } 99 \text { م، دار الكتب العلمية، بيروت- لبنان. }
$$

Y Y - ديو ان الخنساء "شرح ثعلب، تحقيق الدكتور / أنور أبو سويلم، الطبعة الأولى

$$
\text { ينة } 9 \text { • ع (هـ-19 (1) (م، دار عمار، الأردن-عمان. }
$$

بr - ديوان العجاج، رواية عبدالملك بن قريب الأصمعي، تحقيق الدكتور/عزة

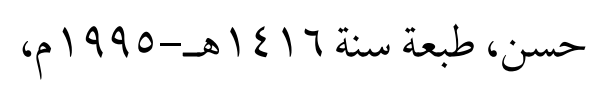

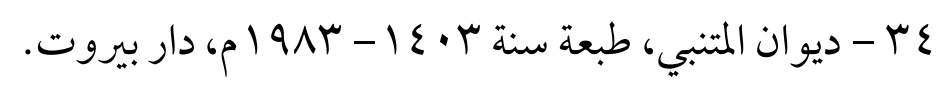

هr - ديوان النابغة الذبياني، تحقيق/ عحمد أبو الفضل إبراهيم، الطبعة الثانية، دار

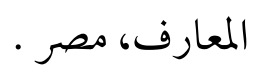

$$
-j-
$$

Tr - زاد المعاد في هدي خير العباد، الإمام/ أبي عبد الله محمد بن أبي بكر بن أيوب ابن قيم الجوزية (المتوفى سنة الولهـ) الطبعة السابعة والعشرون سنة 1 إهـ - ع 199 م، مؤسسة الرسالة، بيروت ومكتبة المنار الإسلامية، 


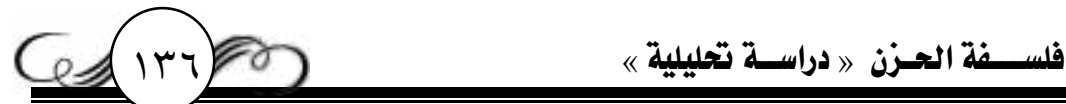

$$
-\jmath-
$$

V V - الرسالة القشيرية، عبد الكريم بن هوازن بن عبد الملك القشيري (المتوفى سنة 70ءهـ) تحقيق الإمام/ الدكتور عبد الحليم محمود والدكتور محمود بن الشريف، دار المعارف، القاهرة.

^ץ - رسالة الكندي" في الحيلة لدفع الحزن" ضمن رسائل فلسفية، جمع وتحقيق/ عبد الرحمن بدوي، الطبعة الثالثة سنة سم9 امه، دار الأندلس، بيروت لبنان.

\section{-}

هץ - جامع البيان في تأويل القرآن، الإمام أبى جعفر محمد بن جرير الطبري(المتوفى

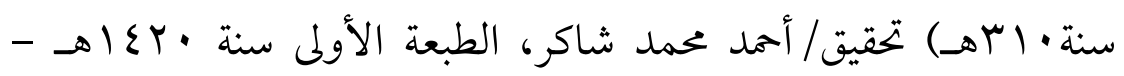

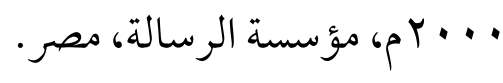
• ع - جمع الجو امع المعروف بالجامع الكبير، العلامة/ جلال الدين عبد الرحمن بن

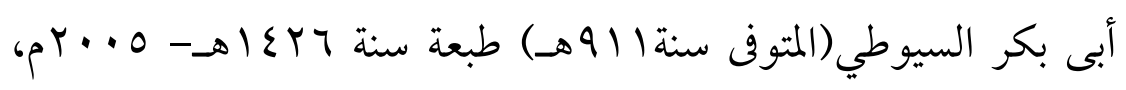
الطبعة الأزهرية، دار السعادة، مصر.

اع - جامع الأصول في الأولياء"الطرق الصوفية"، أحمد بن مصطفى ضياء الدين الكمشخانوي الحنفي النقشبندي الخالدي (المتوفى سنة | اساهـ) تحقيق/ اديب نصر الدين، الطبعة الأولى سنة $99 V$ (م، مؤسسة الانتشار العربي،

$$
\text { بيروت - لبنان. }
$$




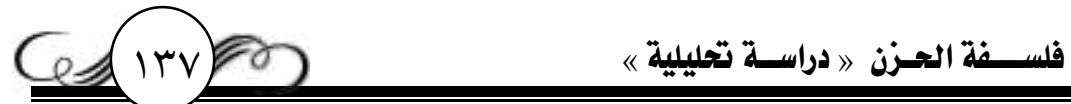

\section{$-\tau^{-}$}

Y Y - حاشية العلامة مصطفى العروسي المسماة: نتائج الأفكار القدسية في بيان

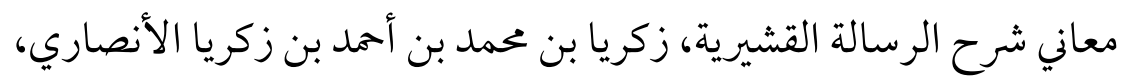

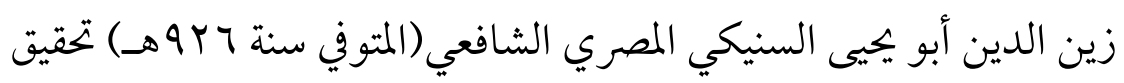
الشيخ/ عبدالوارث محمد علي، دار الكتب العلمية، بيروت-لبنان. بـ - الحزن الخبيث، لويس ولبرت، ترجمة/ عبلة عودة، مراجعة د/ أحمد خريس، الطبعة الأولى سنة مبع اهـ-ع ا • Yمههيئة أبو ظبي للسياحة والثقافة،

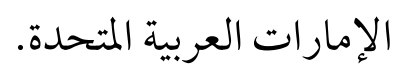

ع - الحزن والاكتئاب يؤديان إلى موت خلايا الدماغ " الدكتور/ مانيو وافي،

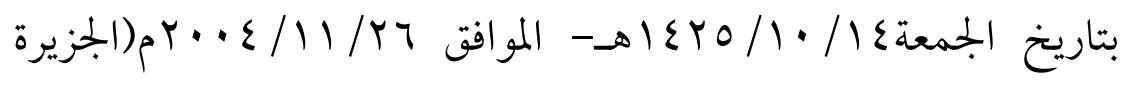
نت: Www.aljazeera.net).

0ـ - حلية الأولياء وطبقات الأصفياء، أبو نعيم أحمد بن عبد الله بن إسحاق بن

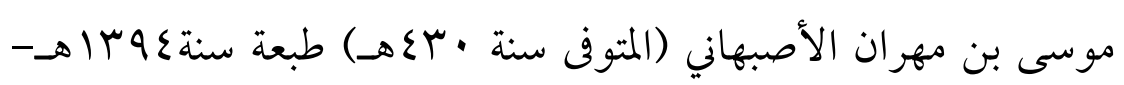
ع ع ال عم، دار السعادة، مصر.

\section{-س-}

7 - سلسلة الأحاديث الصحيحة وشيء من فقهها وفو ائدها، محمد بن الحاج نوح بن نجاتي بن آدم الأشقودري الألباني الأرناؤوط المعروف باسم محمد

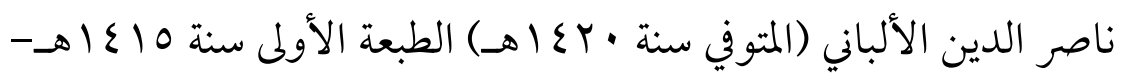




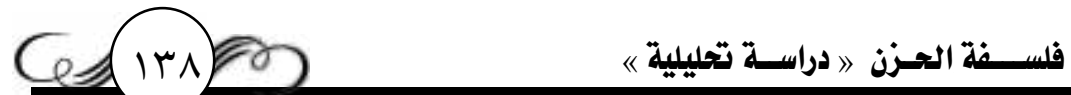

(990 190 مكتبة المعارف، الرياض.

ع V - سنن الترمذي،، الإمام/ أبو عيسى محمد بن عيسى الترمذي (المتوفى سنه

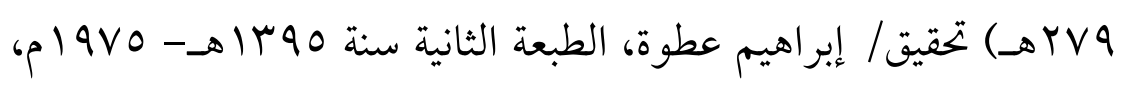
طبعة الحلبي، مصر.

^ع - سيرة أعلام النبلاء، الإمام/ عحمد بن أحمد بن عثمان بن قايهاز الذهبي أبو عبد الله (المتوفى سنةA ع Vهـ) تحقيق شعيب الأرناؤوط ومحمد نعيم العرقوسى،

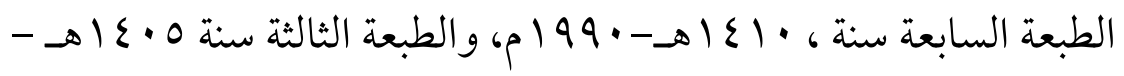

$$
\begin{aligned}
& \text { 1910 1 م، مؤسسة الرسالة، بيروت - لبنان. } \\
& \text { - ش - }
\end{aligned}
$$

9ع - شرح رياض الصالحين، محمد بن صالح بن محمد العثيمين (المتوفى سنة

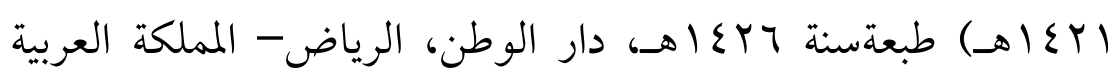
السعودية.

•0 - شرح الكتاب المقدس - العهد الجديد - القمص تادرس يعقوب ملطي، .http://st-takla.org

10 الغنائم محمد الكاشاني أوالكاشي أو القاشاني (المتوفي سنة • سرام) تحقيق/ محسن بيداء فر، مؤسسة التاريخ العبي، ودار حواء.

r - شرح منازل السائرين، عبدالمعطي بن محمود بن عبد المعطي ابن عبد الخالق، 


\section{Gen}

ابن أبي الثناء اللخمي الاسكندري( المتوفي سنة ربا ه)، طبعة سنة ع 90 1 م، المعهد العالي الفرنسي للآثار الشرقية بالقاهرة.

ro - شرح منازل السائرين، محمود بن حسن الفركاوي القادري، طبعة سنة به 90 م، المعهد العالي الفرنسي للآثار الشرقية بالقاهرة.

عه - شفاء العليل في مسائل القضاء والقدر و الحكمة والتعليل، الإمام/ أبي عبد الله

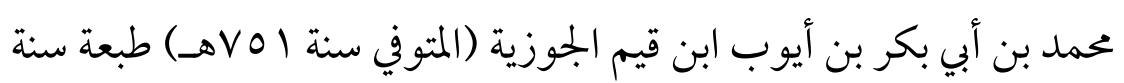

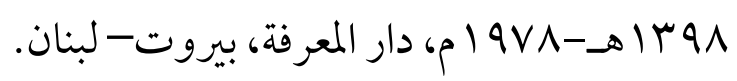

\section{-}

0 ه - الصحاح في اللغة، العلامة/ أبو نصر إسماعيل بن حماد الجوهري (المتوفى سنة

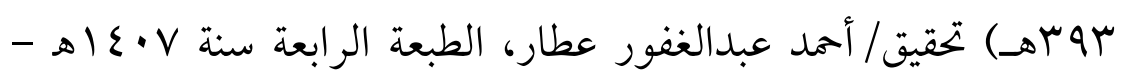
191v 1 19، طبعة دار العلم للملايين - بيروت.

7ه - صحيح البخاري، الإمام/ أبى عبد الله محمد بن إسماعيل البخاري (المتوفى

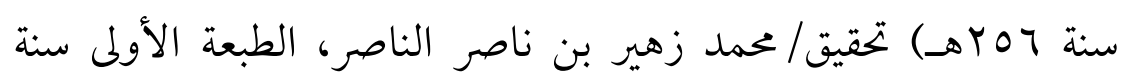
r r اع اهـ ، دار طوق النجاة .

OV - صحيح مسلم، الإمام/ أبو الحسين مسلم بن الحجاج القشيري النيسابوري (المتوفى سنة الrابهـ) تحقيق/ محمد فؤاد عبد الباقي، دار إحياء التراث

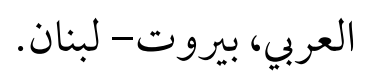




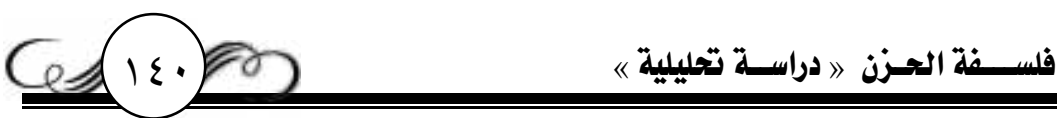

ه - صفة الصفوة، الإمام/ جمال الدين أبو الفرج عبد الرحن بن علي بن عمد الجوزي (المتوفى سنة 09Vهـ) تحقيق/ أحمد بن علي، طبعة سنة البع اهـ /

$$
\begin{aligned}
& \text {.... . . بم ، دار الحديث، القاهرة- مصر. } \\
& -b-
\end{aligned}
$$

هه - طبقات الأولياء، ابن الملقن سراج الدين أبو حفص عمر بن علي بن أحمد الشافعي المصري (المتوفى سنة ع ·ـهـ)شحقيق/ نور الدين شريبه، الطبعة الثانية سنة 0 إع (هـ- ع 99 ( م، مكتبة الخانجي، بالقاهرة • 7 - طبقات الصوفية،محمد بن الحسين بن موسى بن خالد بن سالم النيسابوري،السلمي(المتوفى سنة r اعهـ) تحقيق/مصطفى عبد القادر عطا، الطبعة الأولى سنة 19 (19 1991 ام، دار الكتب العلمية، بيروت- لبنان؛ وطبعة الشعب، تحقيق/ أحمد الشرباصي، الطبعة الثانية سنة

$$
\text { . } 1991-\infty 1 \leqslant 19
$$

الج - الطبقات الكبرى، عبد الوهّاب بن أحمد بن علي الأنصاري المشهور بـالشعراني (المتوفي سنة بوهـ) طبعة سنة 0 آباهـ ، المطبعة العامرة، مصر

r7 - طبقات المفسرين، أحمد بن محمد الأدنهوي(المتوفى في القرن الهـ) تحقيق/ سليمان بن صالح الخزي، الطبعة الأولى سنة IV أهـ- $99 V$ امب، مكتبة العلوم والحلكم، المملكة العربية السعودية. 


\section{Cesis}

rا7 - الطب من الكتاب والسنة، عبد اللطيف بن يوسف بن محمد بن أبي سعد

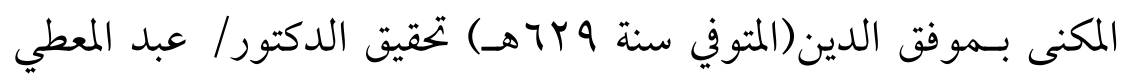

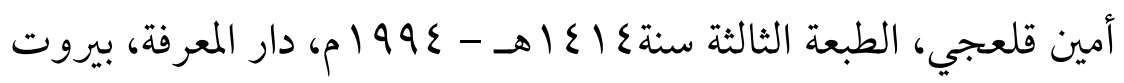
لبنان.

ع7 - الطب النبوي، أبو نعيم أحمد بن عبد الله بن أحمد بن إسحاق بن موسى بن

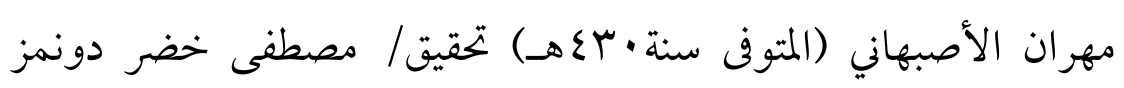
التركي، الطبعة الأولى سنة ج + . Tم، دار ابن حزم. 70 - طريق الهجرتين وباب السعادتين، الإمام/ شمس الدين محمد بن أبى بكر بن

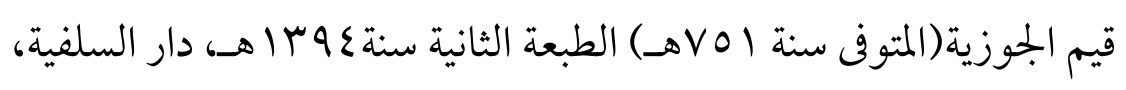

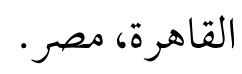

\section{$-\varepsilon-$}

77 - العين،العلامة/ الخليل بن أحمد بن عمرو بن تميم الفراهيدي الأزدي

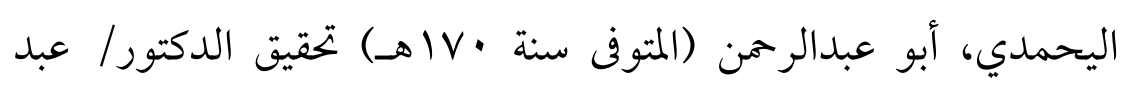

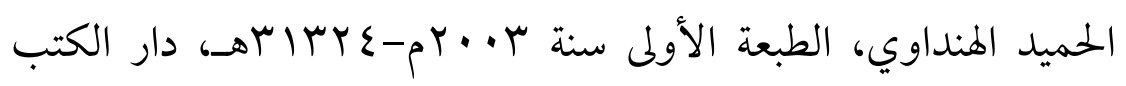

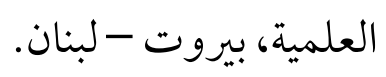
$-\dot{\varepsilon}-$

TV

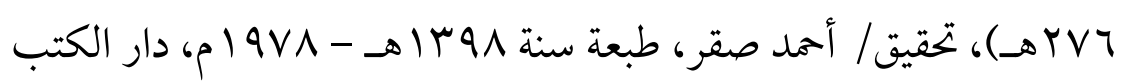


فلســة الحـزن 》 دراسـة تحليلية 《)

$$
\text { العلمية، بيروت - لبنان. }
$$

$$
-\dot{0}-
$$

11 - فتح الباري شرح صحيح البخاري، الإمام الحافظ/ أحمد بن على بن محمد الكناني العسقاني الشافعي، أبو الفضل شهاب الدين المعروف بابن حجر(المتوفى سنة 10rهـ) تحقيق/ محمد فؤاد عبد الباقي ومحب الدين

$$
\text { الخطيب، طبعة سنة ITV9 اهـ، دار المعرفة، بيروت - لبنان. }
$$

99 - الفتوحات المكية، محي الدين محمد بن علي بن محمد بن عربي الحاتمي الطائي الأندلسي(المتوفي سنة ^باجهـ)تحقيق/أحمد شمس الدين، الطبعة الأولى

$$
\text { سنة • بع اهـ - } 999 \text { | (م، دار الكتب العلمية، بيروت - لبنان. }
$$

• V - الفروق اللغوية، الأديب/ الحسن بن عبد الله بن سهل بن سعيد بن يكيى بن مهر ان العسكري، أبو هلال (المتوفي بعد سنة 9 سهـ) تحقيق/ محمد إبراهيم سليم، دار العلم و الثقافة، مصر. V - الفوائد المجموعة في الأحاديث الموضوعة، محمد بن علي بن محمد الشوكاني (المتوفى سنة • ب أهـ) تحقيت/عبد الرحمن بن يجي المعلمي اليماني، دار

$$
\text { الكتب العلمية، بيروت-لبنان. }
$$

VY - فوات الوفيات، محمد بن شاكر بن أحمد بن هارون، الملقب بصلاح الدين (المتوفى سنة \&VIهـ) تحقيق/ إحسان عباس، الطبعة الأولى سنة

$$
\text { ع } 9 \text { | ام،دار صادر،بيروت - لبنان }
$$




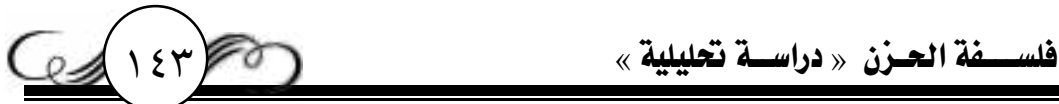

ع - في الباطن والظاهر المسمى "جلاء الخاطر" الشيخ/ أبو ححمد عبد القادر بن موسى بن عبد الله، المعروف بعبد القادر الجيلاني (المتوفي سنة ال70هـ) تحقيق/ خالد الزرعي وعبد الناصر سِرِي، الطبعة الأولى سنة ع99 أم، دار

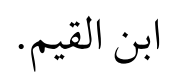

r V - فيض القدير شرح الجامع الصغير، زين الدين محمد عبد الرؤوف بن علي بن زين العابدين الحدادي ثم المناوي القاهري(المتوفى سنة ابـ اهـ)تحقيق/ أحمد عبد السلام، الطبعة الاولى سنة 0 اعاه- ع99 ام، دار الكتب

$$
\text { العلمية، بيروت- لبنان. }
$$

Vo - في ظلال القرآن سيد قطب إبراهيم حسين الشاربي (المتوفى سنة

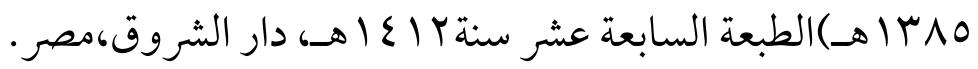

$$
\text { - }
$$

ق Vاموس الكتاب المقدس، تأليف/ نخبة من الأساتذة ذوى الاختصاص من اللاهوتين، الطبعة السادسة سنة 1911 ام، منشورات مكتبة المشعل،

$$
\text { بيروت، لبنان. }
$$

$$
-5-
$$

VV البقاء الحنفي (المتوفي سنة ع9 ·اهـ) تحقيق/عدنان درويش ومحمد المصري، طبعة سنة 9 1 ع اهـ - 991 (م، مؤسسة الرسالة، بيروت. 


\section{$-J-$}

VN - لسان العرب، العلامة/ أبى الفضل جمال الدين بن مكرم بن منظور الأفريقي

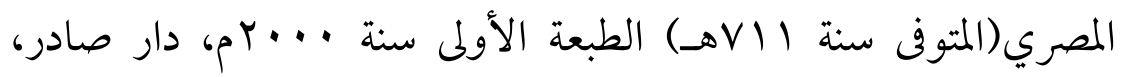

Vq - جمع بحار الأنوار في غرائب التنزيل ولطائف الأخبار، جمال الدين، محمد طاهر بن علي الصديقي الهندي الفَتَّي الكجراتي (المتوفى سنة

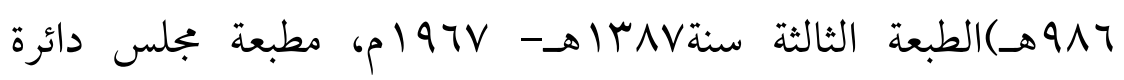

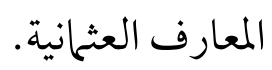

• 1 - بجموع الفتاوى، شيخ الإسلام / تقي الدين أبى العباس أحمد بن عبد الحليم

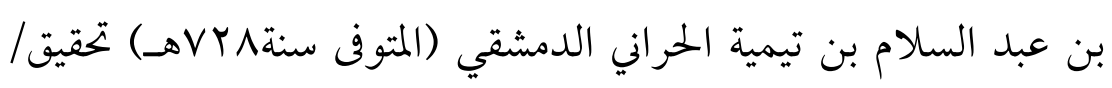

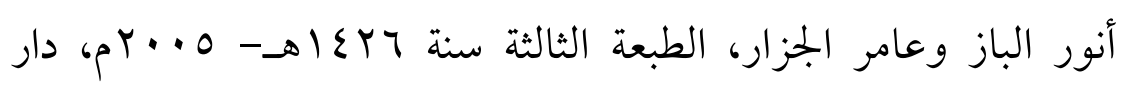
الوفاء.

1 - المحرر الوجيز في تفسير الكتاب العزيز، أبو محمد عبد الحقى بن غالب بن تمام

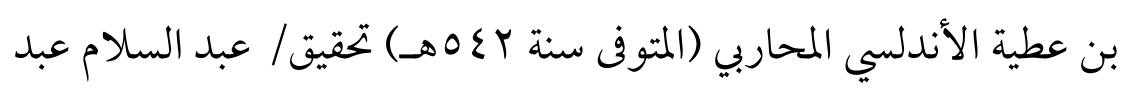
الشافي محمد، الطبعة الأولى سنة ب بع اهـ، دار الكتب العلمية، بيروت-

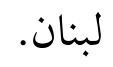

r 


\section{Ge.}

بالصاحب بن عباد (المتوفى سنة 1/10هـ) تحقيق/ عحمد حسن آل ياسين،

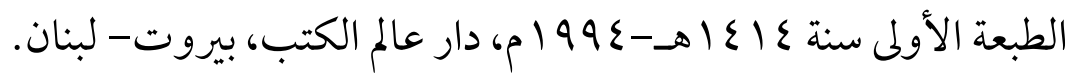
rی - غختار الصحاح، للإمام/ محمد الرازي فخر الدين بن العلامة، ضياء الدين عمر، المشتهر بخطيب الري(المتوفى سنة 7 77هـ) تحقيق/ يوسف الشيخ محمد، الطبعة الأولى سنة rاع اه، دار القلم، الدار الشامية، دمشقبيروت.

ع - مختصر الشمائل المحمدية، الإمام/ أبو عيسى محمد بن عيسى الترمذي

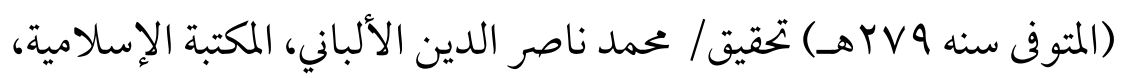

$$
\text { عان-الأردن. }
$$

10 - مدارج السالكين بين منازل إياك نعبد وإياك نستعين، الإمام/ شمس الدين محمد بن أبى بكر بن قيم الجوزية (المتوفى سنة اOVهـ) تحقيق/ محمد المعتصم باله البغدادي، الطبعة الثالثة سنة 17 (اهـ- 1997 1م، دار

$$
\text { الكتاب العربي، بيروت- لبنان. }
$$

1 - مدارك التنزيل وحقائق التأويل، الإمام/ أبو البركات عبد الله بن أحمد بن محمود النسفي (المتوفى سنة • الVهـ) تحقيق/يوسف علي بديوي، الطبعة الأولى سنة9 1 ع (هـ- 991 (م) دار الكلم الطيب، بيروت- لبنان.

AV المستدرك على الصحيحين، الإمام أبى عبد الله محمد النيسابوري المعروف بالحاكم (المتوفى سنةه •عهـ) تحقيق/ مصطفى عبد القادر عطا، الطبعة 


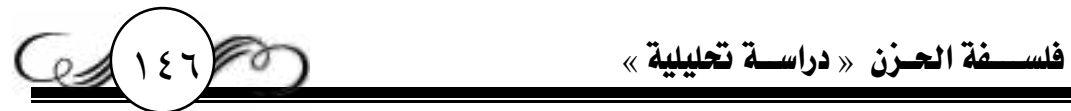

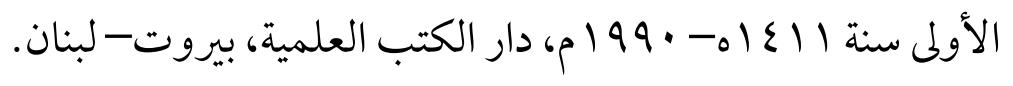

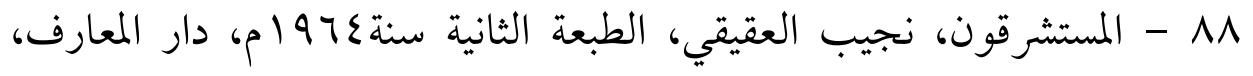

$$
\text { مصر }
$$

19 - المسند، الإمام/ أحمد بن حنبل أبو عبد الله الشيباني(المتوفى سنة اعـهـ) تحقيق/ شعيب الأرناؤوط، عادل مرشد وآخرون، الطبعة الأولى سنة

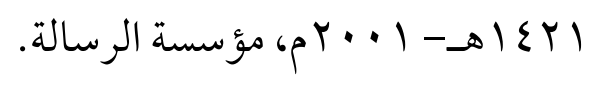

•9 - المسيح مشتهى الأجيال منظور أرثوذكسي، الأنبا/ بيشوى، الطبعة الثانية سنةV · · Fم، الناشر مطرانية دمياط وكفر الشيخ والبراري ودير القديسة

$$
\text { دميانة. }
$$

91 - معجم الحضارات السامية ،هنري. س. عَبّودي، الطبعة الثانية سنة

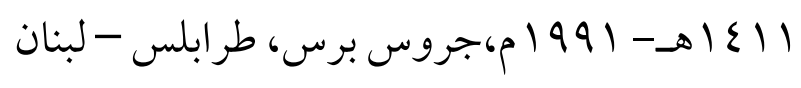

r 9 - معجم علم النفس والتربية،جمع اللغة العربية،طبعة سنة س + . بم، المطبعة

$$
\text { الأمرية، مصر }
$$

به - معجم الفلاسفة، جورج طر ابيشي،الطبعة الثالثة سنة ج · · rم، دار الطليعة،

$$
\text { بيروت - لبنان. }
$$

ع - المعجم الفلسفي، الدكتور / جميل صليبا، طبعة سنة ع إع اهـ - ع99 ام، الشركة العالمية للكتاب، بيروت - لبنان. 


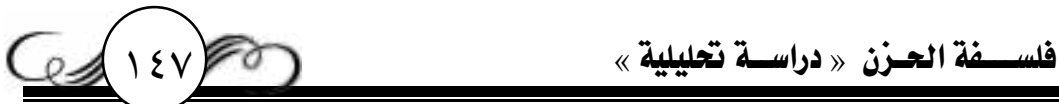

90 - المعجم الكبير، الإمام/ سليمان بن أحمد بن أيوب أبو القاسم الطبراني (المتوفي سنة · اسهـ) تحقيق/ محدي بن عبد المجيد السلفي، الطبعة الثانية، مكتبة

$$
\text { ابن تيمية - القاهرة. }
$$

97 - المعجم المفهرس لألفاظ القرآن الكريم، محمد فؤاد عبد الباقي، طبعة سنة ع عبا اهـ، دار الكتب المصرية.

9V

$$
\text { (المتوفى سنة 1 • ع اهـ) دار احياء التراث العربي، بيروت - لبنان. }
$$

هو - مفاتيح الغيب، الإمام/ محمد الرازي فخر الدين بن العلامة، ضياء الدين عمر، المشتهر بخطيب الري، (المتوفى سنة، 7 ·7هـ) الطبعة الأولى سنة

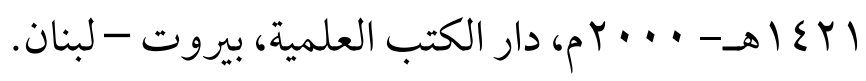

99 - المفردات في غريب القرآن، الإمام/أبو القاسم الحسين بن محمد المعروف بالراغب الأصفهاني (المتوفى سنة r ب.0ه) تحقيق /صفوان عدنان الداودي، الطبعة الأولى سنة ب إع أهـدار القلم والدار الشامية، بيروت -

$$
\text { لبنان }
$$

• . . - المفهم لما أشكل من تلخيص كتاب مسلم، أبو العباس أحمد بن عمر بن إبراهيم القرطبي(المتوفي سنة 707هـ) تحقيق الدكتور/عبد الهادي النازي،

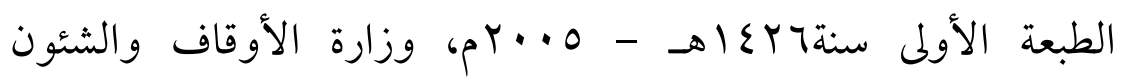

$$
\text { الإسلامية، الرباط - المغرب. }
$$




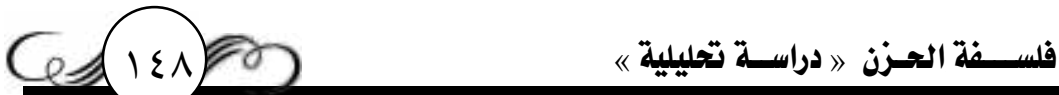

1 | 1 - مقايس اللغة،العلامة/ أبو الحسين أحمد بن فارس بن زكريا القزويني الرازي (المتوفي سنة هوب هـ) تحقيق/عبد السلام محمد هارون، طبعة سنة

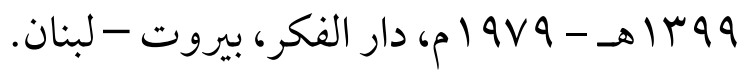

ץ • 1 - الملل والنحل، الإمام/ عحمد بن عبد الكريم بن أحمد أبو الفتح المعروف بالشهرستانى(المتوفى سنة/ \&ههـ ) تحقيق/ أمير على مهنا وعلى فاعور،

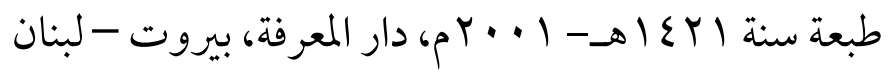

ب • 1 - منازل السائرين، الإمام/ أبو إسماعيل عبد الله بن محمد بن جعفر بن منصور الأنصاري الهروي (المتوفى سنة اگهــ) دار الكتب العلمية، بيروتلبنان.

ع • 1 - مناهج البحث العلمي، الدكتور / عبد الرحمن بدوى، طبعة سنة س7 9 (م، دار النهضة العربية، مصر. 0 • 1 - مناهج البحث الفلسفي، الدكتور / محمد أمد مصطفى السرياقوس، طبعة سنة 990 (م، دار الثقافة للنشر، القاهرة. 7 - 1 - مناهج البحث في علم النفس، الدكتور/ حلمي المليجي، الطبعة الأولى سنة

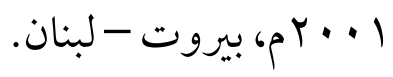

V • 1 - المنهاج شرح صحيح مسلم بن الحجاج، الإمام/ أبو زكريا يميى بن شرف

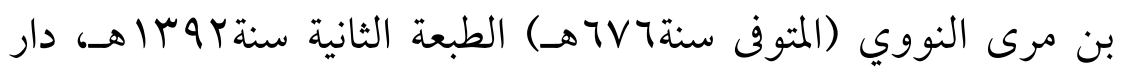




\section{6}

$$
\text { إحياء التراث العربي، بيروت-لبنان. }
$$

1 • 1 - منهاج السنة النبوية في نقض كلام الشيعة القدرية،شيخ الإسلام / تقي الدين أبى العباس أحمد بن عبد الحليم بن عبد السلام بن تيمية الحراني الدمشقي (المتوفى سنةمYVIهـ) تحقيق/ عممد رشاد سالم، الطبعة الأولى سنة

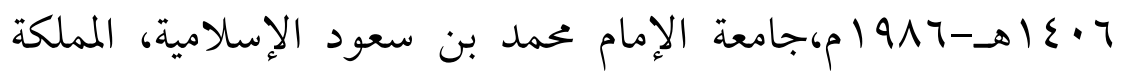
العربية السعودية.

9 • 1 - المواهب اللدنية بالمنح المحمدية، أمد بن ححمد بن أبى بكر بن عبد الملك القسطلاني القتيبي المصري، أبو العباس، شهاب الدين (المتوفى سنة بr (9هـ ) المكتبة التوفيقية، القاهرة- مصر. • 11 - الموسوعة الثقافية للأعلام، إشراف الدكتور/حسين سعيد، طبعة سنة 9 ا (م، طبعة دار الشعب.

111 - موسوعة الفلسفة، الدكتور/ عبد الرحمن بدوي(المتوفي سنة r +.بم) الطبعة الأولى سنةع 9 ا |م، المؤسسة العربية للدراسات والنشر

$$
-\dot{-}-
$$

Y| 11 - نزهة الألباء في طبقات الأدباء، عبد الرحمن بن محمد بن عبيد الله الأنصاري، أبو البركات، كهال الدين الأنباري(المتوفى سنة OVV تحقيق/ إبراهيم السامرائي، الطبعة الثالثة سنة ه • ع اهـ- 910 ( م، مكتبة

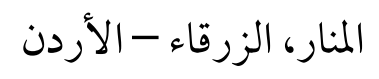


فلســة الحسزن 》 دراسـة تحليلية 《)

سا| - النهاية في غريب الحديث والأثر، الإمام/ شمس الدين أبو الخير ابن الجزري، محمد بن محمد بن يوسف (المتوفى سنةسبههـ) تحقيق/طاهر أحمد الزاوي، محمود محمد الطناحي، طبعة سنة99 باهـ-9V9 (م)، المكتبة

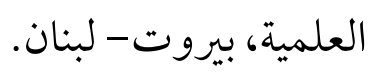$$
\text { - و- }
$$

ع || - وسائل الشيعة(آل البيت) أبو جعفر محمد بن الشيخ الحسن بن علي الحر العاملي (المتوفي سنة سب، 1 ه) تحقيق/مؤسسة آل البيت عليهم السلام لإحياء التراث، الطبعة الثانية سنة ع ا ع اهـ، مؤسسة آل البيت، قم- إيران. 110 - وفيات الأعيان، الإمام/ شمس الدين أبو العباس أحمد بن محمد بن إبراهيم بن أبى بكر بن خلكان الأربلى الشافعي(المتوفى سنة الجهـ) تحقيق/ إحسان عباس، الطبعة الأولى سنة · .91 (1م، دار صادر، بيروت لبنان. 


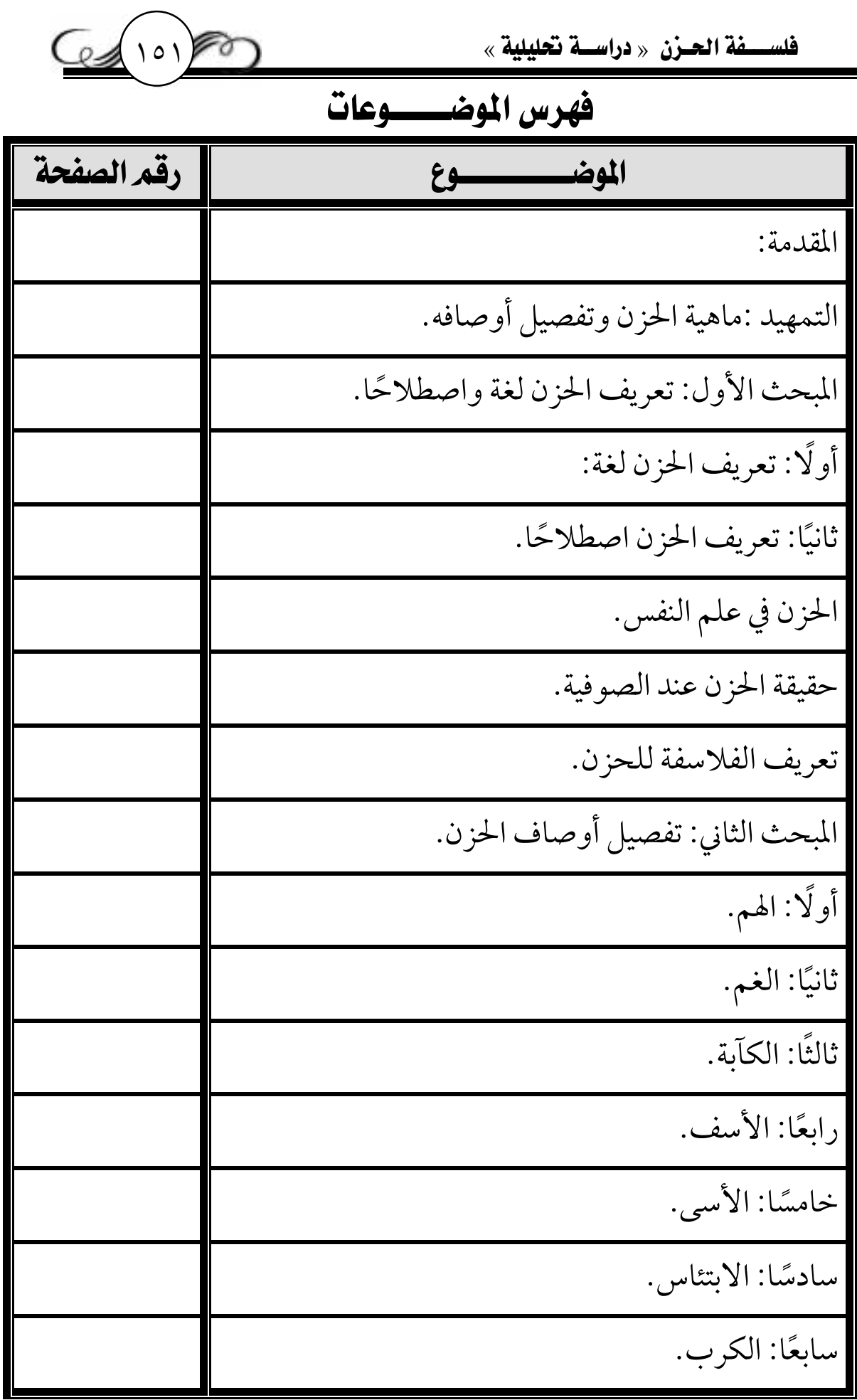




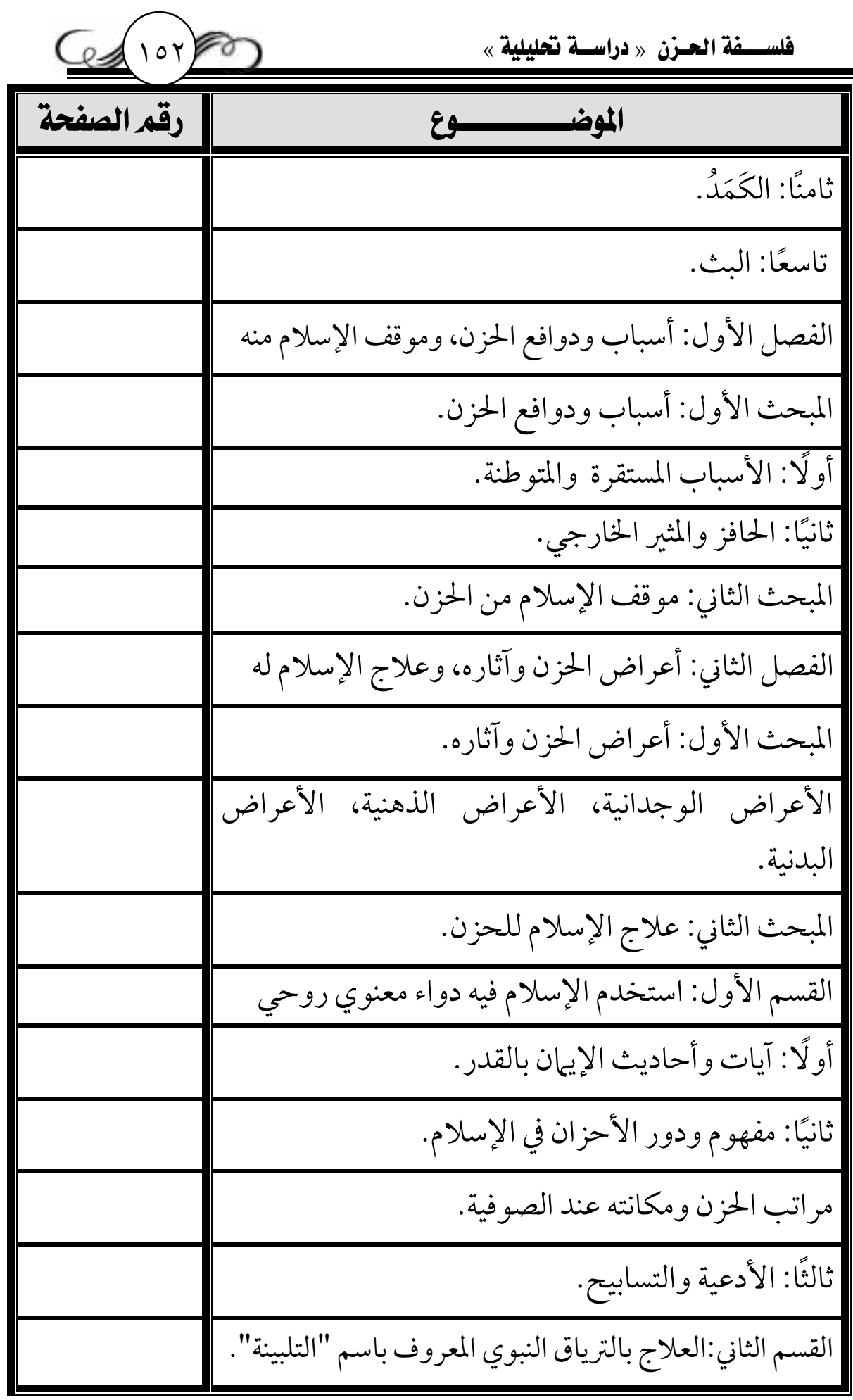




\begin{tabular}{|c|c|}
\hline رقم الصفحة & 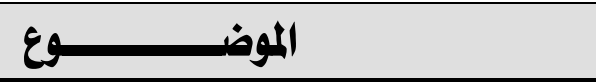 \\
\hline & تعقيب: نظرية الكندي في علاج الحزن. \\
\hline & الخاتمة: نتائج البحث وفو ائده. \\
\hline & فهرس المراجع والمصادر. \\
\hline & فهرس الموضوعات. \\
\hline
\end{tabular}

